\title{
SHRIMP $\mathrm{U}-\mathrm{Pb}$ zircon evidence for age, provenance, and tectonic history of early Paleozoic Ganderian rocks, east-central Maine, USA
}

\author{
Allan Ludman ${ }^{1 *}$, John AleinikofF ${ }^{2}$, Henry N. Berry IV³, And John T. Hopeck ${ }^{4}$ \\ 1. School of Earth and Environmental Sciences, Queens College (CUNY), Flushing, New York 11367, USA \\ 2. United States Geological Survey, MS 973, Denver, Colorado 80225, USA \\ 3. Maine Geological Survey, 93 State House Station, Augusta, Maine 04333, USA \\ 4 Maine Department of Environmental Protection, 17 State House Station, Augusta, Maine 04333, USA \\ *Corresponding author <allan.ludman@qc.cuny.edu>
}

Date received: 27 November 2017 gate accepted: 01 October 2018

\begin{abstract}
SHRIMP U-Pb zircon ages from Ganderia in eastern Maine clarify the ages and provenance of basement units in the Miramichi and St. Croix terranes and of cover rocks in the Fredericton trough and Central Maine/ Aroostook-Matapedia basin (CMAM). These new data constrain timing of orogenic events and help understand the origin of the cover rock depocenters.

Detrital zircon data generally confirm suggested ages of the formations sampled. Zircon grains with ages of ca. $430 \mathrm{Ma}$ in both depocenters, only slightly older than their host rocks, were probably derived from the earliest volcanic eruptions in the Eastport-Mascarene belt. Their presence indicates that unnamed CMAM sandstone units may be as young as Pridoli and their absence from the Appleton Ridge and Digdeguash formations suggests that these formations are older than initial Eastport-Mascarene volcanism. Detrital and volcanic zircon ages confirm a Late Cambrian to Middle Ordovician age for the Miramichi succession and date Miramichi volcanism at $469.3 \pm 4.6 \mathrm{Ma}$. In the St. Croix terrane, zircon grain with an age of $477.4 \pm 3.7 \mathrm{Ma}$ from an ashfall at the base of the Kendall Mountain Formation and age spectra and fossils from overlying quartz arenite suggest that the formation may span Floian to Sandbian time. The main source of CMAM and Fredericton sediment was recycled Ganderian basement from terranes emergent after Late Ordovician orogenesis, supplemented by Silurian tephra. Zircon barcodes and lithofacies and tectonic models suggest little, if any, input from Laurentia or Avalonia.

Zircon- and fossil-based ages indicate coeval Upper Ordovician deformation in the St. Croix (ca. 453 to $442 \mathrm{Ma}$ ) and Miramichi (ca. 453 to $446 \mathrm{Ma}$ ) terranes. Salinic folding in the southeastern Fredericton trough is bracketed between the $421.9 \pm 2.4 \mathrm{Ma}$ age of the Pocomoonshine gabbro-diorite and $430 \mathrm{Ma}$ detrital zircons in the Flume Ridge Formation. Zircon ages, lithofacies analysis, and paleontological evidence support the origin of the Fredericton trough as a Salinic foredeep. The CMAM basin cannot have been an Acadian foreland basin, as sedimentation began millions of years before Acadian subduction.
\end{abstract}

\section{RÉSUMÉ}

Le système de datation U-Pb sur zircon au moyen du SHRIMP de Ganderia dans lest du Maine clarifie la datation et la provenance d'unités souterraines des terranes de Miramichi et St. Croix et des rochers de la dépression de Frédéricton au bassin du centre du Maine et d'Aroostook-Matapédia (CMAM). Ces nouvelles données limitent léchelonnement des phénomènes orogéniques et facilitent la compréhension de l'origine des zones de dépôt du rocher.

Les données sur le zircon détritique confirment généralement la datation suggérée des formations échantillonnées. Les grains de zircon datant d’environ $430 \mathrm{Ma}$ dans les deux zones de dépôt, à peine plus anciens que leurs roches hôtes, provenaient probablement des premières éruptions volcaniques de la région d'EastportMascarene. Leur présence indique que les unités sans noms de grès du CMAM pourraient être aussi jeunes que Pridoli et leur absence des formations d'Appleton Ridge et Digdeguash suggère que ces formations sont plus anciennes que le volcanisme d'origine d'Eastport-Mascarene. La datation du zircon détritique et volcanique confirme lầge avancé du Cambrien au milieu de lâge du Ordovicien pour la succession de Miramichi et évalue l'âge du volcanisme de Miramichi à 469,3 \pm 4,6 Ma. Dans la terranne de St. Croix, le grain de zircon datant de $477,4 \pm 3,7 \mathrm{Ma}$ à partir d'une chute de cendre à la base de la formation de la Kendall Mountain et d'un spectre dầge et de fossiles aérnite de quartz superposé suggère que la formation traverse la période de Floian à Sandbian. La source principale de sédiment du CMAM et de Frédéricton provenait de recyclage souterrain de Ganderian à 
partir des terrannes émergentes à la suite de l’orogenèse tardive d’Ordovician, complétés par le tephra Silurien. Les codes à barres et lithofaciès de zircon et les modèles tectoniques suggèrent peu, voir aucune donnée de Laurentia ou d'Avalonia.

La datation selon le zircon et le fossile indique le même âge que la déformation de l'Ordovicien supérieur dans les terrannes de St. Croix (environ de 453 à $442 \mathrm{Ma}$ ) et Miramichi (environ de 453 à $446 \mathrm{Ma}$ ). Le pli salinique au sud-est de la dépression de Frédéricton se trouve dans une fourchette d'âge entre lâge du gabbro-diorite de Pocomoonshine 421,9 $\pm 2,4 \mathrm{Ma}$ et $430 \mathrm{Ma}$ de zircons détritiques dans la Formation de Flume Ridge. La datation du zircon, les analyses de lithofaciès et les preuves paléontologiques soutiennent lorigine de la dépression de Frédéricton en tant qu'avant-fosse salinique. Le bassin du CMAM ne peut pas avoir été un bassin d'avant-pays acadien puisque la sédimentation a commencé des millions d’années avant la subduction acadienne.

\section{[Traduit par la redaction]}

\section{INTRODUCTION}

This study was undertaken to address problematic stratigraphic and tectonic interpretations in east-central and eastern Maine that could not be resolved by mapping and lithofacies analysis. The goals of this study are to use ages of detrital, volcanic, and plutonic zircon to (1) constrain the stratigraphic ages of mostly unfossiliferous sandstone units from the Fredericton trough and Central Maine/AroostookMatapedia (CMAM) depocenters (Fig. 1); (2) determine whether the sediment in these basins was derived from sources external to Ganderia, i.e., Laurentia and/or Avalonia (Fig. 2); and (3) date Cambrian-Ordovician strata in the Miramichi and St. Croix terranes. It was anticipated that detrital zircon age spectra might provide a distinctive Ganderian "signature" useful for distinguishing the terrane in southern New England. New age data are reported for Silurian sedimentary rocks of the CMAM basin and Fredericton trough, and pre-Silurian sedimentary and volcanic rocks from the St. Croix and Miramichi Ganderian "basement" terranes.

\section{Tectonic framework}

A complex tectonic evolution spanning the entire Appalachian Wilson cycle has been interpreted in the northern Appalachian orogen (Table 1), punctuated by several orogenic events as the microcontinental plates Ganderia, Avalonia, and Meguma (Fig. 2) were rifted from Gondwana and progressively accreted to Laurentia (ancestral North America). Today, Ganderia is a major terrane in the orogen that reaches its maximum width where it underlies most of Maine and New Brunswick (Fig. 2). It is floored by Late Neoproterozoic to Early Cambrian crust that detached from Gondwana in the Early Cambrian, at which time it was separated by the Iapetus Ocean from Laurentia. Subduction of Iapetan lithosphere beneath the leading edge of Ganderia created the Popelogan arc and associated Tetagouche backarc basin of the Miramichi terrane (Fig. 1), separating the leading (northwestern in current geography) and trailing components of Ganderia. These components were reunited during the Penobscot orogeny, and the Popelogan arc collided with Laurentia in the Late Ordovician, closing the main body of Iapetus. Closure of a back-arc basin at the trailing edge of Ganderia (St. Croix terrane) during the Salinic orog- eny completed the accretion of Ganderia to Laurentia.

Emergent highlands composed of Ganderian basement rocks supplied sediment to the adjacent Fredericton and CMAM depocenters from the Late Ordovician through Late Silurian (Ludman et al. 2017). These sedimentary rocks were subsequently folded during the Salinic orogeny, and again during Early Devonian (Acadian) accretion of Avalonia (Fyffe et al. 2011). This paper focuses mostly on rocks deposited between the Penobscot and Acadian orogenies, but also examines some of the Miramichi and St. Croix source rocks whose ages have previously been uncertain.

\section{Geologic setting}

Precambrian to mid-Ordovician Ganderian arc and back-arc rocks are exposed in Maine and New Brunswick as small inliers and extensive northeast-trending belts separated by thick Late Ordovician to Silurian or Devonian turbiditic rocks (Fig. 1). The Middle Ordovician and older rocks will be referred to in this paper as "basement" and Late Ordovician and younger rocks as "cover". The thick turbidite successions that today isolate the older belts at the surface and obscure their subsurface relationships are generally ascribed to the Fredericton trough and the Central Maine and Aroostook-Matapedia basins, recognized by Ludman et al. (2017) as a single Central Maine/Aroostook-Matapedia (CMAM) depocenter (Fig. 1).

Age and relationship among cover sandstone units have been problematic for many years because of sparse bedrock exposures and similar lithologies and bedding styles, lack of distinctive marker horizons, and extremely rare fossil age control. Lithofacies and paleocurrent analyses indicate deposition in two distinct sedimentary regimes: a Late Ordovician to Late Silurian phase in which several emergent pre-Silurian belts shed sediment locally into the adjacent basins (Ludman et al. 2017), and a Late Silurian to Middle Devonian regime in which sandstones deposited in a NW-migrating Acadian foreland basin swamped the original source areas with sediment from a single eastern source (Bradley et al. 2000; Bradley and O'Sullivan 2016).

The study area outlined in Figure 3 spans much of eastern and east-central Maine, a region blanketed by thick glacial deposits and characterized by less than $1 \%$ bedrock exposure. Most basement and cover rocks experienced lower 


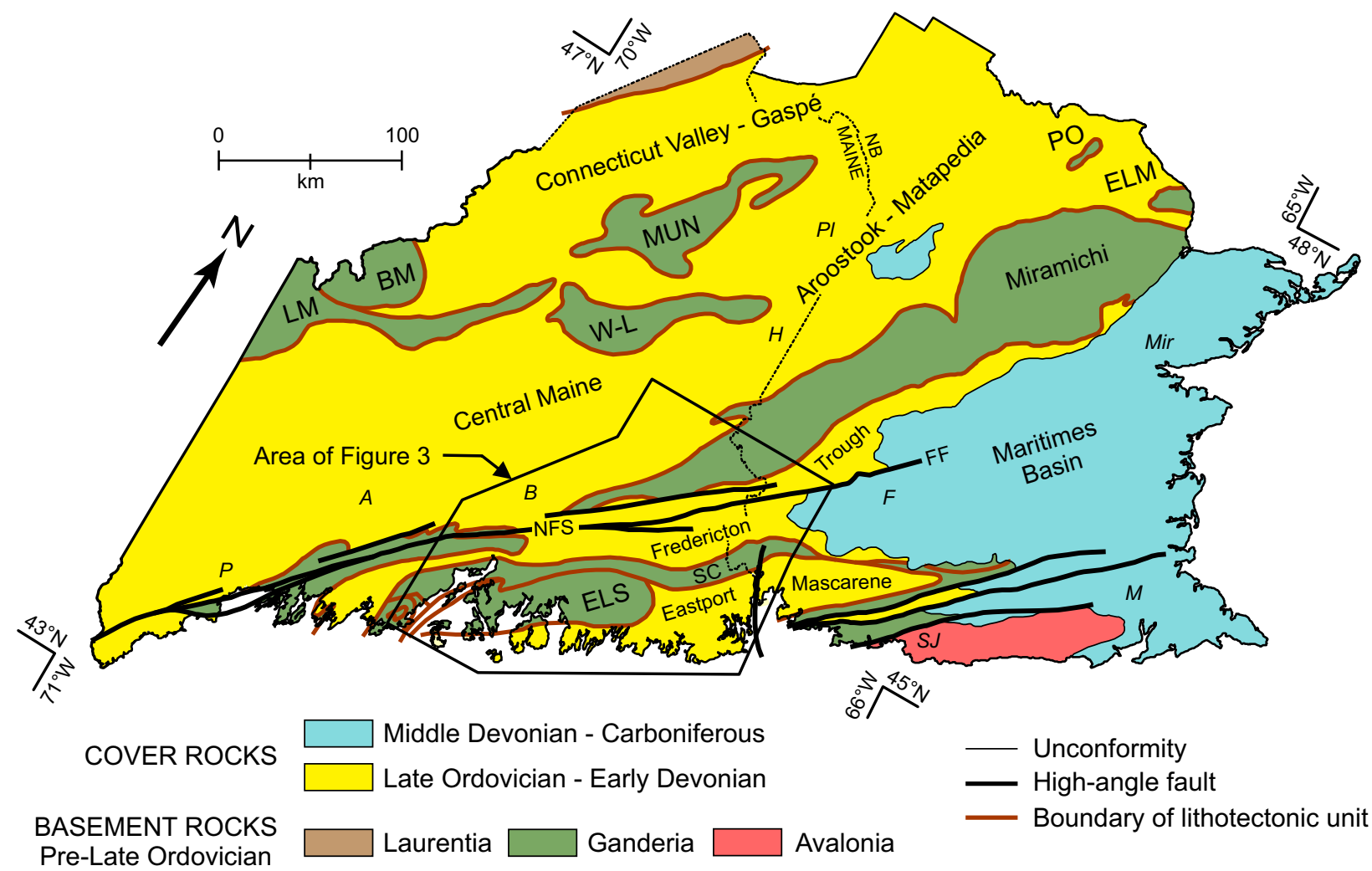

Figure 1. General distribution of Late Ordovician-Early Devonian cover rocks and tracts of exposed basement in Maine and New Brunswick (NB). Contacts have been projected through (removed) plutons to clarify general basement-cover relationships. Selected basement tracts: Lobster Mountain (LM), Boundary Mountains (BM), Weeksboro - Lunksoos Lake (W-L), Popelogan (PO), Elmtree (ELM), Ellsworth (ELS), and St. Croix (SC). Towns: Augusta (A), Bangor (B), Houlton $(H)$, Portland $(P)$, and Presque Isle (PI), Maine; Fredericton $(F)$, Miramichi (Mir), Moncton $(M)$, and Saint John (SJ), New Brunswick. Faults: Norumbega Fault System (NFS) and Fredericton Fault (FF). (Modified from Hibbard et al. 2006; Fyffe et al. 2011; Ludman et al. 2017; and Mohammadi et al. 2017.)

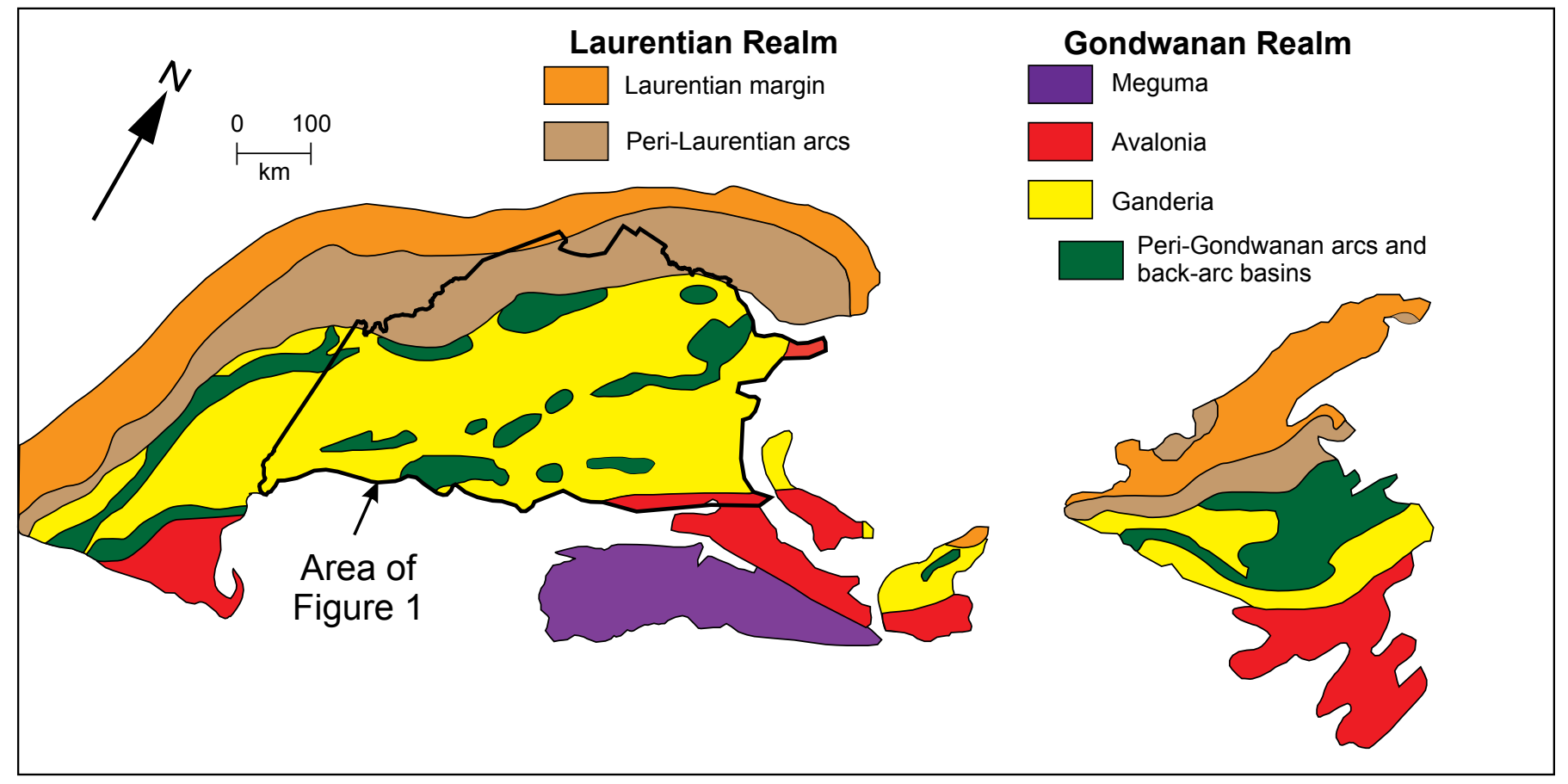

Figure 2. Tectonic framework of the northern Appalachians of New England and Canada (after Hibbard et al. 2006). 
Table 1. Tectonic evolution of the northern Appalachian study area (after Hibbard et al. 2006; Hatcher 2010; Fyffe et al. 2011; van Staal et al. 2016; Wilson et al. 2017). Shading indicates the ages of basement (brown) and cover (yellow) rocks examined in this study.

\begin{tabular}{|c|c|c|c|}
\hline & AGE & OROGENY & TECTONIC EVENTS \\
\hline \multirow{10}{*}{ 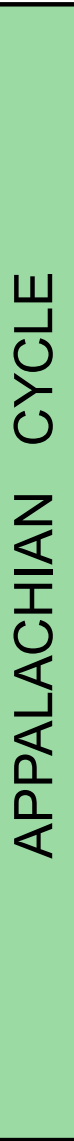 } & Permian & Alleghanian & $\begin{array}{l}\text { Gondwana accreted to previously amalgamated plates } \\
\text { forming supercontinent Pangea }\end{array}$ \\
\hline & Late Devonian & "Neoacadian" & Meguma accreted to previously amalgamated plates \\
\hline & Early Devonian & Acadian & Avalon accreted to previously amalgamated plates \\
\hline & Late Silurian & Salinic & $\begin{array}{l}\text { Accretion of Ganderia to Laurentia completed by closure of } \\
\text { remnant back-arc basin at trailing edge of Ganderia }\end{array}$ \\
\hline & Silurian & & $\begin{array}{c}\text { Continued Ganderia-Laurentia convergence by closure of } \\
\text { Tetagouche back-arc basin (Miramichi terrane) }\end{array}$ \\
\hline & Late Ordovician & & $\begin{array}{l}\text { Leading edge of Ganderia (Popelogan arc) collides } \\
\text { with Laurentia }\end{array}$ \\
\hline & Ordovician & & Continued Ganderia-Laurentia convergence \\
\hline & $\begin{array}{l}\text { Cambrian- } \\
\text { Ordovician }\end{array}$ & Penobscot & $\begin{array}{l}\text { Ganderian components (Miramichi, Annidale,) reunited } \\
\text { near trailing edge of the Ganderian plate }\end{array}$ \\
\hline & $\begin{array}{l}\text { Cambrian - Early } \\
\text { Ordovician }\end{array}$ & & $\begin{array}{l}\text { Ganderia rifted from Gondwana, drifts toward Laurentia, } \\
\text { and is fragmented by extension during lapetan subduction } \\
\text { that produces island arcs and back-arc basins }\end{array}$ \\
\hline & $\begin{array}{l}\text { Latest } \\
\text { Neoproterozoic }\end{array}$ & & Rifting of Rodinia, opening of lapetus Ocean \\
\hline & $\begin{array}{l}\text { Neoproterozoic } \\
(\sim 1 \mathrm{Ga})\end{array}$ & Grenville & Assembly of supercontinent Rodinia \\
\hline
\end{tabular}

greenschist (chlorite zone) regional metamorphic conditions with more intense metamorphism in contact aureoles surrounding numerous felsic and mafic plutons. Wellpreserved primary sedimentary features indicate that most of the cover rocks were deposited as low-, intermediate-, and high-energy turbidites.

Despite the low-grade metamorphism, both basement and cover rocks experienced complex multiphase deformation including recumbent folding and thrusting, upright folding, high-angle reverse faulting, and several episodes of late dextral strike-slip and steep normal and reverse dip-slip faulting (Ludman et al. 1993; Tucker et al. 2001; Ludman 2017). Complex faulting typically obscures critical relationships between the cover rocks and their basement terrrane sources (Osberg et al. 1989; Tucker et al. 2001; Fyffe et al. 2011; Ludman 2017; Ludman et al. 2017).

Figure 3. (next page) Generalized bedrock map of central and eastern Maine showing localities of samples analyzed in this study. Dashed rectangles show locations of detailed maps in Figure 14. Numbers indicate cover units. Sample prefixes indicating sampled units are used throughout this paper. AR: Appleton Ridge; BL: Baskahegan Lake; BM: Bowers Mountain; FR: Flume Ridge; HC: Hutchins Corner; KM: Kendall Mountain; MA: Madrid; MH: Mayflower Hill; OS: Olamon Stream; PM: Pocomoonshine gabbro-diorite; VG: Vassalboro Group, undifferentiated. Selected plutons: Bottle Lake Complex (Bot), Lucerne (Lu), Deblois (Deb). Towns: Bangor (B), Danforth (D), Ellsworth (El), Eastport (EP), Greenfield (G), Lincoln (L), Princeton (P), Rockland (R), Skowhegan (S), Waterville (W). Geology modified from Osberg et al. (1985), Tucker et al. (2001), and Ludman et al. (2017). 


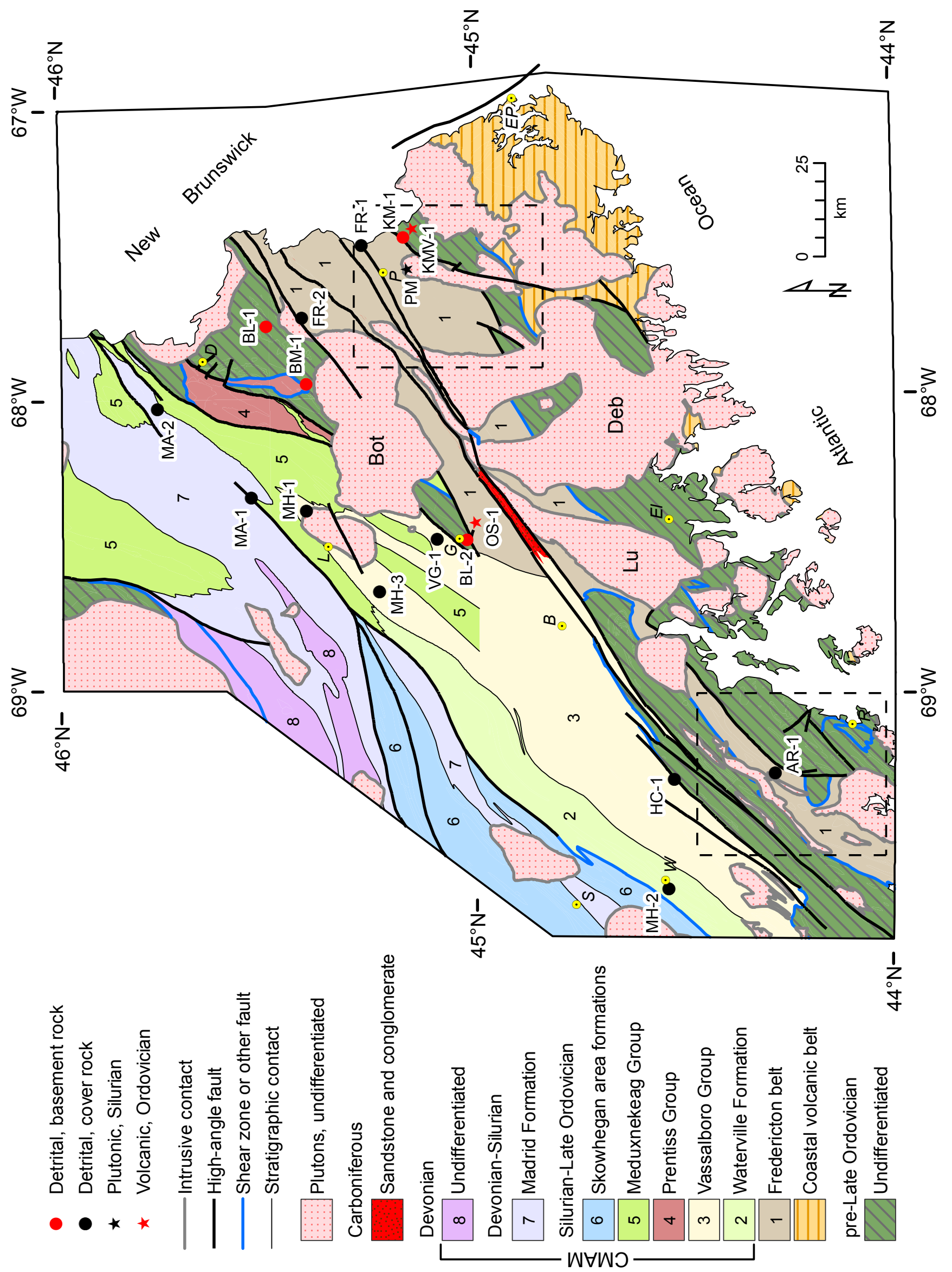




\section{Previous work}

\section{Stratigraphy}

Stratigraphic interpretations of Cambrian to Middle Ordovician basement and overlying cover successions in Maine and adjacent New Brunswick have evolved over several decades, and revisions continue today (e.g., Marvinney et al. 2010; Ludman 2013; Bradley and O'Sullivan 2016; Ludman et al. 2017). The area covered in this paper (Fig. 3) was for many years known only from reconnaissance mapping. It was surrounded by well-established stratigraphic successions in western, central, and northeastern Maine, but its relationships with the rocks of southern Maine and southwestern New Brunswick were uncertain on the two most recent Maine bedrock maps (Doyle and Hussey 1967; Osberg et al. 1985). More than 30 years of fieldwork since the 1985 Maine bedrock map was published have resolved long-standing correlation problems and provided a lithofacies framework for the detrital zircon studies reported here (summarized by Ludman et al. 2017; Ludman 2013), including:

(1) The Central Maine and Aroostook-Matapedia successions accumulated in a single depocenter - the CMAM basin - sourced from emergent highlands to the west (Boundary Mountains, Lobster Mountain, Weeksboro-Lunksoos Lake) and to the east (Miramichi), and by NE-to- SW axial currents.

(2) The Fredericton trough was a two-sided basin that received sediment from post-Middle Ordovician Miramichi and St. Croix highlands to the west and east, respectively. No similar highland is present in southwestern Maine, and relationships between Fredericton and Central Maine strata there are uncertain.

(3) Silurian lithofacies patterns adjacent to the CambrianOrdovician Weeksboro-Lunksoos Lake and Munsungun belts indicate that these areas also supplied post-Late Ordovician sediment to the CMAM basin.

(4) Sedimentation in the Fredericton trough ended in the late Silurian with onset of Salinic deformation but continued in CMAM through the Early Devonian.

(5) Acadian, Alleghanian, and post-Alleghanian folding and faulting have distorted original basin geometries and drastically telescoped the basin sediments.

Recent geologic mapping has refined the stratigraphy in the Fredericton trough in New Brunswick from that described by Ruitenberg and Ludman (1978), and provided fossil age control for some of the units (see Table 2; summarized in Dokken et al. 2018; Fyffe 1991, 1995; Fyffe and Riva 2001; Fyffe et al. 2011). Distinctive units along the northwest flank of the Fredericton trough in New Brunswick apparently are not present in Maine, perhaps due to facies changes, removal by faulting, or a combination of the two.

The basement tracts in the study area were clearly emergent and served as major internal Ganderian sediment sources for the cover rock basins following accretion of Ganderia to Laurentia (Ludman et al. 2017). It was hoped that detrital zircon age spectra might identify input from sources external to Ganderia - Laurentia and/or the approaching Avalonian plate. Our current interpretation of regional correlation is summarized in Table 2. Because of the complexity of this table, only Period and Series chronostratigraphic divisions are shown.

\section{Detrital zircon studies}

Previous detrital zircon studies in Maine and New Brunswick have helped to constrain depositional ages and determine provenance of rocks related to this study. Bradley and O'Sullivan (2016) reported detrital zircon age spectra from several proximal units on the west flank of the CMAM basin in western Maine. Discrepancies between ages of the youngest zircon grains and stratigraphic ages inferred from regional correlations suggest that some units may be as much as 15 m.y. younger than previously thought. McWilliams et al. (2010) demonstrated that the Connecticut Valley-Gaspé trough, containing the northwesternmost cover succession (Fig. 1), was derived from highlands flanking the basin. Studies in southwestern Maine, adjacent New Hampshire, and Massachusetts identified both Laurentian and Ganderian sources for rocks correlated with CMAM and Fredericton successions in an area where there is no basement block separating the two basins (Sorota 2013). Hussey et al. (2016) cited paleocurrent indicators as evidence for an eastern (peri-Gondwanan) source for rocks in southwestern Maine and southeastern New Hampshire correlated with the Fredericton trough succession.

Some detrital zircon work has been done in southwestern New Brunswick on stratigraphic units continuous with those sampled in this study. Fyffe et al. (2009) compared detrital zircon age spectra from pre-Silurian terranes in southern New Brunswick and coastal Maine to assess their tectonic settings and refine their provenance and accretionary histories. Pre-Silurian units related directly to this project include the Baskahegan Lake Formation, oldest unit in the Miramichi terrane, also reported here, and the Calais Formation in the lower part of the St. Croix terrane. Current work in New Brunswick has focused on rocks of the Fredericton trough in an attempt to clarify the tectonic setting and provenance of its thick turbidite succession (Dokken et al. 2018).

Detrital zircon studies designed to distinguish terranes and reconstruct relationships among peri-Gondwanan fragments resulting from the breakup of Rodinia are described in the Discussion section, below.

\section{Sampling strategy}

Figure 3 shows the locations of the one plutonic, two volcanic, and 14 detrital zircon samples analyzed in this study. Sampling was designed to supplement previous detrital zircon age data described above for the CMAM and Fredericton cover rocks, as well as the Miramichi and St. Croix source areas. Where prior data were available for a formation, sites were chosen to broaden geographic and stratigraphic 


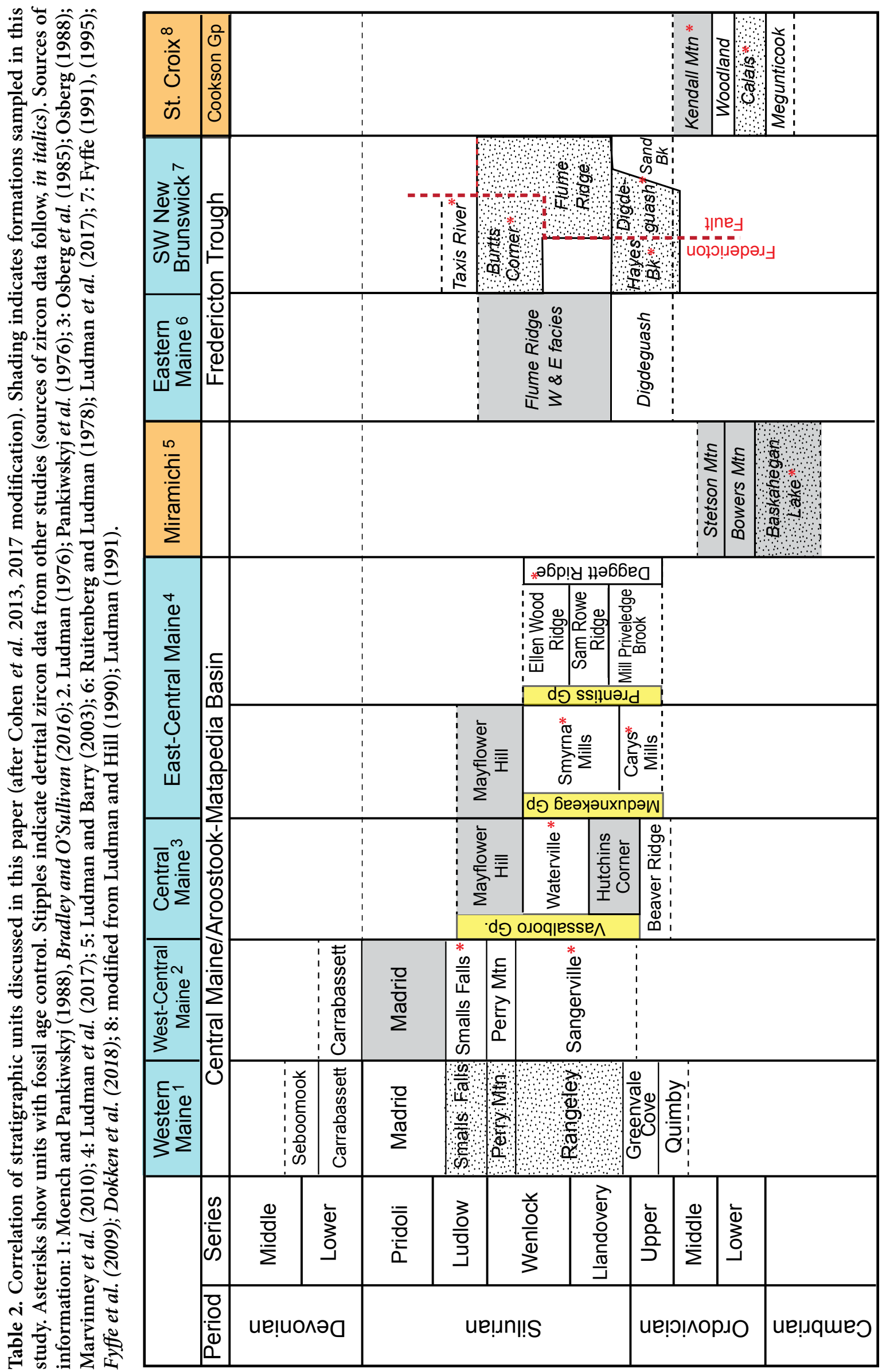


coverage in an attempt to detect possible changes in sediment source for that unit. Wherever possible, formations were sampled in areas where their stratigraphic positions are well established, at or close to where they were defined, and in the rare places where there is fossil age control. Formation abbreviations for dated samples are explained in Figure 3 and are used throughout the text, tables and appendices $\mathrm{B}, \mathrm{C}$, and $\mathrm{D}$.

\section{Plutonic zircon}

The Pocomoonshine gabbro-diorite intruded folded strata of the Fredericton trough, and thus provides a minimum age for both deposition in that depocenter and onset of Salinic deformation in eastern Maine and New Brunswick (West et al. 1992). A ${ }^{40} \mathrm{Ar} /{ }^{39} \mathrm{Ar}$ hornblende cooling age of $422.7 \pm 3 \mathrm{Ma}$ (West et al. 1992) has been the regional standard for defining the onset of Salinic deformation in Maine and New Brunswick, and a sample from near the northern margin of the Pocomoonshine gabbro-diorite was collected to compare the $\mathrm{U}-\mathrm{Pb}$ zircon crystallization age of the pluton with the previously determined hornblende cooling age.

\section{Volcanic zircon}

Samples were collected from the thick volcanic Olamon Stream Formation at the top of the Miramichi succession (OS-1) and from a tuff horizon (KMV-1) at the base of the Kendall Mountain Formation, youngest unit in the St. Croix terrane, to determine their eruptive ages, clarify stratigraphic ranges of underlying units, and constrain the timing of the Ordovician tectonism. A cryptocrystalline tuff from the Smyrna Mills Formation was also collected but proved to have insufficient zirconium to attempt zircon separation and dating.

\section{Detrital zircon}

Ten samples of cover rock were collected for detrital zircon dating; the stratigraphic problems addressed by these samples are detailed below. Eight of these samples are interpreted to have been deposited in the initial Late Ordovician Middle Silurian sedimentary regime in the CMAM basin [(Mayflower Hill (MH) and Hutchins Corner (HC) formations; Vassalboro Group (VG)], and Fredericton trough [(Flume Ridge (FR) and Appleton Ridge (AR)], and two in the subsequent Late Silurian to Early Devonian regime in CMAM [(Madrid Formation (MA)].

Four additional sedimentary rock samples were collected from basement terranes; three from the Miramichi Baskahegan Lake (BL-1, BL-2) and Bowers Mountain (BM) formations and one from the Kendall Mountain (KM-1) Formation. Nine of the fourteen detrital zircon sample sites are from chlorite-grade rocks, two from higher grades of regional metamorphism (HC-1 at biotite grade, AR-1 at andalusite + staurolite grade), and three from contact aureoles with biotite-cordierite assemblages (MH-1, BM-1, and KM-1).

\section{$\mathrm{U}-\mathrm{Pb}$ geochronology}

Zircon was extracted from 5-10 kg samples collected at outcrops shown in Figure 3. Standard mineral separation procedures included crushing and pulverizing, followed by processing over a Wilfley table, through a magnetic separator, and in heavy liquids to obtain a heavy mineral concentrate composed mostly of zircon. Detrital zircon was sprinkled onto double-sided tape to minimize sampling bias, whereas igneous zircon from three samples was hand-picked under a binocular microscope. Zircon grains were mounted in epoxy, ground to about half thickness, and sequentially polished using $6 \mu \mathrm{m}$ and $1 \mu \mathrm{m}$ diamond suspension. All polished grains were imaged in reflected and transmitted light on a petrographic microscope, and in cathodoluminescence (CL) using the USGS-Denver JEOL5800LV scanning electron microscope (SEM).

Zircon was dated by the U-Pb method using the USGS/ Stanford sensitive high-resolution ion microprobe-reverse geometry (SHRIMP-RG) at Stanford University following the methods described in Williams (1998). For all analyses, the primary beam was about $20-25 \mu \mathrm{m}$ in diameter. For igneous zircon, the magnet was cycled through the appropriate mass stations five or six times, whereas for detrital zircon the magnet was cycled four times to maximize the number of grains analyzed (between 60 and 70 grains per sample). Measured ${ }^{206} \mathrm{~Pb} /{ }^{238} \mathrm{U}$ ratios for zircon analyses were normalized to the value for standard R33 (ca. 419 Ma; Black et al. 2004).

SHRIMP data for zircon were reduced using Squid 2 (Ludwig 2009) and plotted using Isoplot 3 (Ludwig 2003). Nested concordia plots for detrital zircon ages from 14 cover rock and basement sandstones are shown in Figure 4. $\mathrm{U}-\mathrm{Pb}$ data for detrital zircon are screened such that ages that are greater than $10 \%$ discordant (Fig. 5) are excluded from the relative probability plots that display age distributions. For the entire detrital zircon data set of 916 analyses, nine analyses were excluded. These include: \#26, 40 for BL2; \#17 for MH-1; \#22, 37, 51, 63 for VG-1; and \# 26, 47 for MA-1. For relative probability plots, we used ${ }^{206} \mathrm{~Pb} /{ }^{238} \mathrm{U}$ data for ages $<1300 \mathrm{Ma}$, and ${ }^{207} \mathrm{~Pb} /{ }^{206} \mathrm{~Pb}$ data for ages $>1300 \mathrm{Ma}$. Ages of igneous rocks are calculated as concordia ages (Ludwig 1980, 2003) and reported with 2-sigma uncertainties. Concentrations of $U$ and $T h$ are believed to be accurate to about $\pm 20 \%$, and are used only for comparing analyses.

\section{RESULTS}

Nested concordia plots for detrital zircon ages from the 14 cover and basement sandstones are shown in Figure 4, and Figure 5 contains complete detrital zircon age spectra for the sampled rocks. Two general conclusions can be drawn from Figure 5: (1) The presence of Silurian zircon grains solely in the cover rocks and the much older ages of the youngest basement rock zircon grains confirm that the two suites have significantly different ages, and (2) zircon 


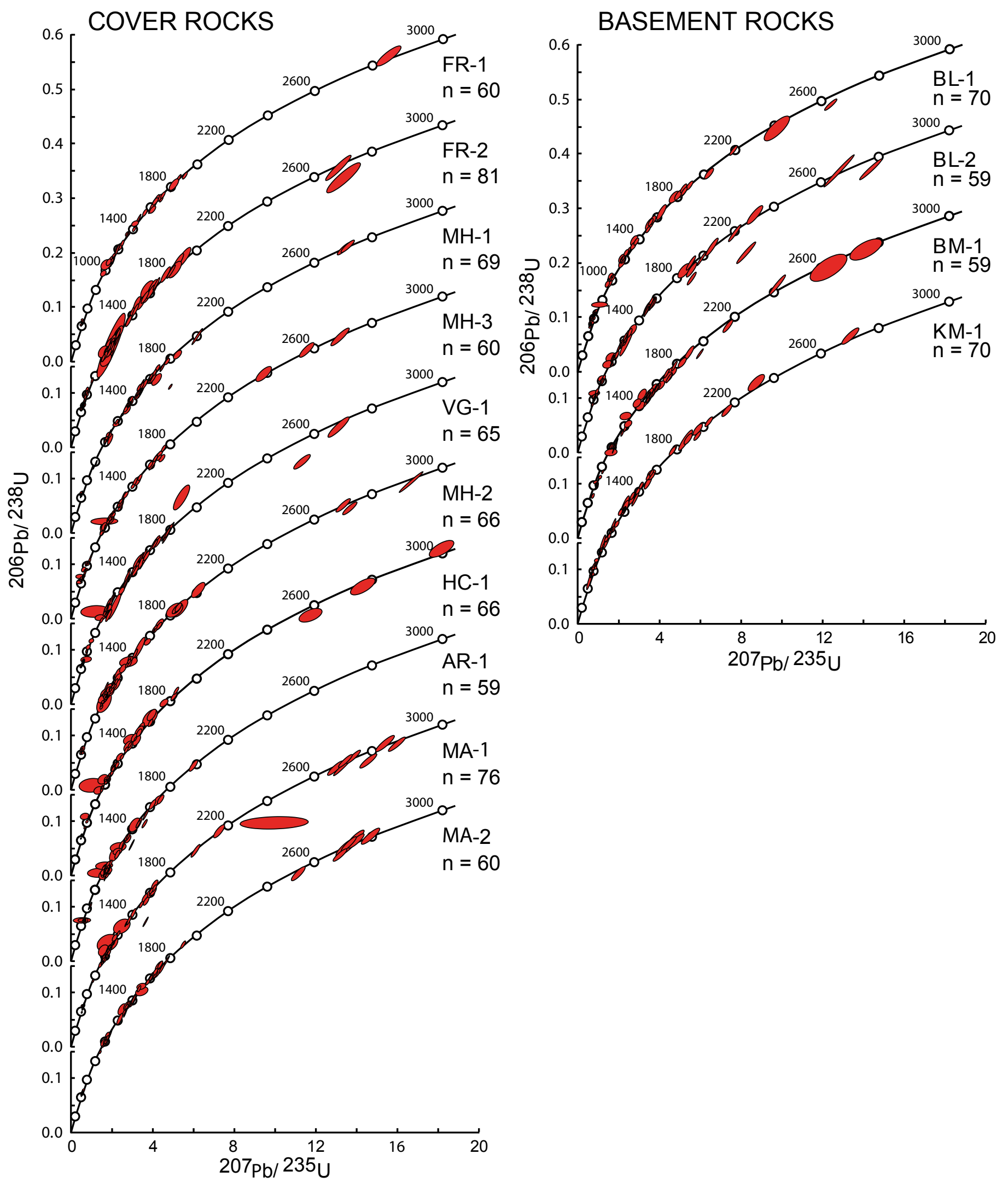

Figure 4. Nested concordia plots for detrital zircon from cover and basement rocks. Formation labels as in Figure 3. 
(a) COVER ROCKS
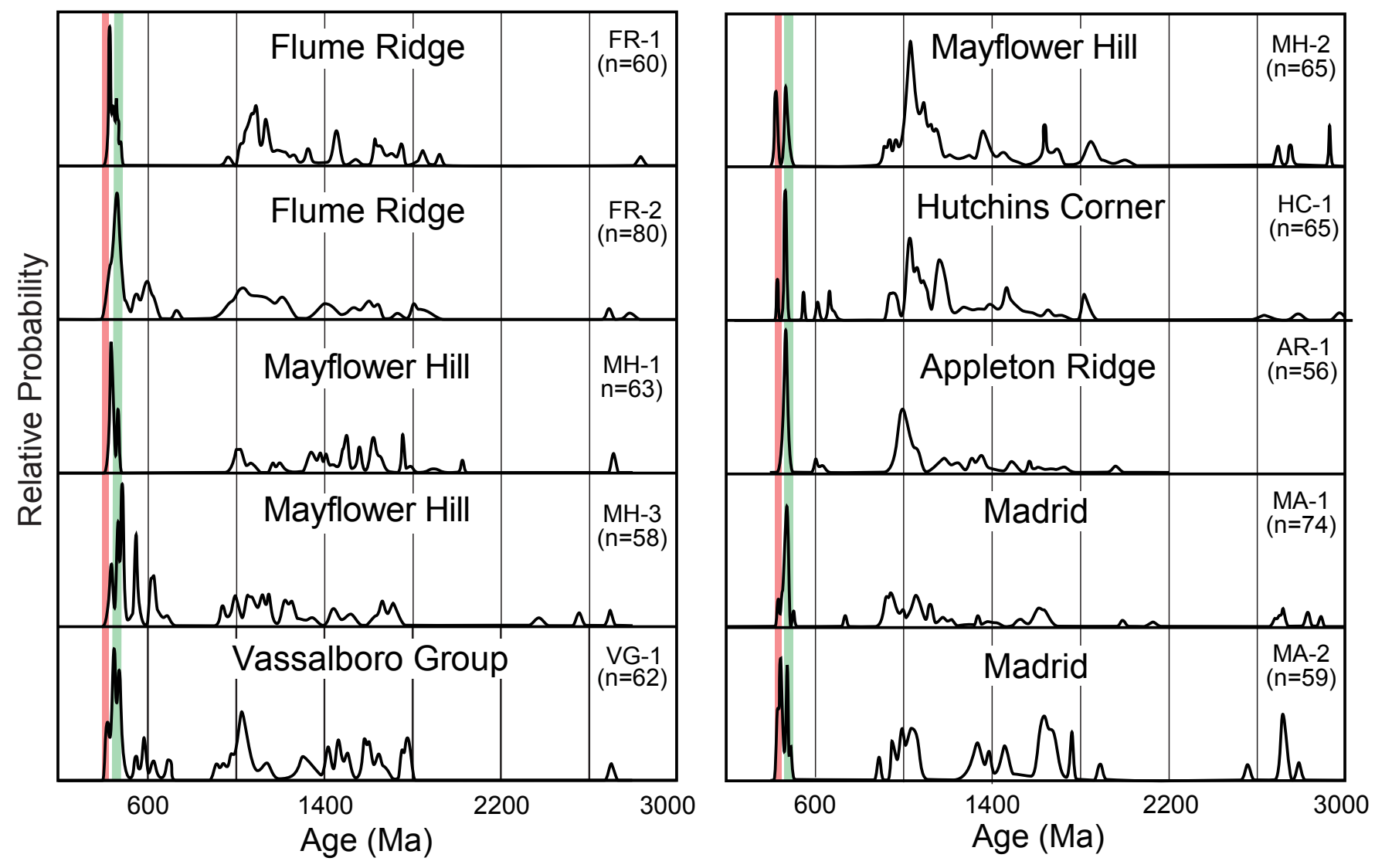

(b) BASEMENT ROCKS

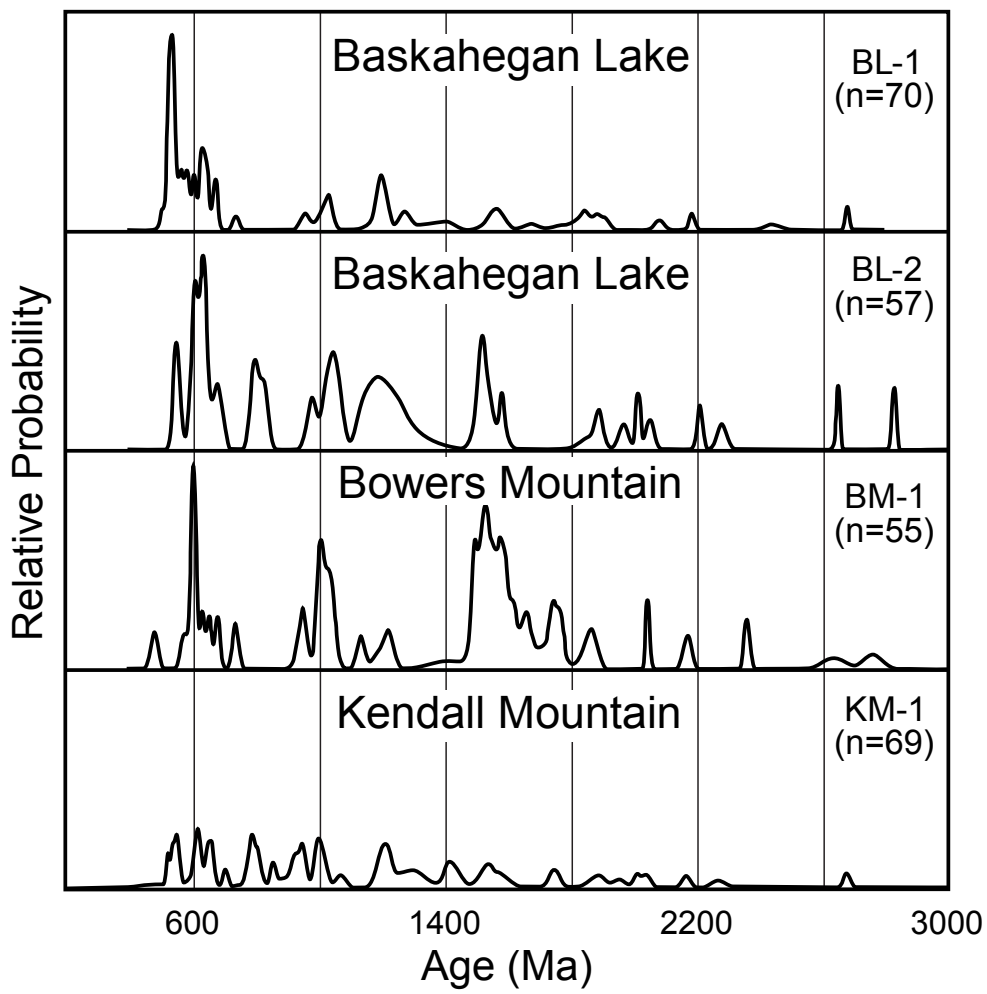

Figure 5. Complete detrital zircon age spectra for formations sampled in this study. In (a), green shading indicates span of Ganderian volcanism (after Wilson et al. 2015) and pink shading indicates Eastport-Mascarene volcanism. Sample identification as in Figure 3. 
populations between 2.0 and $2.5 \mathrm{Ga}$ in the basement rocks are absent from the cover rocks, suggesting a source not tapped by the younger strata.

Additional results addressing specific stratigraphic problems of the basement and cover successions are described below, combining detrital zircon, paleontological, and field evidence. The crystallization age of the Pocomoonshine gabbro-diorite is presented first as it constrains both stratigraphic ages of the Fredericton cover succession and the timing of Late Silurian (Salinic) tectonism. Boundaries between stratigraphic stages cited throughout this paper are from the International Chronostratigraphic Chart (Cohen et al. 2013; 2017 modification).

The age of the youngest detrital zircon grains in a rock is, ideally, a maximum deposition age for the host formation. Conditions in this study are far from ideal, partly because of uncertainties about the stratigraphic positions of some samples within their formations, ages based on poorly preserved fossils, and limits to which a single detrital zircon- or fossil-based age can be applied to a formation thousands of metres thick. Appendix A compares current chronostratigraphic nomenclature with that used in reporting Maine fossil ages in the 1950s through 1980s. The significance of each dated sample is given in Appendix B, and all analytical data are reported in Appendices $C$ and $D$.

Analytical issues are also problematic, as analytical error for most samples (Appendices C and D) typically spans one or more Silurian and/or Ordovician stages. Finally, the youngest zircon age in some samples comes from only one or two zircon grains and, although interesting, these are statistically unreliable. Despite these obstacles, the data do provide new insights into the ages and ranges of the sampled formations. In addition, volcanic zircon from the Miramichi and St. Croix basement terranes provide eruptive ages that help resolve stratigraphic problems described below.

\section{Age of the Pocomoonshine gabbro-diorite}

Zircon from the northern part of the Pocomoonshine gabbro-diorite (Fig. 6a) was extracted from a sample of finegrained gabbro (Fig. 6b). These grains are subhedral to anhedral, and display fine oscillatory zoning (Fig. 6c) indicative of an igneous origin. $\mathrm{U}-\mathrm{Pb}$ isotopic data of 18 analyses are concordant and result in a concordia age of $421.9 \pm 2.4 \mathrm{Ma}$ (Fig. 6d). This age overlaps within uncertainty with the $422.7 \pm 3 \mathrm{Ma}{ }^{40} \mathrm{Ar} /{ }^{39} \mathrm{Ar}$ hornblende cooling age (West et al. 1992), confirming that the Pocomoonshine gabbro-diorite was emplaced during the Late Silurian. The overlap also indicates that the pluton cooled rapidly and was emplaced at a shallow crustal level.

\section{Ages and relationships of basement units}

\section{Miramichi terrane}

The Miramichi terrane extends southwestward for more than $300 \mathrm{~km}$ from northern New Brunswick into Maine where it narrows and terminates abruptly at the surface in the Greenfield area (Fig. 1; Ludman 2018). The Bottle Lake pluton divides the terrane in Maine into northern (Danforth) and southern (Greenfield) segments (Fig. 3). The two segments have similar stratigraphies, with the turbiditic Baskahegan Lake Formation at the base of each, overlain by a dominantly pelitic, partially euxinic, unit and capped by a thick volcanic section. The upper parts of these sections are sufficiently dissimilar to require different nomenclature (Fig. 7).

The Baskahegan Lake Formation comprises turbiditic quartzofeldspathic and quartzose sandstone with varying amounts of interbedded slate. The base of the overlying Bowers Mountain Formation in the Danforth segment is mostly black sulfidic shale with quartz arenite that pass upward into interbedded gray shale and siltstone. The equivalent Greenfield Formation in the Greenfield segment contains some black shale but also has numerous manganese-rich mudstone/siltstone horizons and a distinctive manganiferous iron formation. A thick succession of dacitic, rhyodacitic, and andesitic tuffs and flows form the tops of both segments. The Stetson Mountain volcanic rocks (Danforth segment) are typically fine grained ashfall tuffs with subordinate crystal tuffs and sparse coarser-grained ashflow tuffs, whereas the equivalent Olamon Stream volcanics (Greenfield segment) are coarser (including a few agglomerates), and have more flows and crystal or lithic tuffs.

Correlation with fossil-bearing units outside the study area suggests a Cambrian to Middle Ordovician age range for the Miramichi succession in Maine. The lower limit is based on correlation of the Baskahegan Lake Formation with the Grand Pitch Formation in the Weeksboro-Lunksoos Lake terrane (Fig. 1), which contains the Early to Middle Cambrian trace fossil Oldhamia (Neuman 1984). Ichnofossils in New Brunswick (Pickerill and Fyffe 1999) indicate that the Baskahegan Lake Formation extends into the Early Ordovician but is older than the overlying late Tremadocian Bright Eye Brook Formation (Fyffe et al. 1983). The upper age limit of the Miramichi succession in Maine is set by poorly constrained "Lower to Middle Ordovician" graptolites in the Stetson Mountain Formation (Larrabee et al. 1965). Until this study there had been no direct evidence for the age of the Bowers Mountain Formation, nor radiometric age control for the volcanic section in Maine.

Igneous zircon was collected from a felsic lava in the Olamon Stream Formation (OS-1) to directly date this formation and, indirectly, the correlative Stetson Mountain Formation. Detrital zircon from sandstone near the base of the Bowers Mountain Formation (BM-1) and from Baskahegan Lake sandstones in both segments (BL-1, BL-2) was dated in an attempt to constrain the ages and ranges of these formations.

Olamon Stream Formation: The first radiometric age of Miramichi volcanism in Maine is provided by zircon from the Olamon Stream Formation (OS-1). The sample, originally thought to be in place, proved to be part of a train of extremely coarse glacial debris derived from outcrops of 

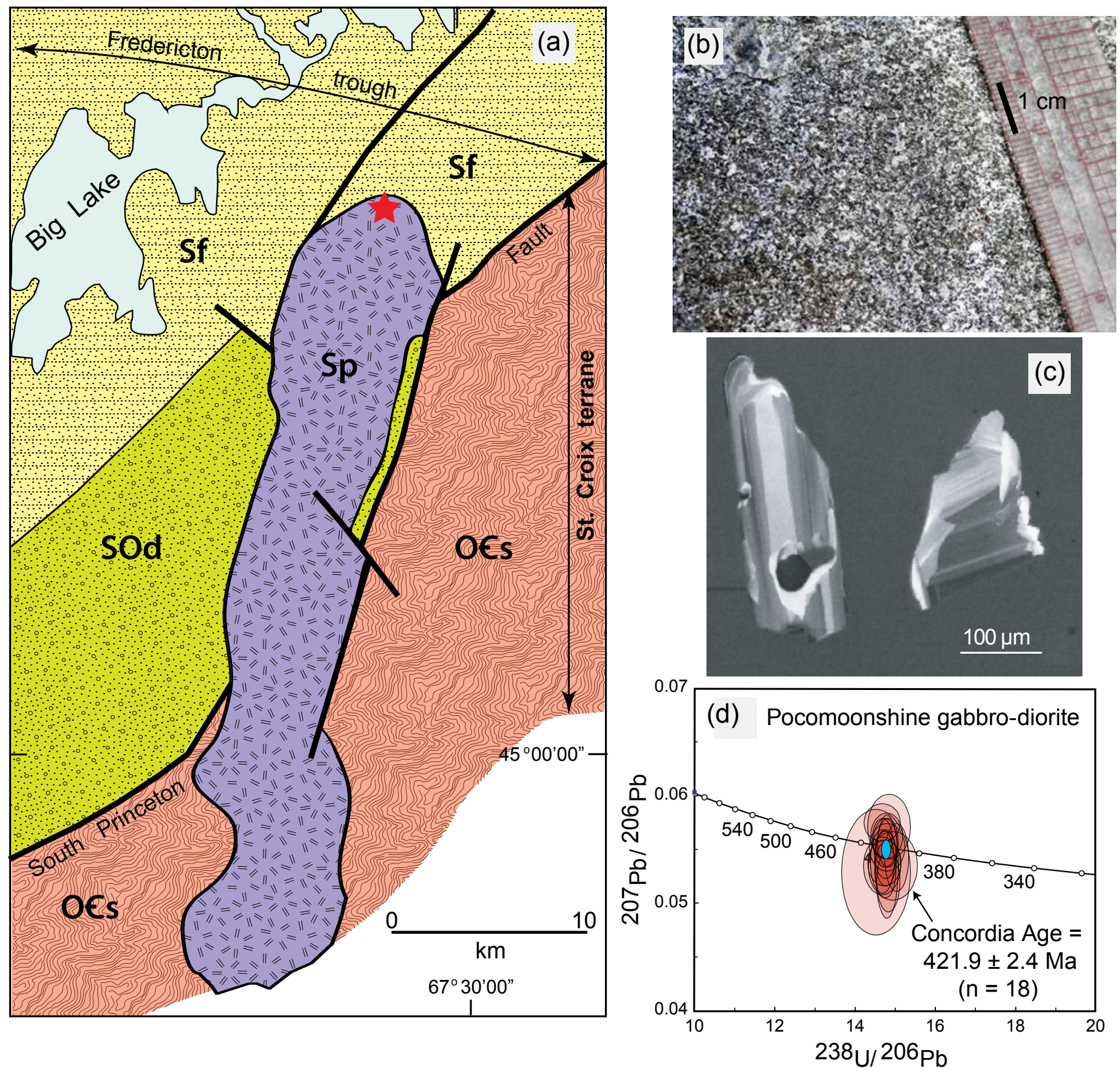

Figure 6. Age of the Pocomoonshine gabbro-diorite. (a) Intrusive relationships showing Pocomoonshine gabbro-diorite sealing the Fredericton trough/St. Croix boundary (after Osberg et al. 1985). Star shows location of dated sample. Sp= Pocomoonshine gabbro-diorite; Fredericton trough: $\mathrm{Sf}=$ Flume Ridge; $S O d=$ Digdeguash; St. Croix terrane: $\mathrm{O} \in \mathbf{s}=\mathrm{Cook}-$ son Group. Thin lines = stratigraphic and intrusive contacts. Thick lines = faults. (b) Fine grained gabbro sample dated. (c) Cathodoluminescence image of typical zircons. (d) Concordia diagram showing distribution of measured ages.

identical rock about a kilometre to the north of the sampling site. The rock is a crystal-rich felsic lava flow containing abundant $2-8 \mathrm{~mm}$ quartz and feldspar phenocrysts in a buff-weathering, very fine-grained matrix (Fig. 8a). Zircon from the Olamon Stream felsic lava is fairly coarse $(\sim 100$ $200 \mu \mathrm{m}$ ), euhedral, and displays fine, concentric oscillatory zoning (Fig. $8 \mathrm{~b}$ ), suggesting an igneous origin. A few grains contain partially resorbed cores; two analyses of cores yielded ages of about 660 and $550 \mathrm{Ma}$, thought to represent inheritance of Neoproterozoic xenocrystic zircon from an unknown source.

$\mathrm{U}-\mathrm{Pb}$ isotopic data of 15 analyses yield a concordia age of $469.3 \pm 4.6 \mathrm{Ma}$ (Fig. 8c), at the boundary between the Lower and Middle Ordovician (Floian-Dapingian), and is interpreted as the eruption age of the felsic lava. This age for the youngest formation in the Miramichi succession 

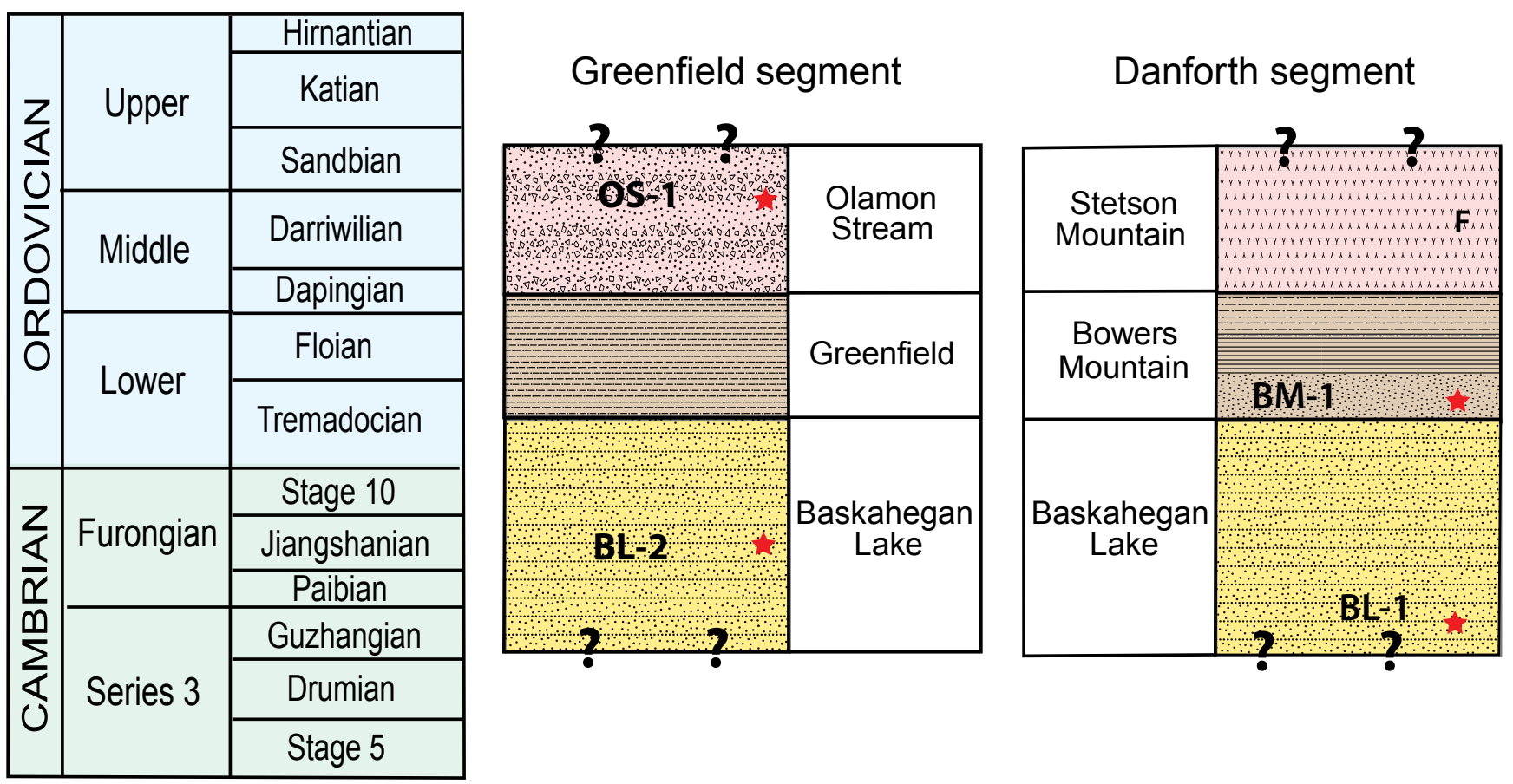

Figure 7. Stratigraphy of the Greenfield and Danforth segments of the Miramichi terrane in Maine. Stars = zircon samples. $\mathrm{F}=$ fossils. Positions of samples and fossils within formations uncertain except for BM-1.

also constrains the range of the underlying units and is the maximum age for subsequent Ordovician deformation (see Discussion below).

Bowers Mountain and Baskahegan Lake formations: Figure 9 is an expanded excerpt from Figure 5a, highlighting the Late Neoproterozoic to Early Cambrian ages of the youngest detrital zircon grains in the four basement units sampled. The absence of Silurian zircon clearly distinguishes all four units from the younger cover rocks. The latest Neoproterozoic to earliest Cambrian age of the youngest zircons in the Baskahegan Lake Formation is consistent with its Cambrian-Early Ordovician age described above, and with zircon ages from the formation in New Brunswick (Fyffe et al. 2009). Unfortunately, the youngest zircon ages in the Bowers Mountain and Kendall Mountain formations are not statistically robust enough to establish a youngest age population as they were found in only one grain each (Fig. 9).

\section{St. Croix terrane}

Stratigraphic ages of units in the St. Croix terrane shown in Table 2 are based on fossils in the lower and uppermost formations of the succession. Tremadocian graptolites at Cookson Island indicate an Early Ordovician age for the upper part of the Calais Formation, above a thick basal pillow basalt member. Graptolites in black shale interbedded with quartz arenite in the Kendall Mountain Formation suggest a Late Ordovician (Caradoc) age (Fyffe and Riva 1990) but there is no age control for the intervening Woodland Formation.

The age and stratigraphic affinity of the Kendall Mountain
Formation have been debated. Fyffe et al. (2009) proposed that this formation lies conformably below the Digdeguash Formation, but Ludman (1990) mapped a terrane-bounding fault between the two formations and interpreted the Kendall Mountain as the youngest formation in the St. Croix terrane. This study attempted to resolve this issue by (1) acquiring a detrital zircon age spectrum for the Kendall Mountain (KM-1) to compare with those of the Digdeguash (Fyffe et al. 2009; Dokken et al. 2018) and basement units, and (2) dating a tuff horizon (KMV-1) just above the contact with the underlying Woodland Formation.

Kendall Mountain Formation: Zircon was extracted from a white, cryptocrystalline felsic rock (KMV-1) interpreted as an ashfall tuff interbedded with thinly laminated black shale and siltstone near the base of the Kendall Mountain Formation (Figs. 10a-b) in the St. Croix terrane. These grains are fine $(\sim 50-100 \mu \mathrm{m}$ in length), euhedral, and display fine, concentric oscillatory zoning, indicative of an igneous origin (Fig. 10c).

$\mathrm{U}-\mathrm{Pb}$ isotopic data for 16 grains yield a concordia age of $477.4 \pm 3.7 \mathrm{Ma}$ (Fig. 10d). This age is interpreted as the time of eruption of the felsic tuff and thus dates the base of the Kendall Mountain Formation as Lower Ordovician (Floian-Tremadocian). It is considerably older than the Late Ordovician (Caradoc) fossil-based age for the formation but is compatible with detrital zircon ages from overlying quartz arenites (see below).

Contributions of zircon ages to basement stratigraphy: Figure 11 shows the relationships between detrital and volcanic zircon ages obtained in this study with the stratigraphic ages of their host rocks. In the Miramichi terrane, ages of the 


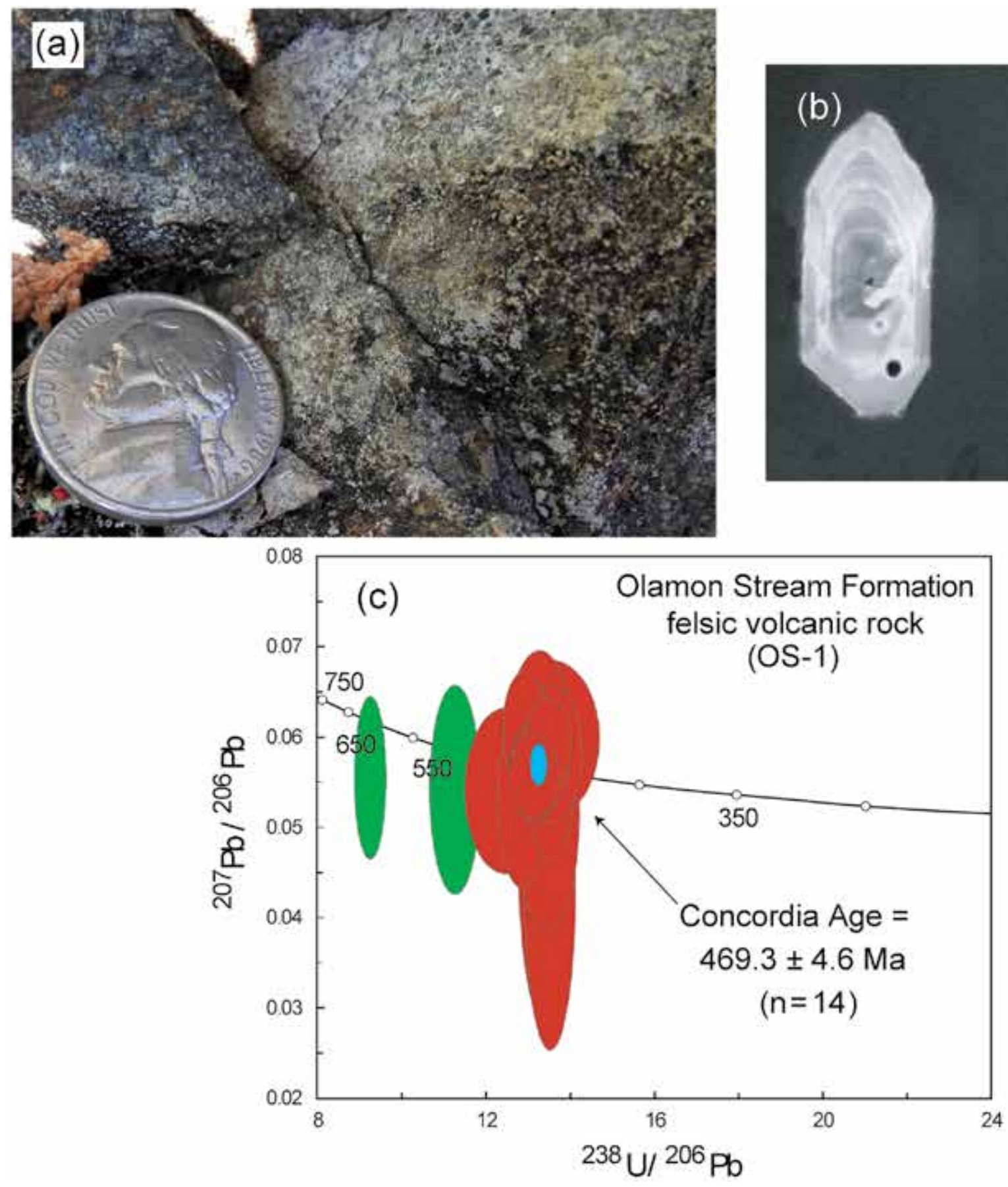

Figure 8. Age of the Olamon Stream lava. (a) Close-up showing microporphyritic lava. (b) Typical zircons dated. Note inherited core on grain to right. (c) Concordia diagram showing distribution of measured ages. Red ellipses are igneous analyses, green are inherited zircons.

youngest zircons in the Baskahegan Lake Formation are statistically significant and consistent with its proposed Cambrian to Early Ordovician age. They set maximum Late Neoproterozoic and Early Cambrian depositional ages for the Miramichi succession in the Greenfield and Danforth segments, respectively but constrain the age of the formation only slightly. The age of the youngest Bowers Mountain detrital zircons could potentially have limited the upper range of the Baskahegan Lake Formation but the single $485 \mathrm{Ma}$ age is statistically insignificant. The $469.3 \pm 4.6 \mathrm{Ma}$ age for the Olamon Stream lava dates one horizon within the thick Miramichi volcanic pile. It also limits the age of the Bowers Mountain Formation to the Early Ordovician, between that eruptive age and the Cambrian-Early Ordovician ichnofossils in the underlying Baskahegan Lake Formation (Pickerill and Fyffe 1999).

In the St. Croix terrane, ages of volcanic and detrital zircons in the Kendall Mountain Formation improve 


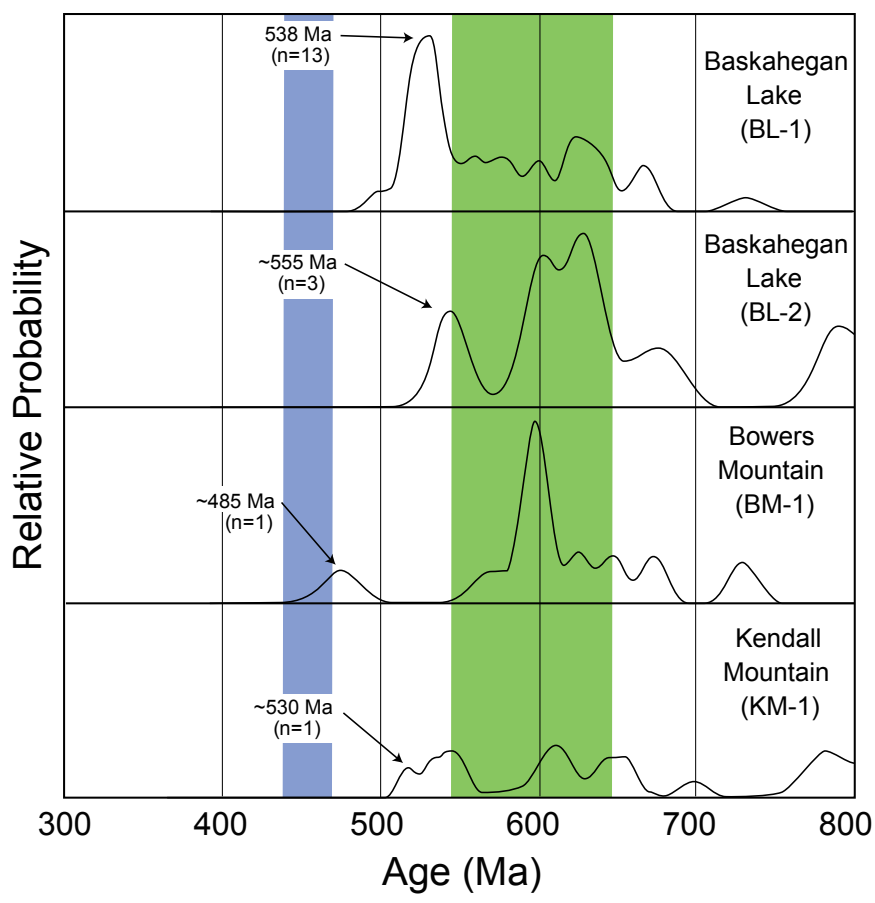

Figure 9. Excerpt of relative probability plot for basement samples showing details of youngest zircon populations. Blue $=$ Span of Ganderian volcanism; Green $=$ Avalonian .

understanding of Cookson Group stratigraphy in three ways. First, the $477.4 \pm 3.7 \mathrm{Ma}$ age of the volcanic horizon just above the base of the formation narrows the range of the underlying Woodland Formation to a narrow span in the Tremadocian, bracketed between the Kendall Mountain volcanic horizon and the Tremadocian fossils in the Calais Formation (Cumming 1967; Fyffe and Riva 1990). Second, if the fossil-based Caradocian age of the Kendall Mountain is correct, the range of the formation would span much of the Ordovician Period, from Tremadocian through Caradocian (Fig. 11, right column). Finally, the detrital zircon age spectrum for Kendall Mountain quartz arenite (KM-1) differs significantly from that of the adjacent Digdeguash Formation (Dokken et al. 2018) from which it is separated by a terrane-bounding fault (Ludman 1990; Mohammadi et al. 2017), but is similar to those of the Miramichi basement units, confirming the basement rock status of the Kendall Mountain.

\section{Ages and relationships of cover rocks}

The youngest zircon populations in all but one of the sandstones from the Fredericton trough and CMAM localities shown in Figure 3 are between ca. 434 and $422 \mathrm{Ma}-$ Middle (Wenlock) to Upper (Ludlow) Silurian (Fig. 12). The exception is the Appleton Ridge Formation whose youngest zircon population is ca. $469 \pm 3 \mathrm{Ma}$. Although the ages of the youngest zircon grains are suggestive, they are represented for most samples by only one or two grains, too few to be useful in providing reliable maximum ages of individual units (Dickinson and Gehrels 2009).

The suggested presence of ca.422 to $434 \mathrm{Ma}$ detrital zircon
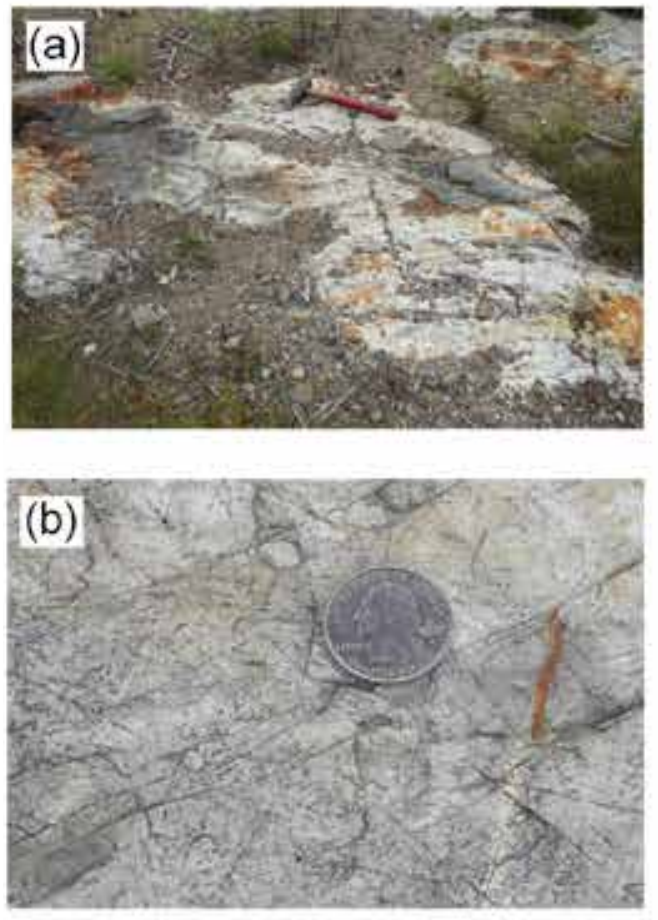

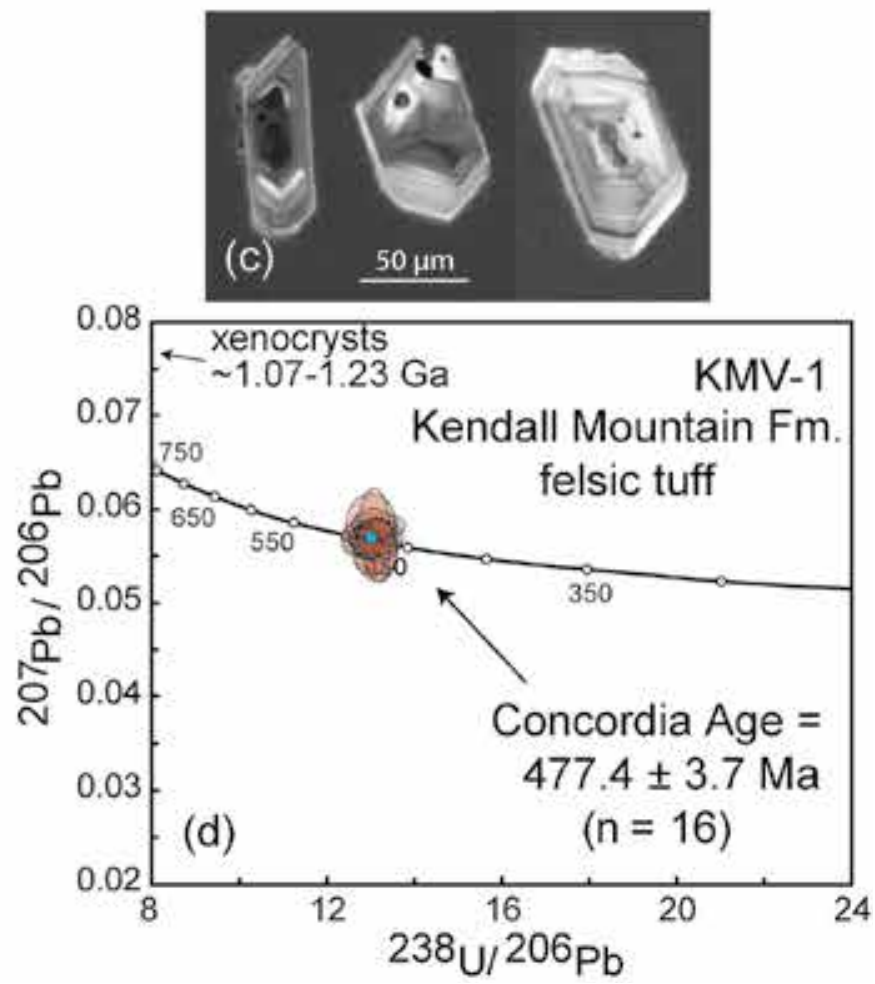

Figure 10. Age of Kendall Mountain volcanic horizon. (a) KMV outcrop showing subhorizontal black shale and whiteweathering tuff. (b) Close-up of the dated tuff. (c) Typical zircon from tuff horizon. (d) Concordia diagram showing individual zircon analyses with 2 -sigma uncertainties and calculated concordia age. 


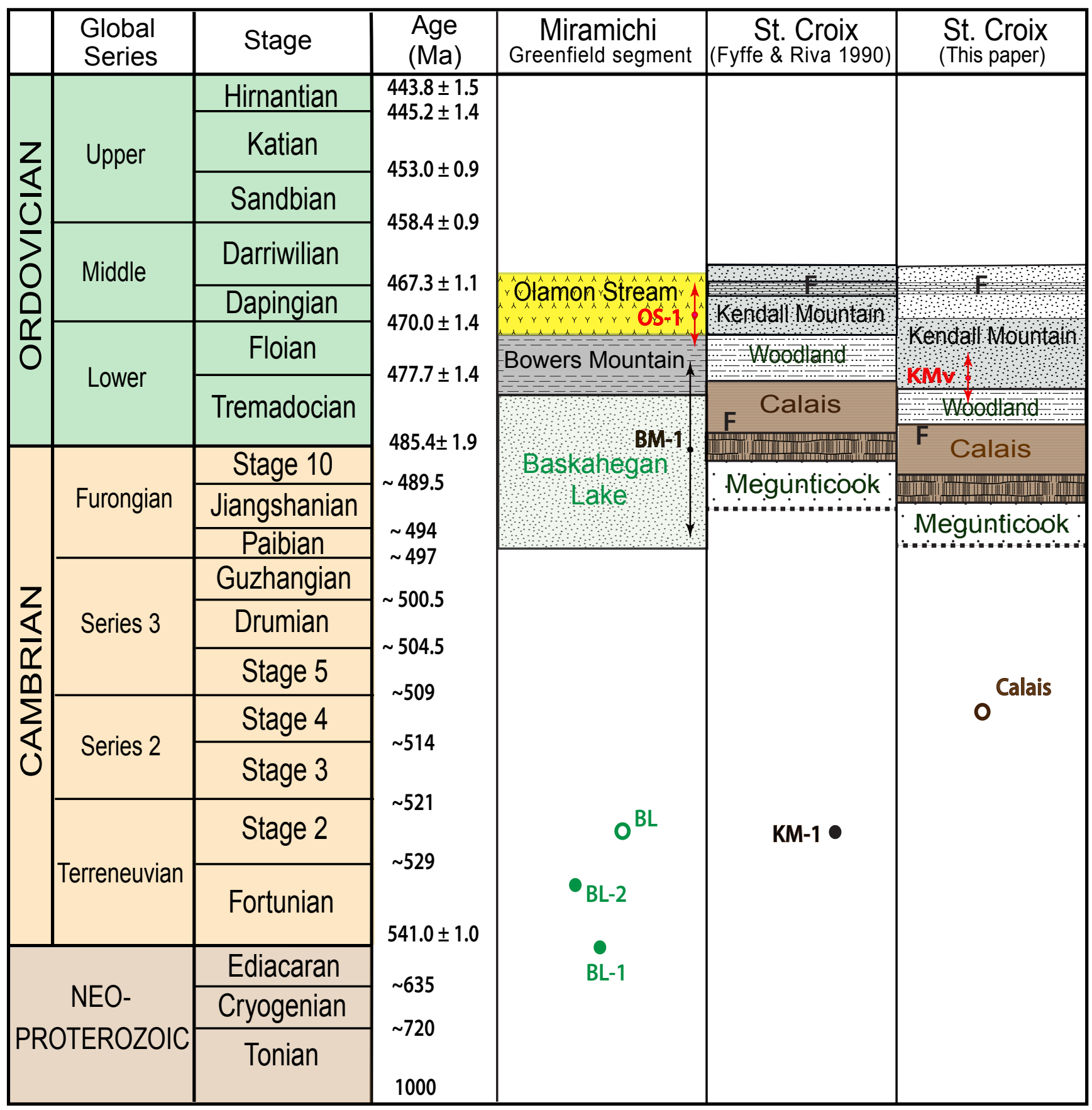

Figure 11. Isotopic and paleontological evidence for ages of Miramichi and St. Croix basement successions. Filled circles = ages of youngest zircon from this study; Open circles = data from Fyffe et al. (2009); Red stars = eruptive ages with error bars.

grains in formations known or inferred to be Silurian mirrors data reported from western Maine (Bradley and O'Sullivan 2016), and southwestern Maine, southeastern New Hampshire, and Massachusetts (Wintsch et al. 2007; Sorota 2013). These Middle to Late Silurian ages overlap the putative ages of several of their host rocks and have raised questions about the accuracy of the stratigraphic assignments and/or the measured ages.

In many instances, it is unlikely that there was enough time for those zircon grains to crystallize in an igneous rock and then be exhumed, weathered, eroded, deposited in units thousands of metres thick, and lithified before well-dated deformation (in the Fredericton trough) or deposition of overlying Late Silurian to Early Devonian strata (in CMAM). The most likely explanation for these zircon grains is direct derivation from tephra eruptions. The timing and broad geographic distribution of zircons of this age is compatible with Silurian "supervolcano" eruptions in coastal Maine that produced volumes of tephra comparable to those of the largest measured eruptions (Seaman and Hamdi 2018). The suggested Wenlockian timing corresponds with tephra eruptions of the Dennys Formation in the Eastport-Mascarene 


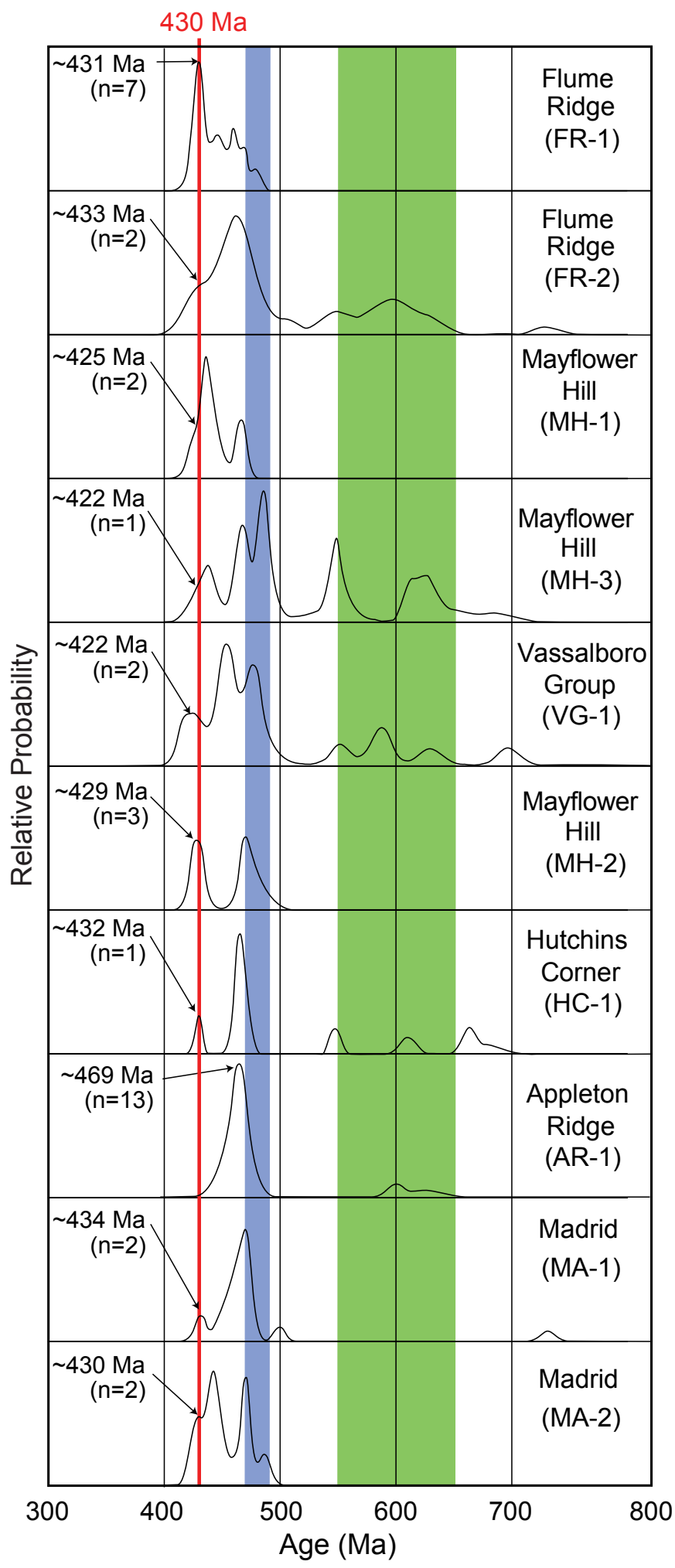

Figure 12. Excerpt from relative probability plots showing youngest detrital zircon from cover rocks. Blue $=$ Span of Ganderian volcanism; Green = Avalonian .

arc (Gates and Moench 1981; see Fig. 1), although this would imply a slightly older eruption than those dated by Seaman and Hamdi (2018).

\section{Fredericton trough}

Figure 13 shows the current interpretation of Fredericton trough stratigraphy in eastern Maine and New Brunswick. The Flume Ridge Formation underlies more than $75 \%$ of the Fredericton Trough in Maine and is divided into western and eastern facies. The western facies, close to the Miramichi terrane, is characterized by coarser grains, more abundant lithic fragments and pelite, thicker beds, and lower carbonate content than the eastern facies exposed in the central and eastern parts of the trough. Fossils have not been found in Maine but provide good age control for units in the western part of the Fredericton trough in New Brunswick (Fig. 13) and for at least part of the Digdeguash Formation on the east flank of the basin (Dokken et al. 2018).

Zircon from calcareous wackes of the Flume Ridge eastern (FR-1) and western (FR-2) facies were dated for comparison with data from New Brunswick (Dokken et al. 2018) and to broaden the geographic distribution of zircon ages from this widespread formation. The Digdeguash Formation was not sampled in this study; however, zircons from the mid-coastal Appleton Ridge Formation (AR-1) were dated to test its proposed equivalence with the Digdeguash (e.g., Hussey et al. 2010; Berry et al. 2016).

Flume Ridge Formation: The age of the Flume Ridge Formation had previously been bracketed between early $\mathrm{Si}$ lurian graptolites (Upper Rhudannian; ca. $440 \mathrm{Ma}$ ) in the underlying Digdeguash Formation (Fyffe and Riva 2001) and the $421.9 \pm 2.4 \mathrm{Ma}$ Pocomoonshine gabbro-diorite that intrudes folded Flume Ridge and Digdeguash strata. The youngest zircon grains in FR-1 and FR-2 are ca. $430 \mathrm{Ma}$, providing a maximum age for deposition of the formation and narrowing its range to $430-421.9 \pm 2.4 \mathrm{Ma}$ (Wenlock to Pridoli).

Digdeguash Formation: The Digdeguash Formation lies conformably and gradationally below the Flume Ridge in eastern Maine (Ludman 1990). Rhuddanian graptolites from an uncertain stratigraphic level indicate an early Llandoverian age for part of the Digdeguash (Fyffe and Riva 2001) but the 430 Ma youngest Flume Ridge zircons suggest that it may be as young as Wenlockian. The lower range of the Digdeguash is unknown, but is limited by its youngest detrital zircons, a small population around $490 \mathrm{Ma}$ (late Cambrian; Dokken et al. 2018).

Age of the Appleton Ridge Formation and relationship to the Digdeguash Formation: The Fredericton cover succession is truncated to the southwest by the ca. $384 \mathrm{Ma}$ Deblois pluton (Ludman et al. 1999) and ca. 380 Ma Lucerne pluton (Wones and Ayuso 1993) (Fig. 3). Large roof pendants in these plutons mapped as Bucksport Formation are very similar to the Flume Ridge Formation, and Appleton Ridge lithology and bedding southwest of these plutons are similar to those of the Digdeguash Formation (Fig. 14). The Bucksport and Appleton Ridge formations thus appear to extend the Flume Ridge-Digdeguash succession of the Fredericton trough to the west shore of Penobscot Bay (Fig. 14).

The age of the Appleton Ridge Formation is uncertain, 


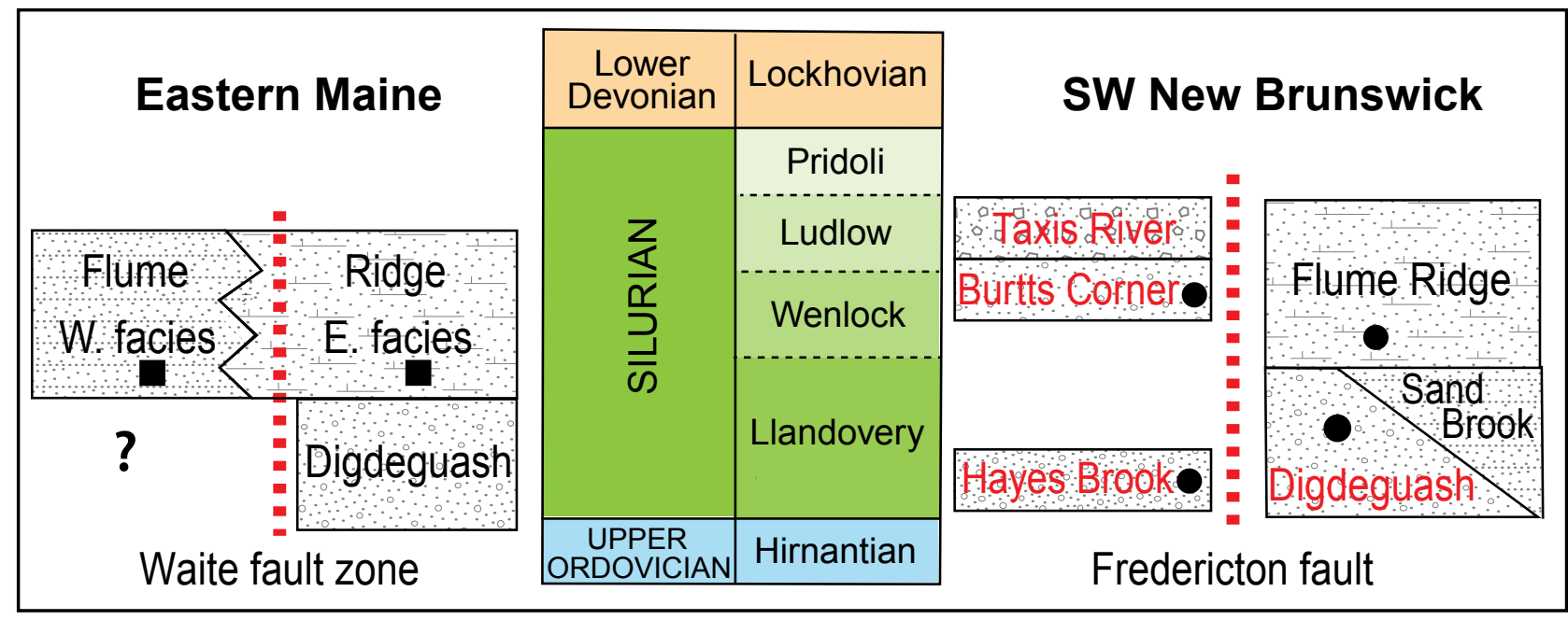

Figure 13. Stratigraphy of the Fredericton trough in eastern Maine and southwestern New Brunswick. Red color indicates formations for which there is fossil age control. Filled squares: units sampled in this study; filled circles: units sampled by Dokken et al. (2018). After Ludman et al. (2017) and Dokken et al. (2018).

listed on recent maps as Silurian-Ordovician(?) (West 2006; Pollock 2012). Results of this study (Fig. 12, AR-1) constrain this age range to Middle Ordovician-latest Silurian, that is, between the prominent youngest detrital zircon peak at 469 Ma on Figure 12 (the Floian-Dapingian boundary) and the age of $422 \pm 2 \mathrm{Ma}$ (Pridoli) from the North Union tonalite gneiss (Tucker et al. 2001) that intruded the Appleton Ridge Formation. It is noteworthy that Pollock (2012) interpreted the Appleton Ridge as being younger than the Bucksport Formation.

Detrital zircon age spectra for the Appleton Ridge and Digdeguash formations are similar in some ways but differ in others (Fig. 15). The most significant difference is a prominent zircon population in the Appleton Ridge Formation at around $1 \mathrm{Ga}$ (Fig. 15), suggesting a source that apparently did not contribute to the Digdeguash Formation. Both have zircon populations at around $465 \mathrm{Ma}$ and $600 \mathrm{Ma}$, suggesting common sources - most likely Miramichi volcanic rocks and peri-Gondwanan sources, respectively - but in different proportions. Additional data are needed to determine whether these differences demonstrate that the Appleton Ridge and Digdeguash formations are not equivalent or that the differences are the result of bias in the zircon grains dated.

\section{Central Maine/Aroostook-Matapedia basin}

Samples were collected from several unfossiliferous sandstone units in the CMAM basin (Fig. 3). Osberg (1988) concluded that the stratigraphic succession in the axial part of the basin near Waterville ( $W$ in Fig. 3 ) is a "sandwich" in which the thin-bedded, dominantly pelitic Waterville Formation is overlain (Mayflower Hill) and underlain (Hutchins Corner) by similar thick-bedded, variably calcareous sandstone units (Table 2). The Waterville Formation contains middle Silurian (Wenlock) graptolites (Ruedemann, cited in Perkins and Smith 1925) and early Silurian (Llandovery) trace fossils (Orr and Pickerill 1995).

Where sandstone is demonstrably younger than the Waterville Formation, Marvinney et al. (2010) recommended that the name Mayflower Hill Formation be used, following Osberg's (1968) original name. Three samples met this condition and are assigned to the Mayflower Hill Formation. Two lie in the same outcrop belt, demonstrably above a Waterville Formation equivalent (Smyrna Mills Formation) $\mathrm{MH}-1$ east of Lincoln ( $L$ on Fig. 3 ), and $\mathrm{MH}-3$ at Howland dam southwest of Lincoln. MH-2 was collected $5 \mathrm{~m}$ above basal black phyllite at the contact with the underlying Waterville Formation near the eponymous Mayflower Hill in Waterville $(W)$ (Stop 5 of Ludman and Osberg 1987). Osberg (1988) named the sandstone below the Waterville Formation the Hutchins Corner Formation, and HC-1 was collected from rocks interpreted as the Hutchins Corner Formation from Freedom village, Maine, at the east edge of the belt.

Where the position of a sandstone unit relative to the Waterville Formation is uncertain, or where the Waterville is absent, as in the broad swath of sandstone between Waterville and the Miramichi terrane (Fig. 3), Marvinney et al. (2010) recommended using the less specific term Vassalboro Group for the unit (Table 2). One sample meets this criterion and is designated as Vassalboro Group, undifferentiated (VG-1) in this paper and Appendices A and B.

Two samples of rocks mapped as the Madrid Formation (MA-1, MA-2) were collected in the northern part of our study area to explore possible differences between detrital zircon age spectra from the early and late stages of CMAM sedimentation. Their assignment to the Madrid is highly probable but they are separated by other units from known Madrid belts to the west on which the stratigraphic succession is based (Osberg et al. 1985).

The small number of zircon grains that yield the youngest 

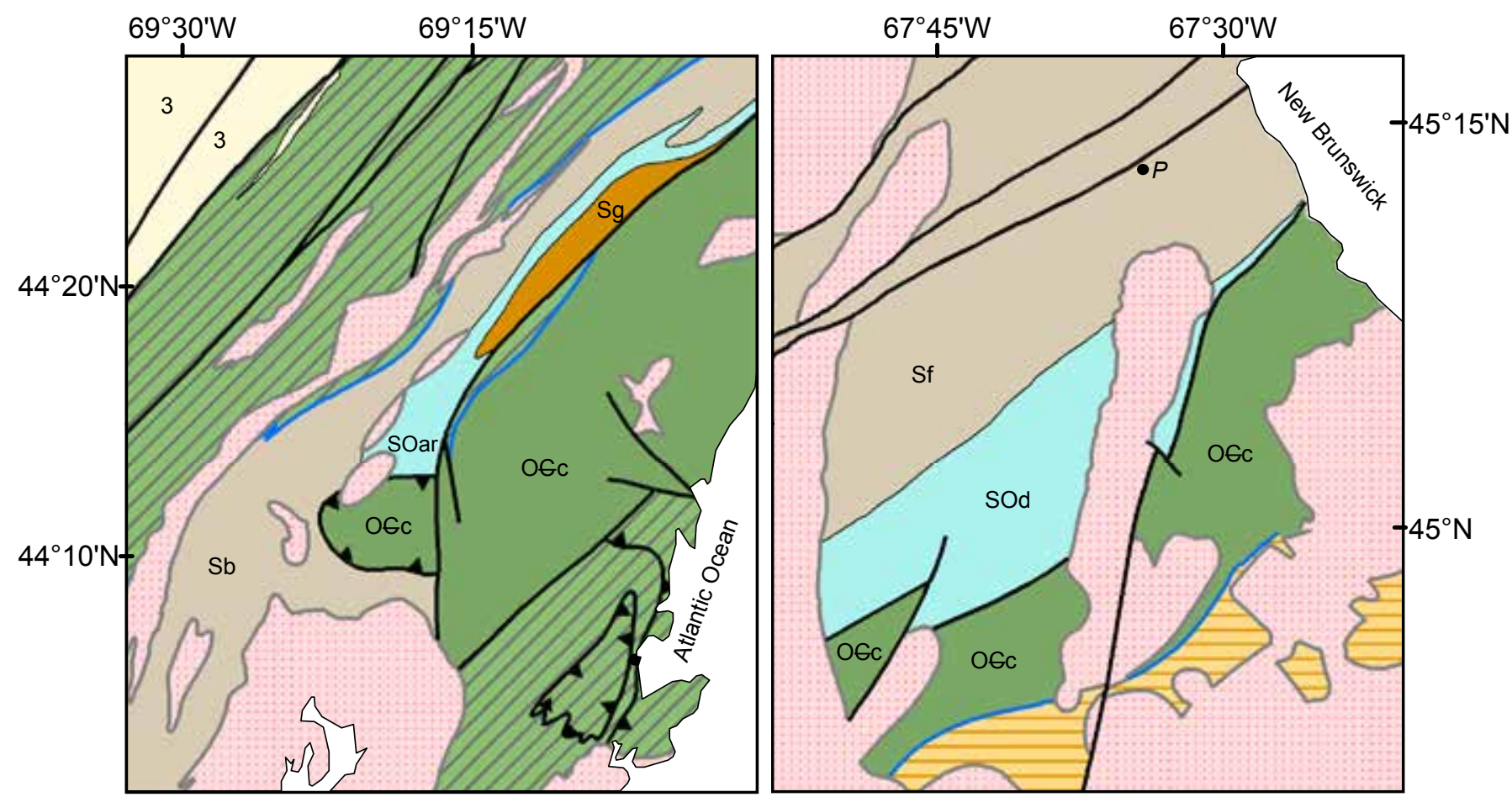

\begin{tabular}{|c|c|}
\hline & Plutons, undifferenti \\
\hline Siluria & \\
\hline 3 & Vassalboro Group \\
\hline $\mathrm{Sb}$ & Bucksport Fm \\
\hline SOar & Appleton Ridge Fm \\
\hline $\mathrm{Sg}$ & Ghent Phyllite \\
\hline pre-L & ate Ordovician \\
\hline $\mathrm{OEC}$ & Cookson Group \\
\hline & Undifferentiated \\
\hline
\end{tabular}
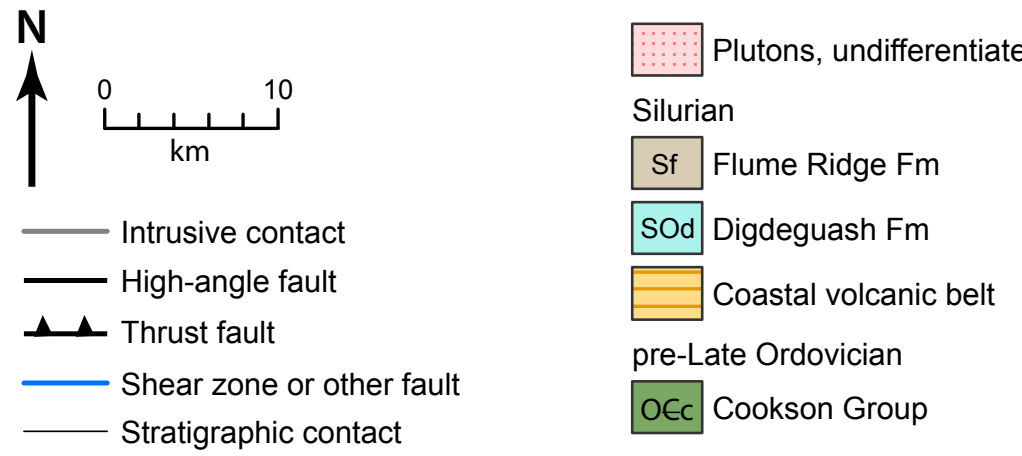

OCC Cookson Group

Figure 14. Comparison of stratigraphic relationships at the east side of the Fredericton belt. The lithologic sequence of Bucksport-Appleton Ridge-Cookson Group in south-central Maine (left) is similar to that of Flume Ridge-DigdeguashCookson Group in eastern Maine (right). Geology adapted from Osberg et al. (1985); Tucker et al. (2001); Ludman and Berry (2003); West (2006); Pollock (2012); and Berry et al. (2016.)

ages is insufficient for determining definite maximum ages in most CMAM samples without further analyses, but their general temporal distribution is suggestive, as shown in Figure 16. Even though the $1 \sigma$ errors reported in Appendices $\mathrm{C}$ and D span the short middle and late stages of the Silurian (see Appendix A), it is likely that the Madrid, Mayflower Hill, Hutchins Corner, and undifferentiated Vassalboro Group samples are, indeed, Silurian. If additional dates in the future corroborate those obtained in this study, all the sampled CMAM rocks would be younger than the Waterville Formation fossils. This result might be problematic in particular for the Hutchins Corner sample (HC-1) which is currently interpreted to be stratigraphically below the Waterville (Osberg 1988). If further detrital zircon work con- firms it to be Wenlock, then its relation to the Llandovery fossil age of the Waterville will need to be revisited.

\section{DISCUSSION}

\section{Provenance}

The provenance of stratigraphic units examined in this study, by definition the birthplace or origin of the deposited material, has two components: the immediate source(s) from which the sediment containing zircon was eroded, transported, and deposited in CMAM or the Fredericton trough, and the ultimate source where the zircons crystallized, 


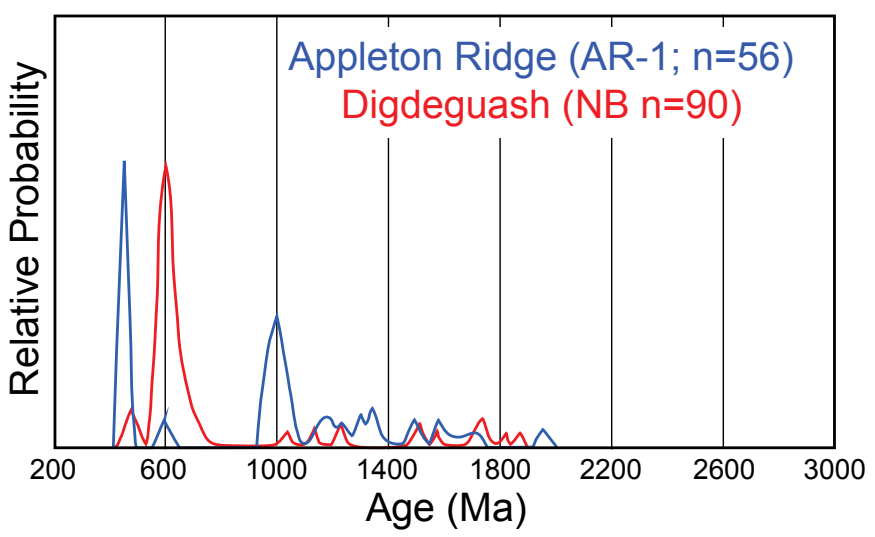

Figure 15. Comparison of Digdeguash (Dokken et al. 2018) and Appleton Ridge (this study) detrital zircon age spectra.

e.g., Amazonia, West Africa, Avalonia. While plutonic and volcanic zircons directly date the times of their crystallization, detrital zircons from a single sandstone may have been recycled from multiple sources whose ages span billions of years. Interpreting the immediate provenance of the rocks in this study is further complicated by the fact that some zircon grains may not have been recycled, but rather deposited directly from pyroclastic volcanic eruptions.

Interpretation of the immediate source of detrital zircons must take into account not only their age spectra but, wherever possible, sedimentologic and lithofacies evidence for the sediment source. There is strong evidence for the immediate source of the cover rock sediment in CMAM (Ludman et al. 2017) and the Fredericton trough (Fyffe 1995), but lacking that evidence for the basement rocks, it is only possible to speculate about their ultimate provenance by comparing their detrital zircon barcodes with those of potential source terranes.

\section{Immediate source of CMAM and Fredericton trough sediment}

Several lines of evidence indicate that most CMAM and Fredericton sediment was recycled from Ganderian sources with little input from external terranes. First, the Miramichi and several other Ganderian basement terranes in Maine were emergent highlands by the late Ordovician (Hirnantian) immediately after accretion of the main body of Ganderia to Laurentia, and were clearly sources of sediment for both CMAM (Bradley and Hanson 2002; Bradley and O'Sullivan 2016; Hopeck 1998; Pankiwskyj et al. 1976) and the Fredericton trough (Fyffe 1995; Ludman et al. 2017).

Second, although the leading edge of Ganderia had docked with Laurentia by the late Ordovician (van Staal et al. 2009), there would have been significant obstructions during the early Silurian to eastward transport of Laurentian sediment to the two depocenters. To reach CMAM, Laurentian sediment would have had to traverse the deep-water Connecticut Valley-Gaspé trough (Tremblay and Pinet
2005, 2016) and bypass the exhumed Boundary Mountains, Munsungun, and Weeksboro-Lunksoos Lake basement terranes. To reach the Fredericton trough, the sediment would have had to traverse the entire deep-water CMAM and then bypass the Miramichi terrane (Ludman et al. 2017). Tightly folded rocks of CMAM today span a width of $160 \mathrm{~km}$, but the undeformed depocenter was at least three to five times wider (Bradley et al. 2000) and would have been a formidable barrier to transport of Laurentian sediment.

It would also have been difficult for detritus to reach the Fredericton trough or CMAM from a peri-Gondwanan source southeast of Ganderia (most likely Avalonia). Starting at about $430 \mathrm{Ma}$, that sediment would have had to traverse the Eastport-Mascarene arc-trench system created by subduction of oceanic lithosphere that separated Avalonia from composite Laurentia + Ganderia (Llamas and Hepburn 2013).

In the absence of external sources, Ganderian basement terranes were most likely the primary sources of CMAM and Fredericton sediment. Hopeck (1998) demonstrated that exhumed Miramichi basement contributed sediment to CMAM in Maine by Hirnantian times, just a few kilometres from the New Brunswick border. It would therefore have been available as a source for the Fredericton trough immediately to the southeast as proposed by Fyffe (1995).

The updated geologic map of eastern and east-central Maine (Fig. 3) shows that samples FR-1, FR-2, and AR-1 were deposited in the Fredericton trough. Significant zircon populations in these rocks between ca. 475 and $455 \mathrm{Ma}$ and ca. 422 and $435 \mathrm{Ma}$ are interpreted to have been derived from two volcanic episodes. The older group corresponds to eruptions in the Popelogan arc and Tetagouche back-arc basin early in the evolution of Ganderia as described above (Wilson et al. 2015). Their recycling into the cover rocks is evidenced by abundant Miramichi volcanic clasts in both CMAM (Hopeck, 1998; Ludman et al. 2017) and the Fredericton trough (Fyffe 1995), and the $469.3 \pm 4.6 \mathrm{Ma}$ age of the Olamon Stream lava reported here.

The younger group was interpreted above as having come directly (i.e., not recycled) from Silurian pyroclastic eruptions in the Eastport-Mascarene volcanic arc. This continental arc formed by melting of, and deposition on, Ganderian lithosphere during westward subduction of a seaway separating Avalonia from composite Laurentia + Ganderia (Llamas and Hepburn 2013). Thus, although they are the product of the Acadian orogenic cycle, these zircons, like those of the older group, are Ganderian.

\section{An alternate explanation for the Fredericton trough}

Dokken et al. (2018) reached different conclusions about the Fredericton trough, most importantly that (a) the Miramichi terrane was not exhumed until Wenlock times; (b) there is no peri-Gondwanan debris in the northern part of the Fredericton trough; and (c) Laurentian sediment is abundant in all units in the northern part of the Fredericton trough and overwhelmed peri-Gondwanan sediment in the 


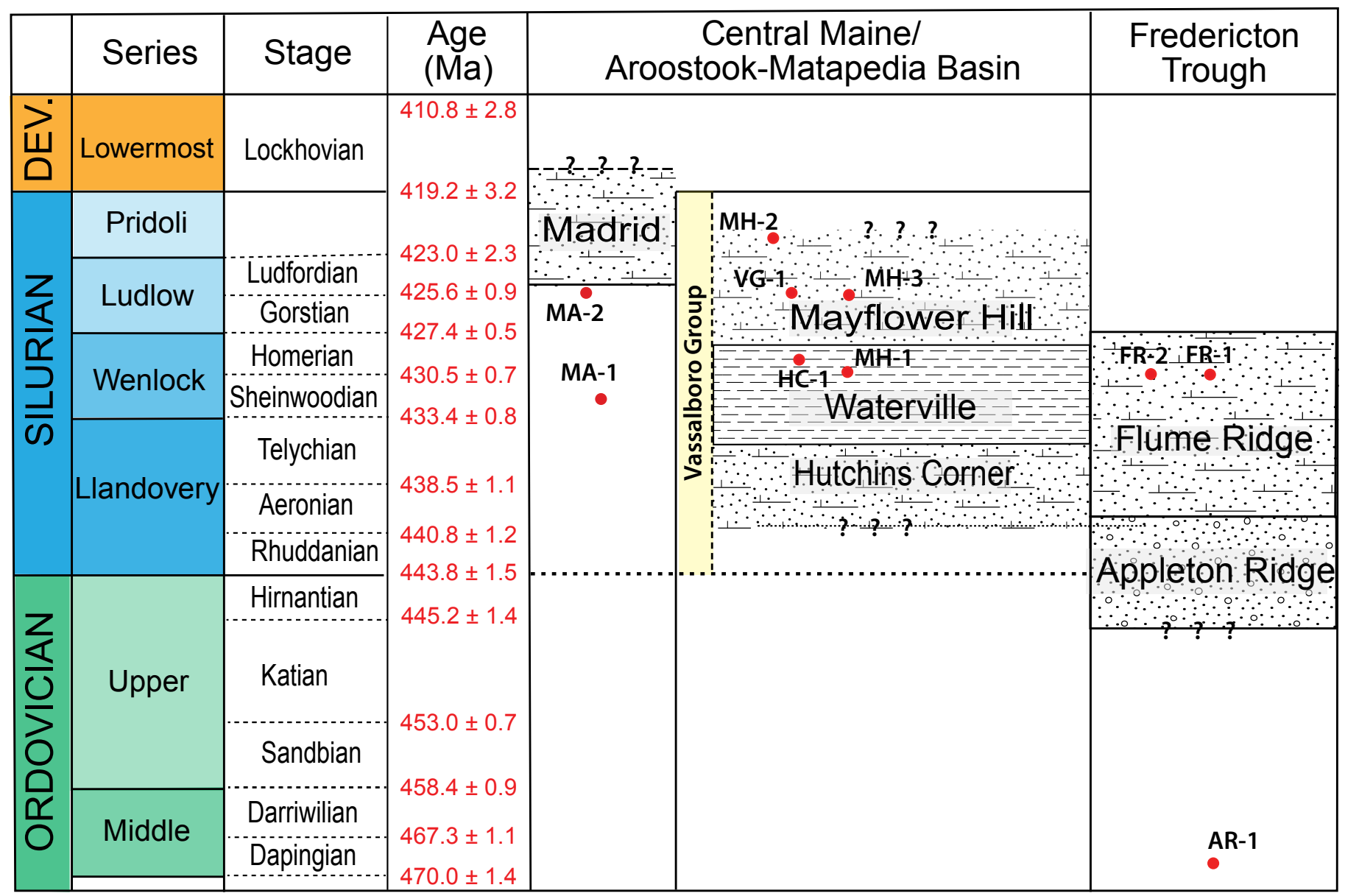

Figure 16. Ages of youngest cover rock zircons compared with previously interpreted stratigraphic ages of the formations from which they were collected.

southern part by the middle Silurian.

Evidence cited above contradicts these assertions and in addition:

(a) Dokken et al. (2018) reasoned that the Miramichi terrane could not have been a sediment source because it was undergoing deep crustal, high-grade metamorphism during late Ordovician to early Silurian subduction (van Staal et al. 2008) and was not exhumed until Wenlock time. The timing and intensity of Miramichi metamorphism in northern New Brunswick are not in question, but neither can be applied to the full $>350 \mathrm{~km}$ extent of the terrane. The entire Maine portion of the Miramichi terrane experienced no greater than lowest greenschist conditions during all late Ordovician through Devonian deformation events. Thus, while the northernmost Miramichi terrane was being subducted to deep crustal levels (van Staal et al. 2008), the southern part, from at least the Maine-New Brunswick border to Greenfield, was at very shallow crustal levels, and, as shown above, had been exhumed well before the Wenlock

(b) Dokken et al. (2018) reported that peri-Gondwanan detritus is absent from the Rhudannian Hayes Brook Formation and arrived later in the younger Burtts Corner and Flume Ridge formations, signaling exhumation of the Miramichi terrane. However, they attributed the dominant
465-480 Ma zircon populations in all three formations to distant peri-Laurentian arcs rather than to local Ganderian (i.e., peri-Gondwanan) Popelogan and Tetagouche eruptions. For reasons given above, a Laurentian or peri-Laurentian source is unlikely.

(c) As explained above, it is unlikely that Laurentian sediment contributed significantly to the Fredericton trough at any time in its history.

\section{Immediate source of basement rocks}

Basement rock barcodes contain zircon populations at ca. $800 \mathrm{Ma}$ (BL-2, KM-1) and ca. 2.0 to $2.5 \mathrm{Ga}$ (BL-2, BM-1, KM-1) that are absent from or rare in the cover rocks (Fig. 5 ). These suggest a source or sources not tapped by the younger strata, but without the sedimentologic evidence that clarified the source of the cover rock sediment, it is impossible to distinguish between the immediate and ultimate provenance of these basement zircon populations.

\section{Ultimate source/tectonic fingerprint of the Ganderian detrital zircons}

Detrital zircon age spectra have become an important 
tool for identifying terranes formed during the breakup of Rodinia and reconstructing where in Rodinia those fragments originated. Most northern Appalachian studies focus on distinguishing Laurentia from Ganderia, Avalonia, and Meguma, the other Rodinian fragments with which it was reunited during the Paleozoic (Dorais et al. 2014; McWilliams et al. 2010; Wintsch et al. 2007). Others seek to determine whether Ganderia broke off directly from Gondwana or from Amazonia (van Staal et al. 2012; Fyffe et al. 2009). Interpretations are based on matching local and regional detrital zircon age spectra with ages of tectonic, plutonic, and volcanic zircon-producing events unique to individual fragments (e.g., Nance et al. 2008).

Figure 17 compares the Ganderian signature obtained from basement and cover rocks in this study with the compilation by Nance et al. (2008) of events in the eastern Laurentian, Amazonian, and West African cratons. The continuous range of zircon ages between $600 \mathrm{Ma}$ and $1.8 \mathrm{Ga}$ from the study area is most similar to the compilation of Amazonian events (Nance et al. 2008), supporting the earlier conclusions of van Staal et al. (2012) and Fyffe et al. (2009). However, the viability of a West African connection has been raised by recently reported detrital zircon ages from the Mauritanide orogen (Bradley 2018) indicating similarities with Amazonian events.

\section{Timing of orogenic events in eastern Maine}

\section{Late Ordovician}

Although the ages reported here from the Miramichi and St. Croix terranes improve understanding of stratigraphy and provenance of the basement rocks, they contribute little to refining the ages of Ordovician orogenic events. Deformation of the St. Croix terrane occurred between ca. 453 and $442 \mathrm{Ma}$, bracketed between middle Caradocian fossils in the Kendall Mountain Formation (Fyffe and Riva 1990) and Upper Rhudannian fossils in the Digdeguash Formation (ages after Cohen et al. 2013).

Deformation of the Miramichi terrane in Maine occurred at about the same time (between ca. 453 and $445 \mathrm{Ma}$ ), bracketed between deposition of "Llanvirnian to Caradocian" black shale in the Stetson Mountain Formation (Larrabee et al. 1965) and Hirnantian limestone of the Carys Mills Formation (Rickards and Riva 1981). The 469.3 \pm 4.6 Ma zircon age of the Olamon Stream lava suggests a range for eruption of the upper volcanic component of the Miramichi suite (ca. 469-453 Ma) but does not refine the timing of Late Ordovician deformation.

\section{Silurian}

The $\mathrm{U}-\mathrm{Pb}$ zircon age for the post-Salinic Pocomoonshine gabbro-diorite $(421.9 \pm 2.4 \mathrm{Ma})$ overlaps the $423 \pm 3 \mathrm{Ma}$ ${ }^{40} \mathrm{Ar} /{ }^{39} \mathrm{Ar}$ hornblende cooling age of West et al. (1992) and is the minimum age of the Salinic event. This is consistent with the ca. 450-430 Ma span proposed for the Salinic event in New Brunswick (Wilson et al. 2015), but the presence of ca. 431 and $433 \mathrm{Ma}$ zircon grains suggests that the Salinic might have lasted somewhat longer in eastern Maine. The overlap of the zircon crystallization and hornblende cooling ages shows that the pluton cooled rapidly at shallow crustal levels.

\section{Transition from Late Ordovician to Silurian tectonism}

Detrital zircon ages of the cover rocks provide insight into conditions between Late Ordovician and Silurian (Salinic) tectonism. An enormous volume of turbidites was deposited during this interval in the area between western Maine and central New Brunswick (Ludman et al. 2017). Detrital and plutonic zircon ages suggest that the transition from post-Middle Ordovician sedimentation to Salinic deformation in the later part of that time span is best described as "busy", with several events in a short time span: (1) crystallization of ca. $430 \mathrm{Ma}$ zircon during Eastport-Mascarene volcanism; (2) incorporation of the zircon in the kilometres-thick Flume Ridge Formation; (3) lithification of a thick pile of Flume Ridge + Sand Brook + Digdeguash turbidites; (4) intense isoclinal folding; and (5) post-folding emplacement of the Pocomoonshine gabbro-diorite at $(421.9 \pm 2.4 \mathrm{Ma})$.

\section{Origin of the Fredericton trough and CMAM}

Several tectonic settings have been proposed for the CMAM basin and Fredericton trough. Bradley and Hanson (2002) described CMAM as an Acadian foreland basin, but Bradley and O'Sullivan (2016) expressed uncertainty as to whether sediments were deposited on oceanic or continental crust. Tucker et al. (2001) envisaged an extensional setting for CMAM, describing cover rock basins as graben and the pre-Middle Ordovician source areas as horsts. Tremblay and Pinet (2005) also proposed an extensional origin for the Connecticut Valley-Gaspé trough, northwesternmost Ganderian cover rock basin (Fig. 1), and suggested a similar origin for CMAM (which they called the Merrimack basin).

The Fredericton trough has been described variably as a remnant of oceanic crust following Late Ordovician accretion (Park and Whitehead 2003), a post- "Taconian" (= postLate Ordovician) successor basin (Williams 1979), and a Salinic fore-arc basin or foredeep associated with westward subduction that closed a back-arc basin on the outboard margin of Ganderia (Fyffe et al. 2011; Wilson et al. 2015).

Recent tectonic models concluded that all oceanic crust in the study area had been consumed by Late Silurian-Early Devonian accretion of Ganderia to Laurentia (e.g., Fyffe et al. 2011; Wilson et al. 2015). These models proposed two stages of subduction: Late Ordovician closing of the Iapetus ocean followed by Salinic closing of a back-arc basin associated with the Tetagouche volcanic arc in New Brunswick. Timing of initial sedimentation in the two depocenters and their size and geometry provide a means to test these hypotheses. 


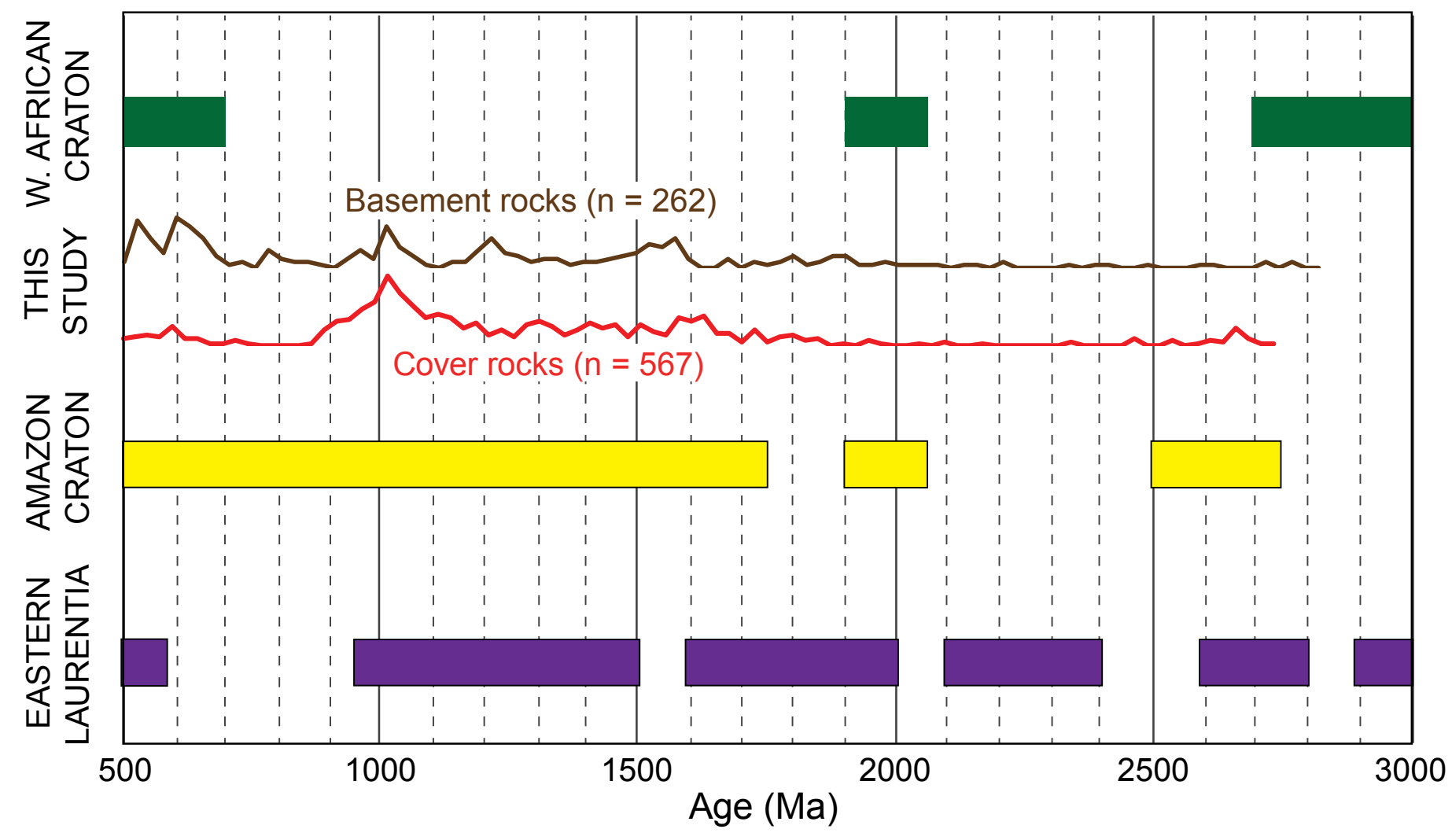

Figure 17. Detrital zircon age distribution in basement and cover rocks compared with timing of zircon-producing events in eastern Laurentia, Amazonia, and the West African craton. Modified after Nance et al. (2008).

\section{Fredericton trough}

Fossil and geochronologic evidence indicate that turbidite sedimentation in the Fredericton trough began shortly after Late Ordovician deformation, by the Rhudannian or earlier, and continued until Salinic deformation and emplacement of the Pocomoonshine gabbro-diorite at ca. 422 Ma. In the eastern part of the study area, the Fredericton trough was separated from CMAM during Silurian time by a Miramichi highland that shed sediment into both basins (Ludman et al. 2017). This timing is compatible with the Salinic foredeep model cited above, with subsidence of the Fredericton trough caused by tectonic loading associated with thrust sheets of the Brunswick subduction complex (Fyffe et al. 2011; Wilson et al. 2015). This model is also supported by estimated pre-deformation width and lateral extent of the Fredericton trough comparable with those of modern foredeep basins (Allen and Homewood 1986; DeCelles 2012). In addition, estimates of Fredericton trough sedimentation rates are comparable to those of modern deep marine depocenters based on published thicknesses of Fredericton trough formations, decompacted following curves of Kominz et al. (2011) and the time frame discussed above.

\section{Central Maine/Aroostook-Matapedia basin}

Sedimentation began in CMAM at approximately the same time as in the Fredericton trough (Ludman et al. 2017), but its origin is less certain and its evolution was more complex, with two distinct phases of sedimentation. The initial phase of deep-water turbidite sedimentation began on both west and east flanks of the basin by late Ordovician time, as evidenced by the Quimby Formation in western Maine (Bradley and O'Sullivan 2016) and Carys Mills (Hirnantian), Daggett Ridge, and Mill Priviledge Brook formations in eastern Maine (Ludman et al. 2017). The eastern flank of the CMAM basin in mid-coastal Maine is unknown due to truncation by faulting (Tucker et al. 2001).

Initial CMAM sedimentation thus preceded the onset of Acadian subduction and deformation by millions of years, so the CMAM basin could not have originated as an Acadian foreland basin as is commonly proposed (e.g., Bradley and O'Sullivan 2016; Hatcher 2010). Tremblay and Pinet $(2005,2016)$ suggested that the northwesternmost Ganderian cover rock basin, the Connecticut Valley-Gaspé trough (Fig. 1), probably formed by intraplate extension and proposed a similar origin for the western part of the CMAM basin ("Merrimack trough" in their paper).

The size of the CMAM basin is also problematical for a foreland basin. Although its current $\sim 160 \mathrm{~km}$ deformed width is comparable to that of modern deep marine foreland basins such as the Hidaka Trough (northern Japan; Noda et al. 2013) and the Western Taiwan foreland basin (Yu and Chou 2001), CMAM experienced intense Acadian shortening. Bradley et al. (2000) estimated that its current 
outcrop width is only $30 \%$ of its undeformed extent but did not consider (1) an episode of recumbent folding, (2) two generations of thrusting now recognized in the basin (Tucker et al. 2001), (3) blind thrusts imaged in seismic reflection profiling (Doll et al. 1996), nor (4) thrusting of the east flank of the basin over its Miramichi source (Ludman et al. 2017). The degree of crustal shortening was probably greater than $70 \%$ and CMAM was possibly as much as $800-1000 \mathrm{~km}$ wide, far wider than modern marine foreland basins.

The second sedimentary regime began in the Late Silurian and continued through the Early Devonian (Bradley et al. 2000), adding approximately $9 \mathrm{~km}$ of sediment to the CMAM basin after sedimentation had ceased in the Fredericton trough (Bradley and O'Sullivan 2016). Cogent paleocurrent, paleontological, and geochronological evidence show that the CMAM basin had become an Acadian foredeep during this time span, and that its sediment was sourced uniformly from an Acadian forebulge to the southeast (Bradley et al. 2000).

\section{Recognition of Ganderia in southern New England}

Detrital zircon barcodes have been used to distinguish intensely metamorphosed Laurentian, Ganderian, and Avalonian terranes in southern New England, where the northern Appalachian orogen is telescoped to a fraction of its width in the study area (Fig. 2) (e.g., Dorais et al. 2014; Walsh et al. 2007; Wintsch et al. 2007). If our interpretation of provenance is correct, the basement rock barcodes (Fig. 5b) represent an unadulterated Ganderian signature that should be useful in identifying the terrane where its presence and/or extent are uncertain. Cover rock barcodes (Fig. 5a) should also be useful, despite their modification by addition of $\mathrm{Si}$ lurian volcanic zircons.

\section{CONCLUSIONS AND FUTURE DIRECTIONS}

\section{Constraints on ages and correlation of stratified rocks}

1. Ages of volcanic zircon date for the first time the uppermost (volcanic) formation in the Miramichi basement succession in Maine (469.3 $\pm 4.6 \mathrm{Ma})$, and a tuff horizon near the base of the Kendall Mountain Formation of the St. Croix basement succession $(477.4 \pm 3.7 \mathrm{Ma})$. These ages constrain times of deposition of unfossiliferous sandstone units in the CMAM and Fredericton cover successions.

2. The presence of Silurian detrital zircon that is only slightly older than the ages of the host cover rocks suggests derivation from Silurian volcanism, probably of the Eastport-Mascarene volcanic belt.

3. The Appleton Ridge Formation apparently lacks the Silurian detrital zircon component present in the other cover rocks, suggesting that it was deposited prior to that volcanism.

4. Proposed correlation of the Appleton Ridge and Digdeguash formations remains unresolved. Both units were intruded by ca. 422 Ma plutons, lack Silurian detrital zircon, and have similar populations of early Paleozoic detrital zircon. However, possible differences in provenance and difficulty in assessing different proportions of zircon age populations because of the limited number of analyzed grains preclude a definite statement about their correlation.

\section{Provenance of stratified rocks}

1. Detrital zircon age spectra combined with tectonic and lithofacies models indicate that recycled Ganderian basement was the dominant source material for the cover rocks.

2. Populations of zircon found in the basement rocks but not in the cover successions, suggest early Paleozoic sediment sources that were not tapped by the cover rocks.

3. Comparison of detrital zircon age distribution with ages of zircon-producing events from Rodinian cratonic fragments suggests that Ganderia was derived from Amazonia.

\section{Tectonic implications}

1. Salinic deformation in eastern Maine and southwestern New Brunswick is bracketed between the $421.9 \pm 2.4 \mathrm{Ma}$ $\mathrm{U}-\mathrm{Pb}$ zircon crystallization age of the Pocomoonshine gabbro-diorite and the ca. $431 \mathrm{Ma}$ age of the youngest zircons in the Flume Ridge Formation that it intrudes. The overlap of the crystallization age with a $423 \pm 3$ Ma hornblende cooling age (West et al. 1992) shows that the pluton cooled rapidly at shallow crustal depths.

2. Proposed evolution of the Fredericton trough as a Salinic foredeep is supported by detrital zircon ages and comparison of pre-deformation basin dimensions and estimated sedimentation rates with those of modern analogues.

3. Initial sedimentation in the Central Maine/AroostookMatapedia basin pre-dated onset of Acadian subduction, proving that the basin did not originate as an Acadian foreland basin. A second phase of sedimentation was Acadian, with a northwest-migrating forebulge shedding sediment diachronously into a CMAM foredeep.

\section{Future directions}

1. Expanded detrital zircon dating: Ages of the youngest zircon grains present in most samples are based on too few grains to be statistically meaningful. Additional dating of grains separated during this study by LA-ICPMS is planned to address this issue. Also, in view of the analytical error associated with SHRIMP analysis vis a vis the short time span of Silurian stages, more precise TIMS dating of screened grains would provide precision comparable to that associated with the most recent chronostratigaphic charts and better constrain the maximum ages of the formations sampled.

Detrital zircon studies have answered some questions and raised new ones on the west (Bradley and O'Sullivan 2016) and east (this study) flanks of the CMAM basin but similar work is needed in the axial and western intermediate facies, 
particularly from sites that yielded the rare fossils which provide ages for formations in those facies.

2. Better fossil age control: The low regional metamorphic intensity in and north of the study area suggests that a search for acritarchs and spores may be fruitful. A pilot feasibility study is under way involving units from the Miramichi, Fredericton, and CMAM successions.

3. More information about the origin of the CMAM basin: Researchers in New Brunswick have deciphered a complex tectonic/stratigraphic history from detailed mapping and geochemical studies of the Popelogan-Tetagouche arc/backarc basin system (e.g., Wilson et al. 2015; van Staal et al. 2016). There is a pressing need for modern interdisciplinary work of this type in northern Maine, where the WeeksboroLunksoos and Munsungun arc terranes are more broadly exposed than the Popelogan (Osberg et al. 1985), and were emergent source areas within the CMAM basin.

\section{ACKNOWLEDGMENTS}

Several individuals have contributed substantially to this project. Gary Aldaz and Jimi Rabin were eager and energetic field assistants during mapping in the Bowers Mountain and Bottle Lake quadrangles and provided the muscle that collected some of the Miramichi samples. We thank Chris Gerbi for generously donating zircon separates from the Appleton Ridge Formation. We are indebted to Dwight Bradley, Chris Hepburn, and John Waldron who generously shared unpublished detrital zircon data and preliminary manuscripts and offered suggestions that guided interpretations presented above. We may not always agree on those interpretations but these collegial discussions enriched our understanding of regional relationships. Discussions with Wally Bothner, Bob Wintsch, and the late Arthur Hussey about their work in southwestern Maine helped place our results in a broader regional context. Comments on early versions of this paper by Sandra Barr, Bill Devlin, Chris Hepburn, Justin Strauss, Greg Walsh, Bob Wintsch, and two anonymous reviewers significantly improved both the scientific conclusions and readability of the manuscript. The Maine Geological Survey, guided by State Geologist Robert Marvinney, provided logistic and moral support, and Amber Whittaker drafted the updated geologic maps in Figures 3 and 14. We are grateful to Renee Pillers of the U.S.G.S. for help with difficult mineral separa-tions, image preparation, and SHRIMP-RG analysis.

\section{REFERENCES}

Allen, P. and Homewood, P. (Editors). 1986. Foreland Basins. International Association of Sedimentologists, Special Publication No. 8, Blackwell Scientific Publications, $453 \mathrm{pp}$.

Berry, H., West, D., and Burke, W. 2016. Bedrock relationships along the Sennebec Pond fault: A structural puzzle, a stratigraphic enigma, and a tectonic riddle. In Guide- book for field trips along the Maine coast from Maquoit Bay to Muscongus Bay. Edited by $\mathrm{H}$. Berry and D. West. New England Intercollegiate Geologic Conference, pp. 43-70.

Black, L., Kamo, S., Allen, C., Davis, D., Aleinikoff, J., Valley, J., Mundil, R., Campell, I., Korsuch, R., Williams, I., and Foudoulis, C. 2004. Improved ${ }^{206} \mathrm{~Pb} /{ }^{238} \mathrm{U}$ microprobe geochronology by the monitoring of a trace-element-related matrix effect; SHRIMP, ID-TIMS, ELA-ICP-MS and oxygen isotope documentation for a series of zircon standards. Chemical Geology, 205(1-2), pp. 115-140. https:// doi.org/10.1016/j.chemgeo.2004.01.003

Bradley, D. 2018. Mesoproterozoic detrital zircons from Neoproterozoic strata in West Africa and implications for Appalachian terranes. In 53nd Northeastern Annual Section Meeting, Burlington, Vermont, March 18-20, 2018. Geological Society of America Abstracts with Programs, 50, No. 2. https://doi.org/10.1130/abs/2018NE-310858

Bradley, D. and Hanson, L. 2002. Paleocurrent analysis of a deformed Devonian foreland basin in the Northern Appalachians, Maine, USA. Sedimentary Geology, 148, pp. 425-447. https://doi.org/10.1016/S0037-0738(01)00161-0

Bradley, D. and O'Sullivan, P. 2016. Detrital zircon geochronology of pre- and syncollisional strata, Acadian orogen, Maine Appalachians. Basin Research (2016), pp. 1-20. https://doi.org/10.1111/bre.12188

Bradley, D., Tucker, R., Lux, D., Harris, A., and McGregor, D. 2000. Migration of the Acadian orogen and foreland basin across the Northern Appalachians of Maine and adjacent areas. United States Geological Survey Professional Paper 1624, 51 pp. https://doi.org/10.3133/pp1624

Cohen, K., Finney, S., Gibbard, P., and Fan, J.-X. 2013. The ICS International Chronostratigraphic Chart (updated 2017). Episodes 36, pp. 199-204.

Cumming, L. 1967. Geology of the Passamaquoddy Bay region, Charlotte County, New Brunswick. Geological Survey of Canada, Paper 65-29, 36 pp. https://doi. org/10.4095/100976

DeCelles, P. 2012. Foreland basin systems revisited: Variations in response to tectonic settings. In Tectonics of Sedimentary Basins: Recent Advances. Edited by C. Busby and A. Pérez. Blackwell Publishing, Ltd., pp. 405-426. https:// doi.org/10.1002/9781444347166.ch20

Dickinson, W. and Gehrels, G. 2009. Use of U-Pb ages of detrital zircons to infer maximum depositional ages of strata: A test against a Colorado Plateau Mesozoic database. Earth and Planetary Science Letters, 288, pp. 115-125. https://doi. org/10.1016/j.epsl.2009.09.013

Dokken, R., Waldron, J., and Dufrane, A. 2018. Detrital zircon geochronology of the Fredericton Trough, New Brunswick, Canada: Constraints on the Silurian closure of remnant Iapetus Ocean. American Journal of Science, 318, pp. $684-$ 725. https://doi.org/10.2475/06.2018.03

Doll, W., Domoracki, J. Costain, J. Coruh, C, Ludman, A., and Hopeck, J. 1996. Seismic reflection evidence for the evolution of a transcurrent fault system: Norumbega fault zone, Maine. Geology, 24, pp. 251-254. https://doi. 
org/10.1130/0091-7613(1996)024<0251:SREFTE $>2.3$. $\mathrm{CO} ; 2$

Dorais, M., Wintsch, R., Kunk, M., Aleinikoff, J., Burton, W., Underdown, C., and Kerwin, C. 2014. P-T-t conditions, $\mathrm{Nd}$ and $\mathrm{Pb}$ isotopic compositions, and detrital zircon geochronology of the Massabesic Gneiss complex, New Hampshire: Isotopic and metamorphic evidence for the identification of Gander basement, central New England. American Journal of Science, 312, pp. 1049-1097. https:// doi.org/10.2475/10.2012.01

Doyle, R. and Hussey, A. 1967. Preliminary Geologic Map of Maine. Maine Geological Survey, Augusta, Maine, scale 1:500 000 .

Fyffe, L. 1991. Geology of the Flume Ridge-Kedron Stream map areas, New Brunswick. In Project Summaries for 1991, Sixteenth Annual Review of Activities. Edited by S.A. Abbott. New Brunswick Department of Natural Resources and Energy, Mineral Resources, Information Circular 91-2, pp. 12-20.

Fyffe, L. 1995. Fredericton Belt. In Geology of the Appalachian-Caledonian Orogen in Canada and Greenland. $E d-$ ited by $\mathrm{H}$. Williams. Geological Survey of Canada, Geology of Canada, No. 6, pp. 351-354.

Fyffe, L. and Riva, J. 1990. Revised stratigraphy of the Cookson Group of southwestern New Brunswick and adjacent Maine. In New age determinations in the Atlantic provinces. Edited by R. Raeside and S. Barr. Atlantic Geology, 26, pp. 271-276.

Fyffe, L. and Riva, J. 2001. Regional significance of graptolites from the Digdeguash Formation of southwestern New Brunswick. In Current Research 2000. Edited by B.M.W. Carroll. New Brunswick Department of Natural Resources, Minerals and Energy Division, Mineral Resource Report 2001-4, pp. 47-54.

Fyffe, L., Barr, S., Johnson, S., McLeod, M., McNicoll, V., Valverde-Vaquero, P., van Staal, C., and White, C. 2009. Detrital zircon ages from Neoproterozoic and Early $\mathrm{Pa}-$ leozoic conglomerate and sandstone units of New Brunswick and coastal Maine: Implications for the tectonic evolution of Ganderia. Atlantic Geology, 45, pp. 110-144. https://doi.org/10.4138/atlgeol.2009.006

Fyffe, L., Forbes, W., and Riva, J. 1983. Graptolites from the Benton area of west-central New Brunswick and their regional significance. Maritime Sediments and Atlantic Geology, 19, pp. 117-125. https://doi.org/10.4138/1570

Fyffe, L., Johnson, S., and van Staal, C. 2011. A review of Proterozoic to Early Paleozoic lithotectonic terranes in the northeastern Appalachian orogen of New Brunswick, Canada, and their tectonic evolution during Penobscot, Taconic, Salinic, and Acadian orogenesis. Atlantic Geology, 47, pp. 211-248. https://doi.org/10.4138/atlgeol.2011.010

Gates, O. and Moench, R. 1981. Bimodal Silurian and Lower Devonian volcanic rock assemblages in the Machias-Eastport area, Maine. United States Geological Survey Professional Paper 1184, 32 pp. https://doi.org/10.3133/pp1184 Hatcher, R. 2010. The Appalachian orogeny: A brief sum- mary. In From Rodinia to Pangea: The lithotectonic record of the Appalachian region. Edited by R. Tollo, M. Bartholomew, J. Hibbard, and P. Karabinos. Geological Society of America, Memoir 206, pp. 51-69.

Hibbard, J., van Staal, C., Rankin, D., and Williams, H., 2006. Lithotectonic map of the Appalachian orogen, Canada-United States of America. Geological Survey of Canada, Map 2096A, scale 1:1500 000.

Hopeck, J. 1998. Stratigraphy and structural geology of the Wytopitlock and Springfield fifteen-minute quadrangles, eastern Maine; Unpublished PhD dissertation; City University of New York, New York, New York, 160 pp.

Hussey, A., Bothner, W., and Aleinikoff, J. 2010. The tectonostratigraphic framework and evolution of southwestern Maine and southeastern New Hampshire. In From Rodinia to Pangea: The lithotectonic record of the Appalachian region. Edited by R. Tollo, M. Bartholomew, J. Hibbard, and P. Karabinos. Geological Society of America, Memoir 206, pp. 205-230. https://doi. org/10.1130/2010.1206(10)

Hussey, A., Bothner, W., and Thompson, P. 2016. Bedrock geology of the Kittery 1:100 000 quadrangle, southwestern Maine and southeastern New Hampshire. Maine Geological Survey, Bulletin 45, 99 pp.

Kominz, M., Patterson, K., and Odette, D. 2011. Lithology dependence of porosity in slope and deep marine sediments. Journal of Sedimentary Research, 81, pp. 730-742. https://doi.org/10.2110/jsr.2011.60

Larrabee, D., Spencer, C., and Swift, D. 1965. Bedrock geology of the Grand Lake area, Aroostook, Hancock, Penobscot, and Washington counties, Maine. United States Geological Survey, Bulletin 1201-E, 38 pp, with map, scale 1:250 000 .

Llamas, A. and Hepburn, J. 2013. Geochemistry of Silurian-Devonian volcanic rocks in the Coastal Volcanic Belt, Machias-Eastport area, Maine: Evidence for a pre-Acadian arc. Geological Society of America Bulletin, 125, pp. 1930-1942. https://doi.org/10.1130/B30776.1

Ludman, A. 1976. A fossil-based stratigraphy in the Merrimack Synclinorium, central Maine. In Contributions to New England Stratigraphy. Edited by L. Page. Geological Society of America, Memoir 148, pp. 65-78. https://doi. org/10.1130/MEM148-p65

Ludman, A. 1990. Bedrock geology of the Big Lake 15' quadrangle, Maine. Maine Geological Survey Open-File Report 90-26, 22 p., with map scale 1:62 500.

Ludman, A. 1991. Revised stratigraphy of the Cookson Group (St. Croix terrane), eastern Maine and southwestern New Brunswick. In Geology of the Coastal Lithotectonic Block and neighboring terranes, eastern Maine and southern New Brunswick. Edited by A. Ludman. New England Intercollegiate Geological Conference guidebook, pp. 114-132.

Ludman, A. 2013. Closing the gap: Relationships of the Waterville and Aroostook-Matapedia successions. In Guidebook for field trips in north-central Maine. Edited by L. Hanson. New England Intercollegiate Geological Confer- 
ence, pp. 1-14.

Ludman, A. 2018. Preliminary bedrock geology of the Greenfield quadrangle, Maine. Maine Geological Survey, Open-File Map 18-13, scale 1:24000.

Ludman, A. 2017. Multiple deformation of chlorite-grade Late Ordovician to Early Devonian strata in eastern Maine. In 52nd Northeastern Annual Section / 51st North-Central Annual Section Meeting, Pittsburgh, Pennsylvania March 19-21, 2017. Geological Society of America Abstracts with Programs, 49, 2. https://doi. org/10.1130/abs/2017NE-290457

Ludman A. and Berry, H. 2003. Bedrock geology of the Calais 1:100 000 quadrangle, Maine. Maine Geological Survey, Open-File Map 03-97, scale 1:100 000.

Ludman, A. and Hill, M. 1990. Bedrock geology of the Calais 15' quadrangle, Eastern Maine. Maine Geological Survey, Open-File Report 90-27, 32 pp., map scale 1:62 500.

Ludman, A. and Osberg, P. 1987. Structure and stratigraphy of the central Maine turbidite belt in the SkowheganWaterville region. In Northeastern section of the Geological Society of America, Centennial Field Guide, volume 5. Edited by D. Roy. Geological Society of America, pp. 279-283. https://doi.org/10.1130/0-8137-5405-4.279

Ludman, A., Hopeck, J., and Berry, H. 2017. Provenance and paleogeography of post-Middle Ordovician pre-Devonian sedimentary basins on the Gander composite terrane, eastern and east-central Maine: implications for Silurian tectonics in the northern Appalachians. Atlantic Geology, 53, p. 63-85. https://doi.org/10.4138/atlgeol.2017.003

Ludman, A., Hopeck, J., and Brock, P. 1993. Nature of the Acadian orogeny in eastern Maine. In The Acadian Orogeny: Recent Studies in New England, Maritime Canada, and the Autochthonous Foreland. Edited by D. Roy and J. Skehan. Geological Society of America Special Paper 275, pp. 67-84. https://doi.org/10.1130/SPE275-p67

Ludman, A., Lanzirotti, A., Lux, D., and Wang, C. 1999. Constraints on timing and displacement of multiple shearing in the Norumbega fault system, eastern Maine; In Norumbega fault system of the Northern Appalachians. Edited by A. Ludman and D. West, Jr. Geological Society of America Special Paper 331, pp. 179-194. https://doi. org/10.1130/0-8137-2331-0.179

Ludwig, K. R. 1980. Calculation of uncertainties of U-Pb isotope data: Earth and Planetary Science Letters, 46, pp. 212-220. https://doi.org/10.1016/0012-821X(80)90007-2

Ludwig, K.R. 2003. Isoplot/Ex version 3.00. A geochronological toolkit for Microsoft Excel. Berkeley Geochronology Center Special Publication, No. 4, Berkeley, California, $73 \mathrm{pp}$.

Ludwig, K.R. 2009. Squid 2, version 2.50, A user's manual. Berkeley Geochronology Center, Special Publication, No. 5, Berkeley, California, 110 pp.

Marvinney, R., West, D.P., Jr., Grover, T., and Berry, H. 2010. A stratigraphic review of the Vassalboro Group in a portion of central Maine; In Guidebook for field trips in coastal and interior Maine. Edited by C. Gerbi, M. Yates, A. Kelley, and D. Lux. New England Intercollegiate Geo- logical Conference guidebook, pp. 61-76.

McWilliams, C., Walsh, G., and Wintsch, R. 2010. Silurian-Devonian age and tectonic setting of the Connecticut Valley-Gaspé trough in Vermont based on U-Pb SHRIMP analyses of detrital zircons. American Journal of Science, 310, pp. 325-363. https://doi.org/10.2475/05.2010.01

Moench, R. and Pankiwskyj, K. 1988. Geologic map of western interior Maine [with contributions by G. Boone, E. Boudette, A. Ludman, W. Newell, and T. Vehrs]. United States Geological Survey, Miscellaneous Investigations Map I-1692, scale 1:250 000.

Mohammadi, N., Fyffe, L., McFarlane, C., Thorne, K., Lentz, D., Charnley, B., Branscombe, L., and Butler, S. 2017. Geological relationships and laser ablation ICPMS U-Pb geochronology of the Saint George Batholith, southwestern New Brunswick, Canada: implications for its tectonomagmatic evolution. Atlantic Geology, 57, pp. 207-240. https://doi.org/10.4138/atlgeol.2017.008

Nance, D., Murphy, B., Strachan R., Keppie, D., Gutiérrez -Alonso, G., Fernández-Suárez, J., Quesada, C., Linnemann, U., D'Lemos, R., and Pisarevsky, S. 2008. Neoproterozoic-early Palaeozoic tectonostratigaphy and palaeogeography of the peri-Gondwanan terranes: Amazonian v. West African connections. In The boundaries of the West African craton. Edited by N. Ennih and J-P Liégeois. Geological Society of London, Special Publications 297, pp. 345-383.

Neuman, R. 1984. Geology and paleobiology of islands in the Ordovician Iapetus Ocean-Review and implications. Geological Society of America Bulletin, 95, pp. 11881201. https://doi.org/10.1130/0016-7606(1984)95<1188 :GAPOII $>2.0 . \mathrm{CO} ; 2$

Noda, A., TuZino, T., Joshima, M., and Goto, S. 2013. Mass-transport-dominated sedimentation in a foreland basin, the Hidaka Trough, northern Japan. Geochemistry, Geophysics, Geosystems, 14, pp. 2638-2660. https://doi. org/10.1002/ggge.20169

Orr, P. and Pickerill, R. 1995. Trace fossils from Early Silurian flysch of the Waterville Formation, Maine, USA. Northeastern Geology and Environmental Sciences, 17, pp. 394-414.

Osberg, P. 1968. Stratigraphy, structural geology, and metamorphism of the Waterville-Vassalboro area, Maine. Maine Geological Survey Bulletin 20, 64 pp., with map, scale 1:62 500 .

Osberg, P. 1988. Geologic relations within the shale-wacke sequence in south-central Maine. Maine Geological Survey, Studies in Maine Geology, 1, pp. 51-73.

Osberg, P., Hussey, A., II, and Boone, G. 1985. Bedrock Geologic Map of Maine. Maine Geological Survey, scale 1:500 000 .

Osberg, P., Tull, J., Robinson, P., Hon, R., and Butler, J. 1989. The Acadian orogen. In The Appalachian-Ouachita Orogen in the United States. Edited by R. Hatcher, W. Thomas, and G. Viele. Geological Society of America, The Geology of North America, F2, pp. 179-232.

Pankiwskyj, K., Ludman, A., Griffin, J., and Berry, W. 1976. 
Stratigraphic relationships on the southeast limb of the Merrimack Synclinorium in central and west-central Maine. In Studies in New England Geology. Edited by A. Brownlow and P. Lyons. Geological Society of America Memoir, 146, pp. 263-280.

Park, A. and Whitehead, J. 2003. Structural transect through Silurian turbidites of the Fredericton Belt southwest of Fredericton, New Brunswick: the role of the Fredericton Fault in late Iapetus convergence. Atlantic Geology, 39, p. 227-237. https://doi.org/10.4138/1183

Perkins, E. and Smith, E. 1925. Contributions to the geology of Maine, No. 1. A geological section from the Kennebec River to Penobscot Bay. American Journal of Science, 9, pp. 204-225. https://doi.org/10.2475/ajs.55-9.51.204

Pickerill, R. and Fyffe, L. 1999. The stratigraphic significance of trace fossils from the Lower Paleozoic Baskahegan Lake Formation near Woodstock, west-central New Brunswick. Atlantic Geology, 35, pp. 205-214. https:// doi.org/10.4138/2035

Pollock, S. 2012. Bedrock geology of the Belfast quadrangle, Maine. Maine Geological Survey, Open-File Map 12-37, scale 1:24 000 .

Rickards, R. and Riva, J. 1981. Glyptograptus? Persculptus (Salter), its tectonic deformation, and its stratigraphic significance for the Carys Mills Formation of N.E. Maine, U.S.A. Geological Journal, 16, pp. 219-235. https://doi. org/10.1002/gj.3350160402

Ruitenberg, A. and Ludman A. 1978. Stratigraphy and tectonic setting of Early Paleozoic rocks in the Wirral-Big Lake area, southwestern New Brunswick and southeastern Maine. Canadian Journal of Earth Sciences, 15, pp. 22-32.

Seaman, S. and Hamdi, S. 2018. Crustal structure and Late Paleozoic supervolcano-scale eruptions in Maine, USA. In 53nd Northeastern Annual Section Meeting, Burlington, Vermont, March 18-20, 2018. Geological Society of America Abstracts with Programs, 50, No. 2. https://doi. org/10.1130/abs/2018NE-311335

Sorota, K. 2013. Age and origin of the Merrimack terrane, southeastern New England: a detrital zircon $\mathrm{U}-\mathrm{Pb}$ geochronology study. Unpublished M.S. thesis, Boston College, Boston, Massachusetts, $153 \mathrm{pp}$.

Stacey, J.S. and Kramers, J.D. 1975. Approximation of terrestrial lead isotope evolution by a two-stage model. Earth and Planetary Science Letters, 26, pp. 207-221. https:// doi.org/10.1016/0012-821X(75)90088-6

Steiger, R.H. and Jäger, E. 1977. Subcommission on geochronology: Convention on the use of decay constants in geo- and cosmochronology. Earth and Planetary Science Letters 36(3), pp. 359-362. https://doi.org/10.1016/0012$\underline{821 X(77) 90060-7}$

Tremblay, A. and Pinet, N. 2005. Diachronous supracrustal extension in an intraplate setting and the origin of the Connecticut Valley-Gaspé and Merrimack troughs, northern Appalachians. Geological Magazine, 142, pp. 7-22. https://doi.org/10.1017/S001675680400038X

Tremblay, A. and Pinet, N. 2016. Late Neoproterozoic to
Permian tectonic evolution of the Quebec Appalachians, Canada. Earth-Science Reviews, 160, pp. 131-170. https://doi.org/10.1016/j.earscirev.2016.06.015

Tucker, R., Osberg, P., and Berry H. 2001. The geology of a part of Acadia and the nature of the Acadian orogeny across central and eastern Maine. American Journal of Science, 301, pp. 205-260. https://doi.org/10.2475/ ajs.301.3.205

van Staal, C., Barr, S., and Murphy, B. 2012. Provenance and tectonic evolution of Ganderia: Constraints on the evolution of the Iapetus and Rheic oceans. Geology, 40, pp. 987-990. https://doi.org/10.1130/G33302.1

van Staal, C., Currie, K., Rowbotham, G., Goodfellow, W., and Rogers, N. 2008. Pressure-temperature paths and exhumation of Late Ordovician-Early Silurian blueschists and associated metamorphic nappes of the Salinic Brunswick subduction complex, northern Appalachians. Geological Society of America Bulletin, 120, pp. 1455-1477. https://doi.org/10.1130/B26324.1

van Staal, C., Whalen, J., Valverde-Vaquero, P., Zagorevski, A., and Rogers, N. 2009. Pre- Carboniferous, episodic accretion-related, orogenesis along the Laurentian margin of the Northern Appalachians. In Ancient orogens and modern analogues. Edited by B. Murphy, D. Keppie, and A. Hynes. Geological Society of London, Special Publications, 327, pp. 271-316. https://doi.org/10.1144/SP327.13 van Staal, C., Wilson, R., Kamo, S., McClelland, W, and McNicoll, V. 2016. Evolution of the Early to Middle Ordovician Popelogan arc in New Brunswick, Canada, and adjacent Maine, USA: Record of arc-trench migration and multiple phases of rifting. Geological Society of America Bulletin, 128, pp. 122-146.

Walsh, G., Aleinikoff, J., and Wintsch, R. 2007. Origin of the Lyme Dome and implications for the timing of multiple Alleghanian deformational and intrusive events in southern Connecticut. American Journal of Science, 307, pp. 168-215. https://doi.org/10.2475/01.2007.06

West, D. 2006. Bedrock geology of the Washington quadrangle, Maine. Maine Geological Survey, Open-File Map 06-79, scale 1:24 000.

West, D., Ludman, A., and Lux, D. 1992. Silurian age for the Pocomoonshine gabbro-diorite, southeastern Maine, and its tectonic implications. American Journal of Science, 292, pp. 253-273. https://doi.org/10.2475/ajs.292.4.253

Williams, H. 1979. Appalachian orogen in Canada. Canadian Journal of Earth Sciences, 1979, 16, 792-807. https:// doi.org/10.1139/e79-070

Williams, I. 1998. Chapter 1, U-Th-Pb geochronology by ion microprobe. In Applications of microanalytical techniques to understanding mineralizing processes. Edited by M. McKibben, W. Shanks, III, and W. Ridley. Reviews in Economic Geology, 7, pp. 1-35.

Wilson, R., van Staal, C., and McClelland, W. 2015. Synaccretionary sedimentary and volcanic rocks in the Ordovician Tetagouche backarc basin, New Brunswick, Canada: evidence for a transition from foredeep to forearc basin sedimentation. American Journal of Science, 315, 
pp. 958-1001. https://doi.org/10.2475/10.2015.03

Wintsch, R., Aleinikoff, J., Walsh, G., Bothner, W., Hussey, A.M., II, and Fanning, C. 2007. SHRIMP U-Pb evidence for a Late Silurian age of metasedimentary rocks in the Merrimack and Putnam-Nashoba terranes, eastern New England; American Journal of Science, 307, pp. 119-167. https://doi.org/10.2475/01.2007.05

Wones, D. and Ayuso, R. 1993. Geologic map of the Lucerne
Granite, Hancock and Penobscot Counties, Maine. United States Geological Survey Miscellaneous Investigations Series Map I-2360, Scale 1:250 000.

Yu, H. and Chou, Y. 2001. Characteristics and development of the flexural forebulge and basal unconformity of western Taiwan foreland basin. Tectonophysics, 333, 277-291. https://doi.org/10.1016/S0040-1951(00)00279-1

Editorial responsibility: Sandra M. Barr 
Appendix A. Comparison of current chronostratigraphic nomenclature (after Cohen et al. 2013, 2017 modification) with British series names used in reports of fossil control of stratigraphic units in Maine in 1950s through 1970s.

\begin{tabular}{|c|c|c|c|}
\hline Period & $\begin{array}{l}\text { Global } \\
\text { Series }\end{array}$ & $\begin{array}{l}\text { Global } \\
\text { Stage }\end{array}$ & $\begin{array}{c}\text { U.K. } \\
\text { Series }\end{array}$ \\
\hline Devonian & $\begin{array}{c}\text { Lower } \\
\text { Devonian }\end{array}$ & $\begin{array}{c}\text { Pragian } \\
410.8 \pm 2.8 \\
\text { Lockhovian }\end{array}$ & \\
\hline \multirow{4}{*}{ Silurian } & $\begin{array}{r}\text { Pridoli } \\
4230+23\end{array}$ & & \\
\hline & Ludlow & \begin{tabular}{|c} 
Ludfordian \\
425.6 \pm 0.9 \\
Gorstian \\
\end{tabular} & \\
\hline & Wenlock & $\begin{array}{c}\text { Homerian } \\
\text { S30.5 } \pm 0.7 \\
\text { Sheinwoodian }\end{array}$ & \\
\hline & Llandovery & $\begin{array}{c}\text { Telychian } \\
\text { 438.5 } \pm 1.1 \\
\text { Aeronian } \\
\text { 440.8 } \pm 1.2 \\
\text { Rhuddanian }\end{array}$ & \\
\hline \multirow{6}{*}{ Ordovician } & \multirow[t]{2}{*}{ Upper } & $\begin{array}{c}\text { Hirnantian } \\
\text { Katian }\end{array}$ & Ashgill \\
\hline & & $\begin{array}{l}453.0 \pm 0.9 \\
\text { Sandbian }\end{array}$ & Caradoc \\
\hline & \multirow{2}{*}{ Middle } & Darriwilian & $\begin{array}{l}\text { Llandeilo } \\
\text { Llanvirn }\end{array}$ \\
\hline & & $\begin{array}{l}\text { 467.3 } \pm 1.1 \\
\text { Dapingian }\end{array}$ & Arenig \\
\hline & \multirow[t]{2}{*}{ Lower } & $\begin{array}{c}\text { Floian } \\
477.7 \pm 1.4\end{array}$ & \\
\hline & & Tremadocian & Tremadoc \\
\hline Cambria & Furongian & & \\
\hline
\end{tabular}




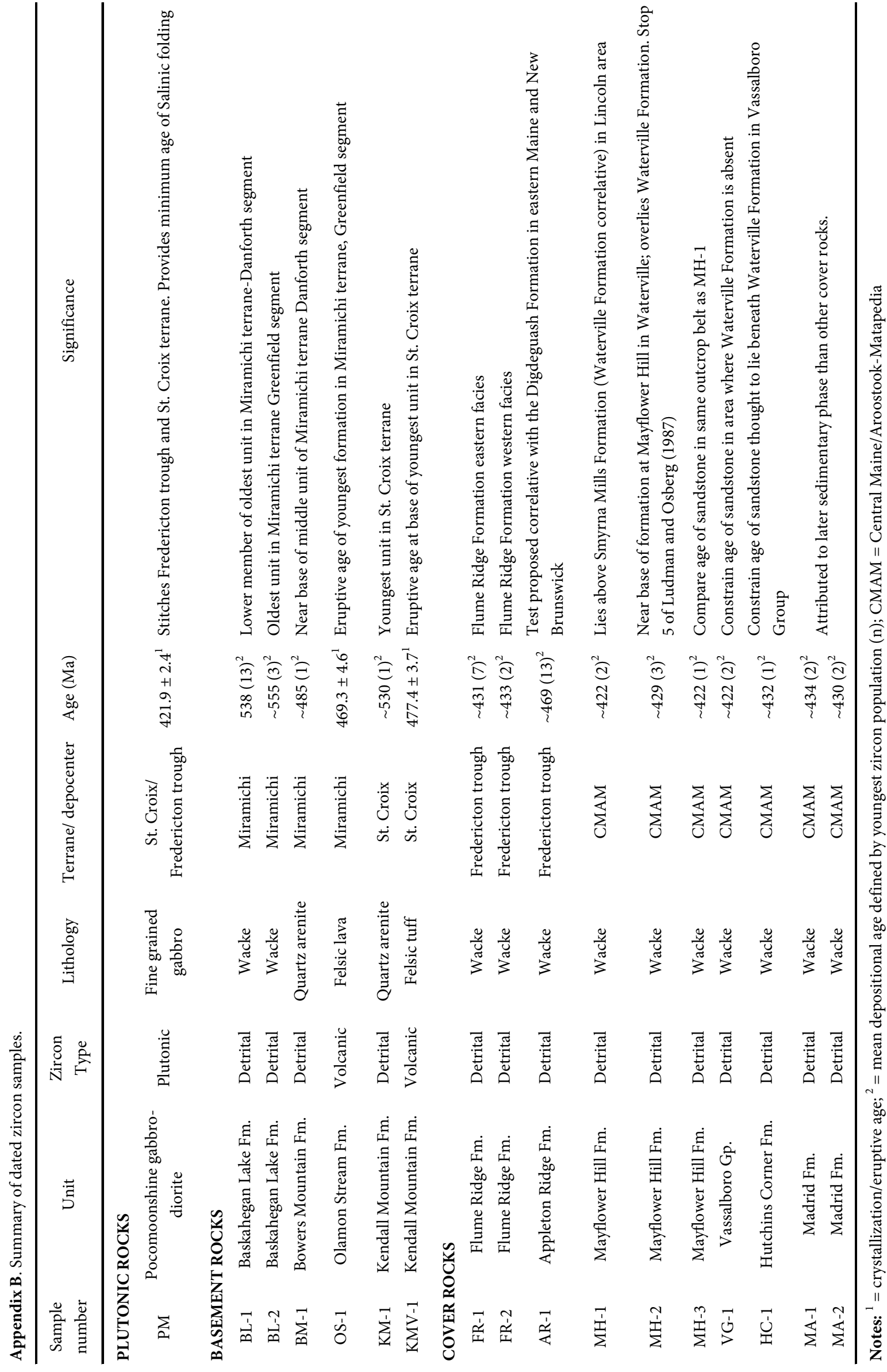


Appendix C. SHRIMP U-Th-Pb data for detrital zircons from sedimentary rocks of eastern and east-central Maine. Asterisks indicate grains with greater than $10 \%$ discordance; these are not included in relative probability plots. Location coordinates in UTM metres, (Zone 19, NAD27).

\begin{tabular}{|c|c|c|c|c|c|c|c|c|c|c|c|c|c|c|}
\hline \multirow[b]{2}{*}{ sample $^{1}$} & \multirow[b]{2}{*}{$\begin{array}{l}\text { measured } \\
{ }^{204} \mathrm{~Pb} /{ }^{206} \mathrm{~Pb}\end{array}$} & \multirow[b]{2}{*}{$\begin{array}{l}\text { measured } \\
{ }^{207} \mathrm{~Pb} /{ }^{206} \mathrm{~Pb}\end{array}$} & \multirow[b]{2}{*}{$\begin{array}{l}\text { \%common } \\
{ }^{206} \mathrm{~Pb}\end{array}$} & \multirow[b]{2}{*}{$\begin{array}{c}\mathrm{U} \\
(\mathrm{ppm})\end{array}$} & \multirow[b]{2}{*}{$\mathrm{Th} / \mathrm{U}$} & \multicolumn{4}{|c|}{ Age (Ma) } & \multirow[b]{2}{*}{${ }^{207} \mathrm{~Pb} /$} & \multirow[b]{2}{*}{$\begin{array}{l}\operatorname{err}^{4} \\
(\%)\end{array}$} & \multirow[b]{2}{*}{${ }^{206} \mathrm{~Pb} /$} & \multirow[b]{2}{*}{$\begin{array}{l}\operatorname{err}^{4} \\
(\%)\end{array}$} & \multirow[b]{2}{*}{$\begin{array}{l}\text { err. } \\
\text { corr. }\end{array}$} \\
\hline & & & & & & $\begin{array}{l}{ }^{206} \mathrm{~Pb} / \\
{ }^{238} \mathrm{U}^{2}\end{array}$ & $\operatorname{err}^{4}$ & $\begin{array}{l}{ }^{207} \mathrm{~Pb} / \\
{ }^{206} \mathrm{~Pb}^{2,3}\end{array}$ & $\mathrm{err}^{4}$ & & & & & \\
\hline \multicolumn{15}{|c|}{ PRE-SILURIAN ROCKS } \\
\hline \multicolumn{15}{|c|}{ MIRAMICHI TERRANE } \\
\hline & \multicolumn{14}{|c|}{$\begin{array}{l}\text { Baskahegan Lake Formation (BL } \\
\text { Location } 0597548 \mathrm{E} / 5039799 \mathrm{~N}\end{array}$} \\
\hline 12A64-1.1 & --- & 0.0597 & 0 & 64 & 0.47 & 668 & 9 & & & 0.9 & 3.3 & 0.109 & 1.5 & 0.4 \\
\hline $12 \mathrm{~A} 64-2.1$ & 0.000068 & 0.0599 & 0.121 & 408 & 0.59 & 544 & 4 & & & 0.7 & 1.7 & 0.088 & 0.8 & 0.5 \\
\hline $12 \mathrm{~A} 64-3.1$ & 0.000026 & 0.0577 & 0.047 & 198 & 0.75 & 542 & 5 & & & 0.7 & 2.1 & 0.088 & 1.0 & 0.4 \\
\hline $12 \mathrm{~A} 64-4.1$ & 0.000060 & 0.0984 & 0.096 & 85 & 0.63 & 1576 & 17 & 1578 & 25 & 3.7 & 1.8 & 0.277 & 1.2 & 0.7 \\
\hline $12 \mathrm{~A} 64-5.1$ & 0.000152 & 0.0999 & 0.244 & 255 & 0.46 & 1490 & 12 & 1582 & 16 & 3.5 & 1.3 & 0.260 & 0.9 & 0.7 \\
\hline $12 \mathrm{~A} 64-6.1$ & 0.000012 & 0.1295 & 0.019 & 104 & 0.75 & 1995 & 20 & 2089 & 15 & 6.5 & 1.4 & 0.363 & 1.1 & 0.8 \\
\hline $12 \mathrm{~A} 64-7.1$ & 0.000112 & 0.0587 & 0.201 & 128 & 0.94 & 571 & 6 & & & 0.7 & 2.9 & 0.093 & 1.1 & 0.4 \\
\hline $12 \mathrm{~A} 64-8.1$ & 0.000102 & 0.1171 & 0.157 & 235 & 0.88 & 1839 & 15 & 1891 & 13 & 5.3 & 1.2 & 0.330 & 0.9 & 0.8 \\
\hline $12 \mathrm{~A} 64-9.1$ & --- & 0.0964 & 0 & 43 & 0.60 & 1544 & 22 & 1554 & 33 & 3.6 & 2.4 & 0.271 & 1.6 & 0.7 \\
\hline 12A64-10.1 & 0.000031 & 0.1121 & 0.048 & 97 & 0.62 & 1809 & 19 & 1826 & 19 & 5 & 1.6 & 0.324 & 1.2 & 0.7 \\
\hline 12A64-11.1 & 0.000009 & 0.0801 & 0.015 & 260 & 0.34 & 1206 & 10 & 1194 & 22 & 2.3 & 1.4 & 0.206 & 0.9 & 0.6 \\
\hline $12 \mathrm{~A} 64-12.1$ & 0.000123 & 0.0577 & 0.222 & 178 & 0.64 & 535 & 5 & & & 0.7 & 2.8 & 0.087 & 1.0 & 0.4 \\
\hline 12A64-13.1 & -0.000038 & 0.0615 & -0.066 & 134 & 0.51 & 586 & 6 & & & 0.8 & 2.5 & 0.095 & 1.1 & 0.4 \\
\hline $12 \mathrm{~A} 64-14.1$ & 0.000016 & 0.0592 & 0.029 & 348 & 1.12 & 545 & 5 & & & 0.7 & 1.7 & 0.088 & 0.9 & 0.5 \\
\hline $12 \mathrm{~A} 64-15.1$ & --- & 0.0897 & 0 & 117 & 0.37 & 1376 & 14 & 1419 & 23 & 2.9 & 1.6 & 0.238 & 1.1 & 0.7 \\
\hline $12 \mathrm{~A} 64-16.1$ & 0.001743 & 0.0932 & 3.013 & 368 & 0.59 & 746 & 11 & & & 1.2 & 13.7 & 0.123 & 1.6 & 0.1 \\
\hline $12 \mathrm{~A} 64-17.1$ & 0.000159 & 0.0900 & 0.260 & 105 & 0.42 & 1338 & 14 & 1376 & 30 & 2.8 & 2.0 & 0.231 & 1.2 & 0.6 \\
\hline 12A64-18.1 & 0.000057 & 0.0612 & 0.102 & 410 & 0.21 & 641 & 5 & & & 0.9 & 1.6 & 0.105 & 0.8 & 0.5 \\
\hline 12A64-19.1 & 0.000040 & 0.0615 & 0.072 & 377 & 1.37 & 610 & 5 & & & 0.8 & 1.6 & 0.099 & 0.9 & 0.5 \\
\hline $12 \mathrm{~A} 64-20.1$ & 0.000091 & 0.0818 & 0.152 & 79 & 0.59 & 1207 & 14 & 1210 & 37 & 2.3 & 2.3 & 0.206 & 1.3 & 0.6 \\
\hline $12 \mathrm{~A} 64-21.1$ & -0.000034 & 0.0585 & -0.061 & 156 & 0.59 & 568 & 6 & & & 0.8 & 2.4 & 0.092 & 1.0 & 0.4 \\
\hline $12 \mathrm{~A} 64-22.1$ & 0.000009 & 0.1373 & 0.013 & 298 & 0.41 & 2193 & 17 & 2191 & 9 & 7.7 & 1.0 & 0.405 & 0.9 & 0.9 \\
\hline $12 \mathrm{~A} 64-23.1$ & -0.000025 & 0.1082 & -0.039 & 65 & 0.58 & 1788 & 22 & 1774 & 29 & 4.8 & 2.1 & 0.320 & 1.4 & 0.7 \\
\hline $12 \mathrm{~A} 64-24.1$ & 0.000081 & 0.0866 & 0.133 & 50 & 0.55 & 1387 & 19 & 1325 & 40 & 2.8 & 2.6 & 0.240 & 1.5 & 0.6 \\
\hline $12 \mathrm{~A} 64-25.1$ & 0.000016 & 0.0805 & 0.026 & 160 & 0.73 & 1197 & 11 & 1203 & 24 & 2.3 & 1.6 & 0.204 & 1.0 & 0.6 \\
\hline $12 \mathrm{~A} 64-26.1$ & 0.000038 & 0.0579 & 0.069 & 282 & 0.16 & 542 & 5 & & & 0.7 & 1.9 & 0.088 & 0.9 & 0.5 \\
\hline $12 \mathrm{~A} 64-27.1$ & -0.000046 & 0.0743 & -0.078 & 66 & 0.49 & 1026 & 13 & 1066 & 45 & 1.8 & 2.6 & 0.173 & 1.4 & 0.5 \\
\hline $12 \mathrm{~A} 64-28.1$ & --- & 0.0741 & 0 & 366 & 0.41 & 1039 & 8 & 1044 & 18 & 1.8 & 1.2 & 0.175 & 0.9 & 0.7 \\
\hline $12 \mathrm{~A} 64-29.1$ & 0.000018 & 0.0590 & 0.031 & 303 & 2.75 & 593 & 5 & & & 0.8 & 1.8 & 0.096 & 1.0 & 0.5 \\
\hline $12 \mathrm{~A} 64-30.1$ & -0.000031 & 0.0592 & -0.055 & 362 & 0.90 & 531 & 4 & & & 0.7 & 1.7 & 0.086 & 0.9 & 0.5 \\
\hline 12A64-31.1 & 0.000052 & 0.0591 & 0.094 & 111 & 1.21 & 561 & 11 & & & 0.7 & 3.5 & 0.091 & 2.0 & 0.6 \\
\hline $12 \mathrm{~A} 64-32.1$ & 0.000023 & 0.0841 & 0.038 & 302 & 0.62 & 1287 & 15 & 1286 & 16 & 2.6 & 1.5 & 0.221 & 1.3 & 0.8 \\
\hline $12 \mathrm{~A} 64-33.1$ & --- & 0.0587 & 0 & 133 & 0.90 & 524 & 6 & & & 0.7 & 2.5 & 0.085 & 1.1 & 0.4 \\
\hline $12 \mathrm{~A} 64-34.1$ & --- & 0.0618 & 0 & 245 & 0.35 & 643 & 6 & & & 0.9 & 1.8 & 0.105 & 0.9 & 0.5 \\
\hline $12 \mathrm{~A} 64-35.1$ & -0.000046 & 0.1584 & -0.066 & 24 & 0.30 & 2376 & 41 & 2445 & 26 & 9.8 & 2.6 & 0.446 & 2.1 & 0.8 \\
\hline $12 \mathrm{~A} 64-36.1$ & 0.000049 & 0.0648 & 0.085 & 182 & 0.74 & 682 & 6 & & & 1 & 2.1 & 0.112 & 1.0 & 0.5 \\
\hline $12 \mathrm{~A} 64-37.1$ & --- & 0.0804 & 0 & 308 & 0.38 & 1220 & 10 & 1206 & 16 & 2.3 & 1.2 & 0.208 & 0.9 & 0.7 \\
\hline $12 \mathrm{~A} 64-38.1$ & 0.000056 & 0.0620 & 0.099 & 250 & 0.92 & 651 & 6 & & & 0.9 & 1.9 & 0.106 & 0.9 & 0.5 \\
\hline $12 \mathrm{~A} 64-39.1$ & 0.000058 & 0.0824 & 0.097 & 119 & 0.87 & 1269 & 13 & 1235 & 28 & 2.4 & 1.8 & 0.218 & 1.1 & 0.6 \\
\hline $12 \mathrm{~A} 64-40.1$ & 0.000014 & 0.0578 & 0.026 & 418 & 1.54 & 533 & 4 & & & 0.7 & 1.6 & 0.086 & 0.9 & 0.5 \\
\hline $12 \mathrm{~A} 64-41.1$ & 0.000010 & 0.0965 & 0.016 & 178 & 0.70 & 1560 & 14 & 1554 & 17 & 3.6 & 1.3 & 0.274 & 1.0 & 0.7 \\
\hline $12 \mathrm{~A} 64-42.1$ & 0.000111 & 0.0806 & 0.186 & 45 & 1.08 & 1214 & 18 & 1171 & 53 & 2.3 & 3.1 & 0.207 & 1.6 & 0.5 \\
\hline $12 \mathrm{~A} 64-43.1$ & --- & 0.0744 & 0 & 95 & 0.44 & 977 & 20 & 1052 & 36 & 1.7 & 2.8 & 0.164 & 2.2 & 0.8 \\
\hline $12 \mathrm{~A} 64-44.1$ & --- & 0.0575 & 0 & 352 & 0.12 & 526 & 4 & & & 0.7 & 1.9 & 0.085 & 0.9 & 0.5 \\
\hline
\end{tabular}


Appendix C: Continued.

\begin{tabular}{|c|c|c|c|c|c|c|c|c|c|c|c|c|c|c|}
\hline \multirow[b]{2}{*}{ sample $^{1}$} & \multirow[b]{2}{*}{$\begin{array}{l}\text { measured } \\
{ }^{204} \mathrm{~Pb} /{ }^{206} \mathrm{~Pb}\end{array}$} & \multirow[b]{2}{*}{$\begin{array}{l}\text { measured } \\
{ }^{207} \mathrm{~Pb} /{ }^{206} \mathrm{~Pb}\end{array}$} & \multirow[b]{2}{*}{$\begin{array}{l}\text { \%common } \\
{ }^{206} \mathrm{~Pb}\end{array}$} & \multirow[b]{2}{*}{$\begin{array}{c}\mathrm{U} \\
(\mathrm{ppm})\end{array}$} & \multirow[b]{2}{*}{$\mathrm{Th} / \mathrm{U}$} & \multicolumn{4}{|c|}{ Age (Ma) } & \multirow[b]{2}{*}{$\begin{array}{l}{ }^{207} \mathrm{~Pb} / \\
{ }^{235} \mathrm{U}^{5}\end{array}$} & \multirow[b]{2}{*}{$\begin{array}{l}\operatorname{err}^{4} \\
(\%)\end{array}$} & \multirow[b]{2}{*}{$\begin{array}{l}{ }^{206} \mathrm{~Pb} / \\
{ }^{238} \mathrm{U}^{5}\end{array}$} & \multirow[b]{2}{*}{$\begin{array}{l}\operatorname{err}^{4} \\
(\%)\end{array}$} & \multirow[b]{2}{*}{$\begin{array}{l}\text { err. } \\
\text { corr. }\end{array}$} \\
\hline & & & & & & $\begin{array}{l}{ }^{206} \mathrm{~Pb} / \\
{ }^{238} \mathrm{U}^{2}\end{array}$ & $\mathrm{err}^{4}$ & $\begin{array}{l}{ }^{207} \mathrm{~Pb} / \\
{ }^{206} \mathrm{~Pb}^{2,3}\end{array}$ & $\operatorname{err}^{4}$ & & & & & \\
\hline $12 \mathrm{~A} 64-45.1$ & 0.000015 & 0.1135 & 0.023 & 204 & 0.86 & 1865 & 16 & 1852 & 13 & 5.2 & 1.2 & 0.336 & 1.0 & 0.8 \\
\hline $12 \mathrm{~A} 64-46.1$ & 0.000080 & 0.1152 & 0.123 & 74 & 0.75 & 1836 & 21 & 1865 & 22 & 5.2 & 1.8 & 0.330 & 1.3 & 0.7 \\
\hline $12 \mathrm{~A} 64-47.1$ & --- & 0.0820 & 0 & 161 & 0.51 & 1199 & 11 & 1245 & 23 & 2.3 & 1.5 & 0.205 & 1.0 & 0.7 \\
\hline $12 \mathrm{~A} 64-48.1$ & -0.000332 & 0.0584 & -0.583 & 70 & 0.99 & 555 & 7 & & & 0.8 & 5.0 & 0.090 & 1.4 & 0.3 \\
\hline $12 \mathrm{~A} 64-50.1$ & 0.000039 & 0.0623 & 0.069 & 233 & 1.02 & 653 & 6 & & & 0.9 & 1.9 & 0.107 & 0.9 & 0.5 \\
\hline 12A64-51.1 & 0.000099 & 0.0706 & 0.171 & 61 & 0.44 & 958 & 13 & & & 1.5 & 3.1 & 0.160 & 1.4 & 0.5 \\
\hline $12 \mathrm{~A} 64-52.1$ & 0.000036 & 0.0708 & 0.062 & 82 & 0.34 & 1039 & 12 & & & 1.7 & 2.7 & 0.175 & 1.3 & 0.5 \\
\hline $12 \mathrm{~A} 64-53.1$ & -0.000017 & 0.1173 & -0.026 & 174 & 0.50 & 1892 & 17 & 1918 & 13 & 5.5 & 1.3 & 0.341 & 1.0 & 0.8 \\
\hline $12 \mathrm{~A} 64-54.1$ & -0.000102 & 0.0530 & -0.184 & 189 & 2.38 & 552 & 6 & & & 0.7 & 3.2 & 0.089 & 1.1 & 0.4 \\
\hline 12A64-55.1 & -0.000003 & 0.1836 & -0.004 & 309 & 0.64 & 2568 & 19 & 2686 & 6 & 12.4 & 1.0 & 0.489 & 0.9 & 0.9 \\
\hline 12A64-56.1 & 0.000043 & 0.0618 & 0.075 & 156 & 1.44 & 534 & 6 & & & 0.7 & 2.7 & 0.086 & 1.2 & 0.4 \\
\hline 12A64-57.1 & 0.000067 & 0.0616 & 0.118 & 217 & 1.23 & 615 & 6 & & & 0.8 & 2.1 & 0.100 & 1.0 & 0.5 \\
\hline 12A64-58.1 & 0.000031 & 0.0589 & 0.056 & 179 & 0.78 & 539 & 5 & & & 0.7 & 2.3 & 0.087 & 1.0 & 0.4 \\
\hline $12 \mathrm{~A} 64-59.1$ & 0.000088 & 0.0626 & 0.155 & 79 & 1.16 & 511 & 7 & & & 0.7 & 4.1 & 0.082 & 1.4 & 0.3 \\
\hline $12 \mathrm{~A} 64-60.1$ & -0.000248 & 0.0574 & -0.439 & 48 & 0.28 & 602 & 10 & & & 0.8 & 5.8 & 0.098 & 1.8 & 0.3 \\
\hline 12A64-61.1 & --- & 0.0602 & 0 & 249 & 0.58 & 533 & 5 & & & 0.7 & 2.0 & 0.086 & 1.0 & 0.5 \\
\hline $12 \mathrm{~A} 64-62.1$ & 0.000033 & 0.0731 & 0.056 & 447 & 0.23 & 1015 & 13 & 1004 & 19 & 1.7 & 1.7 & 0.171 & 1.4 & 0.8 \\
\hline 12A64-63.1 & 0.000062 & 0.0621 & 0.109 & 191 & 0.61 & 678 & 7 & & & 0.9 & 2.4 & 0.111 & 1.1 & 0.4 \\
\hline 12A64-64.1 & 0.000260 & 0.0596 & 0.469 & 142 & 1.24 & 582 & 6 & & & 0.7 & 3.9 & 0.094 & 1.2 & 0.3 \\
\hline $12 \mathrm{~A} 64-65.1$ & -0.000164 & 0.0600 & -0.290 & 44 & 1.23 & 539 & 9 & & & 0.8 & 5.9 & 0.087 & 1.8 & 0.3 \\
\hline $12 \mathrm{~A} 64-66.1$ & --- & 0.0635 & 0 & 313 & 0.39 & 634 & 6 & & & 0.9 & 2.0 & 0.103 & 0.9 & 0.5 \\
\hline 12A64-67.1 & 0.000025 & 0.0602 & 0.044 & 258 & 0.36 & 631 & 6 & & & 0.8 & 2.0 & 0.103 & 1.0 & 0.5 \\
\hline 12A64-68.1 & --- & 0.0622 & 0 & 231 & 1.32 & 632 & 6 & & & 0.9 & 2.0 & 0.103 & 1.0 & 0.5 \\
\hline 12A64-69.1 & 0.000050 & 0.0822 & 0.084 & 182 & 0.50 & 1183 & 24 & 1232 & 46 & 2.3 & 3.2 & 0.201 & 2.2 & 0.7 \\
\hline $12 \mathrm{~A} 64-70.1$ & 0.000075 & 0.1041 & 0.118 & 115 & 0.60 & 1651 & 29 & 1680 & 23 & 4.2 & 2.3 & 0.292 & 2.0 & 0.8 \\
\hline
\end{tabular}

Baskahegan Lake Formation (BL) : BL-2 Miramichi Greenfield segment. Greenfield quadrangle, UTM Location 0540624E/4986141N

\begin{tabular}{|c|c|c|c|c|c|c|c|c|c|c|c|c|c|c|}
\hline 14B47-1.1 & 0.000458 & 0.0746 & 0.792 & 65 & 0.98 & 1044 & 19 & & & 1.65 & 5.9 & 0.176 & 2.0 & 0.3 \\
\hline $14 \mathrm{~B} 47-2.1$ & -0.000004 & 0.0948 & -0.007 & 268 & 0.30 & 1488 & 20 & 1525 & 10 & 3.40 & 1.6 & 0.260 & 1.5 & 0.9 \\
\hline 14B47-3.1 & 0.000043 & 0.0608 & 0.075 & 282 & 0.52 & 610 & 9 & & & 0.82 & 2.1 & 0.099 & 1.5 & 0.7 \\
\hline $14 \mathrm{~B} 47-4.1$ & 0.000088 & 0.1459 & 0.128 & 70 & 0.71 & 2333 & 31 & 2284 & 15 & 8.70 & 1.8 & 0.436 & 1.6 & 0.9 \\
\hline 14B47-5.1 & 0.000043 & 0.0773 & 0.072 & 448 & 0 & 1134 & 15 & 1113 & 14 & 2.04 & 1.6 & 0.192 & 1.5 & 0.9 \\
\hline 14B47-6.1 & -0.000053 & 0.0589 & -0.093 & 130 & 0.53 & 558 & 11 & & & 0.74 & 3.2 & 0.090 & 2.0 & 0.6 \\
\hline 14B47-7.1 & 0.000032 & 0.0985 & 0.052 & 480 & 0.42 & 1558 & 24 & 1586 & 8 & 3.69 & 1.8 & 0.273 & 1.7 & 1.0 \\
\hline 14B47-8.1 & -0.000031 & 0.0618 & -0.054 & 89 & 0.51 & 696 & 10 & & & 0.98 & 2.9 & 0.114 & 1.6 & 0.5 \\
\hline 14B $47-10.1$ & 0.000053 & 0.0813 & 0.088 & 169 & 0.38 & 1214 & 19 & 1210 & 22 & 2.30 & 2.1 & 0.207 & 1.7 & 0.8 \\
\hline 14B47-11.1 & 0.000253 & 0.0629 & 0.451 & 104 & 1.15 & 637 & 10 & & & 0.85 & 6.2 & 0.104 & 1.6 & 0.3 \\
\hline 14B $47-12.1$ & 0.000006 & 0.1391 & 0.008 & 410 & 0.51 & 2183 & 29 & 2214 & 9 & 7.72 & 1.6 & 0.403 & 1.6 & 1.0 \\
\hline 14B47-13.1 & -0.000055 & 0.0671 & -0.096 & 162 & 0.60 & 799 & 11 & & & 1.24 & 2.3 & 0.132 & 1.5 & 0.7 \\
\hline 14B47-14.1 & 0.000422 & 0.0732 & 0.732 & 43 & 0.53 & 975 & 16 & & & 1.51 & 6.9 & 0.163 & 1.7 & 0.3 \\
\hline 14B47-15.1 & 0.000087 & 0.0873 & 0.143 & 66 & 0.44 & 1200 & 58 & 1339 & 38 & 2.43 & 5.6 & 0.205 & 5.3 & 0.9 \\
\hline 14B47-16.1 & 0.000011 & 0.0828 & 0.018 & 131 & 0.40 & 1230 & 17 & 1261 & 18 & 2.40 & 1.8 & 0.210 & 1.5 & 0.9 \\
\hline 14B47-17.1 & -0.000005 & 0.1801 & -0.007 & 251 & 0.66 & 2685 & 51 & 2654 & 6 & 12.83 & 2.4 & 0.517 & 2.3 & 1.0 \\
\hline 14B47-18.1 & --- & 0.0801 & 0 & 141 & 0.27 & 1173 & 16 & 1198 & 17 & 2.20 & 1.7 & 0.200 & 1.5 & 0.9 \\
\hline 14B47-19.1 & 0.000204 & 0.1168 & 0.315 & 55 & 0.80 & 1857 & 26 & 1863 & 32 & 5.25 & 2.4 & 0.334 & 1.6 & 0.7 \\
\hline 14B47-20.1 & -0.000015 & 0.0610 & -0.026 & 392 & 0.65 & 625 & 9 & & & 0.86 & 1.8 & 0.102 & 1.5 & 0.8 \\
\hline 14B47-21.1 & -0.000007 & 0.0587 & -0.013 & 452 & 0.93 & 551 & 10 & & & 0.72 & 2.2 & 0.089 & 2.0 & 0.9 \\
\hline 14B47-22.1 & 0.000600 & 0.0640 & 1.082 & 53 & 0.54 & 675 & 12 & & & 0.84 & 12.9 & 0.110 & 1.8 & 0.1 \\
\hline $14 \mathrm{~B} 47-23.1$ & 0.000018 & 0.0623 & 0.031 & 339 & 0.40 & 613 & 9 & & & 0.85 & 2.6 & 0.100 & 1.5 & 0.6 \\
\hline
\end{tabular}


Appendix C: Continued.

\begin{tabular}{|c|c|c|c|c|c|c|c|c|c|c|c|c|c|c|}
\hline \multirow[b]{2}{*}{ sample $^{1}$} & \multirow[b]{2}{*}{$\begin{array}{l}\text { measured } \\
{ }^{204} \mathrm{~Pb} /{ }^{206} \mathrm{~Pb}\end{array}$} & \multirow[b]{2}{*}{$\begin{array}{l}\text { measured } \\
{ }^{207} \mathrm{~Pb} /{ }^{206} \mathrm{~Pb}\end{array}$} & \multirow[b]{2}{*}{$\begin{array}{l}\text { \%common } \\
{ }^{206} \mathrm{~Pb}\end{array}$} & \multirow[b]{2}{*}{$\begin{array}{c}\mathrm{U} \\
(\mathrm{ppm})\end{array}$} & \multirow[b]{2}{*}{$\mathrm{Th} / \mathrm{U}$} & \multicolumn{4}{|c|}{ Age (Ma) } & \multirow[b]{2}{*}{$\begin{array}{l}{ }^{207} \mathrm{~Pb} / \\
{ }^{235} \mathrm{U}^{5}\end{array}$} & \multirow[b]{2}{*}{$\begin{array}{l}\mathrm{err}^{4} \\
(\%)\end{array}$} & \multirow[b]{2}{*}{$\begin{array}{l}{ }^{206} \mathrm{~Pb} / \\
{ }^{238} \mathrm{U}^{5}\end{array}$} & \multirow[b]{2}{*}{$\begin{array}{l}\operatorname{err}^{4} \\
(\%)\end{array}$} & \multirow[b]{2}{*}{$\begin{array}{l}\text { err. } \\
\text { corr. }\end{array}$} \\
\hline & & & & & & $\begin{array}{l}{ }^{206} \mathrm{~Pb} / \\
{ }^{238} \mathrm{U}^{2}\end{array}$ & $\mathrm{err}^{4}$ & $\begin{array}{l}{ }^{207} \mathrm{~Pb} / \\
{ }^{206} \mathrm{~Pb}^{2,3}\end{array}$ & $\mathrm{err}^{4}$ & & & & & \\
\hline 14B47-24.1 & -0.000071 & 0.0630 & -0.125 & 79 & 0.59 & 671 & 14 & & & 0.97 & 3.8 & 0.110 & 2.3 & 0.6 \\
\hline 14B47-25.1 & -0.000030 & 0.0773 & -0.050 & 57 & 0.51 & 1058 & 17 & 1140 & 37 & 1.91 & 2.5 & 0.178 & 1.7 & 0.7 \\
\hline $14 \mathrm{~B} 47-26.1^{\star}$ & 0.000022 & 0.1640 & 0.032 & 108 & 0.91 & 2014 & 38 & 2494 & 10 & 8.28 & 2.3 & 0.367 & 2.2 & 1.0 \\
\hline 14B47-27.1 & 0.000016 & 0.0658 & 0.028 & 271 & 0.64 & 808 & 12 & & & 1.21 & 1.9 & 0.134 & 1.6 & 0.9 \\
\hline 14B47-28.1 & -0.000014 & 0.0832 & -0.023 & 105 & 0.66 & 1204 & 17 & 1278 & 21 & 2.36 & 1.9 & 0.205 & 1.5 & 0.8 \\
\hline 14B47-29.1 & 0.000098 & 0.0684 & 0.171 & 70 & 1.01 & 798 & 12 & & & 1.22 & 3.6 & 0.132 & 1.6 & 0.5 \\
\hline 14B47-30.1 & 0.000013 & 0.0972 & 0.022 & 241 & 0.35 & 1567 & 23 & 1567 & 30 & 3.68 & 2.3 & 0.275 & 1.7 & 0.7 \\
\hline 14B47-31.1 & 0.000410 & 0.0693 & 0.719 & 80 & 0.57 & 827 & 13 & & & 1.20 & 5.9 & 0.137 & 1.6 & 0.3 \\
\hline 14B47-32.1 & 0.000097 & 0.0882 & 0.160 & 41 & 0.59 & 1315 & 20 & 1356 & 48 & 2.71 & 3.0 & 0.226 & 1.7 & 0.6 \\
\hline 14B47-33.1 & 0.000046 & 0.0788 & 0.078 & 107 & 0.17 & 1071 & 15 & 1149 & 30 & 1.95 & 2.2 & 0.181 & 1.6 & 0.7 \\
\hline 14B47-34.1 & -0.000006 & 0.0809 & -0.010 & 246 & 0.53 & 1266 & 17 & 1220 & 13 & 2.42 & 1.6 & 0.217 & 1.5 & 0.9 \\
\hline 14B47-35.1 & 0.000025 & 0.0804 & 0.042 & 231 & 0.59 & 1244 & 17 & 1198 & 16 & 2.35 & 1.7 & 0.213 & 1.5 & 0.9 \\
\hline 14B47-36.1 & --- & 0.1243 & 0 & 253 & 0.42 & 1965 & 25 & 2018 & 7 & 6.11 & 1.5 & 0.356 & 1.5 & 1.0 \\
\hline 14B47-37.1 & 0.000019 & 0.2009 & 0.025 & 210 & 0.14 & 2697 & 33 & 2831 & 6 & 14.38 & 1.6 & 0.520 & 1.5 & 1.0 \\
\hline 14B47-38.1 & 0.000063 & 0.0755 & 0.107 & 1447 & 0.13 & 987 & 13 & 1057 & 9 & 1.70 & 1.5 & 0.165 & 1.5 & 1.0 \\
\hline 14B47-39.1 & 0.000067 & 0.0609 & 0.119 & 447 & 0.27 & 640 & 12 & & & 0.86 & 2.4 & 0.104 & 2.0 & 0.8 \\
\hline $14 \mathrm{~B} 47-40.1^{*}$ & 0.000270 & 0.1309 & 0.406 & 523 & 1.17 & 1788 & 23 & 2061 & 11 & 5.61 & 1.6 & 0.320 & 1.5 & 0.9 \\
\hline 14B47-41.1 & -0.000037 & 0.0615 & -0.064 & 161 & 0.37 & 634 & 9 & & & 0.88 & 2.4 & 0.103 & 1.5 & 0.6 \\
\hline 14B47-42.1 & 0.000067 & 0.0969 & 0.108 & 309 & 0.30 & 1564 & 25 & 1547 & 13 & 3.63 & 1.9 & 0.275 & 1.8 & 0.9 \\
\hline 14B47-43.1 & 0.000039 & 0.1216 & 0.060 & 203 & 0.79 & 1868 & 26 & 1972 & 15 & 5.61 & 1.8 & 0.336 & 1.6 & 0.9 \\
\hline $14 \mathrm{~B} 47-44.1$ & 0.000160 & .0768 & 0.272 & 146 & 0.30 & 1054 & 15 & 1055 & 41 & 1.83 & 2.6 & 0.178 & 1.6 & 0.6 \\
\hline 14B47-45.1 & 0.000054 & 0.0951 & 0.087 & 82 & 0.64 & 1516 & 25 & 1514 & 24 & 3.45 & 2.3 & 0.265 & 1.9 & 0.8 \\
\hline 14B47-46.1 & 0.000018 & 0.0741 & 0.030 & 385 & 0.86 & 1025 & 14 & 1038 & 14 & 1.76 & 1.6 & 0.172 & 1.5 & 0.9 \\
\hline 14B47-47.1 & 0.000111 & 0.0617 & 0.198 & 337 & 0.83 & 610 & 9 & & & 0.82 & 2.4 & 0.099 & 1.5 & 0.6 \\
\hline 14B47-48.1 & 0.000018 & 0.0780 & 0.030 & 258 & 0.19 & 1155 & 16 & 1139 & 15 & 2.10 & 1.7 & 0.196 & 1.5 & 0.9 \\
\hline 14B47-49.1 & 0.000023 & 0.0732 & 0.040 & 147 & 0.35 & 1032 & 15 & 1009 & 24 & 1.74 & 1.9 & 0.174 & 1.5 & 0.8 \\
\hline 14B47-50.1 & 0.000017 & 0.0946 & 0.027 & 132 & 0.66 & 1509 & 21 & 1514 & 15 & 3.43 & 1.8 & 0.264 & 1.6 & 0.9 \\
\hline 14B47-51.1 & 0.000119 & 0.0862 & 0.196 & 169 & 0.45 & 1282 & 18 & 1304 & 26 & 2.56 & 2.0 & 0.220 & 1.5 & 0.8 \\
\hline 14B47-52.1 & -0.000015 & 0.1158 & -0.023 & 114 & 0.73 & 1927 & 26 & 1894 & 12 & 5.57 & 1.7 & 0.348 & 1.5 & 0.9 \\
\hline 14B47-53.1 & 0.000171 & 0.0637 & 0.303 & 512 & 0.76 & 553 & 9 & & & 0.76 & 2.6 & 0.090 & 1.8 & 0.7 \\
\hline 14B47-54.1 & 0.000212 & 0.0626 & 0.377 & 93 & 0.95 & 639 & 10 & & & 0.86 & 5.0 & 0.104 & 1.6 & 0.3 \\
\hline 14B47-55.1 & --- & 0.1270 & 0 & 101 & 1.20 & 2064 & 31 & 2055 & 13 & 6.60 & 1.9 & 0.377 & 1.8 & 0.9 \\
\hline 14B47-56.1 & 0.000036 & 0.0953 & 0.058 & 213 & 0.35 & 1569 & 21 & 1523 & 13 & 3.60 & 1.7 & 0.276 & 1.5 & 0.9 \\
\hline 14B47-57.1 & 0.000069 & 0.0796 & 0.116 & 109 & 0.46 & 1186 & 17 & 1162 & 31 & 2.19 & 2.2 & 0.202 & 1.6 & 0.7 \\
\hline 14B47-58.1 & -0.000057 & 0.0600 & -0.102 & 218 & 0.31 & 600 & 10 & & & 0.82 & 2.6 & 0.097 & 1.8 & 0.7 \\
\hline 14B47-59.1 & -0.000095 & 0.0673 & -0.164 & 133 & 0.60 & 834 & 12 & & & 1.31 & 2.6 & 0.138 & 1.6 & 0.6 \\
\hline 14B47-60.1 & -0.000062 & 0.0640 & -0.108 & 138 & 0.45 & 647 & 9 & & & 0.94 & 2.7 & 0.105 & 1.5 & 0.6 \\
\hline
\end{tabular}

Bowers Mountain Formation (BM) : BM-1 Miramichi Danforth segment. Dill Hill quadrangle, UTM Location $0582145 \mathrm{E} / 5029072 \mathrm{~N}$

\begin{tabular}{|c|c|c|c|c|c|c|c|c|c|c|c|c|c|c|}
\hline 14B34-1.1 & -0.000027 & 0.0841 & -0.044 & 388 & 0.17 & 1506 & 21 & 1302 & 43 & 3.06 & 2.7 & 0.263 & 1.6 & 0.6 \\
\hline 14B34-2.1 & 0.000114 & 0.0573 & 0.205 & 328 & 0.84 & 632 & 7 & & & 0.79 & 5.8 & 0.103 & 1.2 & 0.2 \\
\hline 14B34-3.1 & --- & 0.0823 & 0 & 112 & 0.49 & 1429 & 16 & 1252 & 51 & 2.82 & 2.9 & 0.248 & 1.3 & 0.4 \\
\hline $14 \mathrm{~B} 34-4.1$ & -0.000003 & 0.0664 & -0.005 & 2038 & 0.08 & 1005 & 12 & & & 1.54 & 2.9 & 0.169 & 1.2 & 0.4 \\
\hline 14B34-5.1 & 0.000077 & 0.0740 & 0.131 & 158 & 0.50 & 1306 & 14 & 1009 & 97 & 2.26 & 5.0 & 0.225 & 1.2 & 0.2 \\
\hline $14 \mathrm{~B} 34-6.1$ & --- & 0.0662 & 0 & 202 & 0.84 & 1006 & 11 & & & 1.54 & 1.6 & 0.169 & 1.2 & 0.7 \\
\hline 14B34-7.1 & -0.000009 & 0.0782 & -0.014 & 326 & 0.44 & 1139 & 12 & 1155 & 17 & 2.09 & 1.4 & 0.193 & 1.2 & 0.8 \\
\hline $14 \mathrm{~B} 34-8.1$ & --- & 0.0608 & 0 & 50 & 0.46 & 486 & 11 & & & 0.66 & 4.2 & 0.078 & 2.4 & 0.6 \\
\hline 14B34-9.1 & 0.000361 & 0.0759 & 0.62 & 49 & 0.32 & 946 & 14 & & & 1.54 & 7.9 & 0.158 & 1.6 & 0.2 \\
\hline 14B34-10.1 & 0.000027 & 0.1014 & 0.043 & 220 & 0.39 & 1573 & 16 & 1643 & 16 & 3.85 & 1.5 & 0.276 & 1.2 & 0.8 \\
\hline
\end{tabular}


Appendix C: Continued.

\begin{tabular}{|c|c|c|c|c|c|c|c|c|c|c|c|c|c|c|}
\hline \multirow[b]{2}{*}{ sample $^{1}$} & \multirow[b]{2}{*}{$\begin{array}{l}\text { measured } \\
{ }^{204} \mathrm{~Pb} /{ }^{206} \mathrm{~Pb}\end{array}$} & \multirow[b]{2}{*}{$\begin{array}{l}\text { measured } \\
{ }^{207} \mathrm{~Pb} /{ }^{206} \mathrm{~Pb}\end{array}$} & \multirow[b]{2}{*}{$\begin{array}{l}\text { \%common } \\
{ }^{206} \mathrm{~Pb}\end{array}$} & \multirow[b]{2}{*}{$\begin{array}{c}\mathrm{U} \\
(\mathrm{ppm})\end{array}$} & \multirow[b]{2}{*}{$\mathrm{Th} / \mathrm{U}$} & \multicolumn{4}{|c|}{ Age (Ma) } & \multirow[b]{2}{*}{$\begin{array}{l}{ }^{207} \mathrm{~Pb} / \\
{ }^{235} \mathrm{U}^{5}\end{array}$} & \multirow[b]{2}{*}{$\begin{array}{l}\operatorname{err}^{4} \\
(\%)\end{array}$} & \multirow[b]{2}{*}{$\begin{array}{l}{ }^{206} \mathrm{~Pb} / \\
{ }^{238} \mathrm{U}^{5}\end{array}$} & \multirow[b]{2}{*}{$\begin{array}{l}\text { err }^{4} \\
(\%)\end{array}$} & \multirow[b]{2}{*}{$\begin{array}{l}\text { err. } \\
\text { corr. }\end{array}$} \\
\hline & & & & & & $\begin{array}{l}{ }^{206} \mathrm{~Pb} / \\
{ }^{238} \mathrm{U}^{2}\end{array}$ & $\mathrm{err}^{4}$ & $\begin{array}{l}{ }^{207} \mathrm{~Pb} / \\
{ }^{206} \mathrm{~Pb}^{2,3}\end{array}$ & $\mathrm{err}^{4}$ & & & & & \\
\hline 14B34-11.1 & 0.000110 & 0.0616 & 0.195 & 431 & 0.99 & 603 & 7 & & & 0.81 & 2.5 & 0.098 & 1.1 & 0.5 \\
\hline 14B34-12.1 & 0.000095 & 0.0906 & 0.156 & 92 & 0.93 & 1403 & 17 & 1408 & 52 & 2.99 & 3.1 & 0.243 & 1.4 & 0.4 \\
\hline 14B34-13.1 & 0.000038 & 0.0952 & 0.062 & 206 & 0.57 & 1523 & 16 & 1521 & 37 & 3.48 & 2.3 & 0.267 & 1.2 & 0.5 \\
\hline 14B34-14.1 & -0.000052 & 0.0607 & -0.092 & 114 & 0.37 & 614 & 8 & & & 0.85 & 3.7 & 0.100 & 1.3 & 0.4 \\
\hline 14B34-15.1 & 0.000133 & 0.1047 & 0.211 & 211 & 0.74 & 1594 & 17 & 1675 & 30 & 3.98 & 2.0 & 0.281 & 1.2 & 0.6 \\
\hline 14B34-16.1 & 0.000183 & 0.1811 & 0.252 & 17 & 0.52 & 2596 & 44 & 2642 & 37 & 12.23 & 3.0 & 0.496 & 2.1 & 0.7 \\
\hline 14B34-17.1 & --- & 0.0739 & 0 & 1055 & 0.07 & 1012 & 11 & 1039 & 9 & 1.73 & 1.3 & 0.170 & 1.2 & 0.9 \\
\hline 14B34-18.1 & --- & 0.0675 & 0 & 170 & 0.72 & 744 & 9 & & & 1.14 & 1.9 & 0.122 & 1.3 & 0.7 \\
\hline 14B34-19.1 & 0.000056 & 0.1032 & 0.089 & 439 & 0.42 & 1703 & 17 & 1668 & 12 & 4.27 & 1.3 & 0.302 & 1.1 & 0.9 \\
\hline 14B34-20.1 & 0.000006 & 0.0988 & 0.010 & 302 & 0.31 & 1527 & 16 & 1599 & 14 & 3.64 & 1.4 & 0.267 & 1.2 & 0.8 \\
\hline 14B34-21.1 & 0.000205 & 0.1090 & 0.322 & 129 & 0.52 & 1671 & 18 & 1734 & 32 & 4.33 & 2.2 & 0.296 & 1.2 & 0.6 \\
\hline 14B34-22.1 & 0.000028 & 0.0747 & 0.047 & 1065 & 0.06 & 1038 & 11 & 1049 & 12 & 1.79 & 1.2 & 0.175 & 1.1 & 0.9 \\
\hline 14B34-23.1 & 0.000018 & 0.0955 & 0.029 & 482 & 0.32 & 1435 & 16 & 1532 & 11 & 3.27 & 1.4 & 0.249 & 1.2 & 0.9 \\
\hline $14 \mathrm{~B} 34-24.1$ & --- & 0.0639 & 0 & 95 & 0.81 & 610 & 8 & & & 0.87 & 2.4 & 0.099 & 1.3 & 0.5 \\
\hline 14B34-25.1 & 0.000017 & 0.0989 & 0.028 & 494 & 0.52 & 1518 & 15 & 1599 & 11 & 3.61 & 1.3 & 0.265 & 1.1 & 0.9 \\
\hline 14B34-26.1 & 0.000030 & 0.0974 & 0.048 & 859 & 0.28 & 1502 & 15 & 1565 & 8 & 3.51 & 1.2 & 0.262 & 1.1 & 0.9 \\
\hline 14B34-28.1 & 0.000039 & 0.1271 & 0.058 & 925 & 0.41 & 1879 & 18 & 2050 & 6 & 5.91 & 1.1 & 0.338 & 1.1 & 1.0 \\
\hline 14B34-29.1 & 0.000060 & 0.0963 & 0.096 & 178 & 0.49 & 1457 & 16 & 1538 & 23 & 3.34 & 1.7 & 0.254 & 1.2 & 0.7 \\
\hline 14B34-30.1 & 0.000024 & 0.0966 & 0.038 & 414 & 0.24 & 1520 & 22 & 1552 & 12 & 3.53 & 1.7 & 0.266 & 1.6 & 0.9 \\
\hline 14B34-31.1 & 0.000298 & 0.0866 & 0.495 & 167 & 0.3 & 1231 & 14 & 1255 & 56 & 2.39 & 3.1 & 0.210 & 1.2 & 0.4 \\
\hline $14 \mathrm{~B} 34-32.1$ & -0.000018 & 0.0646 & -0.032 & 257 & 2.17 & 686 & 8 & & & 1.00 & 3.0 & 0.112 & 1.2 & 0.4 \\
\hline 14B34-33.1 & 0.000116 & 0.0981 & 0.186 & 160 & 0.32 & 1565 & 17 & 1557 & 27 & 3.66 & 1.9 & 0.275 & 1.2 & 0.7 \\
\hline 14B34-34.1 & 0.000023 & 0.1521 & 0.034 & 246 & 0.53 & 2459 & 33 & 2366 & 8 & 9.72 & 1.7 & 0.464 & 1.6 & 1.0 \\
\hline 14B34-35.1 & 0.000019 & 0.0958 & 0.031 & 423 & 0.72 & 1471 & 15 & 1538 & 12 & 3.38 & 1.3 & 0.256 & 1.1 & 0.9 \\
\hline 14B34-36.1 & --- & 0.0614 & 0 & 544 & 1.03 & 581 & 11 & & & 0.80 & 2.2 & 0.094 & 2.0 & 0.9 \\
\hline 14B34-37.1 & -0.000012 & 0.0749 & -0.02 & 781 & 0.08 & 1015 & 10 & 1069 & 20 & 1.76 & 1.5 & 0.171 & 1.1 & 0.7 \\
\hline 14B34-38.1 & --- & 0.1070 & 0 & 278 & 0.53 & 1770 & 18 & 1749 & 10 & 4.66 & 1.3 & 0.316 & 1.1 & 0.9 \\
\hline 14B34-39.1 & 0.000020 & 0.0738 & 0.033 & 808 & 0.08 & 1002 & 10 & 1027 & 13 & 1.70 & 1.3 & 0.168 & 1.1 & 0.9 \\
\hline 14B34-40.1 & -0.000012 & 0.0615 & -0.021 & 463 & 0.69 & 611 & 7 & & & 0.85 & 1.6 & 0.099 & 1.1 & 0.7 \\
\hline 14B34-41.1 & -0.000005 & 0.0748 & -0.009 & 1112 & 0.09 & 1021 & 11 & 1063 & 9 & 1.77 & 1.2 & 0.172 & 1.2 & 0.9 \\
\hline 14B34-42.1 & 0.000059 & 0.1081 & 0.092 & 140 & 0.52 & 1713 & 18 & 1753 & 35 & 4.50 & 2.3 & 0.304 & 1.2 & 0.5 \\
\hline 14B34-43.1 & 0.000121 & 0.0959 & 0.195 & 312 & 0.18 & 1532 & 16 & 1512 & 21 & 3.49 & 1.6 & 0.268 & 1.2 & 0.7 \\
\hline 14B34-44.1 & --- & 0.0745 & 0 & 915 & 0.09 & 1054 & 13 & 1053 & 10 & 1.82 & 1.4 & 0.178 & 1.3 & 0.9 \\
\hline 14B34-45.1 & 0.000104 & 0.1940 & 0.141 & 53 & 0.52 & 2739 & 34 & 2765 & 28 & 14.07 & 2.3 & 0.530 & 1.5 & 0.7 \\
\hline 14B34-46.1 & 0.000005 & 0.0937 & 0.008 & 570 & 0.37 & 1500 & 15 & 1499 & 8 & 3.38 & 1.2 & 0.262 & 1.1 & 0.9 \\
\hline 14B34-47.1 & 0.000132 & 0.1154 & 0.204 & 156 & 0.60 & 1800 & 18 & 1857 & 20 & 5.05 & 1.6 & 0.322 & 1.2 & 0.7 \\
\hline 14B34-48.1 & --- & 0.0744 & 0 & 1473 & 0.10 & 962 & 10 & 1051 & 7 & 1.65 & 1.2 & 0.161 & 1.2 & 1.0 \\
\hline 14B34-49.1 & 0.000013 & 0.0747 & 0.022 & 814 & 0.09 & 1042 & 11 & 1053 & 10 & 1.80 & 1.3 & 0.175 & 1.1 & 0.9 \\
\hline 14B34-50.1 & 0.000008 & 0.0985 & 0.013 & 333 & 0.31 & 1568 & 17 & 1593 & 10 & 3.74 & 1.3 & 0.275 & 1.2 & 0.9 \\
\hline 14B34-51.1 & 0.000017 & 0.0939 & 0.028 & 245 & 0.57 & 1510 & 19 & 1500 & 13 & 3.41 & 1.6 & 0.264 & 1.4 & 0.9 \\
\hline 14B34-52.1 & 0.000071 & 0.1159 & 0.109 & 138 & 1.41 & 1886 & 25 & 1878 & 16 & 5.38 & 1.8 & 0.340 & 1.6 & 0.9 \\
\hline 14B34-53.1 & 0.000056 & 0.1091 & 0.087 & 393 & 0.57 & 1659 & 18 & 1772 & 10 & 4.39 & 1.4 & 0.294 & 1.2 & 0.9 \\
\hline 14B34-54.1 & -0.000011 & 0.0998 & -0.018 & 499 & 0.11 & 1565 & 15 & 1623 & 9 & 3.79 & 1.2 & 0.275 & 1.1 & 0.9 \\
\hline 14B34-55.1 & -0.000033 & 0.0803 & -0.056 & 164 & 0.35 & 1203 & 21 & 1215 & 22 & 2.28 & 2.2 & 0.205 & 1.9 & 0.9 \\
\hline 14B34-56.1 & -0.000015 & 0.0618 & -0.027 & 471 & 1.37 & 658 & 8 & & & 0.92 & 1.7 & 0.107 & 1.2 & 0.7 \\
\hline 14B34-57.1 & -0.000031 & 0.0956 & -0.050 & 92 & 0.73 & 1472 & 16 & 1548 & 22 & 3.40 & 1.7 & 0.257 & 1.2 & 0.7 \\
\hline 14B34-58.1 & --- & 0.0946 & 0 & 231 & 0.46 & 1489 & 15 & 1520 & 11 & 3.39 & 1.3 & 0.260 & 1.2 & 0.9 \\
\hline 14B34-59.1 & 0.000004 & 0.0977 & 0.007 & 632 & 0.61 & 1543 & 20 & 1579 & 7 & 3.64 & 1.5 & 0.270 & 1.5 & 1.0 \\
\hline 14B34-60.1 & -0.000010 & 0.1359 & -0.014 & 100 & 0.49 & 2117 & 22 & 2176 & 12 & 7.29 & 1.4 & 0.389 & 1.2 & 0.9 \\
\hline
\end{tabular}


Appendix C: Continued.

\begin{tabular}{|c|c|c|c|c|c|c|c|c|c|c|c|c|c|c|}
\hline \multirow[b]{2}{*}{ sample $^{1}$} & \multirow[b]{2}{*}{$\begin{array}{l}\text { measured } \\
{ }^{204} \mathrm{~Pb} /{ }^{206} \mathrm{~Pb}\end{array}$} & \multirow[b]{2}{*}{$\begin{array}{l}\text { measured } \\
{ }^{207} \mathrm{~Pb} /{ }^{206} \mathrm{~Pb}\end{array}$} & \multirow[b]{2}{*}{$\begin{array}{l}\text { \%common } \\
{ }^{206} \mathrm{~Pb}\end{array}$} & \multirow[b]{2}{*}{$\begin{array}{c}\mathrm{U} \\
(\mathrm{ppm})\end{array}$} & \multirow[b]{2}{*}{$\mathrm{Th} / \mathrm{U}$} & \multicolumn{4}{|c|}{ Age (Ma) } & \multirow[b]{2}{*}{$\begin{array}{l}{ }^{207} \mathrm{~Pb} / \\
{ }^{235} \mathrm{U}^{5}\end{array}$} & \multirow[b]{2}{*}{$\begin{array}{l}\operatorname{err}^{4} \\
(\%)\end{array}$} & \multirow[b]{2}{*}{${ }^{206} \mathrm{~Pb} /$} & \multirow[b]{2}{*}{$\begin{array}{l}\operatorname{err}^{4} \\
(\%)\end{array}$} & \multirow[b]{2}{*}{$\begin{array}{l}\text { err. } \\
\text { corr. }\end{array}$} \\
\hline & & & & & & $\begin{array}{l}{ }^{206} \mathrm{~Pb} / \\
{ }^{238} \mathrm{U}^{2}\end{array}$ & $\mathrm{err}^{4}$ & $\begin{array}{l}{ }^{207} \mathrm{~Pb} / \\
{ }^{206} \mathrm{~Pb}^{2,3}\end{array}$ & $\mathrm{err}^{4}$ & & & & & \\
\hline \multicolumn{15}{|c|}{ ST. CROIX TERRANE } \\
\hline & \multicolumn{14}{|c|}{$\begin{array}{l}\text { Kendall Mountain Formation (KM) : Kl } \\
\text { UTM Location } 0621322 \mathrm{E} / 5003221 \mathrm{~N}\end{array}$} \\
\hline $12 \mathrm{~A} 4 \mathrm{~A}-1.1$ & 0.000008 & 0.0607 & 0.014 & 481 & 0.51 & 660 & 9 & & & 0.9 & 1.7 & 0.108 & 1.4 & 0.8 \\
\hline $12 \mathrm{~A} 4 \mathrm{~A}-2.1$ & 0.000108 & 0.0589 & 0.194 & 167 & 0.70 & 540 & 5 & & & 0.7 & 2.5 & 0.087 & 1.0 & 0.4 \\
\hline $12 \mathrm{~A} 4 \mathrm{~A}-3.1$ & 0.000035 & 0.0743 & 0.060 & 201 & 0.20 & 1009 & 9 & 1034 & 23 & 1.7 & 1.5 & 0.169 & 0.9 & 0.6 \\
\hline $12 \mathrm{~A} 4 \mathrm{~A}-4.1$ & 0.000012 & 0.0659 & 0.021 & 497 & 0.56 & 784 & 7 & & & 1.2 & 1.3 & 0.129 & 1.0 & 0.8 \\
\hline $12 \mathrm{~A} 4 \mathrm{~A}-5.1$ & 0.000073 & 0.0809 & 0.122 & 161 & 0.42 & 1204 & 17 & 1193 & 23 & 2.3 & 1.9 & 0.205 & 1.5 & 0.8 \\
\hline $12 \mathrm{~A} 4 \mathrm{~A}-6.1$ & 0.000092 & 0.0714 & 0.158 & 86 & 0.81 & 954 & 10 & & & 1.5 & 2.4 & 0.159 & 1.2 & 0.5 \\
\hline 12A4A-7.1 & --- & 0.0809 & 0 & 45 & 0.68 & 1262 & 19 & 1218 & 38 & 2.4 & 2.6 & 0.216 & 1.7 & 0.7 \\
\hline $12 \mathrm{~A} 4 \mathrm{~A}-8.1$ & 0.000063 & 0.0769 & 0.106 & 98 & 0.20 & 1195 & 12 & 1095 & 31 & 2.1 & 1.9 & 0.204 & 1.1 & 0.6 \\
\hline 12A4A-9.1 & 0.000010 & 0.0949 & 0.015 & 166 & 0.78 & 1537 & 13 & 1522 & 16 & 3.5 & 1.3 & 0.269 & 1.0 & 0.7 \\
\hline $12 \mathrm{~A} 4 \mathrm{~A}-10.1$ & -0.000027 & 0.0599 & -0.047 & 349 & 0.74 & 561 & 6 & & & 0.8 & 1.8 & 0.091 & 1.2 & 0.7 \\
\hline $12 \mathrm{~A} 4 \mathrm{~A}-11.1$ & 0.000022 & 0.0817 & 0.036 & 190 & 0.58 & 1210 & 16 & 1231 & 20 & 2.3 & 1.8 & 0.206 & 1.5 & 0.8 \\
\hline $12 \mathrm{~A} 4 \mathrm{~A}-12.1$ & -0.000056 & 0.0972 & -0.089 & 87 & 0.50 & 1483 & 25 & 1585 & 24 & 3.5 & 2.2 & 0.259 & 1.9 & 0.8 \\
\hline $12 \mathrm{~A} 4 \mathrm{~A}-13.1$ & -0.000029 & 0.0730 & -0.049 & 165 & 0.31 & 1024 & 9 & 1023 & 25 & 1.7 & 1.6 & 0.172 & 1.0 & 0.6 \\
\hline $12 \mathrm{~A} 4 \mathrm{~A}-14.1$ & --- & 0.0601 & 0 & 178 & 0.78 & 667 & 6 & & & 0.9 & 1.9 & 0.109 & 1.0 & 0.5 \\
\hline $12 \mathrm{~A} 4 \mathrm{~A}-15.1$ & --- & 0.0724 & 0 & 93 & 0.5 & 958 & 10 & & & 1.6 & 2.0 & 0.160 & 1.1 & 0.6 \\
\hline $12 \mathrm{~A} 4 \mathrm{~A}-16.1$ & 0.000113 & 0.0603 & 0.202 & 158 & 0.81 & 651 & 6 & & & 0.9 & 2.5 & 0.106 & 1.0 & 0.4 \\
\hline $12 \mathrm{~A} 4 \mathrm{~A}-17.1$ & 0.000034 & 0.0730 & 0.059 & 278 & 0.39 & 999 & 8 & & & 1.7 & 1.3 & 0.168 & 0.9 & 0.7 \\
\hline $12 \mathrm{~A} 4 \mathrm{~A}-18.1$ & --- & 0.0723 & 0 & 89 & 0.29 & 1003 & 11 & & & 1.7 & 2.0 & 0.168 & 1.2 & 0.6 \\
\hline $12 \mathrm{~A} 4 \mathrm{~A}-19.1$ & 0.000032 & 0.0902 & 0.052 & 325 & 0.28 & 1442 & 17 & 1420 & 13 & 3.1 & 1.5 & 0.251 & 1.3 & 0.9 \\
\hline $12 \mathrm{~A} 4 \mathrm{~A}-20.1$ & 0.000065 & 0.0666 & 0.113 & 239 & 0.11 & 809 & 7 & & & 1.2 & 1.6 & 0.134 & 0.9 & 0.6 \\
\hline 12A $4 \mathrm{~A}-21.1$ & .000035 & .0857 & 0.057 & & 0.36 & 1339 & 22 & 1320 & 25 & 2.7 & 2.2 & 0.231 & 1.8 & 0.8 \\
\hline $12 \mathrm{~A} 4 \mathrm{~A}-22.1$ & 0.000006 & 0.0810 & 0.011 & 317 & 0.40 & 1218 & 10 & 1219 & 15 & 2.3 & 1.1 & 0.208 & 0.9 & 0.8 \\
\hline $12 \mathrm{~A} 4 \mathrm{~A}-23.1$ & 0.000270 & 0.1009 & 0.432 & 122 & 0.41 & 1545 & 15 & 1571 & 28 & 3.6 & 1.9 & 0.271 & 1.1 & 0.6 \\
\hline 12A4A-24.1 & -0.000020 & 0.0600 & -0.036 & 247 & 0.99 & 529 & 5 & & & 0.7 & 1.9 & 0.086 & 0.9 & 0.5 \\
\hline $12 \mathrm{~A} 4 \mathrm{~A}-25.1$ & 0.000067 & 0.0692 & 0.116 & 120 & 0.41 & 928 & 9 & & & 1.5 & 2.0 & 0.155 & 1.1 & 0.5 \\
\hline $12 \mathrm{~A} 4 \mathrm{~A}-26.1$ & --- & 0.0785 & 0 & 96 & 0.36 & 1081 & 12 & 1158 & 36 & 2.0 & 2.2 & 0.183 & 1.2 & 0.6 \\
\hline $12 \mathrm{~A} 4 \mathrm{~A}-27.1$ & -0.000033 & 0.0625 & -0.058 & 103 & 0.93 & 871 & 40 & & & 1.3 & 5.3 & 0.145 & 4.9 & 0.9 \\
\hline $12 \mathrm{~A} 4 \mathrm{~A}-28.1$ & 0.000066 & 0.0671 & 0.115 & 291 & 0.69 & 789 & 25 & & & 1.2 & 3.7 & 0.130 & 3.4 & 0.9 \\
\hline $12 \mathrm{~A} 4 \mathrm{~A}-29.1$ & 0.000015 & 0.0995 & 0.024 & 240 & 0.36 & 1736 & 316 & 1609 & 240 & 4.2 & 24.4 & 0.309 & 20.8 & 0.8 \\
\hline $12 \mathrm{~A} 4 \mathrm{~A}-30.1$ & .000006 & 0.0915 & 0.010 & 310 & 0.27 & 1327 & 28 & 1454 & 16 & 2.9 & 2.5 & 0.228 & 2.4 & 0.9 \\
\hline $12 \mathrm{~A} 4 \mathrm{~A}-31.1$ & 0.000034 & 0.0729 & 0.058 & 138 & 0.29 & 1009 & 52 & & & 1.7 & 5.7 & 0.169 & 5.5 & 1.0 \\
\hline $12 \mathrm{~A} 4 \mathrm{~A}-32.1$ & -0.000074 & 0.0731 & -0.126 & 65 & 0.31 & 1025 & 12 & 1043 & 43 & 1.8 & 2.5 & 0.172 & 1.3 & 0.5 \\
\hline $12 \mathrm{~A} 4 \mathrm{~A}-33.1$ & -0.000018 & 0.1146 & -0.028 & 86 & 0.83 & 1866 & 37 & 1877 & 20 & 5.3 & 2.6 & 0.336 & 2.3 & 0.9 \\
\hline $12 \mathrm{~A} 4 \mathrm{~A}-34.1$ & -0.000051 & 0.0613 & -0.089 & 83 & 0.32 & 664 & 14 & & & 0.9 & 3.4 & 0.108 & 2.2 & 0.6 \\
\hline $12 \mathrm{~A} 4 \mathrm{~A}-35.1$ & 0.000104 & 0.0629 & 0.183 & 103 & 0.44 & 710 & 8 & & & 1.0 & 4.0 & 0.116 & 1.1 & 0.3 \\
\hline $12 \mathrm{~A} 4 \mathrm{~A}-36.1$ & 0.000110 & 0.0600 & 0.196 & 76 & 0.62 & 616 & 7 & & & 0.8 & 3.9 & 0.100 & 1.2 & 0.3 \\
\hline $12 \mathrm{~A} 4 \mathrm{~A}-37.1$ & -0.000013 & 0.0894 & -0.021 & 136 & 0.25 & 1404 & 13 & 1416 & 20 & 3.0 & 1.5 & 0.243 & 1.0 & 0.7 \\
\hline $12 \mathrm{~A} 4 \mathrm{~A}-38.1$ & --- & 0.0904 & 0 & 149 & 0.32 & 1456 & 13 & 1433 & 18 & 3.2 & 1.4 & 0.253 & 1.0 & 0.7 \\
\hline $12 \mathrm{~A} 4 \mathrm{~A}-39.1$ & 0.000014 & 0.1168 & 0.022 & 89 & 1.07 & 1878 & 19 & 1904 & 18 & 5.4 & 1.5 & 0.338 & 1.2 & 0.8 \\
\hline $12 \mathrm{~A} 4 \mathrm{~A}-40.1$ & 0.000040 & 0.0673 & 0.069 & 101 & 0.72 & 629 & 7 & & & 0.9 & 2.9 & 0.102 & 1.1 & 0.4 \\
\hline $12 \mathrm{~A} 4 \mathrm{~A}-41.1$ & -0.000015 & 0.1262 & -0.022 & 160 & 0.52 & 2029 & 17 & 2048 & 12 & 6.4 & 1.2 & 0.370 & 1.0 & 0.8 \\
\hline $12 \mathrm{~A} 4 \mathrm{~A}-42.1$ & -0.000081 & 0.1431 & -0.118 & 61 & 0.80 & 2354 & 28 & 2276 & 20 & 8.8 & 1.8 & 0.441 & 1.4 & 0.8 \\
\hline $12 \mathrm{~A} 4 \mathrm{~A}-43.1$ & 0.000011 & 0.0810 & 0.018 & 812 & 0.19 & 1232 & 9 & 1216 & 10 & 2.3 & 0.9 & 0.211 & 0.8 & 0.8 \\
\hline $12 \mathrm{~A} 4 \mathrm{~A}-44.1$ & -0.000062 & 0.0642 & -0.109 & 109 & 1.99 & 817 & 9 & & & 1.2 & 2.4 & 0.135 & 1.1 & 0.5 \\
\hline $12 \mathrm{~A} 4 \mathrm{~A}-45.1$ & -0.000020 & 0.0860 & -0.033 & 89 & 1.35 & 1310 & 14 & 1344 & 26 & 2.7 & 1.8 & 0.225 & 1.2 & 0.7 \\
\hline $12 \mathrm{~A} 4 \mathrm{~A}-46.1$ & -0.000231 & 0.0595 & -0.406 & 60 & 1.06 & 559 & 7 & & & 0.8 & 4.4 & 0.091 & 1.4 & 0.3 \\
\hline
\end{tabular}


Appendix C: Continued.

\begin{tabular}{|c|c|c|c|c|c|c|c|c|c|c|c|c|c|c|}
\hline \multirow[b]{2}{*}{ sample $^{1}$} & \multirow[b]{2}{*}{$\begin{array}{l}\text { measured } \\
{ }^{204} \mathrm{~Pb} /{ }^{206} \mathrm{~Pb}\end{array}$} & \multirow[b]{2}{*}{$\begin{array}{l}\text { measured } \\
{ }^{207} \mathrm{~Pb} /{ }^{206} \mathrm{~Pb}\end{array}$} & \multirow[b]{2}{*}{$\begin{array}{l}\text { \%common } \\
{ }^{206} \mathrm{~Pb}\end{array}$} & \multirow[b]{2}{*}{$\begin{array}{c}\mathrm{U} \\
(\mathrm{ppm})\end{array}$} & \multirow[b]{2}{*}{$\mathrm{Th} / \mathrm{U}$} & \multicolumn{4}{|c|}{ Age (Ma) } & \multirow[b]{2}{*}{$\begin{array}{l}{ }^{207} \mathrm{~Pb} / \\
{ }^{235} \mathrm{U}^{5}\end{array}$} & \multirow[b]{2}{*}{$\begin{array}{l}\mathrm{err}^{4} \\
(\%)\end{array}$} & \multirow[b]{2}{*}{$\begin{array}{l}{ }^{206} \mathrm{~Pb} / \\
{ }^{238} \mathrm{U}^{5}\end{array}$} & \multirow[b]{2}{*}{$\begin{array}{l}\mathrm{err}^{4} \\
(\%)\end{array}$} & \multirow[b]{2}{*}{$\begin{array}{l}\text { err. } \\
\text { corr. }\end{array}$} \\
\hline & & & & & & $\begin{array}{l}{ }^{206} \mathrm{~Pb} / \\
{ }^{238} \mathrm{U}^{2}\end{array}$ & $e^{4} r^{4}$ & $\begin{array}{l}{ }^{207} \mathrm{~Pb} / \\
{ }^{206} \mathrm{~Pb}^{2,3}\end{array}$ & $\mathrm{err}^{4}$ & & & & & \\
\hline $12 \mathrm{~A} 4 \mathrm{~A}-47.1$ & 0.000118 & 0.0612 & 0.210 & 145 & 0.62 & 618 & 10 & & & 0.8 & 2.9 & 0.101 & 1.6 & 0.6 \\
\hline $12 \mathrm{~A} 4 \mathrm{~A}-48.1$ & -0.000010 & 0.1358 & -0.015 & 112 & 0.50 & 2126 & 21 & 2175 & 13 & 7.3 & 1.4 & 0.391 & 1.1 & 0.8 \\
\hline $12 \mathrm{~A} 4 \mathrm{~A}-49.1$ & --- & 0.0965 & 0 & 105 & 0.51 & 1564 & 16 & 1557 & 36 & 3.7 & 2.2 & 0.275 & 1.1 & 0.5 \\
\hline $12 \mathrm{~A} 4 \mathrm{~A}-50.1$ & 0.000230 & 0.0698 & 0.400 & 200 & 0.71 & 796 & 7 & & & 1.2 & 2.1 & 0.131 & 0.9 & 0.5 \\
\hline 12A $4 \mathrm{~A}-51.1$ & 0.000026 & 0.0606 & 0.045 & 221 & 0.82 & 497 & 44 & & & 0.7 & 10.1 & 0.080 & 9.2 & 0.9 \\
\hline $12 \mathrm{~A} 4 \mathrm{~A}-52.1$ & --- & 0.0702 & 0 & 515 & 0.35 & 928 & 12 & & & 1.5 & 1.6 & 0.155 & 1.4 & 0.9 \\
\hline $12 \mathrm{~A} 4 \mathrm{~A}-53.1$ & -0.000007 & 0.0823 & -0.012 & 272 & 0.97 & 1229 & 22 & 1255 & 16 & 2.4 & 2.1 & 0.210 & 2.0 & 0.9 \\
\hline $12 \mathrm{~A} 4 \mathrm{~A}-54.1$ & 0.000006 & 0.1836 & 0.009 & 128 & 0.39 & 2726 & 26 & 2685 & 10 & 13.3 & 1.3 & 0.526 & 1.2 & 0.9 \\
\hline $12 \mathrm{~A} 4 \mathrm{~A}-55.1$ & -0.000061 & 0.1196 & -0.093 & 80 & 1.57 & 1962 & 21 & 1962 & 18 & 5.9 & 1.6 & 0.356 & 1.2 & 0.8 \\
\hline $12 \mathrm{~A} 4 \mathrm{~A}-56.1$ & -0.000067 & 0.0709 & -0.115 & 113 & 0.39 & 955 & 11 & & & 1.6 & 2.1 & 0.160 & 1.2 & 0.6 \\
\hline $12 \mathrm{~A} 4 \mathrm{~A}-57.1$ & --- & 0.0566 & 0 & 82 & 1.53 & 549 & 6 & & & 0.7 & 3.0 & 0.089 & 1.2 & 0.4 \\
\hline $12 \mathrm{~A} 4 \mathrm{~A}-58.1$ & 0.000027 & 0.0603 & 0.047 & 157 & 0.81 & 631 & 9 & & & 0.8 & 2.4 & 0.103 & 1.5 & 0.6 \\
\hline $12 \mathrm{~A} 4 \mathrm{~A}-59.1$ & 0.000039 & 0.0660 & 0.068 & 278 & 0.43 & 796 & 7 & & & 1.2 & 2.4 & 0.131 & 1.0 & 0.4 \\
\hline $12 \mathrm{~A} 4 \mathrm{~A}-60.1$ & --- & 0.0608 & 0 & 143 & 0.27 & 601 & 16 & & & 0.8 & 3.4 & 0.098 & 2.8 & 0.8 \\
\hline $12 \mathrm{~A} 4 \mathrm{~A}-61.1$ & --- & 0.0843 & 0 & 128 & 0.43 & 1356 & 14 & 1299 & 22 & 2.7 & 1.6 & 0.234 & 1.2 & 0.7 \\
\hline $12 \mathrm{~A} 4 \mathrm{~A}-62.1$ & --- & 0.0673 & 0 & 238 & 0.75 & 861 & 7 & & & 1.3 & 1.4 & 0.143 & 0.9 & 0.6 \\
\hline $12 \mathrm{~A} 4 \mathrm{~A}-63.1$ & 0.000057 & 0.0717 & 0.098 & 93 & 0.48 & 898 & 27 & & & 1.5 & 3.7 & 0.149 & 3.2 & 0.9 \\
\hline $12 \mathrm{~A} 4 \mathrm{~A}-64.1$ & 0.000023 & 0.1246 & 0.035 & 274 & 0.44 & 1904 & 15 & 2018 & 12 & 5.9 & 1.1 & 0.344 & 0.9 & 0.8 \\
\hline $12 \mathrm{~A} 4 \mathrm{~A}-65.1$ & 0.000055 & 0.0601 & 0.098 & 79 & 0.81 & 625 & 7 & & & 0.8 & 3.1 & 0.102 & 1.2 & 0.4 \\
\hline $12 \mathrm{~A} 4 \mathrm{~A}-66.1$ & 0.000011 & 0.1076 & 0.018 & 132 & 0.87 & 1770 & 17 & 1756 & 16 & 4.7 & 1.4 & 0.316 & 1.1 & 0.8 \\
\hline $12 \mathrm{~A} 4 \mathrm{~A}-67.1$ & -0.000032 & 0.0787 & -0.053 & 60 & 0.45 & 1267 & 37 & 1174 & 35 & 2.4 & 3.6 & 0.217 & 3.2 & 0.9 \\
\hline $12 \mathrm{~A} 4 \mathrm{~A}-68.1$ & 0.000007 & 0.2420 & 0.009 & 176 & 0.45 & 3217 & 24 & 3132 & 6 & 21.6 & 1.0 & 0.647 & 1.0 & 0.9 \\
\hline $12 \mathrm{~A} 4 \mathrm{~A}-69.1$ & 0.000012 & 0.1075 & 0.018 & 104 & 0.73 & 1783 & 17 & 1754 & 17 & 4.7 & 1.4 & 0.319 & 1.1 & 0.8 \\
\hline $12 \mathrm{~A} 4 \mathrm{~A}-70.1$ & 0.000017 & 0.0962 & 0.028 & 257 & 0.66 & 1572 & 12 & 1546 & 13 & 3.7 & 1.1 & 0.276 & 0.9 & 0.8 \\
\hline
\end{tabular}

POST-MIDDLE ORDOVICIAN COVER ROCK UNITS

FREDERICTON TROUGH AND CORRELATIVES

Flume Ridge Formation (FR) : FR-1 Eastern facies, Kellyland dam. Kellyland quadrangle, UTM Location 0619272E/5014389N

\begin{tabular}{|c|c|c|c|c|c|c|c|c|c|c|c|c|c|c|}
\hline FR-1-12-1.1 & --- & 0.0740 & 0 & 106 & 0.33 & 1066 & 11 & 1042 & 34 & 1.8 & 2.0 & 0.180 & 1.1 & 0.6 \\
\hline FR-1-12-2.1 & 0.000032 & 0.0583 & 0.059 & 614 & 0.72 & 430 & 3 & & & 0.6 & 1.5 & 0.069 & 0.7 & 0.4 \\
\hline FR-1-12-3.1 & -0.000018 & 0.0822 & -0.034 & 289 & 0.01 & 1233 & 17 & 1256 & 28 & 2.4 & 2.1 & 0.211 & 1.5 & 0.7 \\
\hline FR-1-12-4.1 & --- & 0.0568 & 0 & 796 & 0.53 & 438 & 6 & & & 0.5 & 1.8 & 0.070 & 1.4 & 0.8 \\
\hline FR-1-12-5.1 & -0.000026 & 0.0773 & -0.048 & 152 & 0.33 & 1053 & 10 & 1139 & 30 & 1.9 & 1.8 & 0.177 & 1.0 & 0.6 \\
\hline FR-1-12-6.1 & -0.000021 & 0.0786 & -0.039 & 196 & 0.83 & 1210 & 18 & 1168 & 26 & 2.2 & 2.1 & 0.206 & 1.6 & 0.8 \\
\hline FR-1-12-7.1 & 0.000057 & 0.0746 & 0.104 & 137 & 0.98 & 1085 & 18 & 1036 & 35 & 1.9 & 2.5 & 0.183 & 1.8 & 0.7 \\
\hline FR-1-12-8.1 & 0.000004 & 0.0797 & 0.008 & 661 & 0.17 & 1186 & 14 & 1187 & 11 & 2.2 & 1.4 & 0.202 & 1.2 & 0.9 \\
\hline FR-1-12-9.1 & 0.000012 & 0.0753 & 0.023 & 467 & 0.20 & 1071 & 12 & 1071 & 14 & 1.9 & 1.4 & 0.181 & 1.2 & 0.9 \\
\hline FR-1-12-10.1 & 0.000006 & 0.1133 & 0.011 & 294 & 0.24 & 1825 & 31 & 1852 & 11 & 5.1 & 2.0 & 0.327 & 2.0 & 1.0 \\
\hline FR-1-12-11.1 & 0.000118 & 0.0552 & 0.216 & 258 & 0.81 & 427 & 8 & & & 0.5 & 3.5 & 0.068 & 2.0 & 0.6 \\
\hline FR-1-12-12.1 & 0.000238 & 0.0552 & 0.435 & 164 & 0.65 & 477 & 5 & & & 0.5 & 4.4 & 0.077 & 1.0 & 0.2 \\
\hline FR-1-12-13.1 & 0.000020 & 0.0571 & 0.036 & 1028 & 0.35 & 471 & 3 & & & 0.6 & 1.1 & 0.076 & 0.6 & 0.6 \\
\hline FR-1-12-14.1 & 0.000020 & 0.0556 & 0.036 & 1009 & 0.57 & 433 & 3 & & & 0.5 & 1.3 & 0.070 & 0.6 & 0.5 \\
\hline FR-1-12-15.1 & 0.000007 & 0.0781 & 0.013 & 455 & 0.38 & 1137 & 7 & 1146 & 15 & 2.1 & 1.0 & 0.193 & 0.7 & 0.7 \\
\hline FR-1-12-16.1 & 0.000251 & 0.0553 & 0.459 & 209 & 1.12 & 424 & 4 & & & 0.5 & 4.6 & 0.068 & 1.0 & 0.2 \\
\hline FR-1-12-17.1 & --- & 0.0855 & 0 & 348 & 0.35 & 1358 & 10 & 1326 & 26 & 2.8 & 1.6 & 0.234 & 0.8 & 0.5 \\
\hline FR-1-12-18.1 & 0.000028 & 0.0556 & 0.051 & 696 & 0.99 & 433 & 8 & & & 0.5 & 2.3 & 0.069 & 1.9 & 0.8 \\
\hline FR-1-12-19.1 & -0.000141 & 0.0565 & -0.257 & 62 & 1.01 & 454 & 6 & & & 0.6 & 5.3 & 0.073 & 1.5 & 0.3 \\
\hline FR-1-12-20.1 & -0.000010 & 0.0734 & -0.019 & 337 & 0.35 & 1023 & 7 & 1028 & 19 & 1.7 & 1.2 & 0.172 & 0.7 & 0.6 \\
\hline FR-1-12-21.1 & -0.000003 & 0.1072 & -0.006 & 597 & 0.27 & 1679 & 10 & 1754 & 8 & 4.4 & 0.8 & 0.298 & 0.6 & 0.8 \\
\hline
\end{tabular}


Appendix C: Continued.

\begin{tabular}{|c|c|c|c|c|c|c|c|c|c|c|c|c|c|c|}
\hline \multirow[b]{2}{*}{ sample $^{1}$} & \multirow[b]{2}{*}{$\begin{array}{c}\text { measured } \\
{ }^{204} \mathrm{~Pb} /{ }^{206} \mathrm{~Pb}\end{array}$} & \multirow[b]{2}{*}{$\begin{array}{l}\text { measured } \\
{ }^{207} \mathrm{~Pb} /{ }^{206} \mathrm{~Pb}\end{array}$} & \multirow[b]{2}{*}{$\begin{array}{l}\text { \%common } \\
{ }^{206} \mathrm{~Pb}\end{array}$} & \multirow[b]{2}{*}{$\begin{array}{c}\mathrm{U} \\
(\mathrm{ppm})\end{array}$} & \multirow[b]{2}{*}{$\mathrm{Th} / \mathrm{U}$} & \multicolumn{4}{|c|}{ Age (Ma) } & \multirow[b]{2}{*}{$\begin{array}{l}{ }^{207} \mathrm{~Pb} / \\
{ }^{235} \mathrm{U}^{5}\end{array}$} & \multirow[b]{2}{*}{$\begin{array}{l}\operatorname{err}^{4} \\
(\%)\end{array}$} & \multirow[b]{2}{*}{$\begin{array}{l}{ }^{206} \mathrm{~Pb} / \\
{ }^{238} \mathrm{U}^{5}\end{array}$} & \multirow[b]{2}{*}{$\begin{array}{l}\text { err }^{4} \\
(\%)\end{array}$} & \multirow[b]{2}{*}{$\begin{array}{l}\text { err. } \\
\text { corr. }\end{array}$} \\
\hline & & & & & & $\begin{array}{l}{ }^{206} \mathrm{~Pb} / \\
{ }^{238} \mathrm{U}^{2}\end{array}$ & $\mathrm{err}^{4}$ & $\begin{array}{c}{ }^{207} \mathrm{~Pb} / \\
{ }^{206} \mathrm{~Pb}^{2,3}\end{array}$ & err $^{4}$ & & & & & \\
\hline FR-1-12-22.1 & 0.000008 & 0.0748 & 0.014 & 510 & 0.60 & 1050 & 11 & 1060 & 16 & 1.8 & 1.4 & 0.177 & 1.1 & 0.8 \\
\hline FR-1-12-23.1 & 0.000078 & 0.0816 & 0.143 & 319 & 0.40 & 1080 & 9 & 1208 & 21 & 2.0 & 1.4 & 0.182 & 0.9 & 0.6 \\
\hline FR-1-12-24.1 & -0.000006 & 0.0915 & -0.011 & 434 & 0.53 & 1446 & 9 & 1459 & 12 & 3.2 & 1.0 & 0.251 & 0.7 & 0.7 \\
\hline FR-1-12-25.1 & 0.000025 & 0.0763 & 0.045 & 507 & 0.30 & 1099 & 14 & 1094 & 15 & 1.9 & 1.5 & 0.186 & 1.4 & 0.9 \\
\hline FR-1-12-26.1 & 0.000015 & 0.0784 & 0.027 & 556 & 0.08 & 1160 & 12 & 1153 & 13 & 2.1 & 1.3 & 0.197 & 1.2 & 0.9 \\
\hline FR-1-12-27.1 & --- & 0.0916 & 0 & 203 & 0.49 & 1407 & 11 & 1458 & 17 & 3.1 & 1.3 & 0.244 & 0.9 & 0.7 \\
\hline FR-1-12-28.1 & 0.000028 & 0.1183 & 0.051 & 310 & 0.38 & 1892 & 12 & 1925 & 10 & 5.5 & 0.9 & 0.341 & 0.8 & 0.8 \\
\hline FR-1-12-29.1 & 0.000009 & 0.0770 & 0.017 & 357 & 0.25 & 1100 & 7 & 1119 & 34 & 2.0 & 1.9 & 0.186 & 0.7 & 0.4 \\
\hline FR-1-12-30.1 & --- & 0.0766 & 0 & 50 & 0.84 & 1103 & 18 & 1110 & 53 & 2.0 & 3.2 & 0.187 & 1.8 & 0.6 \\
\hline FR-1-12-31.1 & 0.000049 & 0.1024 & 0.089 & 237 & 0.88 & 1651 & 14 & 1656 & 17 & 4.1 & 1.3 & 0.292 & 0.9 & 0.7 \\
\hline FR-1-12-32.1 & 0.000088 & 0.0588 & 0.162 & 124 & 0.37 & 446 & 5 & & & 0.6 & 3.9 & 0.072 & 1.2 & 0.3 \\
\hline FR-1-12-33.1 & -0.000004 & 0.1003 & -0.007 & 958 & 0.43 & 1636 & 9 & 1631 & 7 & 4.0 & 0.7 & 0.289 & 0.6 & 0.9 \\
\hline FR-1-12-34.1 & 0.000009 & 0.0558 & 0.016 & 1137 & 0.39 & 430 & 3 & & & 0.5 & 1.3 & 0.069 & 0.8 & 0.6 \\
\hline FR-1-12-35.1 & 0.000021 & 0.1051 & 0.039 & 201 & 0.66 & 1693 & 13 & 1712 & 15 & 4.3 & 1.2 & 0.300 & 0.9 & 0.7 \\
\hline FR-1-12-36.1 & --- & 1068 & 0 & 248 & 0.24 & 1717 & 13 & 1746 & 13 & 4.5 & 1.1 & 0.305 & 0.8 & 0.8 \\
\hline FR-1-12-37.1 & -0.000054 & 0.1118 & -0.099 & 99 & 0.61 & 1814 & 21 & 1840 & 24 & 5.0 & 1.9 & 0.325 & 1.3 & 0.7 \\
\hline FR-1-12-38.1 & 0.000018 & 0.0753 & 0.033 & 412 & 0.32 & 1091 & 7 & 1071 & 18 & 1.9 & 1.1 & 0.184 & 0.7 & 0.6 \\
\hline FR-1-12-39.1 & 0.000028 & 0.1017 & 0.051 & 198 & 1.19 & 1637 & 36 & 1648 & 18 & 4.0 & 2.7 & 0.289 & 2.5 & 0.9 \\
\hline FR-1-12-40.1 & 0.000017 & 0.2015 & 0.031 & 83 & 0.78 & 2864 & 31 & 2837 & 13 & 15.5 & 1.6 & 0.559 & 1.3 & 0.9 \\
\hline FR-1-12-41.1 & -0.000011 & 0775 & -0.020 & 362 & 0.32 & 1107 & 16 & 1139 & 18 & 2.0 & 1.8 & 0.187 & 1.5 & 0.9 \\
\hline FR-1-12-42.1 & --- & 0.0789 & 0 & 234 & 0.40 & 1138 & 9 & 1169 & 20 & 2.1 & 1.3 & 0.193 & 0.8 & 0.6 \\
\hline FR-1-12-43.1 & 0.000538 & 0.1113 & 0.984 & 1293 & 0.27 & 1585 & 13 & 1695 & 19 & 4.0 & 1.4 & 0.279 & 1.0 & 0.7 \\
\hline FR-1-12-44.1 & -0.000027 & 0.0956 & -0.050 & 190 & 0.73 & 1558 & 13 & 1547 & 18 & 3.6 & 1.4 & 0.273 & 1.0 & 0.7 \\
\hline FR-1-12-45.1 & --- & 0.0741 & 0 & 1118 & 0.27 & 1039 & 13 & 1045 & 9 & 1.8 & 1.4 & 0.175 & 1.3 & 0.9 \\
\hline FR-1-12-46.1 & --- & .0551 & 0 & 180 & 0.70 & 450 & 5 & & & 0.5 & 2.6 & 0.072 & 1.1 & 0.4 \\
\hline FR-1-12-47.1 & 0.000195 & 0.0730 & 0.357 & 77 & 0.75 & 967 & 12 & & & 1.6 & 3.6 & 0.162 & 1.4 & 0.4 \\
\hline FR-1-12-48.1 & -0.000013 & 0.0916 & -0.024 & 451 & 0.28 & 1453 & 9 & 1462 & 13 & 3.2 & 1.0 & 0.253 & 0.7 & 0.7 \\
\hline FR-1-12-49.1 & 0.000285 & 0.0730 & 0.521 & 21 & 0.00 & 1056 & 21 & & & 1.7 & 5.9 & 0.178 & 2.1 & 0.4 \\
\hline FR-1-12-50.1 & 0.000015 & 0.0790 & 0.028 & 736 & 1.20 & 1140 & 10 & 1167 & 13 & 2.1 & 1.1 & 0.193 & 0.9 & 0.8 \\
\hline FR-1-12-51.1 & 0.000010 & 0.0798 & 0.018 & 364 & 0.52 & 1200 & 24 & 1189 & 17 & 2.2 & 2.4 & 0.205 & 2.2 & 0.9 \\
\hline FR-1-12-52.1 & 0.000006 & 0.0857 & 0.011 & 772 & 0.37 & 1345 & 15 & 1329 & 9 & 2.7 & 1.4 & 0.232 & 1.3 & 0.9 \\
\hline FR-1-12-53.1 & --- & 0.0582 & 0 & 357 & 0.51 & 462 & 3 & & & 0.6 & 1.7 & 0.074 & 0.8 & 0.4 \\
\hline FR-1-12-54.1 & -0.000134 & 0.0556 & -0.246 & 308 & 0.35 & 464 & 4 & & & 0.6 & 2.6 & 0.075 & 0.8 & 0.3 \\
\hline FR-1-12-55.1 & 0.000008 & 0.0914 & 0.015 & 613 & 0.45 & 1479 & 26 & 1453 & 10 & 3.2 & 2.1 & 0.258 & 2.0 & 1.0 \\
\hline FR-1-12-56.1 & --- & 0.0838 & 0 & 156 & 0.37 & 1269 & 11 & 1288 & 24 & 2.5 & 1.6 & 0.218 & 1.0 & 0.6 \\
\hline FR-1-12-57.1 & 0.000100 & 0.0745 & 0.184 & 83 & 0.76 & 1080 & 13 & 1017 & 50 & 1.8 & 2.8 & 0.182 & 1.3 & 0.5 \\
\hline FR-1-12-58.1 & 0.000023 & 0.0897 & 0.042 & 267 & 0.50 & 1455 & 11 & 1412 & 39 & 3.1 & 2.2 & 0.253 & 0.9 & 0.4 \\
\hline FR-1-12-59.1 & 0.000024 & 0.1018 & 0.043 & 194 & 0.83 & 1662 & 13 & 1652 & 16 & 4.1 & 1.3 & 0.294 & 0.9 & 0.7 \\
\hline FR-1-12-60.1 & 0.000048 & 0.0783 & 0.088 & 337 & 0.35 & 1149 & 8 & 1137 & 19 & 2.1 & 1.2 & 0.195 & 0.7 & 0.6 \\
\hline
\end{tabular}

Flume Ridge Formation (FR) : FR-2 Western facies, near fault contact with Miramichi terrane. Tomah Mountain quadrangle, UTM Location 0599839E/5030305N

$\begin{array}{lcrrrrrr}\text { FR-2euh-1.1 } & --- & 0.0561 & -0.616 & 99 & 0.58 & 639 & 12 \\ \text { FR-2euh-2.1 } & 0.000069 & 0.0600 & 0.030 & 123 & 1.33 & 595 & 17 \\ \text { FR-2euh-3.1 } & --- & 0.0598 & -0.048 & 79 & 0.66 & 608 & 12 \\ \text { FR-2euh-4.1 } & 0.000046 & 0.0578 & -0.134 & 193 & 1.25 & 563 & 9 \\ \text { FR-2euh-5.1 } & -0.000048 & 0.0563 & 0.005 & 210 & 0.36 & 461 & 10 \\ \text { FR-2euh-6.1 } & --- & 0.0529 & -0.462 & 59 & 0.87 & 475 & 11 \\ \text { FR-2euh-7.1 } & 0.000068 & 0.0592 & -0.109 & 213 & 0.71 & 607 & 10 \\ \text { FR-2euh-8.1 } & 0.000025 & 0.056 & -0.034 & 343 & 0.89 & 461 & 13\end{array}$

$\begin{array}{lllll}0.81 & 3.8 & 0.104 & 2.0 & 0.5 \\ 0.79 & 4.2 & 0.097 & 3.0 & 0.7 \\ 0.82 & 3.5 & 0.099 & 2.1 & 0.6 \\ 0.72 & 2.9 & 0.091 & 1.8 & 0.6 \\ 0.58 & 3.2 & 0.074 & 2.2 & 0.7 \\ 0.56 & 5.0 & 0.077 & 2.3 & 0.5 \\ 0.79 & 2.7 & 0.099 & 1.7 & 0.6 \\ 0.57 & 5.2 & 0.074 & 3.0 & 0.6\end{array}$


Appendix C: Continued.

\begin{tabular}{|c|c|c|c|c|c|c|c|c|c|c|c|c|c|c|}
\hline \multirow[b]{2}{*}{ sample ${ }^{1}$} & \multirow[b]{2}{*}{$\begin{array}{c}\text { measured } \\
{ }^{204} \mathrm{~Pb} /{ }^{206} \mathrm{~Pb}\end{array}$} & \multirow[b]{2}{*}{$\begin{array}{l}\text { measured } \\
{ }^{207} \mathrm{~Pb} /{ }^{206} \mathrm{~Pb}\end{array}$} & \multirow[b]{2}{*}{$\begin{array}{l}\text { \%common } \\
{ }^{206} \mathrm{~Pb}\end{array}$} & \multirow[b]{2}{*}{$\begin{array}{c}\mathrm{U} \\
(\mathrm{ppm})\end{array}$} & \multirow[b]{2}{*}{$\mathrm{Th} / \mathrm{U}$} & \multicolumn{4}{|c|}{ Age (Ma) } & \multirow[b]{2}{*}{$\begin{array}{l}{ }^{207} \mathrm{~Pb} / \\
{ }^{235} \mathrm{U}^{5}\end{array}$} & \multirow[b]{2}{*}{$\begin{array}{l}\text { err }^{4} \\
(\%)\end{array}$} & \multirow[b]{2}{*}{$\begin{array}{l}{ }^{206} \mathrm{~Pb} / \\
{ }^{238} \mathrm{U}^{5}\end{array}$} & \multirow[b]{2}{*}{$\begin{array}{l}\mathrm{err}^{4} \\
(\%)\end{array}$} & \multirow[b]{2}{*}{$\begin{array}{l}\text { err. } \\
\text { corr. }\end{array}$} \\
\hline & & & & & & $\begin{array}{l}{ }^{206} \mathrm{~Pb} / \\
{ }^{238} \mathrm{U}^{2}\end{array}$ & $\mathrm{err}^{4}$ & $\begin{array}{l}{ }^{207} \mathrm{~Pb} / \\
{ }^{206} \mathrm{~Pb}^{2,3}\end{array}$ & $\mathrm{err}^{4}$ & & & & & \\
\hline FR-2euh-9.1 & -0.000088 & 0.0558 & -0.055 & 116 & 0.45 & 464 & 9 & & & 0.59 & 4.0 & 0.075 & 1.9 & 0.5 \\
\hline FR-2euh-10.1 & --- & 0.0578 & 0.245 & 85 & 0.70 & 445 & 15 & & & 0.57 & 4.8 & 0.071 & 3.5 & 0.7 \\
\hline FR-2euh-11.1 & --- & 0.0558 & -0.045 & 504 & 0.46 & 457 & 7 & & & 0.56 & 2.2 & 0.073 & 1.6 & 0.8 \\
\hline FR-2-1.1 & 0.000073 & 0.0589 & 0.258 & 148 & 0.54 & 486 & 12 & & & 0.63 & 4.1 & 0.078 & 2.6 & 0.6 \\
\hline FR-2-2.1 & 0.000072 & 0.1002 & -0.281 & 113 & 0.59 & 1667 & 28 & 1610 & 25 & 4.04 & 2.3 & 0.295 & 1.9 & 0.8 \\
\hline FR-2-3.1 & --- & 0.0794 & -0.204 & 165 & 0.43 & 1223 & 20 & 1183 & 27 & 2.29 & 2.3 & 0.209 & 1.8 & 0.8 \\
\hline FR-2-4.1 & 0.000107 & 0.0574 & 0.243 & 205 & 0.64 & 432 & 7 & & & 0.53 & 3.5 & 0.069 & 1.7 & 0.5 \\
\hline FR-2-5.1 & 0.000107 & 0.0564 & 0.065 & 432 & 1.05 & 447 & 9 & & & 0.54 & 3.0 & 0.072 & 2.1 & 0.7 \\
\hline FR-2-6.1 & 0.000032 & 0.0999 & 0.007 & 166 & 0.44 & 1621 & 26 & 1615 & 19 & 3.92 & 2.1 & 0.286 & 1.8 & 0.9 \\
\hline FR-2-7.1 & --- & 0.0719 & -0.174 & 101 & 0.49 & 1021 & 32 & & & 1.70 & 3.8 & 0.172 & 3.4 & 0.9 \\
\hline FR-2-8.1 & 0.000039 & 0.0964 & -0.103 & 201 & 0.63 & 1570 & 24 & 1544 & 18 & 3.64 & 2.0 & 0.276 & 1.7 & 0.9 \\
\hline FR-2-9.1 & --- & 0.0579 & 0.127 & 346 & 0.35 & 488 & 8 & & 36 & 0.63 & 2.4 & 0.079 & 1.7 & 0.7 \\
\hline FR-2-10.1 & 0.000061 & 0.0992 & 0.175 & 140 & 0.56 & 1582 & 26 & 1594 & 22 & 3.77 & 2.2 & 0.278 & 1.9 & 0.8 \\
\hline FR-2-11.1 & 0.000078 & 0.0722 & 0.076 & 251 & 0.62 & 974 & 15 & & & 1.60 & 2.2 & 0.163 & 1.7 & 0.8 \\
\hline FR-2-12.1 & 0.000039 & 0.1138 & 0.291 & 117 & 0.16 & 1824 & 30 & 1853 & 32 & 5.11 & 2.6 & 0.327 & 1.9 & 0.7 \\
\hline FR-2-13.1 & 0.000096 & 0.0791 & 0.696 & 94 & 0.34 & 1026 & 19 & 1140 & 51 & 1.85 & 3.2 & 0.173 & 2.0 & 0.6 \\
\hline FR-2-14.1 & 0.000010 & 0.1848 & 0.290 & 146 & 1.09 & 2679 & 40 & 2695 & 10 & 13.12 & 1.9 & 0.515 & 1.8 & 0.9 \\
\hline FR-2-15.1 & 0.000154 & 0.0781 & -0.053 & 123 & 0.78 & 1158 & 20 & 1094 & 39 & 2.06 & 2.7 & 0.197 & 1.9 & 0.7 \\
\hline FR-2-16.1 & 0.000120 & 0.0854 & 0.848 & 810 & 0.61 & 1160 & 24 & 1285 & 13 & 2.27 & 2.3 & 0.197 & 2.2 & 1.0 \\
\hline FR-2-17.1 & 0.000066 & 0.0817 & 0.169 & 158 & 0.46 & 1206 & 20 & 1217 & 27 & 2.29 & 2.3 & 0.206 & 1.8 & 0.8 \\
\hline FR-2-18.1 & 0.000014 & 0.0894 & 0.395 & 239 & 0.42 & 1343 & 22 & 1408 & 22 & 2.85 & 2.1 & 0.232 & 1.8 & 0.8 \\
\hline FR-2-19.1 & 0.000073 & 0.1005 & -0.078 & 76 & 0.54 & 1642 & 30 & 1614 & 30 & 3.98 & 2.6 & 0.290 & 2.1 & 0.8 \\
\hline FR-2-20.1 & 0.000139 & 0.0805 & 0.420 & 75 & 0.24 & 1123 & 33 & 1161 & 46 & 2.06 & 4.0 & 0.190 & 3.2 & 0.8 \\
\hline FR-2-21.1 & .000027 & 881 & 0.207 & 111 & 0.39 & 1347 & 23 & 1375 & 26 & 2.81 & 2.3 & 0.232 & 1.9 & 0.8 \\
\hline FR-2-22.1 & 0.000049 & 0.0632 & -0.092 & 299 & 0.25 & 738 & 12 & & & 1.04 & 2.4 & 0.121 & 1.8 & 0.7 \\
\hline FR-2-23.1 & 0.000358 & 0.0713 & -0.344 & 41 & 0.70 & 1038 & 24 & & & 1.59 & 6.1 & 0.175 & 2.5 & 0.4 \\
\hline FR-2-24.1 & 0.000067 & 0.0582 & 0.219 & 164 & 0.52 & 471 & 8 & & & 0.60 & 3.5 & 0.076 & 1.8 & 0.5 \\
\hline FR-2-25.1 & 0.000023 & 0.0615 & 0.087 & 327 & 0.53 & 632 & 12 & & & 0.87 & 2.6 & 0.103 & 2.1 & 0.8 \\
\hline FR-2-26.1 & --- & 0757 & -0.183 & 113 & 0.85 & 1125 & 21 & 1087 & 33 & 1.99 & 2.7 & 0.191 & 2.1 & 0.8 \\
\hline FR-2-27.1 & --- & 0.0569 & 0.056 & 44 & 0.55 & 471 & 12 & & & 0.59 & 10.1 & 0.076 & 2.7 & 0.3 \\
\hline FR-2-28.1 & 0.000010 & 0.1108 & 0.049 & 468 & 0.25 & 1805 & 25 & 1810 & 10 & 4.93 & 1.7 & 0.323 & 1.6 & 0.9 \\
\hline FR-2-29.1 & 0.000088 & 0.0550 & -0.180 & 219 & 0.92 & 469 & 8 & & & 0.56 & 3.2 & 0.075 & 1.8 & 0.5 \\
\hline FR-2-30.1 & -0.000066 & 0.0715 & -0.328 & 70 & 1.15 & 1047 & 21 & & & 1.76 & 3.3 & 0.176 & 2.1 & 0.6 \\
\hline FR-2-31.1 & 0.000026 & 0.0559 & 0.008 & 456 & 0.86 & 445 & 7 & & & 0.55 & 2.3 & 0.071 & 1.6 & 0.7 \\
\hline FR-2-32.1 & 0.000060 & 0.0755 & -0.025 & 374 & 0.48 & 1085 & 17 & 1058 & 22 & 1.89 & 2.0 & 0.183 & 1.7 & 0.8 \\
\hline FR-2-33.1 & 0.000075 & 0.0618 & 0.271 & 103 & 0.72 & 589 & 11 & & & 0.80 & 3.7 & 0.096 & 1.9 & 0.5 \\
\hline FR-2-34.1 & 0.000018 & 0.0892 & -0.671 & 325 & 0.40 & 1519 & 23 & 1404 & 28 & 3.26 & 2.2 & 0.266 & 1.7 & 0.8 \\
\hline FR-2-35.1 & --- & 0.0560 & -0.041 & 252 & 0.70 & 467 & 11 & & & 0.58 & 3.1 & 0.075 & 2.4 & 0.8 \\
\hline FR-2-36.1 & 0.000349 & 0.0984 & -0.401 & 58 & 0.84 & 1644 & 33 & 1498 & 47 & 3.74 & 3.3 & 0.290 & 2.2 & 0.7 \\
\hline FR-2-37.1 & --- & 0.0771 & 0.540 & 10 & 1.81 & 1006 & 44 & 1123 & 112 & 1.80 & 7.3 & 0.169 & 4.7 & 0.6 \\
\hline FR-2-38.1 & --- & 0.0809 & -0.007 & 227 & 0.32 & 1220 & 19 & 1218 & 20 & 2.32 & 2.0 & 0.208 & 1.7 & 0.9 \\
\hline FR-2-39.1 & -0.000213 & 0.0751 & 0.544 & 23 & 1.23 & 954 & 27 & 1151 & 106 & 1.72 & 6.1 & 0.160 & 3.1 & 0.5 \\
\hline FR-2-40.1 & --- & 0.0735 & -0.014 & 72 & 0.42 & 1031 & 20 & 1028 & 41 & 1.76 & 2.9 & 0.173 & 2.1 & 0.7 \\
\hline FR-2-41.1 & 0.000027 & 0.0915 & 0.026 & 230 & 0.66 & 1453 & 22 & 1450 & 18 & 3.18 & 2.0 & 0.253 & 1.7 & 0.9 \\
\hline FR-2-42.1 & 0.000085 & 0.0602 & 0.215 & 91 & 0.53 & 548 & 11 & & & 0.72 & 4.0 & 0.089 & 2.0 & 0.5 \\
\hline FR-2-43.1 & 0.000074 & 0.0794 & 0.377 & 238 & 0.35 & 1104 & 17 & 1156 & 26 & 2.02 & 2.2 & 0.187 & 1.7 & 0.8 \\
\hline FR-2-44.1 & --- & 0.0786 & 0.460 & 37 & 0.73 & 1065 & 27 & 1161 & 58 & 1.95 & 4.0 & 0.180 & 2.7 & 0.7 \\
\hline FR-2-45.1 & 0.000009 & 0.0568 & 0.009 & 1109 & 0.38 & 481 & 7 & & & 0.60 & 1.8 & 0.077 & 1.6 & 0.9 \\
\hline FR-2-46.1 & --- & 0.0734 & 0.106 & 131 & 1.15 & 1002 & 18 & 1026 & 35 & 1.70 & 2.6 & 0.168 & 1.9 & 0.7 \\
\hline FR-2-47.1 & 0.000792 & 0.0639 & 1.029 & 317 & 0.27 & 433 & 8 & & & 0.50 & 5.4 & 0.069 & 2.0 & 0.4 \\
\hline
\end{tabular}


Appendix C: Continued.

\begin{tabular}{|c|c|c|c|c|c|c|c|c|c|c|c|c|c|c|}
\hline \multirow[b]{2}{*}{ sample $^{1}$} & \multirow[b]{2}{*}{$\begin{array}{l}\text { measured } \\
{ }^{204} \mathrm{~Pb} /{ }^{206} \mathrm{~Pb}\end{array}$} & \multirow[b]{2}{*}{$\begin{array}{l}\text { measured } \\
{ }^{207} \mathrm{~Pb} /{ }^{206} \mathrm{~Pb}\end{array}$} & \multirow[b]{2}{*}{$\begin{array}{l}\text { \%common } \\
{ }^{206} \mathrm{~Pb}\end{array}$} & \multirow[b]{2}{*}{$\begin{array}{c}\mathrm{U} \\
(\mathrm{ppm})\end{array}$} & \multirow[b]{2}{*}{$\mathrm{Th} / \mathrm{U}$} & \multicolumn{4}{|c|}{ Age (Ma) } & \multirow[b]{2}{*}{$\begin{array}{l}{ }^{207} \mathrm{~Pb} / \\
{ }^{235} \mathrm{U}^{5}\end{array}$} & \multirow[b]{2}{*}{$\begin{array}{l}\operatorname{err}^{4} \\
(\%)\end{array}$} & \multirow[b]{2}{*}{$\begin{array}{l}{ }^{206} \mathrm{~Pb} / \\
{ }^{238} \mathrm{U}^{5}\end{array}$} & \multirow[b]{2}{*}{$\begin{array}{l}\mathrm{err}^{4} \\
(\%)\end{array}$} & \multirow[b]{2}{*}{$\begin{array}{l}\text { err. } \\
\text { corr. }\end{array}$} \\
\hline & & & & & & $\begin{array}{l}{ }^{206} \mathrm{~Pb} / \\
{ }^{238} \mathrm{U}^{2}\end{array}$ & $\mathrm{err}^{4}$ & $\begin{array}{l}{ }^{207} \mathrm{~Pb} / \\
{ }^{206} \mathrm{~Pb}^{2,3}\end{array}$ & $\operatorname{err}^{4}$ & & & & & \\
\hline FR-2-48.1 & 0.000256 & 0.0602 & 0.065 & 81 & 0.53 & 590 & 12 & & & 0.75 & 6.3 & 0.096 & 2.2 & 0.4 \\
\hline FR-2-49.1 & 0.000120 & 0.0592 & 0.488 & 119 & 1.25 & 425 & 9 & & & 0.54 & 5.0 & 0.068 & 2.2 & 0.4 \\
\hline FR-2-50.1 & 0.000049 & 0.0550 & -0.159 & 224 & 0.64 & 464 & 12 & & & 0.56 & 3.7 & 0.075 & 2.7 & 0.7 \\
\hline FR-2-51.1 & --- & 0.0735 & -0.103 & 140 & 0.51 & 1050 & 19 & 1027 & 35 & 1.79 & 2.6 & 0.177 & 1.9 & 0.7 \\
\hline FR-2-52.1 & 0.000062 & 0.0601 & 0.356 & 184 & 0.53 & 500 & 9 & & & 0.66 & 3.3 & 0.081 & 1.8 & 0.5 \\
\hline FR-2-53.1 & --- & 0.1064 & -0.302 & 140 & 0.32 & 1779 & 29 & 1739 & 18 & 4.66 & 2.1 & 0.318 & 1.8 & 0.9 \\
\hline FR-2-54.1 & 0.000070 & 0.0583 & 0.080 & 364 & 0.50 & 516 & 8 & & & 0.66 & 2.4 & 0.083 & 1.6 & 0.7 \\
\hline FR-2-55.1 & --- & 0.0570 & -0.425 & 75 & 1.52 & 617 & 13 & & & 0.79 & 4.0 & 0.100 & 2.2 & 0.5 \\
\hline FR-2-56.1 & 0.000046 & 0.0903 & -0.008 & 123 & 0.45 & 1433 & 50 & 1419 & 25 & 3.08 & 4.1 & 0.249 & 3.9 & 0.9 \\
\hline FR-2-57.1 & 0.000037 & 0.0774 & -0.011 & 242 & 0.36 & 1134 & 18 & 1119 & 25 & 2.04 & 2.1 & 0.192 & 1.7 & 0.8 \\
\hline FR-2-58.1 & 0.000055 & 0.0956 & 0.127 & 102 & 0.76 & 1519 & 26 & 1525 & 26 & 3.47 & 2.4 & 0.266 & 1.9 & 0.8 \\
\hline FR-2-59.1 & 0.000023 & 0.0562 & -0.024 & 455 & 0.77 & 466 & 7 & & & 0.58 & 3.5 & 0.075 & 1.6 & 0.5 \\
\hline FR-2-60.1 & --- & 0.1150 & -0.431 & 62 & 0.78 & 1931 & 37 & 1880 & 25 & 5.54 & 2.6 & 0.349 & 2.2 & 0.8 \\
\hline FR-2-61.1 & 0.000041 & 0.0558 & -0.090 & 256 & 0.71 & 472 & 8 & & & 0.58 & 2.8 & 0.076 & 1.7 & 0.6 \\
\hline FR-2-62.1 & 0.000019 & 0.1123 & -0.413 & 129 & 1.87 & 1887 & 33 & 1833 & 19 & 5.25 & 2.3 & 0.340 & 2.0 & 0.9 \\
\hline FR-2-63.1 & 0.000021 & 0.0581 & -0.056 & 534 & 0.88 & 552 & 12 & & & 0.71 & 2.6 & 0.089 & 2.2 & 0.8 \\
\hline FR-2-64.1 & 0.000010 & 0.1016 & -0.282 & 904 & 1.90 & 1693 & 23 & 1651 & 10 & 4.20 & 1.7 & 0.300 & 1.6 & 0.9 \\
\hline FR-2-65.1 & --- & 0.0785 & -0.032 & 129 & 0.81 & 1167 & 20 & 1161 & 29 & 2.15 & 2.4 & 0.198 & 1.9 & 0.8 \\
\hline FR-2-66.1 & -0.000024 & 0.0813 & -0.072 & 136 & 0.53 & 1243 & 22 & 1237 & 48 & 2.39 & 3.1 & 0.213 & 1.9 & 0.6 \\
\hline FR-2-67.1 & 0.000061 & 0.0810 & 0.038 & 63 & 0.43 & 1212 & 24 & 1200 & 45 & 2.28 & 3.2 & 0.207 & 2.2 & 0.7 \\
\hline FR-2-68.1 & --- & 0.1954 & 3.119 & 67 & 0.74 & 2601 & 49 & 2788 & 18 & 13.39 & 2.5 & 0.497 & 2.3 & 0.9 \\
\hline FR-2-69.1 & 0.000090 & 0.0776 & 0.156 & 252 & 0.61 & 1103 & 132 & 1104 & 120 & 1.96 & 14.4 & 0.187 & 13.1 & 0.9 \\
\hline FR-2-70.1 & 0.000141 & 0.0768 & 0.003 & 40 & 0.72 & 1113 & 27 & 1063 & 84 & 1.94 & 5.0 & 0.189 & 2.6 & 0.5 \\
\hline
\end{tabular}

Appleton Ridge Formation (AR) : AR-1 Appleton Ridge type locality. Searsmont quadrangle, UTM Location $478363 \mathrm{E} / 4903810 \mathrm{~N}$

\begin{tabular}{|c|c|c|c|c|c|c|c|c|c|c|c|c|c|c|}
\hline MEWFT-2-1.1 & 0.000042 & 0.0719 & 0.071 & 105 & 0.41 & 997 & 11 & & & 1.65 & 2.2 & 0.167 & 1.2 & 0.6 \\
\hline MEWFT-2-2.1 & -0.000012 & 0.0866 & -0.019 & 267 & 0.41 & 1334 & 14 & 1354 & 13 & 2.75 & 1.3 & 0.230 & 1.1 & 0.9 \\
\hline MEWFT-2-3.1 & -0.000015 & 0.0742 & -0.026 & 292 & 0.18 & 1008 & 12 & 1051 & 17 & 1.74 & 1.6 & 0.169 & 1.3 & 0.8 \\
\hline MEWFT-2-4.1 & -0.000040 & 0.0721 & -0.069 & 110 & 0.51 & 995 & 11 & 1005 & 62 & 1.67 & 3.3 & 0.167 & 1.2 & 0.4 \\
\hline MEWFT-2-5.1 & 0.000154 & 0.1039 & 0.245 & 589 & 0.46 & 1453 & 17 & 1656 & 13 & 3.55 & 1.5 & 0.253 & 1.3 & 0.9 \\
\hline MEWFT-2-6.1 & 0.000073 & 0.0836 & 0.122 & 122 & 0.4 & 1194 & 20 & 1258 & 31 & 2.32 & 2.4 & 0.203 & 1.8 & 0.7 \\
\hline MEWFT-2-7.1 & 0.001025 & 0.0791 & 1.795 & 49 & 0.61 & 1046 & 16 & & & 1.56 & 11.0 & 0.176 & 1.6 & 0.1 \\
\hline MEWFT-2-8.1 & 0.000170 & 0.0730 & 0.292 & 51 & 0.45 & 1032 & 13 & & & 1.69 & 4.5 & 0.174 & 1.4 & 0.3 \\
\hline MEWFT-2-9.1 & 0.000032 & 0.0856 & 0.053 & 155 & 0.75 & 1320 & 14 & 1318 & 21 & 2.67 & 1.6 & 0.227 & 1.2 & 0.7 \\
\hline MEWFT-2-10.1 & 0.000902 & 0.0716 & 1.609 & 25 & 0.98 & 973 & 19 & & & 1.31 & 17.7 & 0.163 & 2.1 & 0.1 \\
\hline MEWFT-2-11.1 & 0.000109 & 0.0571 & 0.196 & 133 & 0.79 & 474 & 9 & & & 0.58 & 5.3 & 0.076 & 1.9 & 0.4 \\
\hline MEWFT-2-12.1 & 0.000254 & 0.0742 & 0.437 & 36 & 0.89 & 956 & 21 & & & 1.55 & 6.7 & 0.160 & 2.4 & 0.4 \\
\hline MEWFT-2-13.1 & 0.000113 & 0.1219 & 0.173 & 183 & 0.34 & 1975 & 20 & 1961 & 15 & 5.95 & 1.4 & 0.358 & 1.2 & 0.8 \\
\hline MEWFT-2-14.1 & 0.000064 & 0.0824 & 0.107 & 227 & 0.47 & 1158 & 17 & 1232 & 31 & 2.21 & 2.3 & 0.197 & 1.6 & 0.7 \\
\hline MEWFT-2-15.1 & 0.000259 & 0.0593 & 0.467 & 166 & 0.48 & 461 & 7 & & & 0.57 & 6.2 & 0.074 & 1.6 & 0.3 \\
\hline MEWFT-2-16.1 & 0.000150 & 0.0783 & 0.253 & 58 & 0.48 & 996 & 12 & 1098 & 87 & 1.75 & 4.6 & 0.167 & 1.4 & 0.3 \\
\hline MEWFT-2-17.1 & 0.000229 & 0.0824 & 0.384 & 111 & 0.32 & 1188 & 13 & 1176 & 72 & 2.21 & 3.8 & 0.202 & 1.2 & 0.3 \\
\hline MEWFT-2-18.1 & 0.000225 & 0.0765 & 0.384 & 87 & 0.28 & 1003 & 22 & 1020 & 72 & 1.70 & 4.3 & 0.168 & 2.4 & 0.6 \\
\hline MEWFT-2-19.1 & --- & 0.0733 & 0 & 127 & 0.55 & 998 & 11 & 1021 & 22 & 1.69 & 1.6 & 0.167 & 1.2 & 0.7 \\
\hline MEWFT-2-20.1 & 0.000018 & 0.0705 & 0.030 & 742 & 0.34 & 969 & 12 & & & 1.57 & 1.5 & 0.162 & 1.4 & 0.9 \\
\hline MEWFT-2-21.1 & 0.000181 & 0.0745 & 0.310 & 45 & 0.34 & 999 & 13 & & & 1.66 & 4.7 & 0.168 & 1.4 & 0.3 \\
\hline MEWFT-2-22.1 & 0.000019 & 0.0766 & 0.033 & 1506 & 0.02 & 912 & 9 & 1103 & 8 & 1.60 & 1.1 & 0.152 & 1.1 & 0.9 \\
\hline MEWFT-2-23.1 & 0.000478 & 0.0845 & 0.804 & 33 & 0.46 & 1228 & 18 & 1138 & 136 & 2.25 & 7.1 & 0.210 & 1.6 & 0.2 \\
\hline MEWFT-2-24.1 & 0.000120 & 0.0575 & 0.216 & 552 & 0.68 & 466 & 5 & & & 0.58 & 2.4 & 0.075 & 1.1 & 0.5 \\
\hline
\end{tabular}


Appendix C: Continued.

\begin{tabular}{|c|c|c|c|c|c|c|c|c|c|c|c|c|c|c|}
\hline \multirow[b]{2}{*}{ sample ${ }^{1}$} & \multirow[b]{2}{*}{$\begin{array}{l}\text { measured } \\
{ }^{204} \mathrm{~Pb} /{ }^{206} \mathrm{~Pb}\end{array}$} & \multirow[b]{2}{*}{$\begin{array}{l}\text { measured } \\
{ }^{207} \mathrm{~Pb} /{ }^{206} \mathrm{~Pb}\end{array}$} & \multirow[b]{2}{*}{$\begin{array}{l}\text { \%common } \\
{ }^{206} \mathrm{~Pb}\end{array}$} & \multirow[b]{2}{*}{$\begin{array}{c}\mathrm{U} \\
(\mathrm{ppm})\end{array}$} & \multirow[b]{2}{*}{$\mathrm{Th} / \mathrm{U}$} & \multicolumn{4}{|c|}{ Age (Ma) } & \multirow[b]{2}{*}{$\begin{array}{l}{ }^{207} \mathrm{~Pb} / \\
{ }^{235} \mathrm{U}^{5}\end{array}$} & \multirow[b]{2}{*}{$\begin{array}{l}\operatorname{err}^{4} \\
(\%)\end{array}$} & \multirow[b]{2}{*}{$\begin{array}{l}{ }^{206} \mathrm{~Pb} / \\
{ }^{238} \mathrm{U}^{5}\end{array}$} & \multirow[b]{2}{*}{$\begin{array}{l}\mathrm{err}^{4} \\
(\%)\end{array}$} & \multirow[b]{2}{*}{$\begin{array}{l}\text { err. } \\
\text { corr. }\end{array}$} \\
\hline & & & & & & $\begin{array}{l}{ }^{206} \mathrm{~Pb} / \\
{ }^{238} \mathrm{U}^{2}\end{array}$ & $\mathrm{err}^{4}$ & $\begin{array}{l}{ }^{207} \mathrm{~Pb} / \\
{ }^{206} \mathrm{~Pb}^{2,3}\end{array}$ & $\operatorname{err}^{4}$ & & & & & \\
\hline MEWFT-2-25.1 & 0.000037 & 0.0762 & 0.063 & 212 & 0.22 & 1074 & 11 & 1087 & 23 & 1.89 & 1.6 & 0.181 & 1.1 & 0.7 \\
\hline MEWFT-2-26.1 & -0.000046 & 0.0608 & -0.081 & 109 & 1 & 453 & 5 & & & 0.62 & 3.3 & 0.073 & 1.2 & 0.4 \\
\hline MEWFT-2-27.1 & -0.000023 & 0.0583 & -0.041 & 200 & 0.62 & 471 & 6 & & & 0.61 & 2.3 & 0.076 & 1.3 & 0.6 \\
\hline MEWFT-2-28.1 & 0.000042 & 0.1031 & 0.067 & 56 & 0.83 & 1663 & 19 & 1670 & 26 & 4.16 & 1.9 & 0.294 & 1.3 & 0.7 \\
\hline MEWFT-2-29.1 & 0.000034 & 0.0853 & 0.056 & 664 & 0.2 & 1260 & 14 & 1309 & 10 & 2.52 & 1.3 & 0.216 & 1.2 & 0.9 \\
\hline MEWFT-2-30.1 & 0.000063 & 0.0566 & 0.114 & 237 & 0.58 & 467 & 5 & & & 0.58 & 2.8 & 0.075 & 1.2 & 0.4 \\
\hline MEWFT-2-31.1 & 0.000098 & 0.0735 & 0.167 & 62 & 0.45 & 1046 & 13 & & & 1.75 & 3.2 & 0.176 & 1.3 & 0.4 \\
\hline MEWFT-2-32.1 & 0 & 0.0582 & 0 & 169 & 0.79 & 474 & 5 & & & 0.61 & 2.0 & 0.076 & 1.2 & 0.6 \\
\hline MEWFT-2-33.1 & 0.000247 & 0.0739 & 0.424 & 81 & 0.45 & 980 & 21 & & & 1.59 & 4.7 & 0.164 & 2.3 & 0.5 \\
\hline MEWFT-2-34.1 & --- & 0.0573 & 0 & 450 & 0.43 & 463 & 7 & & & 0.59 & 2.0 & 0.074 & 1.7 & 0.8 \\
\hline MEWFT-2-35.1 & 0.000138 & 0702 & 0.239 & 49 & 0.35 & 978 & 13 & & & 1.54 & 4.5 & 0.164 & 1.4 & 0.3 \\
\hline MEWFT-2-36.1 & -0.000036 & 0733 & -0.062 & 169 & 0.44 & 1027 & 11 & 1036 & 26 & 1.76 & 1.7 & 0.173 & 1.2 & 0.7 \\
\hline MEWFT-2-37.1 & 0.000040 & 0.0935 & 0.065 & 282 & 0.18 & 1449 & 15 & 1487 & 14 & 3.23 & 1.4 & 0.252 & 1.1 & 0.8 \\
\hline MEWFT-2-38.1 & -0.000010 & 0.0970 & -0.016 & 395 & 0.41 & 1544 & 23 & 1570 & 9 & 3.63 & 1.7 & 0.271 & 1.7 & 1.0 \\
\hline MEWFT-2-39.1 & 0.000026 & 0.0996 & 0.042 & 96 & 0.43 & 1632 & 18 & 1609 & 19 & 3.94 & 1.6 & 0.288 & 1.2 & 0.8 \\
\hline MEWFT-2-41.1 & .000042 & 943 & 0.068 & 172 & 0.65 & 1461 & 18 & 1502 & 18 & 3.29 & 1.7 & 0.254 & 1.4 & 0.8 \\
\hline MEWFT-2-42.1 & 0.000807 & 0576 & 1.508 & 0 & 2.56 & 472 & 7 & & & 0.48 & 16.2 & 0.076 & 1.5 & 0.1 \\
\hline MEWFT-2-43.1 & 0.000004 & 0.0599 & 0.007 & 858 & 0.57 & 605 & 7 & & & 0.81 & 1.4 & 0.098 & 1.2 & 0.9 \\
\hline MEWFT-2-44.1 & -0.000080 & 0.0560 & -0.144 & 182 & 0.74 & 467 & 5 & & & 0.59 & 3.4 & 0.075 & 1.2 & 0.4 \\
\hline MEWFT-2-45.1 & 0.001180 & 0.0626 & 2.206 & 24 & 0.5 & 470 & 12 & & & 0.47 & 36.6 & 0.076 & 2.7 & 0.1 \\
\hline MEWFT-2-46.1 & 0.000137 & 0743 & 0.233 & 112 & 0.45 & 1060 & 12 & & & 1.78 & 2.7 & 0.179 & 1.2 & 0.4 \\
\hline MEWFT-2-47.1 & -0.000032 & 0569 & -0.057 & & 0.68 & 473 & 5 & & & 0.60 & 2.1 & 0.076 & 1.1 & 0.6 \\
\hline MEWFT-2-48.1 & 0.000144 & 0842 & 0.239 & 177 & 0.25 & 1251 & 16 & 1249 & 32 & 2.43 & 2.1 & 0.214 & 1.4 & 0.6 \\
\hline MEWFT-2-49.1 & -0.000009 & 0.0865 & -0.014 & 182 & 0.41 & 1338 & 14 & 1352 & 15 & 2.76 & 1.4 & 0.231 & 1.2 & 0.8 \\
\hline MEWFT-2-50.1 & 0.000089 & 0.0727 & 0.153 & 92 & 0.47 & 1018 & 16 & & & 1.68 & 2.9 & 0.171 & 1.7 & 0.6 \\
\hline MEWFT-2-51.1 & 0.000028 & 0.0769 & 0.047 & 681 & 0.23 & 1023 & 12 & 1108 & 12 & 1.81 & 1.4 & 0.172 & 1.3 & 0.9 \\
\hline MEWFT-2-52.1 & 0.000272 & 0.0802 & 0.459 & 53 & 0.78 & 1168 & 32 & 1103 & 86 & 2.09 & 5.3 & 0.199 & 3.0 & 0.6 \\
\hline MEWFT-2-53.1 & 0.000038 & 0.0640 & 0.067 & 345 & 0.16 & 635 & 13 & & & 0.91 & 2.5 & 0.103 & 2.1 & 0.9 \\
\hline MEWFT-2-54.1 & 0.000249 & 0.0730 & 0.429 & 85 & 0.62 & 1017 & 12 & & & 1.64 & 4.1 & 0.171 & 1.3 & 0.3 \\
\hline MEWFT-2-55.1 & 0.000355 & 0.0937 & 0.580 & 73 & 0.77 & 1441 & 25 & 1399 & 61 & 3.07 & 3.7 & 0.250 & 2.0 & 0.5 \\
\hline MEWFT-2-56.1 & -0.000007 & 0.0987 & -0.012 & 657 & 0.26 & 1250 & 21 & 1601 & 7 & 2.92 & 1.8 & 0.214 & 1.8 & 1.0 \\
\hline MEWFT-2-57.1 & 0.000193 & 0.1085 & 0.303 & 272 & 0.69 & 1679 & 17 & 1728 & 18 & 4.34 & 1.5 & 0.298 & 1.1 & 0.8 \\
\hline MEWFT-2-58.1 & -0.000157 & 0.0628 & -0.274 & 90 & 0.76 & 465 & 12 & & & 0.67 & 5.6 & 0.075 & 2.7 & 0.5 \\
\hline MEWFT-2-59.1 & -0.000013 & 0.0576 & -0.023 & 364 & 0.51 & 466 & 5 & & & 0.60 & 1.7 & 0.075 & 1.1 & 0.7 \\
\hline MEWFT-2-60.1 & 0.000510 & 0.0949 & 0.835 & 353 & 0.43 & 1307 & 16 & 1377 & 34 & 2.72 & 2.2 & 0.225 & 1.3 & 0.6 \\
\hline
\end{tabular}

CENTRAL MAINE/AROOSTOOK-MATAPEDIA BASIN

Mayflower Hill Formation (MH) :MH-1 Lower part of formation near contact with Smyrna Mills Fm (Waterville Fm equivalent), Rollins Mountain. East Winn quadrangle, UTM Location 0548340E/5029038N

\begin{tabular}{|c|c|c|c|c|c|c|c|c|c|c|c|c|c|c|}
\hline MH1-12-1.1 & 0.000064 & 0.0555 & 0.117 & 311 & 0.54 & 439 & 6 & & & 0.5 & 2.3 & 0.071 & 1.3 & 0.6 \\
\hline MH1-12-2.1 & 0.000123 & 0.0576 & 0.226 & 1197 & 0.61 & 466 & 3 & & & 0.6 & 1.3 & 0.075 & 0.7 & 0.5 \\
\hline MH1-12-3.1 & 0.000040 & 0.0562 & 0.072 & 800 & 1.00 & 435 & 4 & & & 0.5 & 1.4 & 0.070 & 1.0 & 0.7 \\
\hline MH1-12-4.1 & 0.000032 & 0.0591 & 0.059 & 504 & 0.77 & 443 & 5 & & & 0.6 & 1.6 & 0.071 & 1.1 & 0.7 \\
\hline MH1-12-5.1 & 0.000004 & 0.0561 & 0.008 & 3061 & 0.77 & 446 & 7 & & & 0.6 & 1.8 & 0.072 & 1.7 & 1.0 \\
\hline MH1-12-6.1 & 0.000007 & 0.0883 & 0.014 & 1377 & 0.45 & 1365 & 12 & 1387 & 7 & 2.9 & 1.0 & 0.236 & 1.0 & 0.9 \\
\hline MH1-12-7.1 & --- & 0.0574 & 0 & 869 & 1.23 & 441 & 6 & & & 0.6 & 1.7 & 0.071 & 1.4 & 0.8 \\
\hline MH1-12-8.1 & 0.000013 & 0.0869 & 0.025 & 188 & 0.49 & 1325 & 12 & 1353 & 19 & 2.7 & 1.4 & 0.228 & 1.0 & 0.7 \\
\hline MH1-12-9.1 & --- & 0.0548 & 0 & 320 & 0.75 & 423 & 7 & & & 0.5 & 2.4 & 0.068 & 1.7 & 0.7 \\
\hline MH1-12-10.1 & 0.000009 & 0.0572 & 0.017 & 927 & 0.88 & 445 & 6 & & & 0.6 & 1.9 & 0.071 & 1.4 & 0.8 \\
\hline MH1-12-11.1 & 0.000033 & 0.0973 & 0.060 & 1180 & 0.08 & 1489 & 12 & 1563 & 6 & 3.5 & 0.9 & 0.260 & 0.9 & 0.9 \\
\hline
\end{tabular}


Appendix C: Continued.

\begin{tabular}{|c|c|c|c|c|c|c|c|c|c|c|c|c|c|c|}
\hline \multirow[b]{2}{*}{ sample $^{1}$} & \multirow[b]{2}{*}{$\begin{array}{l}\text { measured } \\
{ }^{204} \mathrm{~Pb} /{ }^{206} \mathrm{~Pb}\end{array}$} & \multirow[b]{2}{*}{$\begin{array}{c}\text { measured } \\
{ }^{207} \mathrm{~Pb} /{ }^{206} \mathrm{~Pb}\end{array}$} & \multirow[b]{2}{*}{$\begin{array}{l}\text { \%common } \\
{ }^{206} \mathrm{~Pb}\end{array}$} & \multirow[b]{2}{*}{$\begin{array}{c}\mathrm{U} \\
(\mathrm{ppm})\end{array}$} & \multirow[b]{2}{*}{$\mathrm{Th} / \mathrm{U}$} & \multicolumn{4}{|c|}{ Age (Ma) } & \multirow[b]{2}{*}{$\begin{array}{l}{ }^{207} \mathrm{~Pb} / \\
{ }^{235} \mathrm{U}^{5}\end{array}$} & \multirow[b]{2}{*}{$\begin{array}{l}\mathrm{err}^{4} \\
(\%)\end{array}$} & \multirow[b]{2}{*}{$\begin{array}{l}{ }^{206} \mathrm{~Pb} / \\
{ }^{238} \mathrm{U}^{5}\end{array}$} & \multirow[b]{2}{*}{$\begin{array}{l}\mathrm{err}^{4} \\
(\%)\end{array}$} & \multirow[b]{2}{*}{$\begin{array}{l}\text { err. } \\
\text { corr }\end{array}$} \\
\hline & & & & & & $\begin{array}{l}{ }^{206} \mathrm{~Pb} / \\
{ }^{238} \mathrm{U}^{2}\end{array}$ & $\mathrm{err}^{4}$ & $\begin{array}{c}{ }^{207} \mathrm{~Pb} / \\
{ }^{206} \mathrm{~Pb}^{2,3}\end{array}$ & $\mathrm{err}^{4}$ & & & & & \\
\hline MH1-12-12.1 & --- & 0.1075 & 0 & 895 & 0.16 & 1783 & 18 & 1758 & 6 & 4.7 & 1.2 & 0.319 & 1.2 & 1.0 \\
\hline MH1-12-13.1 & 0.000042 & 0.0572 & 0.077 & 658 & 0.74 & 432 & 5 & & & 0.5 & 1.8 & 0.069 & 1.2 & 0.7 \\
\hline MH1-12-14.1 & 0.000029 & 0.0903 & 0.053 & 182 & 0.35 & 1388 & 12 & 1424 & 20 & 3.0 & 1.4 & 0.240 & 1.0 & 0.7 \\
\hline MH1-12-15.1 & 0.000210 & 0.0997 & 0.384 & 253 & 0.49 & 1558 & 18 & 1563 & 18 & 3.6 & 1.6 & 0.273 & 1.3 & 0.8 \\
\hline MH1-12-16.1 & 0.000139 & 0.0724 & 0.254 & 768 & 0.10 & 775 & 13 & & & 1.2 & 1.9 & 0.128 & 1.7 & 0.9 \\
\hline MH1-12-17.1* & 0.000078 & 0.1334 & 0.142 & 873 & 0.39 & 1533 & 10 & 2129 & 7 & 4.9 & 0.8 & 0.268 & 0.7 & 0.9 \\
\hline MH1-12-18.1 & --- & 0.0999 & 0 & 381 & 0.69 & 1607 & 16 & 1622 & 10 & 3.9 & 1.3 & 0.283 & 1.2 & 0.9 \\
\hline MH1-12-19.1 & 0.000006 & 0.1077 & 0.011 & 609 & 0.30 & 1711 & 15 & 1760 & 8 & 4.5 & 1.1 & 0.304 & 1.0 & 0.9 \\
\hline MH1-12-20.1 & 0.000425 & 0.0603 & 0.778 & 346 & 1.16 & 434 & 4 & & & 0.5 & 3.8 & 0.070 & 0.9 & 0.2 \\
\hline MH1-12-21.1 & 0.000018 & 0.0859 & 0.033 & 473 & 0.80 & 1342 & 17 & 1330 & 11 & 2.7 & 1.5 & 0.231 & 1.4 & 0.9 \\
\hline MH1-12-22.1 & 0.000020 & 0.0941 & 0.036 & 1192 & 0.65 & 1533 & 15 & 1505 & 6 & 3.5 & 1.2 & 0.268 & 1.1 & 1.0 \\
\hline MH1-12-23.1 & -0.000019 & 0.0558 & -0.035 & 432 & 0.83 & 425 & 3 & & & 0.5 & 1.7 & 0.068 & 0.8 & 0.5 \\
\hline MH1-12-24.1 & 0.000008 & 0.1164 & 0.014 & 218 & 0.92 & 1825 & 16 & 1899 & 22 & 5.2 & 1.5 & 0.327 & 1.0 & 0.6 \\
\hline MH1-12-25.1 & 0.000067 & 0.0740 & 0.122 & 224 & 0.63 & 1026 & 13 & 1016 & 24 & 1.7 & 1.8 & 0.173 & 1.3 & 0.7 \\
\hline MH1-12-26.1 & 0.000011 & 0.1006 & 0.020 & 567 & 1.07 & 1597 & 14 & 1632 & 9 & 3.9 & 1.1 & 0.281 & 1.0 & 0.9 \\
\hline MH1-12-27.1 & --- & 0.0731 & 0 & 257 & 0.39 & 1004 & 7 & 1017 & 19 & 1.7 & 1.2 & 0.169 & 0.8 & 0.7 \\
\hline MH1-12-28.1 & 0.000595 & 0.0845 & 1.090 & 110 & 0.28 & 1067 & 11 & 1096 & 59 & 1.9 & 3.2 & 0.180 & 1.1 & 0.4 \\
\hline MH1-12-29.1 & 0.000011 & 0.0941 & 0.020 & 865 & 0.53 & 1481 & 18 & 1507 & 7 & 3.3 & 1.4 & 0.258 & 1.3 & 1.0 \\
\hline MH1-12-30.1 & 0.000013 & 0.1001 & 0.024 & 443 & 0.42 & 1630 & 11 & 1622 & 10 & 4.0 & 0.9 & 0.288 & 0.8 & 0.8 \\
\hline MH1-12-31.1 & 0.000004 & 0.0811 & 0.007 & 635 & 0.34 & 1172 & 8 & 1223 & 51 & 2.2 & 2.7 & 0.199 & 0.7 & 0.3 \\
\hline MH1-12-32.1 & --- & 0.0734 & 0 & 134 & 1.45 & 1026 & 11 & 1025 & 54 & 1.7 & 2.9 & 0.173 & 1.2 & 0.4 \\
\hline MH1-12-33.1 & 0.000022 & 0.0970 & 0.040 & 378 & 0.93 & 1492 & 28 & 1561 & 12 & 3.5 & 2.2 & 0.260 & 2.1 & 1.0 \\
\hline MH1-12-34.1 & 0.000051 & 0.1006 & 0.093 & 251 & 0.94 & 1619 & 13 & 1623 & 15 & 3.9 & 1.2 & 0.285 & 0.9 & 0.8 \\
\hline MH1-12-35.1 & .000364 & & 665 & 164 & 0.83 & 464 & 4 & & & 0.5 & 4.6 & 0.075 & 1.0 & 0.2 \\
\hline MH1-12-36.1 & 0.000005 & 0.1097 & 0.009 & 667 & 0.23 & 1764 & 11 & 1793 & 13 & 4.8 & 1.0 & 0.315 & 0.7 & 0.7 \\
\hline MH1-12-37.1 & -0.000006 & 0.0862 & -0.011 & 408 & 0.63 & 1320 & 25 & 1345 & 12 & 2.7 & 2.2 & 0.227 & 2.1 & 1.0 \\
\hline MH1-12-38.1 & 0.000109 & 0.0539 & 0.200 & 257 & 0.73 & 437 & 4 & & & 0.5 & 2.8 & 0.070 & 0.9 & 0.3 \\
\hline MH1-12-39.1 & 0.000005 & 0.1078 & 0.008 & 1000 & 0.67 & 1734 & 23 & 1761 & 5 & 4.6 & 1.5 & 0.309 & 1.5 & 1.0 \\
\hline MH1-12-40.1 & 0.000023 & 1090 & .042 & & 0.35 & 1601 & 23 & 1778 & 31 & 4.2 & 2.3 & 0.282 & 1.6 & 0.7 \\
\hline MH1-12-41.1 & 0.000043 & 0.0821 & 0.078 & 1072 & 0.03 & 1024 & 21 & 1234 & 37 & 1.9 & 2.9 & 0.172 & 2.2 & 0.8 \\
\hline MH1-12-42.1 & 0.000008 & 0.1018 & 0.015 & 204 & 0.55 & 1618 & 21 & 1655 & 27 & 4.0 & 2.1 & 0.285 & 1.5 & 0.7 \\
\hline MH1-12-43.1 & -0.000045 & 0.0878 & -0.082 & 57 & 0.88 & 1316 & 17 & 1391 & 36 & 2.8 & 2.4 & 0.226 & 1.4 & 0.6 \\
\hline MH1-12-44.1 & 0.000027 & 0.0868 & 0.050 & 385 & 0.51 & 1350 & 19 & 1348 & 14 & 2.8 & 1.8 & 0.233 & 1.6 & 0.9 \\
\hline MH1-12-45.1 & 0.000005 & 1865 & .010 & 04 & 0.39 & 2702 & 20 & 2711 & 7 & 13.4 & 1.0 & 0.521 & 0.9 & 0.9 \\
\hline MH1-12-46.1 & 0.000046 & 0.0845 & 0.084 & 1086 & 0.39 & 1225 & 23 & 1290 & 10 & 2.4 & 2.1 & 0.209 & 2.1 & 1.0 \\
\hline MH1-12-47.1 & 0.000007 & 0.0999 & 0.012 & 279 & 0.93 & 1622 & 12 & 1620 & 12 & 3.9 & 1.0 & 0.286 & 0.8 & 0.8 \\
\hline MH1-12-48.1 & -0.000021 & 0.0875 & -0.038 & 203 & 0.38 & 1419 & 11 & 1378 & 17 & 3.0 & 1.3 & 0.246 & 0.9 & 0.7 \\
\hline MH1-12-49.1 & 0.000010 & 0.0931 & 0.019 & 678 & 0.39 & 1437 & 10 & 1486 & 9 & 3.2 & 0.9 & 0.250 & 0.7 & 0.8 \\
\hline MH1-12-50.1 & --- & 0.0935 & 0 & 319 & 0.95 & 1544 & 11 & 1499 & 13 & 3.5 & 1.1 & 0.271 & 0.8 & 0.8 \\
\hline MH1-12-51.1 & 0.000012 & 0.0944 & 0.022 & 319 & 0.43 & 1464 & 23 & 1513 & 25 & 3.3 & 2.2 & 0.255 & 1.7 & 0.8 \\
\hline MH1-12-52.1 & 0.000025 & 0.0747 & 0.047 & 280 & 0.29 & 997 & 14 & 1050 & 22 & 1.7 & 1.8 & 0.167 & 1.5 & 0.8 \\
\hline MH1-12-53.1 & 0.000028 & 0.0698 & 0.051 & 586 & 0.29 & 621 & 4 & & & 1.0 & 1.2 & 0.101 & 0.8 & 0.6 \\
\hline MH1-12-54.1 & --- & 0.0760 & 0 & 1198 & 0.04 & 1087 & 13 & 1094 & 8 & 1.9 & 1.4 & 0.184 & 1.3 & 1.0 \\
\hline MH1-12-55.1 & --- & 0.0676 & 0 & 370 & 0.24 & 737 & 8 & & & 1.1 & 1.5 & 0.121 & 1.1 & 0.8 \\
\hline MH1-12-56.1 & --- & 0.1251 & 0 & 488 & 0.62 & 1983 & 29 & 2030 & 7 & 6.2 & 1.7 & 0.360 & 1.7 & 1.0 \\
\hline MH1-12-57.1 & 0.000007 & 0.1018 & 0.013 & 301 & 1.03 & 1661 & 12 & 1655 & 12 & 4.1 & 1.1 & 0.294 & 0.8 & 0.8 \\
\hline MH1-12-58.1 & 0.000043 & 0.0739 & 0.079 & 149 & 0.35 & 1020 & 19 & 1022 & 30 & 1.7 & 2.5 & 0.171 & 2.0 & 0.8 \\
\hline MH1-12-59.1 & 0.000263 & 0.0587 & 0.482 & 777 & 0.67 & 465 & 7 & & & 0.6 & 2.4 & 0.075 & 1.6 & 0.7 \\
\hline MH1-12-60.1 & 0.000020 & 0.0808 & 0.037 & 274 & 0.25 & 1200 & 10 & 1208 & 18 & 2.3 & 1.3 & 0.205 & 0.9 & 0.7 \\
\hline MH1-12-61.1 & 0.000020 & 0.0915 & 0.037 & 198 & 0.48 & 1525 & 14 & 1451 & 16 & 3.4 & 1.3 & 0.267 & 1.0 & 0.8 \\
\hline
\end{tabular}


Appendix C: Continued.

\begin{tabular}{|c|c|c|c|c|c|c|c|c|c|c|c|c|c|c|}
\hline \multirow[b]{2}{*}{ sample $^{1}$} & \multirow[b]{2}{*}{$\begin{array}{c}\text { measured } \\
{ }^{204} \mathrm{~Pb} /{ }^{206} \mathrm{~Pb}\end{array}$} & \multirow[b]{2}{*}{$\begin{array}{l}\text { measured } \\
{ }^{207} \mathrm{~Pb} /{ }^{206} \mathrm{~Pb}\end{array}$} & \multirow[b]{2}{*}{$\begin{array}{l}\text { \%common } \\
{ }^{206} \mathrm{~Pb}\end{array}$} & \multirow[b]{2}{*}{$\begin{array}{c}\mathrm{U} \\
(\mathrm{ppm})\end{array}$} & \multirow[b]{2}{*}{$\mathrm{Th} / \mathrm{U}$} & \multicolumn{4}{|c|}{ Age (Ma) } & \multirow[b]{2}{*}{$\begin{array}{l}{ }^{207} \mathrm{~Pb} / \\
{ }^{235} \mathrm{U}^{5}\end{array}$} & \multirow[b]{2}{*}{$\begin{array}{l}\text { err }^{4} \\
(\%)\end{array}$} & \multirow[b]{2}{*}{$\begin{array}{l}{ }^{206} \mathrm{~Pb} / \\
{ }^{238} \mathrm{U}^{5}\end{array}$} & \multirow[b]{2}{*}{$\begin{array}{l}\text { err }^{4} \\
(\%)\end{array}$} & \multirow[b]{2}{*}{$\begin{array}{l}\text { err. } \\
\text { corr. }\end{array}$} \\
\hline & & & & & & $\begin{array}{l}{ }^{206} \mathrm{~Pb} / \\
{ }^{238} \mathrm{U}^{2}\end{array}$ & $\mathrm{err}^{4}$ & $\begin{array}{l}{ }^{207} \mathrm{~Pb} / \\
{ }^{206} \mathrm{~Pb}^{2,3}\end{array}$ & $\operatorname{err}^{4}$ & & & & & \\
\hline MH1-12-62.1 & 0.000045 & 0.0724 & 0.082 & 438 & 0.74 & 1020 & 13 & & & 1.7 & 1.6 & 0.171 & 1.4 & 0.8 \\
\hline MH1-12-63.1 & 0.000027 & 0.0578 & 0.049 & 892 & 0.73 & 472 & 3 & & & 0.6 & 1.3 & 0.076 & 0.7 & 0.6 \\
\hline MH1-12-64.1 & 0.000031 & 0.0936 & 0.057 & 652 & 0.18 & 1543 & 24 & 1491 & 10 & 3.5 & 1.8 & 0.270 & 1.8 & 1.0 \\
\hline MH1-12-65.1 & --- & 0.0552 & 0 & 735 & 0.34 & 449 & 5 & & & 0.5 & 1.4 & 0.072 & 1.1 & 0.8 \\
\hline MH1-12-66.1 & 0.000075 & 0.0557 & 0.137 & 703 & 0.60 & 434 & 3 & & & 0.5 & 1.9 & 0.070 & 0.8 & 0.4 \\
\hline MH1-12-67.1 & 0.000016 & 0.1021 & 0.029 & 243 & 0.61 & 1703 & 13 & 1658 & 13 & 4.2 & 1.1 & 0.302 & 0.9 & 0.8 \\
\hline MH1-12-68.1 & 0.000003 & 0.0894 & 0.006 & 1171 & 0.30 & 1365 & 12 & 1411 & 6 & 2.9 & 1.0 & 0.236 & 1.0 & 0.9 \\
\hline MH1-12-69.1 & --- & 0.1873 & 0 & 280 & 0.66 & 2720 & 20 & 2719 & 7 & 13.6 & 1.0 & 0.525 & 0.9 & 0.9 \\
\hline
\end{tabular}

Mayflower Hill Formation (MH) : MH-2 Mayflower Hill, base of Mayflower Hill Formation. Waterville quadrangle, UTM Location 447348E; $4932181 \mathrm{~N}$

\begin{tabular}{|c|c|c|c|c|c|c|c|c|c|c|c|c|c|c|}
\hline MGS13-01-1.1 & -0.000049 & 0.0881 & 0.207 & 103 & 0.46 & 1349 & 14 & 1399 & 28 & 2.8 & 1.9 & 0.233 & 1.2 & 0.6 \\
\hline MGS13-01-2.1 & 0.000401 & 0.080 & 1.059 & 18 & 1.30 & 965 & 41 & 1048 & 154 & 1.7 & 8.9 & 0.161 & 4.6 & 0.5 \\
\hline MGS13-01-3.1 & 0.000057 & 0.0738 & -0.277 & 113 & 0.59 & 1096 & 12 & 1015 & 36 & 1.9 & 2.1 & 0.185 & 1.1 & 0.5 \\
\hline MGS13-01-4.1 & 0.000009 & 0.1141 & 0.002 & 204 & 0.46 & 1865 & 15 & 1863 & 16 & 5.3 & 1.3 & 0.335 & 0.9 & 0.7 \\
\hline MGS13-01-5.1 & -0.000010 & 0.0744 & 0.069 & 363 & 0.66 & 1037 & 8 & 1055 & 19 & 1.8 & 1.2 & 0.174 & 0.8 & 0.7 \\
\hline MGS13-01-6.1 & 0.000043 & 0.0823 & 0.205 & 61 & 0.20 & 1213 & 16 & 1239 & 39 & 2.3 & 2.5 & 0.207 & 1.4 & 0.6 \\
\hline MGS13-01-7.1 & 0.000011 & 0.0737 & -0.056 & 602 & 1.44 & 1045 & 7 & 1028 & 15 & 1.8 & 1.0 & 0.176 & 0.7 & 0.7 \\
\hline MGS13-01-8.1 & 0.000051 & 0.0711 & -0.038 & 226 & 0.62 & 968 & 8 & & & 1.6 & 1.7 & 0.162 & 0.9 & 0.5 \\
\hline MGS13-01-9.1 & 0.000017 & 0.2139 & 1.175 & 723 & 0.41 & 2881 & 32 & 2934 & 4 & 16.6 & 1.4 & 0.563 & 1.4 & 1.0 \\
\hline MGS13-01-10.1 & 0.000068 & 0.1011 & 0.589 & 217 & 1.24 & 1554 & 12 & 1627 & 27 & 3.8 & 1.7 & 0.273 & 0.9 & 0.5 \\
\hline MGS13-01-11.1 & --- & 0.0760 & 0.202 & 164 & 0.52 & 1051 & 10 & 1094 & 27 & 1.9 & 1.7 & 0.177 & 1.0 & 0.6 \\
\hline MGS13-01-12.1 & 0 & 0.0717 & 0.234 & 122 & 0.52 & 922 & 10 & & & 1.5 & 2.0 & 0.154 & 1.1 & 0.5 \\
\hline MGS13-01-13.1 & 0.000059 & 0.1927 & 0.893 & 41 & 0.40 & 2714 & 153 & 2760 & 107 & 13.9 & 9.5 & 0.524 & 6.9 & 0.7 \\
\hline MGS13-01-14.1 & 0.000020 & 0.0737 & -0.009 & 1327 & 0.07 & 1035 & 6 & 1026 & 11 & 1.8 & 0.8 & 0.174 & 0.7 & 0.8 \\
\hline MGS13-01-15.1 & 0.000008 & 0.0772 & -0.127 & 843 & 1.19 & 1151 & 8 & 1122 & 12 & 2.1 & 1.0 & 0.195 & 0.8 & 0.8 \\
\hline MGS13-01-16.1 & 0.000004 & 0.1011 & -0.068 & 1708 & 1.18 & 1654 & 9 & 1643 & 6 & 4.1 & 0.7 & 0.293 & 0.6 & 0.9 \\
\hline MGS13-01-17.1 & 0 & 0.1916 & 1.327 & 235 & 0.81 & 2680 & 20 & 2756 & 8 & 13.6 & 1.0 & 0.515 & 0.9 & 0.9 \\
\hline MGS13-01-18.1 & 0.000051 & 0.0796 & 0.279 & 297 & 0.22 & 1130 & 9 & 1170 & 22 & 2.1 & 1.4 & 0.192 & 0.9 & 0.6 \\
\hline MGS13-01-19.1 & 0.000205 & 0.0560 & -0.100 & 151 & 0.57 & 482 & 8 & & & 0.6 & 4.2 & 0.078 & 1.7 & 0.4 \\
\hline MGS13-01-20.1 & -0.000116 & 0.0717 & -0.348 & 64 & 0.53 & 1058 & 14 & 1025 & 56 & 1.8 & 3.1 & 0.178 & 1.5 & 0.5 \\
\hline MGS13-01-21.1 & 0.000005 & 0.0738 & 0.034 & 1394 & 0.15 & 1029 & 6 & 1034 & 9 & 1.8 & 0.8 & 0.173 & 0.6 & 0.8 \\
\hline MGS13-01-22.1 & 0.000251 & 0.0761 & 0.257 & 43 & 0.60 & 1038 & 17 & 1000 & 81 & 1.7 & 4.4 & 0.175 & 1.7 & 0.4 \\
\hline MGS13-01-23.1 & --- & 0.0820 & 0.475 & 21 & 0.39 & 1151 & 26 & 1245 & 70 & 2.2 & 4.3 & 0.196 & 2.4 & 0.6 \\
\hline MGS13-01-24.1 & 0 & 0.0572 & 0.217 & 65 & 0.85 & 432 & 6 & & & 0.5 & 7.8 & 0.069 & 1.5 & 0.2 \\
\hline MGS13-01-25.1 & 0.000209 & 0.0688 & -0.466 & 52 & 1.38 & 998 & 14 & & & 1.5 & 4.1 & 0.167 & 1.6 & 0.4 \\
\hline MGS13-01-26.1 & 0.000011 & 0.0771 & 0.129 & 286 & 0.37 & 1096 & 8 & 1120 & 19 & 2.0 & 1.3 & 0.185 & 0.8 & 0.7 \\
\hline MGS13-01-27.1 & 0 & 0.1135 & -0.001 & 110 & 0.04 & 1856 & 18 & 1856 & 18 & 5.2 & 1.5 & 0.334 & 1.1 & 0.8 \\
\hline MGS13-01-28.1 & 0.000020 & 0.0917 & 0.117 & 253 & 0.91 & 1442 & 18 & 1456 & 17 & 3.2 & 1.6 & 0.251 & 1.4 & 0.8 \\
\hline MGS13-01-29.1 & 0.000024 & 0.1047 & 0.062 & 244 & 0.87 & 1699 & 13 & 1703 & 14 & 4.3 & 1.1 & 0.302 & 0.9 & 0.8 \\
\hline MGS13-01-30.1 & 0 & 0.0758 & 0.102 & 156 & 0.67 & 1068 & 20 & 1090 & 32 & 1.9 & 2.6 & 0.180 & 2.0 & 0.8 \\
\hline MGS13-01-31.1 & --- & 0.0573 & 0.243 & 732 & 0.53 & 427 & 5 & & & 0.5 & 1.7 & 0.069 & 1.2 & 0.7 \\
\hline MGS13-01-32.1 & -0.000133 & 0.0670 & -0.902 & 30 & 0.37 & 1051 & 21 & & & 1.7 & 5.5 & 0.177 & 2.2 & 0.4 \\
\hline MGS13-01-33.1 & 0.000028 & 0.1122 & -0.041 & 232 & 0.58 & 1839 & 25 & 1829 & 51 & 5.1 & 3.2 & 0.330 & 1.6 & 0.5 \\
\hline MGS13-01-34.1 & 0.000021 & 0.0887 & 0.073 & 154 & 0.53 & 1385 & 14 & 1392 & 25 & 2.9 & 1.7 & 0.240 & 1.1 & 0.7 \\
\hline MGS13-01-35.1 & 0 & 0.0556 & -0.132 & 28 & 0.44 & 477 & 13 & & & 0.6 & 7.4 & 0.077 & 2.8 & 0.4 \\
\hline MGS13-01-36.1 & -0.000080 & 0.0821 & -0.286 & 80 & 0.58 & 1303 & 17 & 1274 & 40 & 2.6 & 2.5 & 0.224 & 1.4 & 0.6 \\
\hline MGS13-01-37.1 & -0.000013 & 0.0815 & 0.310 & 339 & 0.35 & 1173 & 12 & 1238 & 20 & 2.2 & 1.5 & 0.200 & 1.1 & 0.7 \\
\hline MGS13-01-38.1 & 0 & 0.0790 & -0.416 & 63 & 0.33 & 1253 & 23 & 1172 & 46 & 2.3 & 3.1 & 0.215 & 2.0 & 0.7 \\
\hline MGS13-01-39.1 & 0.000118 & 0.0543 & -0.269 & 157 & 0.70 & 468 & 6 & & & 0.5 & 3.8 & 0.075 & 1.3 & 0.3 \\
\hline
\end{tabular}


Appendix C: Continued.

\begin{tabular}{|c|c|c|c|c|c|c|c|c|c|c|c|c|c|c|}
\hline \multirow[b]{2}{*}{ sample $^{1}$} & \multirow[b]{2}{*}{$\begin{array}{l}\text { measured } \\
{ }^{204} \mathrm{~Pb} /{ }^{206} \mathrm{~Pb}\end{array}$} & \multirow[b]{2}{*}{$\begin{array}{l}\text { measured } \\
{ }^{207} \mathrm{~Pb} /{ }^{206} \mathrm{~Pb}\end{array}$} & \multirow[b]{2}{*}{$\begin{array}{l}\text { \%common } \\
{ }^{206} \mathrm{~Pb}\end{array}$} & \multirow[b]{2}{*}{$\begin{array}{c}\mathrm{U} \\
(\mathrm{ppm})\end{array}$} & \multirow[b]{2}{*}{$\mathrm{Th} / \mathrm{U}$} & \multicolumn{4}{|c|}{ Age (Ma) } & \multirow[b]{2}{*}{$\begin{array}{l}{ }^{207} \mathrm{~Pb} / \\
{ }^{235} \mathrm{U}^{5}\end{array}$} & \multirow[b]{2}{*}{$\begin{array}{l}\mathrm{err}^{4} \\
(\%)\end{array}$} & \multirow[b]{2}{*}{$\begin{array}{l}{ }^{206} \mathrm{~Pb} / \\
{ }^{238} \mathrm{U}^{5}\end{array}$} & \multirow[b]{2}{*}{$\begin{array}{l}\mathrm{err}^{4} \\
(\%)\end{array}$} & \multirow[b]{2}{*}{$\begin{array}{l}\text { err. } \\
\text { corr. }\end{array}$} \\
\hline & & & & & & $\begin{array}{l}{ }^{206} \mathrm{~Pb} / \\
{ }^{238} \mathrm{U}^{2}\end{array}$ & $\mathrm{err}^{4}$ & $\begin{array}{c}{ }^{207} \mathrm{~Pb} / \\
{ }^{206} \mathrm{~Pb}^{2,3}\end{array}$ & $\mathrm{err}^{4}$ & & & & & \\
\hline MGS13-01-40.1 & 0 & 0.0764 & -0.118 & 378 & 0.44 & 1130 & 22 & 1106 & 20 & 2.0 & 2.3 & 0.192 & 2.1 & 0.9 \\
\hline MGS13-01-41.1 & 0.000102 & 0.0734 & -0.006 & 212 & 0.72 & 1025 & 10 & & & 1.7 & 1.9 & 0.172 & 1.0 & 0.5 \\
\hline MGS13-01-42.1 & --- & 0.0871 & -0.025 & 61 & 0.32 & 1367 & 20 & 1362 & 115 & 2.8 & 6.2 & 0.236 & 1.6 & 0.3 \\
\hline MGS13-01-43.1 & 0.000091 & 0.0946 & 0.116 & 91 & 0.44 & 1499 & 40 & 1494 & 32 & 3.4 & 3.4 & 0.262 & 3.0 & 0.9 \\
\hline MGS13-01-44.1 & -0.000026 & 0.0867 & 0.131 & 478 & 0.40 & 1332 & 10 & 1363 & 14 & 2.8 & 1.1 & 0.229 & 0.8 & 0.7 \\
\hline MGS13-01-45.1 & 0 & 0.0877 & 0.049 & 361 & 0.32 & 1368 & 11 & 1377 & 16 & 2.9 & 1.2 & 0.236 & 0.9 & 0.7 \\
\hline MGS13-01-46.1 & 0.000030 & 0.1855 & -0.007 & 235 & 1.55 & 2703 & 21 & 2700 & 8 & 13.3 & 1.1 & 0.521 & 1.0 & 0.9 \\
\hline MGS13-01-47.1 & 0.000093 & 0.1246 & 0.051 & 67 & 0.64 & 2015 & 27 & 2005 & 26 & 6.2 & 2.1 & 0.367 & 1.5 & 0.7 \\
\hline MGS13-01-48.1 & -0.000044 & 0.0766 & -0.080 & 85 & 0.42 & 1128 & 14 & 1126 & 79 & 2.0 & 4.2 & 0.191 & 1.4 & 0.3 \\
\hline MGS13-01-49.1 & 0.000059 & 0.1174 & 0.482 & 38 & 0.92 & 1857 & 32 & 1904 & 35 & 5.4 & 2.8 & 0.334 & 2.0 & 0.7 \\
\hline MGS13-01-50.1 & -0.000058 & 0.0797 & 0.569 & 74 & 0.75 & 1074 & 15 & 1211 & 47 & 2.0 & 2.8 & 0.181 & 1.5 & 0.5 \\
\hline MGS13-01-51.1 & 0.000014 & 0.1019 & -0.077 & 183 & 0.80 & 1669 & 16 & 1655 & 18 & 4.1 & 1.5 & 0.295 & 1.1 & 0.7 \\
\hline MGS13-01-52.1 & 0.000042 & 0.0731 & -0.479 & 90 & 0.32 & 1120 & 14 & 1001 & 50 & 1.9 & 2.8 & 0.190 & 1.4 & 0.5 \\
\hline MGS13-01-53.1 & 0.000073 & 0.0775 & 0.138 & 225 & 0.42 & 1104 & 10 & 1107 & 28 & 2.0 & 1.7 & 0.187 & 1.0 & 0.6 \\
\hline MGS13-01-54.1 & 0.000020 & 0.1123 & -0.091 & 242 & 0.37 & 1847 & 16 & 1832 & 14 & 5.1 & 1.3 & 0.332 & 1.0 & 0.8 \\
\hline MGS13-01-55.1 & --- & 0.0700 & -0.552 & 60 & 0.50 & 1054 & 16 & & & 1.7 & 3.0 & 0.178 & 1.6 & 0.5 \\
\hline MGS13-01-56.1 & --- & 0.0738 & 0 & 84 & 0.60 & 1037 & 24 & 1037 & 43 & 1.8 & 3.3 & 0.174 & 2.5 & 0.8 \\
\hline MGS13-01-57.1 & 0.000035 & 0.0564 & -0.012 & 271 & 0.35 & 471 & 4 & & & 0.6 & 2.4 & 0.076 & 0.9 & 0.4 \\
\hline MGS13-01-58.1 & 0.000038 & 0.0749 & 0.228 & 398 & 0.54 & 1016 & 9 & 1052 & 23 & 1.8 & 1.5 & 0.171 & 1.0 & 0.6 \\
\hline MGS13-01-59.1 & -0.000029 & 0.0724 & -0.149 & 206 & 0.42 & 1031 & 31 & 1009 & 34 & 1.7 & 3.6 & 0.173 & 3.2 & 0.9 \\
\hline MGS13-01-60.1 & 0.000544 & 0.0769 & 0.481 & 79 & 0.66 & 1005 & 19 & & & 1.6 & 5.6 & 0.169 & 2.1 & 0.4 \\
\hline MGS13-01-61.1 & 0.000012 & 0.0869 & -0.204 & 563 & 1.06 & 1395 & 11 & 1355 & 14 & 2.9 & 1.1 & 0.242 & 0.9 & 0.8 \\
\hline MGS13-01-62.1 & 0.000044 & 0.0707 & 0.029 & 476 & 0.29 & 942 & 7 & & & 1.5 & 1.4 & 0.157 & 0.8 & 0.6 \\
\hline MGS13-01-63.1 & 0.000051 & 0.1041 & -0.116 & 110 & 0.81 & 1712 & 21 & 1685 & 25 & 4.3 & 1.9 & 0.304 & 1.4 & 0.7 \\
\hline MGS13-01-64.1 & 0.000021 & 0.0676 & -0.651 & 269 & 0.30 & 1009 & 65 & & & 1.6 & 7.2 & 0.169 & 7.0 & 1.0 \\
\hline MGS13-01-65.1 & 0.000072 & 0.0540 & -0.175 & 165 & 0.25 & 429 & 6 & & & 0.5 & 3.9 & 0.069 & 1.4 & 0.4 \\
\hline MGS13-01-66.1 & 0.000058 & 0.0804 & 0.571 & 176 & 0.28 & 1090 & 13 & 1187 & 34 & 2.0 & 2.2 & 0.184 & 1.3 & 0.6 \\
\hline
\end{tabular}

Mayflower Hill Formation (MH) : MH-3, Howland Dam. Howland quadrangle, UTM Location 0526847E/5009508N

\begin{tabular}{|c|c|c|c|c|c|c|c|c|c|c|c|c|c|c|}
\hline МH3-12-1.1 & --- & 0.0820 & 0 & 229 & 0.52 & 1224 & 11 & 1245 & 22 & 2.4 & 1.5 & 0.209 & 1.0 & 0.7 \\
\hline MH3-12-2.1 & 0.000011 & 0.0824 & 0.020 & 265 & 0.63 & 1258 & 9 & 1252 & 18 & 2.4 & 1.2 & 0.216 & 0.8 & 0.7 \\
\hline MH3-12-3.1 & 0.000032 & 0.0630 & 0.059 & 707 & 0.87 & 690 & 15 & & & 1.0 & 2.6 & 0.113 & 2.3 & 0.9 \\
\hline MH3-12-4.1 & 0.003035 & 0.1110 & 5.554 & 177 & 0.80 & 1060 & 13 & & & 1.7 & 16.4 & 0.179 & 1.4 & 0.1 \\
\hline МH3-12-5.1 & -0.000039 & 0.0573 & -0.071 & 222 & 0.58 & 470 & 4 & & & 0.6 & 2.4 & 0.076 & 1.0 & 0.4 \\
\hline MH3-12-6.1 & 0.000036 & 0.0783 & 0.067 & 105 & 0.30 & 1128 & 12 & 1141 & 36 & 2.1 & 2.2 & 0.191 & 1.2 & 0.5 \\
\hline MH3-12-7.1 & -0.000045 & 0.0790 & -0.082 & 154 & 0.35 & 1127 & 10 & 1189 & 28 & 2.1 & 1.7 & 0.191 & 1.0 & 0.6 \\
\hline MH3-12-8.1 & -0.000011 & 0.1043 & -0.019 & 253 & 0.57 & 1702 & 13 & 1704 & 15 & 4.3 & 1.2 & 0.302 & 0.9 & 0.7 \\
\hline MH3-12-9.1 & 0.000168 & 0.0564 & 0.307 & 142 & 0.96 & 444 & 9 & & & 0.5 & 4.9 & 0.071 & 2.2 & 0.4 \\
\hline MH3-12-10.1 & 0.000040 & 0.0866 & 0.074 & 151 & 0.29 & 1213 & 22 & 1339 & 25 & 2.5 & 2.3 & 0.207 & 2.0 & 0.8 \\
\hline MH3-12-11.1 & 0.000068 & 0.0592 & 0.125 & 289 & 0.86 & 548 & 6 & & & 0.7 & 2.2 & 0.089 & 1.2 & 0.6 \\
\hline MH3-12-12.1 & 0.000021 & 0.1028 & 0.039 & 226 & 0.63 & 1632 & 31 & 1669 & 16 & 4.1 & 2.3 & 0.288 & 2.2 & 0.9 \\
\hline MH3-12-13.1 & 0.000073 & 0.0638 & 0.134 & 198 & 0.85 & 654 & 12 & & & 0.9 & 3.0 & 0.107 & 2.0 & 0.7 \\
\hline MH3-12-14.1 & 0.000077 & 0.0713 & 0.140 & 58 & 0.41 & 1010 & 15 & & & 1.6 & 3.4 & 0.170 & 1.6 & 0.5 \\
\hline MH3-12-15.1 & -0.000031 & 0.0748 & -0.056 & 248 & 0.38 & 1053 & 8 & 1076 & 23 & 1.8 & 1.4 & 0.177 & 0.8 & 0.6 \\
\hline MH3-12-16.1 & 0.000171 & 0.0727 & 0.313 & 96 & 0.31 & 960 & 19 & & & 1.6 & 3.4 & 0.161 & 2.2 & 0.6 \\
\hline MH3-12-17.1 & 0.000155 & 0.0715 & 0.283 & 53 & 0.34 & 994 & 14 & & & 1.6 & 3.8 & 0.167 & 1.6 & 0.4 \\
\hline MH3-12-18.1 & 0.000275 & 0.0553 & 0.502 & 90 & 0.91 & 560 & 11 & & & 0.6 & 6.1 & 0.091 & 2.1 & 0.4 \\
\hline MH3-12-19.1 & --- & 0.0766 & 0 & 198 & 0 & 1078 & 15 & 1110 & 22 & 1.9 & 1.8 & 0.182 & 1.5 & 0.8 \\
\hline MH3-12-20.1 & 0.000014 & 0.0867 & 0.025 & 222 & 0.42 & 1319 & 12 & 1351 & 19 & 2.7 & 1.4 & 0.227 & 1.0 & 0.7 \\
\hline
\end{tabular}


Appendix C: Continued.

\begin{tabular}{|c|c|c|c|c|c|c|c|c|c|c|c|c|c|c|}
\hline \multirow[b]{2}{*}{ sample ${ }^{1}$} & \multirow[b]{2}{*}{$\begin{array}{l}\text { measured } \\
{ }^{204} \mathrm{~Pb} /{ }^{206} \mathrm{~Pb}\end{array}$} & \multirow[b]{2}{*}{$\begin{array}{l}\text { measured } \\
{ }^{207} \mathrm{~Pb} /{ }^{206} \mathrm{~Pb}\end{array}$} & \multirow[b]{2}{*}{$\begin{array}{l}\text { \%common } \\
{ }^{206} \mathrm{~Pb}\end{array}$} & \multirow[b]{2}{*}{$\begin{array}{c}\mathrm{U} \\
(\mathrm{ppm})\end{array}$} & \multirow[b]{2}{*}{$\mathrm{Th} / \mathrm{U}$} & \multicolumn{4}{|c|}{ Age (Ma) } & \multirow[b]{2}{*}{$\begin{array}{l}{ }^{207} \mathrm{~Pb} / \\
{ }^{235} \mathrm{U}^{5}\end{array}$} & \multirow[b]{2}{*}{$\begin{array}{l}\operatorname{err}^{4} \\
(\%)\end{array}$} & \multirow[b]{2}{*}{$\begin{array}{l}{ }^{206} \mathrm{~Pb} / \\
{ }^{238} \mathrm{U}^{5}\end{array}$} & \multirow[b]{2}{*}{$\begin{array}{l}\operatorname{err}^{4} \\
(\%)\end{array}$} & \multirow[b]{2}{*}{$\begin{array}{l}\text { err. } \\
\text { corr. }\end{array}$} \\
\hline & & & & & & $\begin{array}{l}{ }^{206} \mathrm{~Pb} / \\
{ }^{238} \mathrm{U}^{2}\end{array}$ & $\mathrm{err}^{4}$ & $\begin{array}{l}{ }^{207} \mathrm{~Pb} / \\
{ }^{206} \mathrm{~Pb}^{2,3}\end{array}$ & $\mathrm{err}^{4}$ & & & & & \\
\hline MH3-12-21.1 & 0.000035 & 0.0571 & 0.063 & 171 & 0.67 & 624 & 11 & & & 0.8 & 4.0 & 0.102 & 1.9 & 0.5 \\
\hline MH3-12-22.1 & --- & 0.0764 & 0 & 55 & 0.40 & 1106 & 17 & 1105 & 48 & 2.0 & 2.9 & 0.187 & 1.7 & 0.6 \\
\hline MH3-12-23.1 & 0.000043 & 0.0601 & 0.079 & 298 & 0.82 & 625 & 9 & & & 0.8 & 2.3 & 0.102 & 1.5 & 0.7 \\
\hline MH3-12-24.1 & 0.001009 & 0.0559 & 1.847 & 49 & 1.39 & 485 & 9 & & & 0.4 & 18.0 & 0.078 & 1.9 & 0.1 \\
\hline MH3-12-25.1 & --- & 0.0849 & 0 & 214 & 0.57 & 1243 & 20 & 1313 & 19 & 2.5 & 2.0 & 0.213 & 1.8 & 0.9 \\
\hline MH3-12-26.1 & 0.000053 & 0.0957 & 0.097 & 196 & 0.41 & 1486 & 12 & 1528 & 19 & 3.4 & 1.4 & 0.259 & 0.9 & 0.7 \\
\hline MH3-12-27.1 & 0.000014 & 0.0772 & 0.026 & 958 & 0.64 & 1151 & 7 & 1121 & 11 & 2.1 & 0.8 & 0.196 & 0.6 & 0.8 \\
\hline MH3-12-28.1 & 0.000039 & 0.0623 & 0.071 & 191 & 0.75 & 616 & 6 & & & 0.9 & 2.3 & 0.100 & 1.0 & 0.4 \\
\hline MH3-12-29.1 & 0.000003 & 0.0910 & 0.006 & 793 & 0.30 & 1401 & 8 & 1447 & 18 & 3.0 & 1.1 & 0.243 & 0.6 & 0.6 \\
\hline MH3-12-30.1 & 0.000097 & 0.0581 & 0.177 & 2081 & 0.31 & 439 & 6 & & & 0.6 & 1.6 & 0.071 & 1.3 & 0.8 \\
\hline MH3-12-31.1 & -0.000019 & 0.0843 & -0.035 & 168 & 0.56 & 1296 & 21 & 1305 & 24 & 2.6 & 2.2 & 0.223 & 1.8 & 0.8 \\
\hline МH3-12-32.1 & --- & 0.0606 & 0 & 107 & 0.90 & 534 & 16 & & & 0.7 & 4.1 & 0.086 & 3.0 & 0.8 \\
\hline MH3-12-33.1 & 0.000495 & 0.0539 & 0.905 & 46 & 0.55 & 421 & 8 & & & 0.4 & 12.8 & 0.067 & 1.9 & 0.1 \\
\hline MH3-12-34.1 & --- & 0.0571 & 0 & 273 & 0.68 & 485 & 4 & & & 0.6 & 2.0 & 0.078 & 0.8 & 0.4 \\
\hline MH3-12-35.1 & --- & 0.0792 & 0 & 765 & 0.52 & 1160 & 15 & 1177 & 11 & 2.2 & 1.5 & 0.197 & 1.4 & 0.9 \\
\hline MH3-12-36.1 & --- & 0.1853 & 0 & 552 & 0.67 & 2682 & 28 & 2701 & 10 & 13.2 & 1.4 & 0.516 & 1.3 & 0.9 \\
\hline MH3-12-37.1 & 0.000115 & 0.1121 & 0.210 & 189 & 0.69 & 1663 & 14 & 1809 & 18 & 4.5 & 1.4 & 0.294 & 0.9 & 0.7 \\
\hline MH3-12-38.1 & 0.000079 & 0.0579 & 0.145 & 494 & 0.54 & 485 & 7 & & & 0.6 & 2.1 & 0.078 & 1.4 & 0.7 \\
\hline MH3-12-39.1 & 0.000054 & 0.0576 & 0.098 & 354 & 1.41 & 490 & 4 & & & 0.6 & 2.1 & 0.079 & 0.8 & 0.4 \\
\hline MH3-12-40.1 & 0.000031 & 1069 & 057 & 476 & 0.44 & 1668 & 11 & 1740 & 13 & 4.3 & 1.0 & 0.295 & 0.7 & 0.7 \\
\hline MH3-12-41.1 & 0.000036 & 0.1010 & 0.066 & 209 & 1.00 & 1601 & 13 & 1633 & 17 & 3.9 & 1.3 & 0.282 & 0.9 & 0.7 \\
\hline MH3-12-42.1 & -0.000005 & 0.0726 & -0.009 & 1390 & 0.25 & 1000 & 11 & 1003 & 9 & 1.7 & 1.3 & 0.168 & 1.2 & 0.9 \\
\hline MH3-12-43.1 & 0.000068 & 0.0570 & 0.124 & 317 & 1.00 & 487 & 8 & & & 0.6 & 2.8 & 0.078 & 1.7 & 0.6 \\
\hline MH3-12-44.1 & 0.000032 & 0.0699 & 0.059 & 129 & 0.42 & 940 & 9 & & & 1.5 & 2.1 & 0.157 & 1.1 & 0.5 \\
\hline MH3-12-45.1 & -0.000013 & 0.0908 & -0.024 & 231 & 0.96 & 1440 & 19 & 1445 & 18 & 3.1 & 1.7 & 0.250 & 1.5 & 0.8 \\
\hline MH3-12-46.1 & --- & 0.0939 & 0 & 85 & 0.57 & 1452 & 17 & 1505 & 29 & 3.3 & 2.0 & 0.253 & 1.3 & 0.7 \\
\hline MH3-12-47.1 & 0.000065 & 0.0616 & 0.118 & 379 & 0.74 & 632 & 7 & & & 0.9 & 1.9 & 0.103 & 1.1 & 0.6 \\
\hline MH3-12-48.1 & 0.000006 & 0.1053 & 0.012 & 333 & 0.35 & 1753 & 12 & 1718 & 11 & 4.5 & 1.0 & 0.313 & 0.8 & 0.8 \\
\hline MH3-12-49.1 & 0.000497 & 0.0671 & 0.909 & 556 & 0.68 & 552 & 4 & & & 0.7 & 2.5 & 0.089 & 0.7 & 0.3 \\
\hline MH3-12-50.1 & -0.000083 & 0.0565 & -0.153 & 273 & 0.82 & 473 & 5 & & & 0.6 & 2.7 & 0.076 & 1.0 & 0.4 \\
\hline MH3-12-51.1 & -0.000034 & 0.0570 & -0.063 & 314 & 1.08 & 464 & 4 & & & 0.6 & 2.2 & 0.075 & 0.9 & 0.4 \\
\hline MH3-12-52.1 & -0.000155 & 0.0596 & -0.283 & 109 & 0.81 & 557 & 6 & & & 0.8 & 3.9 & 0.090 & 1.2 & 0.3 \\
\hline MH3-12-53.1 & 0.000175 & 0.0603 & 0.319 & 98 & 0.46 & 488 & 6 & & & 0.6 & 4.5 & 0.079 & 1.2 & 0.3 \\
\hline MH3-12-54.1 & 0.000012 & 0.1025 & 0.021 & 368 & 0.43 & 1661 & 12 & 1667 & 11 & 4.1 & 1.0 & 0.294 & 0.8 & 0.8 \\
\hline MH3-12-55.1 & --- & 0.1702 & 0 & 126 & 0.71 & 2580 & 24 & 2560 & 12 & 11.6 & 1.3 & 0.492 & 1.1 & 0.8 \\
\hline MH3-12-56.1 & -0.000005 & 0.0809 & -0.009 & 637 & 0.28 & 1232 & 16 & 1222 & 12 & 2.4 & 1.5 & 0.211 & 1.4 & 0.9 \\
\hline MH3-12-57.1 & -0.000099 & 0.0760 & -0.182 & 44 & 0.91 & 1080 & 18 & 1131 & 66 & 1.9 & 3.8 & 0.182 & 1.8 & 0.5 \\
\hline MH3-12-58.1 & 0.000034 & 0.1532 & 0.062 & 106 & 2.75 & 2388 & 25 & 2377 & 18 & 9.4 & 1.6 & 0.448 & 1.2 & 0.8 \\
\hline MH3-12-59.1 & 0.000363 & 0.0574 & 0.664 & 190 & 1.02 & 467 & 5 & & & 0.5 & 5.1 & 0.075 & 1.0 & 0.2 \\
\hline MH3-12-60.1 & 0.000036 & 0.0563 & 0.067 & 665 & 0.65 & 439 & 8 & & & 0.5 & 2.2 & 0.071 & 1.8 & 0.8 \\
\hline
\end{tabular}

Vassalboro Group, undifferentiated (VG) : VG-1 Sandstone with uncertain relationships with Waterville Formation. Greenfield quadrangle, UTM Location 0540695E/4994053N

\begin{tabular}{|c|c|c|c|c|c|c|c|c|c|c|c|c|c|c|}
\hline VG-1-1.1 & 0.000217 & 0.0890 & 1.007 & 1056 & 0.40 & 1217 & 14 & 1338 & 34 & 2.5 & 2.2 & 0.208 & 1.3 & 0.6 \\
\hline VG-1-2.1 & 0.000191 & 0.0571 & 0.158 & 1203 & 0.06 & 444 & 9 & & & 0.5 & 2.6 & 0.071 & 2.1 & 0.8 \\
\hline VG-1-3.1 & 0.000016 & 0.0548 & -0.150 & 578 & 0.60 & 453 & 8 & & & 0.5 & 2.2 & 0.073 & 1.8 & 0.8 \\
\hline VG-1-5.1 & 0.000036 & 0.1865 & 0.877 & 123 & 1.52 & 2659 & 32 & 2708 & 11 & 13.1 & 1.6 & 0.511 & 1.5 & 0.9 \\
\hline VG-1-4.1 & 0.000099 & 0.0957 & -0.201 & 808 & 0.36 & 1571 & 17 & 1515 & 10 & 3.6 & 1.4 & 0.276 & 1.3 & 0.9 \\
\hline VG-1-6.1 & 0.000003 & 0.0739 & -0.123 & 1157 & 0.02 & 1066 & 11 & 1038 & 9 & 1.8 & 1.2 & 0.180 & 1.1 & 0.9 \\
\hline VG-1-7.1 & 0.000899 & 0.0695 & 1.567 & 440 & 0.45 & 481 & 10 & & & 0.6 & 4.2 & 0.078 & 2.1 & 0.5 \\
\hline
\end{tabular}


Appendix C: Continued.

\begin{tabular}{|c|c|c|c|c|c|c|c|c|c|c|c|c|c|c|}
\hline \multirow[b]{2}{*}{ sample ${ }^{1}$} & \multirow[b]{2}{*}{$\begin{array}{l}\text { measured } \\
{ }^{204} \mathrm{~Pb} /{ }^{206} \mathrm{~Pb}\end{array}$} & \multirow[b]{2}{*}{$\begin{array}{l}\text { measured } \\
{ }^{207} \mathrm{~Pb} /{ }^{206} \mathrm{~Pb}\end{array}$} & \multirow[b]{2}{*}{$\begin{array}{l}\text { \%common } \\
{ }^{206} \mathrm{~Pb}\end{array}$} & \multirow[b]{2}{*}{$\begin{array}{c}\mathrm{U} \\
(\mathrm{ppm})\end{array}$} & \multirow[b]{2}{*}{$\mathrm{Th} / \mathrm{U}$} & \multicolumn{4}{|c|}{ Age (Ma) } & \multirow[b]{2}{*}{$\begin{array}{l}{ }^{207} \mathrm{~Pb} / \\
{ }^{235} \mathrm{U}^{5}\end{array}$} & \multirow[b]{2}{*}{$\begin{array}{l}\operatorname{err}^{4} \\
(\%)\end{array}$} & \multirow[b]{2}{*}{$\begin{array}{l}{ }^{206} \mathrm{~Pb} / \\
{ }^{238} \mathrm{U}^{5}\end{array}$} & \multirow[b]{2}{*}{$\begin{array}{l}\operatorname{err}^{4} \\
(\%)\end{array}$} & \multirow[b]{2}{*}{$\begin{array}{l}\text { err. } \\
\text { corr. }\end{array}$} \\
\hline & & & & & & $\begin{array}{l}{ }^{206} \mathrm{~Pb} / \\
{ }^{238} \mathrm{U}^{2}\end{array}$ & $\mathrm{err}^{4}$ & $\begin{array}{l}{ }^{207} \mathrm{~Pb} / \\
{ }^{206} \mathrm{~Pb}^{2,3}\end{array}$ & $\operatorname{err}^{4}$ & & & & & \\
\hline VG-1-8.1 & 0.000175 & 0.0786 & 0.531 & 404 & 0.32 & 1048 & 12 & 1098 & 57 & 1.9 & 3.1 & 0.176 & 1.2 & 0.4 \\
\hline VG-1-9.1 & --- & 0.0551 & 0.006 & 233 & 0.82 & 416 & 5 & & & 0.5 & 2.1 & 0.067 & 1.3 & 0.6 \\
\hline VG-1-10.1 & -0.000012 & 0.1086 & -0.183 & 288 & 0.53 & 1801 & 19 & 1779 & 11 & 4.8 & 1.3 & 0.322 & 1.2 & 0.9 \\
\hline VG-1-11.1 & -0.000090 & 0.0730 & 0.062 & 90 & 0.27 & 1002 & 23 & 1050 & 45 & 1.7 & 3.3 & 0.168 & 2.4 & 0.7 \\
\hline VG-1-12.1 & --- & 0.0903 & 0.046 & 560 & 0.50 & 1423 & 15 & 1431 & 10 & 3.1 & 1.3 & 0.247 & 1.2 & 0.9 \\
\hline VG-1-13.1 & 0.000044 & 0.0941 & 0.609 & 144 & 0.18 & 1409 & 21 & 1498 & 20 & 3.1 & 2.0 & 0.244 & 1.7 & 0.8 \\
\hline VG-1-14.1 & 0.000071 & 0.0875 & 0.542 & 143 & 0.33 & 1272 & 38 & 1349 & 25 & 2.6 & 3.6 & 0.218 & 3.3 & 0.9 \\
\hline VG-1-15.1 & 0.000050 & 0.0714 & 0.210 & 195 & 0.35 & 919 & 11 & & & 1.5 & 1.9 & 0.153 & 1.3 & 0.7 \\
\hline VG-1-16.1 & --- & 0.0607 & 0.247 & 376 & 0.46 & 556 & 8 & & & 0.8 & 2.2 & 0.090 & 1.5 & 0.7 \\
\hline VG-1-17.1 & 0.000070 & 0.0568 & 0.023 & 227 & 0.70 & 477 & 6 & & & 0.6 & 2.7 & 0.077 & 1.3 & 0.5 \\
\hline VG-1-18.1 & 0.000008 & 0.1090 & 0.120 & 463 & 0.29 & 1767 & 19 & 1781 & 9 & 4.7 & 1.3 & 0.315 & 1.2 & 0.9 \\
\hline VG-1-19.1 & 0.000009 & 0.0722 & 0.032 & 1203 & 0 & 985 & 10 & & & 1.6 & 1.7 & 0.165 & 1.1 & 0.7 \\
\hline VG-1-20.1 & 0.003412 & 0.1137 & 5.150 & 378 & 0.48 & 944 & 12 & & & 1.4 & 7.3 & 0.158 & 1.4 & 0.2 \\
\hline VG-1-21.1 & 0.002673 & 0.1003 & 4.930 & 569 & 0.27 & 605 & 93 & & & 0.8 & 67.4 & 0.098 & 16.1 & 0.2 \\
\hline VG-1-22.1* & 0.000054 & 0.1846 & 4.403 & 312 & 0.38 & 2380 & 25 & 2689 & 12 & 11.3 & 1.4 & 0.447 & 1.2 & 0.9 \\
\hline VG-1-23.1 & 0.000063 & 0.0785 & 0.515 & 1399 & 0.51 & 1051 & 26 & 1137 & 11 & 1.9 & 2.8 & 0.177 & 2.7 & 1.0 \\
\hline VG-1-24.1 & 0.004323 & 0.1136 & 4.760 & 1099 & 0.54 & 1008 & 24 & & & 1.2 & 24.3 & 0.169 & 2.6 & 0.1 \\
\hline VG-1-25.1 & 0.000031 & 0.0880 & 0.455 & 1168 & 0.24 & 1300 & 29 & 1372 & 11 & 2.7 & 2.6 & 0.223 & 2.5 & 1.0 \\
\hline VG-1-26.1 & --- & 0554 & -0.148 & 473 & 0.67 & 475 & 5 & & & 0.6 & 1.7 & 0.076 & 1.2 & 0.7 \\
\hline VG-1-27.1 & 0.000043 & 0.1103 & 0.307 & 501 & 0.92 & 1764 & 39 & 1795 & 8 & 4.8 & 2.6 & 0.315 & 2.5 & 1.0 \\
\hline VG-1-29.1 & --- & 0.0550 & -0.130 & 324 & 0.68 & 454 & 5 & & & 0.6 & 2.1 & 0.073 & 1.2 & 0.6 \\
\hline VG-1-30.1 & --- & 0.1032 & 0.023 & 181 & 0.62 & 1679 & 19 & 1682 & 15 & 4.2 & 1.5 & 0.298 & 1.3 & 0.8 \\
\hline VG-1-31.1 & 0.000032 & 0.0989 & 0.354 & 312 & 0.50 & 1549 & 28 & 1595 & 14 & 3.7 & 2.2 & 0.272 & 2.1 & 0.9 \\
\hline VG-1-32.1 & --- & 0728 & -0.086 & 7 & 0.62 & 1029 & 23 & 1010 & 48 & 1.7 & 3.4 & 0.173 & 2.4 & 0.7 \\
\hline VG-1-33.1 & --- & 0.0986 & 0.292 & 125 & 0.70 & 1553 & 18 & 1597 & 19 & 3.7 & 1.7 & 0.272 & 1.3 & 0.8 \\
\hline VG-1-34.1 & --- & 0.1076 & 0.031 & 881 & 0.67 & 1755 & 26 & 1759 & 7 & 4.6 & 1.7 & 0.313 & 1.7 & 1.0 \\
\hline VG-1-35.1 & 0.000006 & 0.0922 & -0.423 & 728 & 0.21 & 1539 & 19 & 1470 & 9 & 3.4 & 1.5 & 0.270 & 1.4 & 1.0 \\
\hline VG-1-36.1 & 0.000005 & 0.1018 & -0.033 & 363 & 0.83 & 1661 & 18 & 1655 & 10 & 4.1 & 1.3 & 0.294 & 1.2 & 0.9 \\
\hline VG-1-37.1* & 0.000170 & 1057 & -3.080 & 112 & 0.55 & 2078 & 44 & 1687 & 32 & 5.4 & 3.0 & 0.380 & 2.5 & 0.8 \\
\hline VG-1-38.1 & 0.000114 & 0.0606 & -0.027 & 44 & 0.98 & 632 & 10 & & & 0.8 & 4.7 & 0.103 & 1.7 & 0.4 \\
\hline VG-1-39.1 & 0.000024 & 0.1011 & -0.257 & 185 & 1.13 & 1680 & 25 & 1638 & 16 & 4.1 & 1.9 & 0.298 & 1.7 & 0.9 \\
\hline VG-1-42.1 & --- & 0.0567 & 0.061 & 277 & 0.09 & 461 & 6 & & & 0.6 & 2.2 & 0.074 & 1.3 & 0.6 \\
\hline VG-1-43.1 & 0.000026 & 0.0725 & -0.147 & 133 & 0.55 & 1034 & 13 & & & 1.7 & 2.1 & 0.174 & 1.4 & 0.7 \\
\hline VG-1-44.1 & --- & 0.0597 & 0.015 & 750 & 0.90 & 588 & 11 & & & 0.8 & 2.0 & 0.095 & 1.9 & 0.9 \\
\hline VG-1-45.1 & 0.000199 & 0.0572 & 0.158 & 6054 & 1.60 & 450 & 7 & & & 0.5 & 2.6 & 0.072 & 1.5 & 0.6 \\
\hline VG-1-46.1 & 0.000039 & 0.0986 & 0.451 & 617 & 0.63 & 1527 & 40 & 1587 & 9 & 3.6 & 2.9 & 0.267 & 2.9 & 1.0 \\
\hline VG-1-48.1 & 0.000539 & 0.0707 & 0.957 & 137 & 0.85 & 701 & 9 & & & 1.0 & 5.4 & 0.115 & 1.4 & 0.3 \\
\hline VG-1-49.1 & -0.000589 & 0.0580 & 0.114 & 14 & 0.32 & 499 & 13 & & & 0.7 & 14.6 & 0.080 & 2.8 & 0.2 \\
\hline VG-1-51.1* & 0.000955 & 0.0953 & 2.913 & 574 & 0.53 & 968 & 25 & 1240 & 30 & 1.8 & 3.2 & 0.162 & 2.8 & 0.9 \\
\hline VG-1-52.1 & 0.000029 & 0.0927 & -0.024 & 303 & 0.50 & 1485 & 20 & 1474 & 14 & 3.3 & 1.7 & 0.259 & 1.5 & 0.9 \\
\hline VG-1-53.1 & 0.000015 & 0.0849 & -0.265 & 404 & 0.80 & 1362 & 24 & 1310 & 14 & 2.7 & 2.1 & 0.235 & 2.0 & 0.9 \\
\hline VG-1-54.1 & 0.000038 & 0.0574 & 0.073 & 415 & 0.05 & 483 & 6 & & & 0.6 & 2.0 & 0.078 & 1.2 & 0.6 \\
\hline VG-1-56.1 & 0.000491 & 0.0664 & 1.243 & 1976 & 0.20 & 468 & 10 & & & 0.6 & 2.6 & 0.075 & 2.1 & 0.8 \\
\hline VG-1-57.1 & --- & 0.0734 & -0.011 & 329 & 0.42 & 1027 & 12 & 1024 & 17 & 1.7 & 1.5 & 0.173 & 1.2 & 0.8 \\
\hline VG-1-58.1 & 0.000005 & 0.0774 & -0.074 & 542 & 0.27 & 1147 & 17 & 1130 & 13 & 2.1 & 1.7 & 0.195 & 1.6 & 0.9 \\
\hline VG-1-59.1 & 0.000010 & 0.0898 & 0.359 & 645 & 0.48 & 1360 & 23 & 1419 & 9 & 2.9 & 1.9 & 0.235 & 1.9 & 1.0 \\
\hline VG-1-60.1 & 0.000042 & 0.0746 & 0.133 & 85 & 0.64 & 1028 & 15 & 1041 & 41 & 1.8 & 2.6 & 0.173 & 1.6 & 0.6 \\
\hline VG-1-61.1 & 0.000024 & 0.0926 & -0.046 & 99 & 0.92 & 1487 & 34 & 1474 & 50 & 3.3 & 3.6 & 0.260 & 2.5 & 0.7 \\
\hline VG-1-28.1 & -0.000011 & 0.0548 & -0.071 & 737 & 0.56 & 427 & 6 & & & 0.5 & 1.9 & 0.068 & 1.5 & 0.8 \\
\hline VG-1-41.1 & 0.000022 & 0.0769 & -0.092 & 248 & 0.27 & 1137 & 25 & 1111 & 27 & 2.0 & 2.8 & 0.193 & 2.4 & 0.9 \\
\hline
\end{tabular}


Appendix C: Continued.

\begin{tabular}{|c|c|c|c|c|c|c|c|c|c|c|c|c|c|c|}
\hline \multirow[b]{2}{*}{ sample ${ }^{1}$} & \multirow[b]{2}{*}{$\begin{array}{c}\text { measured } \\
{ }^{204} \mathrm{~Pb} /{ }^{206} \mathrm{~Pb}\end{array}$} & \multirow[b]{2}{*}{$\begin{array}{c}\text { measured } \\
{ }^{207} \mathrm{~Pb} /{ }^{206} \mathrm{~Pb}\end{array}$} & \multirow[b]{2}{*}{$\begin{array}{l}\text { \%common } \\
{ }^{206} \mathrm{~Pb}\end{array}$} & \multirow[b]{2}{*}{$\begin{array}{c}\mathrm{U} \\
(\mathrm{ppm})\end{array}$} & \multirow[b]{2}{*}{$\mathrm{Th} / \mathrm{U}$} & \multicolumn{4}{|c|}{ Age (Ma) } & \multirow[b]{2}{*}{$\begin{array}{l}{ }^{207} \mathrm{~Pb} / \\
{ }^{235} \mathrm{U}^{5}\end{array}$} & \multirow[b]{2}{*}{$\begin{array}{l}\text { err }^{4} \\
(\%)\end{array}$} & \multirow[b]{2}{*}{$\begin{array}{l}{ }^{206} \mathrm{~Pb} / \\
{ }^{238} \mathrm{U}^{5}\end{array}$} & \multirow[b]{2}{*}{$\begin{array}{l}\mathrm{err}^{4} \\
(\%)\end{array}$} & \multirow[b]{2}{*}{$\begin{array}{l}\text { err. } \\
\text { corr. }\end{array}$} \\
\hline & & & & & & $\begin{array}{l}{ }^{206} \mathrm{~Pb} / \\
{ }^{238} \mathrm{U}^{2}\end{array}$ & $\mathrm{err}^{4}$ & $\begin{array}{l}{ }^{207} \mathrm{~Pb} / \\
{ }^{206} \mathrm{~Pb}^{2,3}\end{array}$ & $\mathrm{err}^{4}$ & & & & & \\
\hline VG-1-47.1 & 0.000134 & 0.1012 & -0.055 & 1047 & 0.57 & 1651 & 24 & 1613 & 8 & 4.0 & 1.7 & 0.292 & 1.7 & 1.0 \\
\hline VG-1-50.1 & --- & 0.0513 & -0.501 & 145 & 1.25 & 425 & 8 & & & 0.5 & 4.0 & 0.068 & 1.9 & 0.5 \\
\hline VG-1-63.1* & 0.000009 & 0.0870 & 1.518 & 673 & 0.33 & 1063 & 54 & 1357 & 47 & 2.1 & 6.1 & 0.179 & 5.6 & 0.9 \\
\hline VG-1-64.1 & 0.000348 & 0.0777 & 0.265 & 1013 & 0.55 & 1079 & 27 & 1007 & 41 & 1.8 & 3.4 & 0.182 & 2.7 & 0.8 \\
\hline VG-1-65.1 & 0.000168 & 0.0552 & -0.102 & 394 & 0.29 & 452 & 9 & & & 0.5 & 3.0 & 0.073 & 2.0 & 0.7 \\
\hline \multirow[t]{2}{*}{ VG-1-66.1 } & 0.000119 & 0.0586 & -0.127 & 319 & 0.42 & 589 & 7 & & & 0.8 & 2.3 & 0.096 & 1.3 & 0.6 \\
\hline & \multicolumn{14}{|c|}{$\begin{array}{l}\text { Hutchins Corner Formation (HC) : HC-1 Lower part of Hutchins Corner Formation. Unity quadrangle, UTM location } \\
476531 \mathrm{E} / 4930780 \mathrm{~N}\end{array}$} \\
\hline MGS13-03-1.1 & 0.000281 & 0.0966 & 0.249 & 89 & 0.69 & 1514 & 21 & 1481 & 38 & 3.4 & 2.5 & 0.265 & 1.5 & 0.6 \\
\hline MGS13-03-2.1 & 0.000596 & 0.0570 & -0.634 & 32 & 0.25 & 670 & 14 & & & 0.7 & 12.2 & 0.110 & 2.1 & 0.2 \\
\hline MGS13-03-3.1 & --- & 0.0780 & -0.065 & 171 & 0.38 & 1161 & 11 & 1148 & 26 & 2.1 & 1.7 & 0.197 & 1.0 & 0.6 \\
\hline MGS13-03-4.1 & 0.000008 & 0.0756 & -0.032 & 471 & 1.18 & 1092 & 8 & 1082 & 16 & 1.9 & 1.1 & 0.185 & 0.8 & 0.7 \\
\hline MGS13-03-5.1 & 0.000054 & 0.1965 & 1.104 & 115 & 0.37 & 2736 & 26 & 2792 & 21 & 14.3 & 1.7 & 0.529 & 1.2 & 0.7 \\
\hline MGS13-03-6.1 & 0 & 0.0742 & 0.123 & 1122 & 0.18 & 1019 & 6 & 1046 & 27 & 1.8 & 1.5 & 0.171 & 0.7 & 0.5 \\
\hline MGS13-03-7.1 & 0.000047 & 0.0793 & 0.317 & 219 & 0.19 & 1114 & 10 & 1162 & 24 & 2.0 & 1.6 & 0.189 & 0.9 & 0.6 \\
\hline MGS13-03-8.1 & -0.000020 & 1016 & 0.418 & 234 & 0.96 & 1592 & 13 & 1658 & 15 & 3.9 & 1.2 & 0.280 & 0.9 & 0.7 \\
\hline MGS13-03-9.1 & .000132 & & 0.1 & & 51 & 1503 & 14 & 1493 & 25 & 3.4 & 1.7 & 0.263 & .1 & 0.6 \\
\hline MGS13-03-10.1 & 0.000081 & 0.0814 & 0.158 & 103 & 0.39 & 1198 & 13 & 1202 & 34 & 2.3 & 2.1 & 0.204 & 1.2 & 0.6 \\
\hline MGS13-03-11.1 & -0.000014 & 0.0863 & 0.025 & 211 & 0.45 & 1340 & 12 & 1349 & 20 & 2.8 & 1.4 & 0.231 & 1.0 & 0.7 \\
\hline MGS13-03-12.1 & 0.000088 & .0712 & -0.031 & 216 & 0.96 & 970 & 9 & & & 1.6 & 1.8 & 0.162 & 1.0 & 0.5 \\
\hline MGS13-03-13.1 & 0 & 0779 & -0.049 & 229 & 0.19 & 1154 & 10 & 1144 & 22 & 2.1 & 1.4 & 0.196 & 0.9 & 0.6 \\
\hline MGS13-03 & .000031 & & & & & 1173 & 13 & 1230 & & 2.2 & & 0.200 & .2 & 0.6 \\
\hline MGS13-03-15.1 & 0.000009 & 0.1127 & 0.130 & 233 & 0.28 & 1828 & 15 & 1842 & 16 & 5.1 & 1.3 & 0.328 & 0.9 & 0.7 \\
\hline MGS13-03-16.1 & 0.000565 & 0.0718 & 0.132 & 42 & 1.53 & 941 & 16 & & & 1.4 & 6.5 & 0.157 & 1.8 & 0.3 \\
\hline MGS13-03-17.1 & 0.000014 & 0846 & 0.191 & 245 & 0.16 & 1271 & 11 & 1302 & 21 & 2.5 & 1.4 & 0.218 & 0.9 & 0.7 \\
\hline MGS13-03-18.1 & 0.000030 & 791 & -0.064 & 110 & 0.55 & 1187 & 13 & 1164 & 33 & 2.2 & 2.0 & 0.202 & 1.2 & 0.6 \\
\hline MGS13-03-19.1 & 0.000030 & & 030 & & 45 & 1067 & 8 & 1062 & 20 & 1.9 & 1.3 & 0.180 & 0.8 & 0.6 \\
\hline MGS13-03-20.1 & 0 & 0.0782 & 0.195 & 129 & 0.40 & 1111 & 12 & 1151 & 29 & 2.0 & 1.9 & 0.188 & 1.1 & 0.6 \\
\hline MGS13-03-21.1 & --- & 0.0759 & 0.259 & 83 & 0.39 & 1035 & 13 & 1091 & 40 & 1.8 & 2.4 & 0.174 & 1.3 & 0.6 \\
\hline MGS13-03-22.1 & 0.001791 & 0.0730 & -0.021 & 15 & 0.99 & 991 & 29 & & & 1.1 & 23.5 & 0.166 & 3.1 & 0.1 \\
\hline MGS13-03-23.1 & -0.000017 & 0713 & 107 & 256 & 0.40 & 940 & 8 & & & 1.5 & 1.5 & 0.157 & 0.9 & 0.6 \\
\hline MGS13-03-24.1 & 000048 & 771 & -0.192 & & 43 & 1163 & 13 & 1107 & 31 & 2.1 & 2.0 & 0.198 & 1.3 & 0.6 \\
\hline MGS13-03-25.1 & 0.000009 & & 0.001 & 1808 & 0.58 & 1167 & 11 & 1164 & 8 & 2.2 & & 0.199 & 1.1 & 0.9 \\
\hline MGS13-03-26.1 & 0 & 0.0749 & -0.042 & 260 & 0.54 & 1075 & 9 & 1067 & 22 & 1.9 & 1.4 & 0.182 & 0.9 & 0.6 \\
\hline MGS13-03-27.1 & -0.000067 & 0.2191 & -2.669 & 32 & 0.38 & 3074 & 48 & 2979 & 18 & 18.5 & 2.3 & 0.611 & 2.0 & 0.9 \\
\hline MGS13-03-28.1 & .000029 & 0827 & 0.345 & 203 & 0.29 & 1194 & 12 & 1252 & 27 & 2.3 & 1.7 & 0.204 & 1.1 & 0.6 \\
\hline MGS13-03-29.1 & 0.000021 & 0.0714 & 0.056 & 184 & 0.26 & 957 & 9 & & & 1.6 & 1.7 & 0.160 & 1.0 & 0.6 \\
\hline MGS13-03-30.1 & 000013 & & 0.171 & & 0.51 & 465 & 3 & & & 0.6 & 1.4 & 0.075 & 0.7 & 0.5 \\
\hline MGS13-03-31.1 & 0.000194 & 0.0571 & 0.098 & 348 & 0.61 & 463 & 4 & & & 0.6 & 2.7 & 0.074 & 0.9 & 0.3 \\
\hline MGS13-03-32.1 & 0 & 0.0553 & -0.127 & 178 & 0.35 & 465 & 4 & & & 0.6 & 2.6 & 0.075 & 1.0 & 0.4 \\
\hline MGS13-03-33.1 & .000064 & 0.0931 & 0.059 & 142 & 1.45 & 1480 & 32 & 1472 & 26 & 3.3 & 2.8 & 0.258 & 2.4 & 0.9 \\
\hline MGS13-03-34.1 & 0.000066 & 0.0724 & -0.258 & 194 & 0.36 & 1053 & 11 & & & 1.7 & 1.9 & 0.177 & 1.1 & 0.6 \\
\hline MGS13-03-35.1 & 0.000054 & 0.0734 & -0.034 & 321 & 0.36 & 1031 & 8 & 1003 & 22 & 1.7 & 1.4 & 0.173 & 0.8 & 0.6 \\
\hline MGS13-03-36.1 & 0.000169 & 0.0894 & 0.207 & 43 & 0.65 & 1373 & 21 & 1360 & 50 & 2.8 & 3.1 & 0.237 & 1.7 & 0.5 \\
\hline MGS13-03-37.1 & -0.000014 & 0.0733 & -0.024 & 257 & 0.35 & 1028 & 8 & 1028 & 27 & 1.8 & 1.6 & 0.173 & 0.9 & 0.5 \\
\hline MGS13-03-38.1 & 0 & 0.0950 & 0.614 & 54 & 0.37 & 1429 & 20 & 1529 & 34 & 3.3 & 2.3 & 0.248 & 1.5 & 0.6 \\
\hline MGS13-03-39.1 & 0.000121 & 0.0768 & 0.406 & 143 & 0.49 & 1026 & 10 & 1069 & 36 & 1.8 & 2.1 & 0.172 & 1.0 & 0.5 \\
\hline MGS13-03-40.1 & 0.000017 & 0.0888 & 0.076 & 325 & 0.38 & 1386 & 10 & 1394 & 16 & 2.9 & 1.2 & 0.240 & 0.8 & 0.7 \\
\hline MGS13-03-41.1 & 0.000020 & 0.0801 & 0.258 & 151 & 0.34 & 1148 & 11 & 1193 & 27 & 2.1 & 1.7 & 0.195 & 1.0 & 0.6 \\
\hline
\end{tabular}


Appendix C: Continued.

\begin{tabular}{|c|c|c|c|c|c|c|c|c|c|c|c|c|c|c|}
\hline \multirow[b]{2}{*}{ sample ${ }^{1}$} & \multirow[b]{2}{*}{$\begin{array}{l}\text { measured } \\
{ }^{204} \mathrm{~Pb} /{ }^{206} \mathrm{~Pb}\end{array}$} & \multirow[b]{2}{*}{$\begin{array}{l}\text { measured } \\
{ }^{207} \mathrm{~Pb} /{ }^{206} \mathrm{~Pb}\end{array}$} & \multirow[b]{2}{*}{$\begin{array}{l}\text { \%common } \\
{ }^{206} \mathrm{~Pb}\end{array}$} & \multirow[b]{2}{*}{$\begin{array}{c}\mathrm{U} \\
(\mathrm{ppm})\end{array}$} & \multirow[b]{2}{*}{$\mathrm{Th} / \mathrm{U}$} & \multicolumn{4}{|c|}{ Age (Ma) } & \multirow[b]{2}{*}{$\begin{array}{l}{ }^{207} \mathrm{~Pb} / \\
{ }^{235} \mathrm{U}^{5}\end{array}$} & \multirow[b]{2}{*}{$\begin{array}{l}\operatorname{err}^{4} \\
(\%)\end{array}$} & \multirow[b]{2}{*}{${ }^{206} \mathrm{~Pb} /$} & \multirow[b]{2}{*}{$\begin{array}{l}\mathrm{err}^{4} \\
(\%)\end{array}$} & \multirow[b]{2}{*}{$\begin{array}{l}\text { err. } \\
\text { corr. }\end{array}$} \\
\hline & & & & & & $\begin{array}{l}{ }^{206} \mathrm{~Pb} / \\
{ }^{238} \mathrm{U}^{2}\end{array}$ & $\mathrm{err}^{4}$ & $\begin{array}{l}{ }^{207} \mathrm{~Pb} / \\
{ }^{206} \mathrm{~Pb}^{2,3}\end{array}$ & $\mathrm{err}^{4}$ & & & & & \\
\hline MGS13-03-42.1 & 0 & 0.0558 & -0.076 & 85 & 0.48 & 468 & 6 & & & 0.6 & 3.4 & 0.075 & 1.2 & 0.4 \\
\hline MGS13-03-43.1 & 0.000055 & 0.0771 & 0.161 & 116 & 0.82 & 1090 & 11 & 1104 & 34 & 1.9 & 2.0 & 0.184 & 1.1 & 0.5 \\
\hline MGS13-03-44.1 & 0 & 0.0612 & -0.064 & 272 & 0.57 & 666 & 5 & & & 0.9 & 1.7 & 0.109 & 0.9 & 0.5 \\
\hline MGS13-03-46.1 & 0 & 0.0597 & -0.073 & 95 & 0.48 & 613 & 7 & & & 0.8 & 2.8 & 0.100 & 1.2 & 0.4 \\
\hline MGS13-03-47.1 & 0.000036 & 0.1117 & -0.451 & 412 & 0.39 & 1881 & 13 & 1819 & 10 & 5.2 & 0.9 & 0.339 & 0.8 & 0.8 \\
\hline MGS13-03-48.1 & 0.000032 & 0.1055 & -0.386 & 184 & 0.46 & 1773 & 15 & 1715 & 27 & 4.6 & 1.8 & 0.317 & 1.0 & 0.5 \\
\hline MGS13-03-49.1 & 0.000064 & 0.0809 & -0.036 & 367 & 0.35 & 1224 & 22 & 1196 & 18 & 2.3 & 2.2 & 0.209 & 2.0 & 0.9 \\
\hline MGS13-03-50.1 & 0.000041 & 0.0929 & -0.16 & 55 & 0.38 & 1510 & 36 & 1473 & 35 & 3.4 & 3.2 & 0.264 & 2.7 & 0.8 \\
\hline MGS13-03-51.1 & 0 & 0.1117 & -0.049 & 202 & 0.54 & 1834 & 15 & 1828 & 13 & 5.1 & 1.2 & 0.329 & 0.9 & 0.8 \\
\hline MGS13-03-52.1 & 0.000083 & 0.0788 & -0.052 & 69 & 0.57 & 1177 & 15 & 1138 & 43 & 2.1 & 2.5 & 0.200 & 1.3 & 0.5 \\
\hline MGS13-03-53.1 & 0.000197 & 0.0839 & 0.093 & 69 & 0.88 & 1269 & 16 & 1224 & 47 & 2.4 & 2.7 & 0.218 & 1.4 & 0.5 \\
\hline MGS13-03-54.1 & 0.000055 & 0.0603 & 0.223 & 236 & 0.58 & 550 & 5 & & & 0.7 & 2.2 & 0.089 & 0.9 & 0.4 \\
\hline MGS13-03-55.1 & 0.000086 & 0.0775 & 0.433 & 86 & 0.40 & 1042 & 13 & 1104 & 52 & 1.8 & 2.9 & 0.175 & 1.3 & 0.5 \\
\hline MGS13-03-56.1 & 0.000027 & 0.0924 & 0.172 & 790 & 0.42 & 1447 & 9 & 1468 & 9 & 3.2 & 0.8 & 0.252 & 0.7 & 0.8 \\
\hline MGS13-03-57.1 & 0.000371 & 0.0716 & -0.374 & 29 & 0.65 & 1052 & 20 & & & 1.6 & 6.3 & 0.177 & 2.1 & 0.3 \\
\hline MGS13-03-58.1 & 0.000016 & 0.0765 & 0.224 & 224 & 0.40 & 1059 & 9 & 1101 & 24 & 1.9 & 1.5 & 0.179 & 0.9 & 0.6 \\
\hline MGS13-03-59.1 & -0.000068 & 0.0553 & -0.015 & 452 & 0.62 & 431 & 3 & & & 0.5 & 1.8 & 0.069 & 0.8 & 0.4 \\
\hline MGS13-03-60.1 & 0.000063 & 0.0733 & -0.060 & 334 & 0.25 & 1034 & 8 & & & 1.7 & 1.4 & 0.174 & 0.8 & 0.6 \\
\hline MGS13-03-61.1 & 0.001208 & 0.1020 & 1.276 & 84 & 0.61 & 1438 & 20 & 1316 & 82 & 2.9 & 4.5 & 0.250 & 1.5 & 0.3 \\
\hline MGS13-03-62.1 & 0.000067 & 0.0988 & -0.450 & 92 & 0.69 & 1666 & 21 & 1585 & 31 & 4.0 & 2.2 & 0.295 & 1.4 & 0.7 \\
\hline MGS13-03-63.1 & 0.000072 & 0.0578 & 0.168 & 320 & 0.16 & 471 & 4 & & & 0.6 & 2.5 & 0.076 & 0.9 & 0.4 \\
\hline MGS13-03-64.1 & 0.000292 & 0.1017 & 0.058 & 36 & 1.28 & 1641 & 31 & 1581 & 58 & 3.9 & 3.8 & 0.290 & 2.1 & 0.6 \\
\hline MGS13-03-65.1 & 0.000093 & 0.0909 & -0.083 & 135 & 0.58 & 1456 & 16 & 1417 & 29 & 3.1 & 1.9 & 0.253 & 1.2 & 0.6 \\
\hline MGS13-03-66.1 & 0.000036 & 0.1789 & 1.946 & 196 & 0.87 & 2512 & 22 & 2639 & 28 & 11.7 & 2.0 & 0.476 & 1.1 & 0.5 \\
\hline
\end{tabular}

Madrid Formation (MA) : MA-1 Mattawamkeag quadrangle, UTM Location 0551778E/5043667N

\begin{tabular}{|c|c|c|c|c|c|c|c|c|c|c|c|c|c|c|}
\hline Ma1-12-1.1 & 0.000020 & 0.2086 & 0.037 & 270 & 0.35 & 2843 & 22 & 2893 & 7 & 15.93 & 1.1 & 0.554 & 1.0 & 0.9 \\
\hline Ma1-12-2.1 & 0.000043 & 0.1026 & 0.079 & 178 & 0.76 & 1617 & 15 & 1661 & 19 & 4.01 & 1.5 & 0.285 & 1.1 & 0.7 \\
\hline Ma1-12-3.1 & --- & 0.1324 & 0 & 123 & 0.68 & 2146 & 22 & 2130 & 16 & 7.21 & 1.5 & 0.395 & 1.2 & 0.8 \\
\hline Ma1-12-4.1 & 0.000048 & 0.0764 & 0.088 & 163 & 0.4 & 1063 & 11 & 1088 & 31 & 1.87 & 1.9 & 0.179 & 1.1 & 0.6 \\
\hline Ma1-12-5.1 & 0.000021 & 0.1228 & 0.038 & 254 & 0.55 & 1978 & 23 & 1993 & 11 & 6.07 & 1.5 & 0.359 & 1.3 & 0.9 \\
\hline Ma1-12-6.1 & 0.000009 & 0.0751 & 0.017 & 382 & 0.54 & 1083 & 9 & 1067 & 18 & 1.89 & 1.2 & 0.183 & 0.9 & 0.7 \\
\hline Ma1-12-7.1 & 0.000069 & 0.0747 & 0.126 & 114 & 0.63 & 1050 & 13 & 1033 & 39 & 1.80 & 2.3 & 0.177 & 1.3 & 0.6 \\
\hline Ma1-12-8.1 & 0.000010 & 0.0785 & 0.018 & 383 & 0.2 & 1122 & 9 & 1155 & 17 & 2.05 & 1.2 & 0.190 & 0.9 & 0.7 \\
\hline Ma1-12-9.1 & 0.000035 & 0.2016 & 0.065 & 191 & 1.07 & 2716 & 23 & 2835 & 8 & 14.53 & 1.2 & 0.524 & 1.0 & 0.9 \\
\hline Ma1-12-10.1 & 0.000014 & 0.0568 & 0.026 & 678 & 0.87 & 461 & 4 & & & 0.58 & 1.5 & 0.074 & 0.8 & 0.6 \\
\hline Ma1-12-11.1 & 0.000079 & 0.0756 & 0.144 & 98 & 0.93 & 1076 & 13 & 1054 & 42 & 1.87 & 2.4 & 0.182 & 1.3 & 0.5 \\
\hline Ma1-12-12.1 & -0.000019 & 0.0945 & -0.036 & 270 & 0.55 & 1493 & 13 & 1524 & 16 & 3.41 & 1.3 & 0.261 & 0.9 & 0.8 \\
\hline Ma1-12-13.1 & 0.000026 & 0.0710 & 0.048 & 257 & 0.27 & 941 & 8 & & & 1.53 & 1.4 & 0.157 & 0.9 & 0.6 \\
\hline Ma1-12-14.1 & 0.000005 & 0.1857 & 0.008 & 218 & 0.68 & 2714 & 21 & 2704 & 7 & 13.40 & 1.0 & 0.524 & 0.9 & 0.9 \\
\hline Ma1-12-15.1 & 0 & 0.0565 & 0 & 171 & 0.4 & 434 & 4 & & & 0.54 & 2.5 & 0.070 & 1.0 & 0.4 \\
\hline Ma1-12-16.1 & 0.000019 & 0.0881 & 0.034 & 286 & 0.46 & 1343 & 18 & 1378 & 16 & 2.81 & 1.7 & 0.232 & 1.5 & 0.9 \\
\hline Ma1-12-17.1 & 0.000014 & 0.1884 & 0.025 & 348 & 1.08 & 2748 & 21 & 2727 & 7 & 13.79 & 1.0 & 0.532 & 0.9 & 0.9 \\
\hline Ma1-12-18.1 & 0.000015 & 0.1837 & 0.028 & 186 & 0.85 & 2660 & 23 & 2684 & 9 & 12.92 & 1.2 & 0.511 & 1.1 & 0.9 \\
\hline Ma1-12-19.1 & 0 & 0.0998 & 0 & 162 & 0.3 & 1647 & 17 & 1621 & 20 & 4.01 & 1.6 & 0.291 & 1.2 & 0.7 \\
\hline Ma1-12-20.1 & 0.000059 & 0.0903 & 0.108 & 249 & 0.61 & 1407 & 20 & 1415 & 19 & 3.01 & 1.9 & 0.244 & 1.6 & 0.8 \\
\hline Ma1-12-21.1 & 0.000629 & 0.0761 & 1.151 & 13 & 0.26 & 1122 & 35 & & & 1.76 & 11.7 & 0.190 & 3.4 & 0.3 \\
\hline Ma1-12-22.1 & 0.000017 & 0.0726 & 0.032 & 229 & 0.32 & 1035 & 9 & & & 1.74 & 1.6 & 0.174 & 1.0 & 0.6 \\
\hline Ma1-12-23.1 & --- & 0.0990 & 0 & 121 & 0.47 & 1526 & 16 & 1606 & 20 & 3.65 & 1.6 & 0.267 & 1.2 & 0.7 \\
\hline Ma1-12-24.1 & --- & 0.0745 & 0 & 116 & 0.38 & 1058 & 12 & 1055 & 34 & 1.83 & 2.1 & 0.178 & 1.2 & 0.6 \\
\hline
\end{tabular}


Appendix C: Continued.

\begin{tabular}{|c|c|c|c|c|c|c|c|c|c|c|c|c|c|c|}
\hline \multirow[b]{2}{*}{ sample ${ }^{1}$} & \multirow[b]{2}{*}{$\begin{array}{l}\text { measured } \\
{ }^{204} \mathrm{~Pb} /{ }^{206} \mathrm{~Pb}\end{array}$} & \multirow[b]{2}{*}{$\begin{array}{l}\text { measured } \\
{ }^{207} \mathrm{~Pb} /{ }^{206} \mathrm{~Pb}\end{array}$} & \multirow[b]{2}{*}{$\begin{array}{l}\text { \%common } \\
{ }^{206} \mathrm{~Pb}\end{array}$} & \multirow[b]{2}{*}{$\begin{array}{c}\mathrm{U} \\
(\mathrm{ppm})\end{array}$} & \multirow[b]{2}{*}{$\mathrm{Th} / \mathrm{U}$} & \multicolumn{4}{|c|}{ Age (Ma) } & \multirow[b]{2}{*}{$\begin{array}{l}{ }^{207} \mathrm{~Pb} / \\
{ }^{235} \mathrm{U}^{5}\end{array}$} & \multirow[b]{2}{*}{$\begin{array}{l}\operatorname{err}^{4} \\
(\%)\end{array}$} & \multirow[b]{2}{*}{$\begin{array}{l}{ }^{206} \mathrm{~Pb} / \\
{ }^{238} \mathrm{U}^{5}\end{array}$} & \multirow[b]{2}{*}{$\begin{array}{l}\operatorname{err}^{4} \\
(\%)\end{array}$} & \multirow[b]{2}{*}{$\begin{array}{l}\text { err. } \\
\text { corr. }\end{array}$} \\
\hline & & & & & & $\begin{array}{l}{ }^{206} \mathrm{~Pb} / \\
{ }^{238} \mathrm{U}^{2}\end{array}$ & $\mathrm{err}^{4}$ & $\begin{array}{l}{ }^{207} \mathrm{~Pb} / \\
{ }^{206} \mathrm{~Pb}^{2,3}\end{array}$ & $\operatorname{err}^{4}$ & & & & & \\
\hline Ma1-12-25.1 & 0.000037 & 0.0996 & 0.067 & 122 & 0.53 & 1678 & 17 & 1607 & 21 & 4.06 & 1.6 & 0.297 & 1.2 & 0.7 \\
\hline Ma1-12-26.1* & 0.000049 & 0.1157 & 0.089 & 731 & 0.28 & 1330 & 19 & 1880 & 7 & 3.63 & 1.6 & 0.229 & 1.6 & 1.0 \\
\hline Ma1-12-27.1 & 0.000024 & 0.0716 & 0.044 & 214 & 0.44 & 930 & 9 & & & 1.52 & 1.8 & 0.155 & 1.0 & 0.6 \\
\hline Ma1-12-28.1 & 0 & 0.0680 & 0 & 103 & 0.52 & 906 & 12 & & & 1.42 & 2.4 & 0.151 & 1.4 & 0.6 \\
\hline Ma1-12-29.1 & -0.000005 & 0.0761 & -0.008 & 669 & 0.02 & 1114 & 8 & 1099 & 12 & 1.98 & 1.0 & 0.189 & 0.8 & 0.8 \\
\hline Ma1-12-30.1 & 0.000077 & 0.0565 & 0.140 & 506 & 0.58 & 458 & 4 & & & 0.56 & 1.9 & 0.074 & 0.8 & 0.4 \\
\hline Ma1-12-31.1 & 0.000064 & 0.0737 & 0.118 & 64 & 0.53 & 997 & 14 & 1009 & 54 & 1.68 & 3.1 & 0.167 & 1.5 & 0.5 \\
\hline Ma1-12-32.1 & 0.000063 & 0.0712 & 0.115 & 137 & 1.44 & 943 & 10 & & & 1.53 & 2.2 & 0.157 & 1.2 & 0.5 \\
\hline Ma1-12-33.1 & 0.000027 & 0.0709 & 0.049 & 332 & 0.37 & 921 & 8 & & & 1.49 & 1.4 & 0.154 & 0.9 & 0.6 \\
\hline Ma1-12-34.1 & 0.000008 & 0.0777 & 0.015 & 745 & 0.25 & 1126 & 8 & 1136 & 12 & 2.04 & 1.0 & 0.191 & 0.8 & 0.8 \\
\hline Ma1-12-35.1 & 0.000049 & 0.0556 & 0.089 & 430 & 0.54 & 464 & 4 & & & 0.57 & 2.0 & 0.075 & 0.9 & 0.4 \\
\hline Ma1-12-36.1 & 0.000342 & 0.0583 & 0.626 & 111 & 0.84 & 470 & 6 & & & 0.56 & 5.9 & 0.076 & 1.3 & 0.2 \\
\hline Ma1-12-37.1 & 0.000030 & 0.0712 & 0.055 & 350 & 0.28 & 920 & 7 & & & 1.50 & 1.3 & 0.153 & 0.9 & 0.7 \\
\hline Ma1-12-38.1 & -0.000060 & 0.0574 & -0.110 & 307 & 0.23 & 472 & 7 & & & 0.61 & 2.8 & 0.076 & 1.6 & 0.6 \\
\hline Ma1-12-39.1 & 0.000588 & 0.0889 & 1.076 & 24 & 0.86 & 1287 & 29 & 1210 & 124 & 2.45 & 6.8 & 0.221 & 2.5 & 0.4 \\
\hline Ma1-12-40.1 & 0.000005 & 0.0860 & 0.010 & 1140 & 0.28 & 1310 & 10 & 1337 & 7 & 2.67 & 0.9 & 0.225 & 0.9 & 0.9 \\
\hline Ma1-12-41.1 & 0.000016 & 0.2003 & 0.029 & 148 & 0.87 & 2849 & 25 & 2827 & 9 & 15.34 & 1.2 & 0.556 & 1.1 & 0.9 \\
\hline Ma1-12-42.1 & 0.000133 & 0.1009 & 0.243 & 138 & 0.39 & 1595 & 20 & 1606 & 26 & 3.83 & 2.0 & 0.281 & 1.4 & 0.7 \\
\hline Ma1-12-43.1 & 0.000108 & .0727 & 197 & 121 & 0.38 & 978 & 11 & & & 1.61 & 2.5 & 0.164 & 1.2 & 0.5 \\
\hline Ma1-12-44.1 & --- & 0.1011 & 0 & 237 & 0.56 & 1644 & 14 & 1644 & 13 & 4.05 & 1.2 & 0.290 & 0.9 & 0.8 \\
\hline Ma1-12-45.1 & --- & 0.0743 & 0 & 125 & 0.29 & 953 & 10 & 1051 & 31 & 1.63 & 1.9 & 0.159 & 1.1 & 0.6 \\
\hline Ma1-12-46.1 & 0.000003 & 0.0730 & 0.006 & 1242 & 0.25 & 999 & 7 & 1013 & 10 & 1.69 & 0.9 & 0.168 & 0.7 & 0.8 \\
\hline Ma1-12-47.1* & 0.000024 & 0.1756 & 0.043 & 174 & 1.02 & 2217 & 21 & 2609 & 113 & 9.92 & 6.8 & 0.410 & 1.1 & 0.2 \\
\hline Ma1-12-48.1 & 0.000094 & 566 & .171 & 186 & 0.84 & 469 & 5 & & & 0.57 & 3.0 & 0.075 & 1.0 & 0.3 \\
\hline Ma1-12-49.1 & --- & 0.0756 & 0 & 118 & 0.57 & 1063 & 11 & 1085 & 31 & 1.87 & 1.9 & 0.179 & 1.2 & 0.6 \\
\hline Ma1-12-50.1 & 0.000018 & 0.1875 & 0.033 & 306 & 0.78 & 2688 & 36 & 2719 & 6 & 13.36 & 1.7 & 0.517 & 1.6 & 1.0 \\
\hline Ma1-12-51.1 & 0.000013 & 0.0718 & 0.023 & 337 & 0.51 & 958 & 8 & & & 1.58 & 1.4 & 0.160 & 0.9 & 0.7 \\
\hline Ma1-12-52.1 & --- & 0.0788 & 0 & 258 & 0.61 & 1178 & 18 & 1166 & 20 & 2.18 & 2.0 & 0.201 & 1.7 & 0.9 \\
\hline Ma1-12-53.1 & 0.000173 & .0738 & 0.317 & 49 & 0.7 & 972 & 15 & & & 1.60 & 4.1 & 0.163 & 1.7 & 0.4 \\
\hline Ma1-12-54.1 & --- & 0.0735 & 0 & 401 & 0.39 & 1048 & 9 & 1026 & 16 & 1.79 & 1.2 & 0.176 & 0.9 & 0.7 \\
\hline Ma1-12-55.1 & 0.000066 & 0.0812 & 0.12 & 299 & 0.58 & 1217 & 10 & 1203 & 20 & 2.30 & 1.4 & 0.208 & 0.9 & 0.7 \\
\hline Ma1-12-56.1 & -0.000024 & 0.0763 & -0.044 & 135 & 0.39 & 1173 & 14 & 1111 & 34 & 2.11 & 2.1 & 0.200 & 1.3 & 0.6 \\
\hline Ma1-12-57.1 & --- & 0.0954 & 0 & 136 & 0.46 & 1556 & 16 & 1536 & 20 & 3.59 & 1.6 & 0.273 & 1.1 & 0.7 \\
\hline Ma1-12-58.1 & 0.000309 & 0685 & 565 & 28 & 0.87 & 1049 & 22 & & & 1.56 & 6.7 & 0.177 & 2.3 & 0.3 \\
\hline Ma1-12-59.1 & 0.000022 & 0.0708 & 0.040 & 304 & 0.3 & 946 & 16 & & & 1.54 & 2.1 & 0.158 & 1.9 & 0.9 \\
\hline Ma1-12-60.1 & 0.000033 & 0.1012 & 0.059 & 281 & 0.37 & 1611 & 16 & 1638 & 16 & 3.94 & 1.4 & 0.284 & 1.1 & 0.8 \\
\hline Ma1-12-61.1 & 0.000076 & 0.0562 & 0.140 & 1401 & 0.52 & 501 & 4 & & & 0.61 & 1.4 & 0.081 & 0.9 & 0.7 \\
\hline Ma1-12-62.1 & 0.000198 & 0.0588 & 0.363 & 202 & 0.63 & 473 & 5 & & & 0.59 & 3.7 & 0.076 & 1.1 & 0.3 \\
\hline Ma1-12-63.1 & 0.000259 & 0.0559 & 0.475 & 180 & 0.67 & 467 & 5 & & & 0.54 & 3.9 & 0.075 & 1.0 & 0.3 \\
\hline Ma1-12-64.1 & 0.000206 & 0.1020 & 0.377 & 1201 & 0.08 & 1619 & 11 & 1608 & 13 & 3.90 & 1.0 & 0.286 & 0.7 & 0.7 \\
\hline Ma1-12-65.1 & 0.000103 & 0.0723 & 0.189 & 71 & 0.52 & 941 & 13 & & & 1.53 & 2.9 & 0.157 & 1.4 & 0.5 \\
\hline Ma1-12-66.1 & 0.000084 & 0.0556 & 0.153 & 550 & 0.35 & 447 & 5 & & & 0.54 & 2.0 & 0.072 & 1.2 & 0.6 \\
\hline Ma1-12-67.1 & 0.000006 & 0.0556 & 0.012 & 1204 & 0.51 & 450 & 3 & & & 0.55 & 1.1 & 0.072 & 0.8 & 0.7 \\
\hline Ma1-12-68.1 & 0.000020 & 0.0771 & 0.036 & 148 & 0.39 & 1027 & 10 & 1115 & 26 & 1.83 & 1.7 & 0.173 & 1.0 & 0.6 \\
\hline Ma1-12-69.1 & 0.000027 & 0.0628 & 0.049 & 335 & 0.53 & 734 & 6 & & & 1.04 & 1.5 & 0.121 & 0.9 & 0.6 \\
\hline Ma1-12-70.1 & 0.000038 & 0.0573 & 0.070 & 517 & 0.44 & 472 & 4 & & & 0.59 & 1.5 & 0.076 & 0.8 & 0.5 \\
\hline Ma1-12-71.1 & --- & 0.0567 & 0 & 180 & 0.62 & 398 & 4 & & & 0.50 & 2.9 & 0.064 & 1.1 & 0.4 \\
\hline Ma1-12-72.1 & 0 & 0.0568 & 0 & 701 & 0.63 & 460 & 3 & & & 0.58 & 1.4 & 0.074 & 0.8 & 0.6 \\
\hline Ma1-12-73.1 & 0.000147 & 0.0589 & 0.269 & 982 & 0.07 & 471 & 5 & & & 0.59 & 1.7 & 0.076 & 1.1 & 0.6 \\
\hline Ma1-12-74.1 & 0.000061 & 0.0570 & 0.111 & 618 & 0.98 & 470 & 8 & & & 0.58 & 2.2 & 0.076 & 1.7 & 0.7 \\
\hline
\end{tabular}


Appendix C: Continued.

\begin{tabular}{|c|c|c|c|c|c|c|c|c|c|c|c|c|c|c|}
\hline \multirow[b]{2}{*}{ sample ${ }^{1}$} & \multirow[b]{2}{*}{$\begin{array}{l}\text { measured } \\
{ }^{204} \mathrm{~Pb} /{ }^{206} \mathrm{~Pb}\end{array}$} & \multirow[b]{2}{*}{$\begin{array}{l}\text { measured } \\
{ }^{207} \mathrm{~Pb} /{ }^{206} \mathrm{~Pb}\end{array}$} & \multirow[b]{2}{*}{$\begin{array}{l}\text { \%common } \\
{ }^{206} \mathrm{~Pb}\end{array}$} & \multirow[b]{2}{*}{$\begin{array}{c}\mathrm{U} \\
(\mathrm{ppm})\end{array}$} & \multirow[b]{2}{*}{$\mathrm{Th} / \mathrm{U}$} & \multicolumn{4}{|c|}{ Age (Ma) } & \multirow[b]{2}{*}{$\begin{array}{l}{ }^{207} \mathrm{~Pb} / \\
{ }^{235} \mathrm{U}^{5}\end{array}$} & \multirow[b]{2}{*}{$\begin{array}{l}\operatorname{err}^{4} \\
(\%)\end{array}$} & \multirow[b]{2}{*}{$\begin{array}{l}{ }^{206} \mathrm{~Pb} / \\
{ }^{238} \mathrm{U}^{5}\end{array}$} & \multirow[b]{2}{*}{$\begin{array}{l}\text { err }^{4} \\
(\%)\end{array}$} & \multirow[b]{2}{*}{$\begin{array}{l}\text { err. } \\
\text { corr. }\end{array}$} \\
\hline & & & & & & $\begin{array}{l}{ }^{206} \mathrm{~Pb} / \\
{ }^{238} \mathrm{U}^{2}\end{array}$ & $\mathrm{err}^{4}$ & $\begin{array}{l}{ }^{207} \mathrm{~Pb} / \\
{ }^{206} \mathrm{~Pb}^{2,3}\end{array}$ & $\operatorname{err}^{4}$ & & & & & \\
\hline Ma1-12-75.1 & 0.000030 & 0.0558 & 0.055 & 692 & 1.27 & 432 & 5 & & & 0.53 & 1.9 & 0.069 & 1.3 & 0.7 \\
\hline Ma1-12-76.1 & 0 & 0.0575 & 0 & 876 & 0.27 & 474 & 4 & & & 0.60 & 1.2 & 0.076 & 0.8 & 0.7 \\
\hline \multicolumn{15}{|c|}{ Madrid Formation (MA) : MA-2 Alder Brook quadrangle, UTM Location 0575363E/50687765N } \\
\hline UNSS-1-12-1.1 & 0.000087 & 0.1017 & 0.160 & 171 & 0.38 & 1611 & 14 & 1633 & 18 & 3.9 & 1.4 & 0.284 & 1.0 & 0.7 \\
\hline UNSS-1-12-2.1 & 0.000019 & 0.0885 & 0.035 & 925 & 0.81 & 1366 & 11 & 1387 & 9 & 2.9 & 1.0 & 0.236 & 0.9 & 0.9 \\
\hline UNSS-1-12-3.1 & --- & 0.1032 & 0 & 199 & 0.75 & 1643 & 13 & 1683 & 15 & 4.1 & 1.2 & 0.290 & 0.9 & 0.8 \\
\hline UNSS-1-12-4.1 & 0.000083 & 0.0817 & 0.151 & 32 & 1.17 & 1316 & 23 & 1210 & 57 & 2.5 & 3.5 & 0.226 & 1.9 & 0.6 \\
\hline UNSS-1-12-5.1 & 0.000028 & 0747 & 0.050 & 209 & 0.38 & 991 & 9 & 1050 & 23 & 1.7 & 1.5 & 0.166 & 1.0 & 0.6 \\
\hline UNSS-1-12-6.1 & 0.000011 & 0.0916 & 0.021 & 402 & 0.28 & 1412 & 19 & 1455 & 12 & 3.1 & 1.6 & 0.245 & 1.5 & 0.9 \\
\hline UNSS-1-12-7.1 & -0.000030 & 0.0695 & -0.055 & 263 & 0.32 & 890 & 7 & & & 1.4 & 1.5 & 0.148 & 0.9 & 0.6 \\
\hline UNSS-1-12-8.1 & .000011 & 8861 & 0.020 & 205 & 0.64 & 1308 & 22 & 1337 & 17 & 2.7 & 2.1 & 0.225 & 1.9 & 0.9 \\
\hline UNSS-1-12-9.1 & -0.000011 & 0933 & -0.020 & 177 & 0.27 & 1531 & 13 & 1497 & 50 & 3.5 & 2.8 & 0.268 & 0.9 & 0.3 \\
\hline UNSS-1-12-10.1 & 0.000011 & 0727 & 021 & 2892 & 0.05 & 950 & 5 & 1002 & 14 & 1.6 & 0.9 & 0.159 & 0.6 & 0.7 \\
\hline UNSS-1-12-11.1 & -0.000113 & 0.0704 & -0.206 & 34 & 3.96 & 984 & 17 & & & 1.6 & 4.2 & 0.165 & 1.9 & 0.4 \\
\hline UNSS-1-12-12.1 & -0.000072 & 0.0580 & -0.132 & 219 & 0.82 & 452 & 4 & & & 0.6 & 2.4 & 0.073 & 1.0 & 0.4 \\
\hline UNSS-1-12-13.1 & 0.000012 & 0.0744 & 0.021 & 756 & 0.31 & 1049 & 16 & 1047 & 10 & 1.8 & 1.7 & 0.177 & 1.7 & 1.0 \\
\hline UNSS-1-12-14.1 & 000013 & 734 & 23 & 243 & 1.27 & 962 & 7 & 1019 & 21 & 1.6 & 1.3 & 0.161 & 0.8 & 0.6 \\
\hline UNSS-1-12-15.1 & .000030 & 3 & & 133 & 1.13 & 1759 & 22 & 1764 & 5 & 4.7 & 1.4 & 0.314 & 1.4 & 1.0 \\
\hline UNSS-1-12-16.1 & 0.000050 & 0.0729 & 0.092 & 153 & 0.66 & 995 & 9 & & & 1.7 & 1.9 & 0.167 & 1.0 & 0.5 \\
\hline UNSS-1-12-17.1 & -0.000014 & 0.0564 & -0.025 & 469 & 0.76 & 471 & 3 & & & 0.6 & 1.4 & 0.076 & 0.7 & 0.5 \\
\hline UNSS-1-12-18.1 & 0.000008 & 0.0774 & 0.015 & 1008 & 0.17 & 1063 & 19 & 1128 & 8 & 1.9 & 2.0 & 0.179 & 1.9 & 1.0 \\
\hline UNSS-1-1 & 006 & & 11 & & 0.59 & 2648 & 20 & 2725 & 8 & 13.2 & 1.1 & 0.508 & 0.9 & 0.9 \\
\hline UNSS-1-12-20.1 & 000035 & & & & 0.35 & 1405 & 28 & 144 & 22 & 3.1 & 2.5 & 0.243 & 3 & 0.9 \\
\hline UNSS-1-12-21.1 & 0.000024 & 0.0739 & 0.044 & 243 & 0.19 & 1004 & 16 & 1031 & 21 & 1.7 & 2.0 & 0.168 & 1.7 & 0.9 \\
\hline UNSS-1-12-22.1 & 0.000014 & 0750 & 0.026 & 369 & 0.58 & 1041 & 14 & 1064 & 16 & 1.8 & 1.7 & 0.175 & 1.5 & 0.9 \\
\hline UNSS-1-12-23.1 & 0 & 995 & 0 & 216 & 0.97 & 1580 & 14 & 1614 & 14 & 3.8 & 1.2 & 0.278 & 1.0 & 0.8 \\
\hline UNSS-1-12-24.1 & 0.000488 & & 892 & & 0.62 & 469 & 7 & & & 0.6 & 2.8 & 0.075 & 1.5 & 0.6 \\
\hline UNSS-1-12-25.1 & 0.000023 & & 0.042 & & 0.73 & 1620 & 12 & 1639 & 13 & 4.0 & 1.1 & 0.286 & 0.8 & 0.8 \\
\hline UNSS-1-12-26.1 & 0 & 0758 & 0 & 233 & 0.61 & 1053 & 15 & 1091 & 19 & 1.9 & 1.8 & 0.177 & 1.5 & 0.8 \\
\hline UNSS-1-12-27.1 & .000028 & 0847 & 051 & 91 & 0.5 & 1220 & 23 & 1300 & 29 & 2.4 & 2.5 & 0.208 & 2.1 & 0.8 \\
\hline UNSS-1-12-28.1 & 0.000047 & 0578 & 0.085 & 172 & 0.82 & 443 & 4 & & & 0.6 & 4.3 & 0.071 & 1.0 & 0.2 \\
\hline UNSS-1-12-29.1 & 0.000020 & 574 & 0.037 & 14 & 0.76 & 474 & 4 & & & 0.6 & 1.7 & 0.076 & 0.8 & 0.5 \\
\hline UNSS-1-12-30.1 & --- & 1867 & 0 & 208 & 0.65 & 2734 & 23 & 2713 & 8 & 13.6 & 1.1 & 0.528 & 1.0 & 0.9 \\
\hline UNSS-1-12-31.1 & -0.000020 & & -0.036 & & 0.42 & 1033 & 10 & 1063 & 26 & 1.8 & 1.7 & 0.174 & 1.1 & 0.6 \\
\hline UNSS-1-12-32.1 & 0.000009 & .0884 & 0.017 & 927 & 0.27 & 1283 & 17 & 1388 & 8 & 2.7 & 1.5 & 0.220 & 1.5 & 1.0 \\
\hline UNSS-1-12-33.1 & 0.000027 & 0.0554 & 0.050 & 590 & 0.64 & 426 & 5 & & & 0.5 & 1.8 & 0.068 & 1.2 & 0.7 \\
\hline UNSS-1-12-34.1 & 000154 & 570 & 282 & 198 & 1.11 & 440 & 4 & & & 0.5 & 3.5 & 0.071 & 1.0 & 0.3 \\
\hline UNSS-1-12-35.1 & .000009 & 0.1035 & 0.016 & 251 & 0.8 & 1730 & 14 & 1685 & 14 & 4.4 & 1.2 & 0.308 & 0.9 & 0.8 \\
\hline UNSS-1-12-36.1 & .000059 & 0.0550 & 0.108 & 378 & 0.91 & 454 & 10 & & & 0.5 & 3.1 & 0.073 & 2.3 & 0.7 \\
\hline UNSS-1-12-37.1 & 0.000028 & 0.0923 & 0.050 & 233 & 0.17 & 1511 & 12 & 1465 & 16 & 3.3 & 1.2 & 0.264 & 0.9 & 0.7 \\
\hline UNSS-1-12-38.1 & 0.000028 & 0.1026 & 0.052 & 343 & 1.76 & 1665 & 13 & 1665 & 15 & 4.2 & 1.2 & 0.295 & 0.9 & 0.8 \\
\hline UNSS-1-12-39.1 & -0.000005 & 1006 & -0.009 & 438 & 0.61 & 1609 & 11 & 1637 & 10 & 3.9 & 0.9 & 0.283 & 0.8 & 0.8 \\
\hline UNSS-1-12-40.1 & -0.000045 & 0.0550 & -0.082 & 320 & 0.44 & 431 & 4 & & & 0.5 & 2.6 & 0.069 & 0.9 & 0.4 \\
\hline UNSS-1-12-41.1 & 0.000018 & 0.1024 & 0.033 & 158 & 0.85 & 1721 & 17 & 1664 & 20 & 4.3 & 1.6 & 0.306 & 1.1 & 0.7 \\
\hline UNSS-1-12-42.1 & -0.000008 & 0.1895 & -0.014 & 231 & 0.86 & 2759 & 23 & 2738 & 9 & 14.0 & 1.2 & 0.534 & 1.0 & 0.9 \\
\hline UNSS-1-12-43.1 & 0.000010 & 0.1703 & 0.019 & 174 & 1.34 & 2502 & 23 & 2560 & 11 & 11.1 & 1.3 & 0.474 & 1.1 & 0.9 \\
\hline UNSS-1-12-44.1 & 0.000061 & 0.0979 & 0.111 & 102 & 0.78 & 1487 & 17 & 1569 & 61 & 3.5 & 3.5 & 0.259 & 1.3 & 0.4 \\
\hline UNSS-1-12-45.1 & 0.000076 & 0.0555 & 0.139 & 323 & 0.34 & 442 & 5 & & & 0.5 & 2.4 & 0.071 & 1.2 & 0.5 \\
\hline UNSS-1-12-46.1 & 0.000018 & 0.1018 & 0.033 & 166 & 0.62 & 1634 & 16 & 1653 & 20 & 4.0 & 1.5 & 0.288 & 1.1 & 0.7 \\
\hline
\end{tabular}


Appendix C: Continued.

\begin{tabular}{|c|c|c|c|c|c|c|c|c|c|c|c|c|c|c|}
\hline \multirow[b]{2}{*}{ sample $^{1}$} & \multirow[b]{2}{*}{$\begin{array}{l}\text { measured } \\
{ }^{204} \mathrm{~Pb} /{ }^{206} \mathrm{~Pb}\end{array}$} & \multirow[b]{2}{*}{$\begin{array}{l}\text { measured } \\
{ }^{207} \mathrm{~Pb} /{ }^{206} \mathrm{~Pb}\end{array}$} & \multirow[b]{2}{*}{$\begin{array}{l}\text { \%common } \\
{ }^{206} \mathrm{~Pb}\end{array}$} & \multirow[b]{2}{*}{$\begin{array}{c}\mathrm{U} \\
(\mathrm{ppm})\end{array}$} & \multirow[b]{2}{*}{$\mathrm{Th} / \mathrm{U}$} & \multicolumn{4}{|c|}{ Age (Ma) } & \multirow[b]{2}{*}{$\begin{array}{l}{ }^{207} \mathrm{~Pb} / \\
{ }^{235} \mathrm{U}^{5}\end{array}$} & \multirow[b]{2}{*}{$\begin{array}{l}\text { err }^{4} \\
(\%)\end{array}$} & \multirow[b]{2}{*}{$\begin{array}{l}{ }^{206} \mathrm{~Pb} / \\
{ }^{238} \mathrm{U}^{5}\end{array}$} & \multirow[b]{2}{*}{$\begin{array}{l}\mathrm{err}^{4} \\
(\%)\end{array}$} & \multirow[b]{2}{*}{$\begin{array}{l}\text { err. } \\
\text { corr. }\end{array}$} \\
\hline & & & & & & $\begin{array}{l}{ }^{206} \mathrm{~Pb} / \\
{ }^{238} \mathrm{U}^{2}\end{array}$ & $\mathrm{err}^{4}$ & $\begin{array}{l}{ }^{207} \mathrm{~Pb} / \\
{ }^{206} \mathrm{~Pb}^{2,3}\end{array}$ & $\mathrm{err}^{4}$ & & & & & \\
\hline UNSS-1-12-47.1 & 0.000017 & 0.1874 & 0.031 & 68 & 1.07 & 2711 & 30 & 2717 & 13 & 13.5 & 1.6 & 0.523 & 1.4 & 0.9 \\
\hline UNSS-1-12-48.1 & -0.00012 & 0.0557 & -0.220 & 136 & 0.09 & 488 & 5 & & & 0.6 & 3.4 & 0.079 & 1.1 & 0.3 \\
\hline UNSS-1-12-49.1 & -0.000019 & 0.1957 & -0.034 & 135 & 0.81 & 2794 & 25 & 2793 & 10 & 14.7 & 1.3 & 0.543 & 1.1 & 0.9 \\
\hline UNSS-1-12-50.1 & --- & 0.0863 & 0 & 80 & 0.64 & 1351 & 18 & 1346 & 35 & 2.8 & 2.3 & 0.233 & 1.5 & 0.6 \\
\hline UNSS-1-12-51.1 & 0.000015 & 0.0860 & 0.027 & 484 & 0.5 & 1340 & 10 & 1334 & 14 & 2.7 & 1.1 & 0.231 & 0.8 & 0.7 \\
\hline UNSS-1-12-52.1 & -0.000012 & 1156 & -0.022 & 306 & 0.2 & 1909 & 14 & 1892 & 11 & 5.5 & 1.0 & 0.345 & 0.8 & 0.8 \\
\hline UNSS-1-12-53.1 & 0.000029 & 0.0881 & 0.054 & 123 & 0.53 & 1359 & 15 & 1375 & 29 & 2.8 & 1.9 & 0.235 & 1.2 & 0.6 \\
\hline UNSS-1-12-54.1 & -0.000008 & 0.1873 & -0.014 & 154 & 0.66 & 2784 & 23 & 2719 & 9 & 14.0 & 1.2 & 0.540 & 1.0 & 0.9 \\
\hline UNSS-1-12-55.1 & 0 & 0.1015 & 0 & 140 & 0.67 & 1631 & 16 & 1652 & 19 & 4.0 & 1.5 & 0.288 & 1.1 & 0.7 \\
\hline UNSS-1-12-56.1 & -0.000004 & 0.0996 & -0.008 & 478 & 0.07 & 1626 & 14 & 1618 & 9 & 3.9 & 1.1 & 0.287 & 1.0 & 0.9 \\
\hline UNSS-1-12-57.1 & 0.000066 & 0.1052 & 0.121 & 105 & 0.77 & 1653 & 18 & 1702 & 23 & 4.2 & 1.7 & 0.292 & 1.2 & 0.7 \\
\hline UNSS-1-12-58.1 & --- & 0.0724 & 0 & 108 & 0.76 & 1060 & 12 & & & 1.8 & 2.2 & 0.179 & 1.2 & 0.6 \\
\hline UNSS-1-12-59.1 & 0.000021 & 0.1080 & 0.039 & 459 & 0.13 & 1697 & 18 & 1762 & 10 & 4.5 & 1.3 & 0.301 & 1.2 & 0.9 \\
\hline UNSS-1-12-60.1 & -0.000007 & 0.0731 & -0.013 & 457 & 0.72 & 1020 & 10 & 1018 & 15 & 1.7 & 1.3 & 0.171 & 1.1 & 0.8 \\
\hline
\end{tabular}

Notes: ${ }^{1}$ All detrital zircon samples analyzed on USGS/Stanford SHRIMP-RG, Stanford University; ${ }^{206} \mathrm{~Pb} /{ }^{238} \mathrm{U}$ and ${ }^{207} \mathrm{~Pb} /{ }^{206} \mathrm{~Pb}$ ages corrected for common $\mathrm{Pb}$ using the ${ }^{204} \mathrm{~Pb}$-correction method. Decay constants from Steiger and Jäger $(1977)$; ${ }^{3}$ Not listed for ages <1.0 Ga; ${ }^{4}$ 1-sigma errors; ${ }^{5}$ Radiogenic ratios, corrected for common $\mathrm{Pb}$ using the ${ }^{204} \mathrm{~Pb}$-correction method, based on the Stacey and Kramers (1975) model. 
Appendix D. SHRIMP U-Th-Pb data for zircons from igneous rocks of eastern and east-central Maine. Location coordinates in UTM metres, (Zone 19, NAD27).

\begin{tabular}{|c|c|c|c|c|c|c|c|c|c|c|c|c|c|}
\hline \multirow[b]{2}{*}{ sample $^{1}$} & \multirow[b]{2}{*}{$\begin{array}{c}\text { measured } \\
{ }^{204} \mathrm{~Pb} /{ }^{206} \mathrm{~Pb}\end{array}$} & \multirow[b]{2}{*}{$\begin{array}{l}\text { measured } \\
{ }^{207} \mathrm{~Pb} /{ }^{206} \mathrm{~Pb}\end{array}$} & \multirow[b]{2}{*}{$\begin{array}{l}\text { \%common } \\
{ }^{206} \mathrm{~Pb}\end{array}$} & \multirow[b]{2}{*}{$\begin{array}{c}\mathrm{U} \\
(\mathrm{ppm})\end{array}$} & \multirow[b]{2}{*}{$\mathrm{Th} / \mathrm{U}$} & \multicolumn{4}{|c|}{ in $\mathrm{Ma}$} & \multirow[b]{2}{*}{$\begin{array}{l}{ }^{207} \mathrm{~Pb} / \\
{ }^{235} \mathrm{U}\end{array}$} & \multirow[b]{2}{*}{$\begin{array}{l}\mathrm{err}^{3} \\
(\%)\end{array}$} & \multirow[b]{2}{*}{$\begin{array}{c}{ }^{206} \mathrm{~Pb} / \\
{ }^{238} \mathrm{U}\end{array}$} & \multirow[b]{2}{*}{$\begin{array}{l}\mathrm{err}^{3} \\
(\%)\end{array}$} \\
\hline & & & & & & $\begin{array}{l}{ }^{206} \mathrm{~Pb} / \\
{ }^{238} \mathrm{U}^{2}\end{array}$ & $\mathrm{err}^{3}$ & $\begin{array}{c}{ }^{207} \mathrm{~Pb} / \\
{ }^{206} \mathrm{~Pb}^{2,4}\end{array}$ & $\mathrm{err}^{3}$ & & & & \\
\hline & \multicolumn{12}{|c|}{$\begin{array}{l}\text { KMV-1 Kendall Mountain Formation tuff near base of formation. Woodland quadrangle, UTM Location } \\
0623730 \mathrm{E} / 5001066 \mathrm{~N}\end{array}$} & \\
\hline KMV1-25.1 & 0.000013 & 0.0758 & 0.023 & 1633 & 0.55 & 998 & 8 & 1083 & 6 & 6.0 & 0.9 & 0.076 & 0.28 \\
\hline KMV1-1.1 & 0.001140 & 0.0744 & 2.048 & 345 & 0.78 & 474 & 5 & & & 13.1 & 1.1 & 0.058 & 3.27 \\
\hline KMV1-2.1 & -0.000010 & 0.0562 & -0.017 & 422 & 1.04 & 479 & 5 & & & 13.0 & 1.0 & 0.056 & 0.93 \\
\hline KMV1-3.1 & 0.000172 & 0.0585 & 0.310 & 133 & 0.79 & 472 & 7 & & & 13.2 & 1.5 & 0.056 & 2.43 \\
\hline KMV1-4.1 & -0.000021 & 0.0576 & -0.038 & 514 & 1.45 & 475 & 6 & & & 13.1 & 1.4 & 0.058 & 0.82 \\
\hline KMV1-5.1 & 0.000028 & 0.0589 & 0.050 & 452 & 1.26 & 470 & 9 & & & 13.2 & 1.9 & 0.058 & 0.96 \\
\hline KMV1-6.1 & 0.000003 & 0.0770 & 0.006 & 526 & 0.22 & 1077 & 9 & 1120 & 9 & 5.5 & 0.9 & 0.077 & 0.46 \\
\hline KMV1-7.1 & 0 & 0.0568 & 0 & 260 & 0.80 & 473 & 7 & & & 13.1 & 1.4 & 0.057 & 1.12 \\
\hline KMV1-8.1 & 0.000213 & 0.0599 & 0.382 & 363 & 0.75 & 472 & 8 & & & 13.2 & 1.7 & 0.057 & 1.49 \\
\hline KMV1-9.1 & 0.000023 & 0.0570 & 0.041 & 313 & 0.90 & 482 & 7 & & & 12.9 & 1.5 & 0.057 & 1.06 \\
\hline KMV1-10.1 & 0.000154 & 0.0582 & 0.278 & 278 & 0.71 & 469 & 5 & & & 13.2 & 1.1 & 0.056 & 2.47 \\
\hline KMV1-11.1 & 0.000051 & 0.0560 & 0.091 & 230 & 0.68 & 475 & 6 & & & 13.1 & 1.3 & 0.055 & 1.43 \\
\hline KMV1-12.1 & 0.000018 & 0.0799 & 0.030 & 166 & 0.27 & 1147 & 25 & 1187 & 17 & 5.1 & 2.4 & 0.080 & 0.84 \\
\hline KMV1-13.1 & 0.000002 & 0.0758 & 0.004 & 814 & 0.34 & 1096 & 18 & 1087 & 16 & 5.4 & 1.7 & 0.076 & 0.79 \\
\hline KMV1-14.1 & 0.000043 & 0.0579 & 0.078 & 272 & 1.15 & 469 & 7 & & & 13.3 & 1.6 & 0.057 & 1.30 \\
\hline KMV1-15.1 & 0.000136 & 0.0832 & 0.228 & 66 & 0.32 & 1170 & 19 & 1227 & 43 & 5.0 & 1.8 & 0.081 & 2.18 \\
\hline KMV1-16.1 & 0 & 0.0586 & 0 & 249 & 0.79 & 474 & 7 & & & 13.1 & 1.5 & 0.059 & 1.16 \\
\hline KMV1-17.1 & 0.000004 & 0.075 & 0.006 & 903 & 0.08 & 1055 & 11 & 1067 & 7 & 5.6 & 1.1 & 0.075 & 0.35 \\
\hline KMV1-18.1 & 0 & 0.0764 & 0 & 447 & 0.30 & 1076 & 14 & 1106 & 16 & 5.5 & 1.5 & 0.076 & 0.80 \\
\hline KMV1-19.1 & -0.000007 & 0.0572 & -0.012 & 586 & 1.35 & 480 & 6 & & & 12.9 & 1.2 & 0.057 & 0.78 \\
\hline KMV1-20.1 & -0.000141 & 0.0564 & -0.253 & 118 & 0.57 & 476 & 8 & & & 13.0 & 1.8 & 0.058 & 2.43 \\
\hline KMV1-21.1 & 0.000013 & 0.0573 & 0.023 & 295 & 0.88 & 483 & 4 & & & 12.9 & 1.0 & 0.057 & 1.09 \\
\hline KMV1-22.1 & 0.000017 & 0.0574 & 0.031 & 270 & 0.76 & 484 & 6 & & & 12.8 & 1.3 & 0.057 & 1.26 \\
\hline & 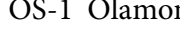 & & 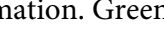 & & & 促 & & 20 & & . & & & \\
\hline 13A78-1.1 & 0.000780 & 0.0577 & 1.402 & 55 & 0.63 & 462 & 9 & & & 13.4 & 2.1 & 0.046 & 16.0 \\
\hline $13 \mathrm{~A} 78-2.1$ & 0.000281 & 0.0597 & 0.495 & 70 & 2.2 & 662 & 10 & & & 9.2 & 1.7 & 0.056 & 6.6 \\
\hline 13A78-3.1 & 0.000799 & 0.0553 & 1.437 & 56 & 0.61 & 460 & 8 & & & 13.5 & 1.8 & 0.043 & 16.8 \\
\hline $13 \mathrm{~A} 78-4.1$ & -0.000059 & 0.0572 & -0.107 & 55 & 0.61 & 471 & 7 & & & 13.2 & 1.6 & 0.058 & 5.3 \\
\hline $13 \mathrm{~A} 78-5.1$ & 0.000430 & 0.0579 & 0.772 & 57 & 0.64 & 462 & 10 & & & 13.5 & 2.3 & 0.052 & 10.0 \\
\hline $13 \mathrm{~A} 78-6.1$ & -0.000145 & 0.0577 & -0.261 & 68 & 0.63 & 460 & 16 & & & 13.5 & 3.5 & 0.060 & 5.8 \\
\hline $13 \mathrm{~A} 78-7.1$ & -0.000101 & 0.0593 & -0.181 & 64 & 0.63 & 481 & 8 & & & 12.9 & 1.6 & 0.061 & 4.3 \\
\hline $13 \mathrm{~A} 78-8.1$ & 0.000209 & 0.0584 & 0.375 & 71 & 0.67 & 459 & 7 & & & 13.5 & 1.6 & 0.055 & 6.6 \\
\hline 13 A78-9.1 & 0.000045 & 0.0563 & 0.081 & 71 & 0.65 & 473 & 8 & & & 13.1 & 1.8 & 0.056 & 3.3 \\
\hline $13 \mathrm{~A} 78-10.1$ & 0.000284 & 0.0574 & 0.510 & 81 & 1.1 & 483 & 8 & & & 12.8 & 1.8 & 0.053 & 7.5 \\
\hline $13 \mathrm{~A} 78-11.1$ & 0.000052 & 0.0574 & 0.093 & 61 & 0.63 & 469 & 10 & & & 13.3 & 2.1 & 0.057 & 3.7 \\
\hline $13 \mathrm{~A} 78-12.1$ & 0.000388 & 0.0599 & 0.692 & 102 & 0.77 & 549 & 11 & & & 11.3 & 2.2 & 0.054 & 8.6 \\
\hline $13 \mathrm{~A} 78-13.1$ & 0.000086 & 0.0575 & 0.155 & 74 & 0.68 & 472 & 9 & & & 13.2 & 1.9 & 0.056 & 4.1 \\
\hline 13A78-14.1 & -0.000152 & 0.0560 & -0.274 & 62 & 0.63 & 460 & 10 & & & 13.5 & 2.3 & 0.058 & 5.3 \\
\hline 13A78-15.1 & -0.000156 & 0.0581 & -0.280 & 64 & 0.63 & 468 & 10 & & & 13.3 & 2.3 & 0.060 & 6.2 \\
\hline $13 \mathrm{~A} 78-16.1$ & -0.000050 & 0.0587 & -0.090 & 73 & 0.65 & 461 & 7 & & & 13.5 & 1.6 & 0.059 & 3.4 \\
\hline 13A78-17.1 & 0.000213 & 0.0572 & 0.381 & 82 & 0.75 & 497 & 15 & & & 12.5 & 3.2 & 0.054 & 6.9 \\
\hline
\end{tabular}

PM Pocomoonshine gabbro-diorite, near northern margin. Princeton quadrangle, UTM Location 0612829E/5002319N

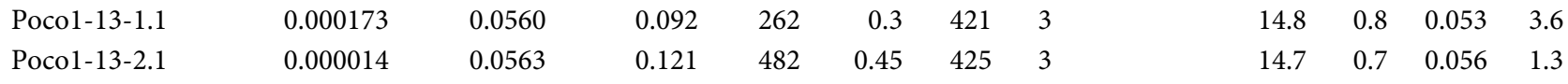


Appendix D. Continued.

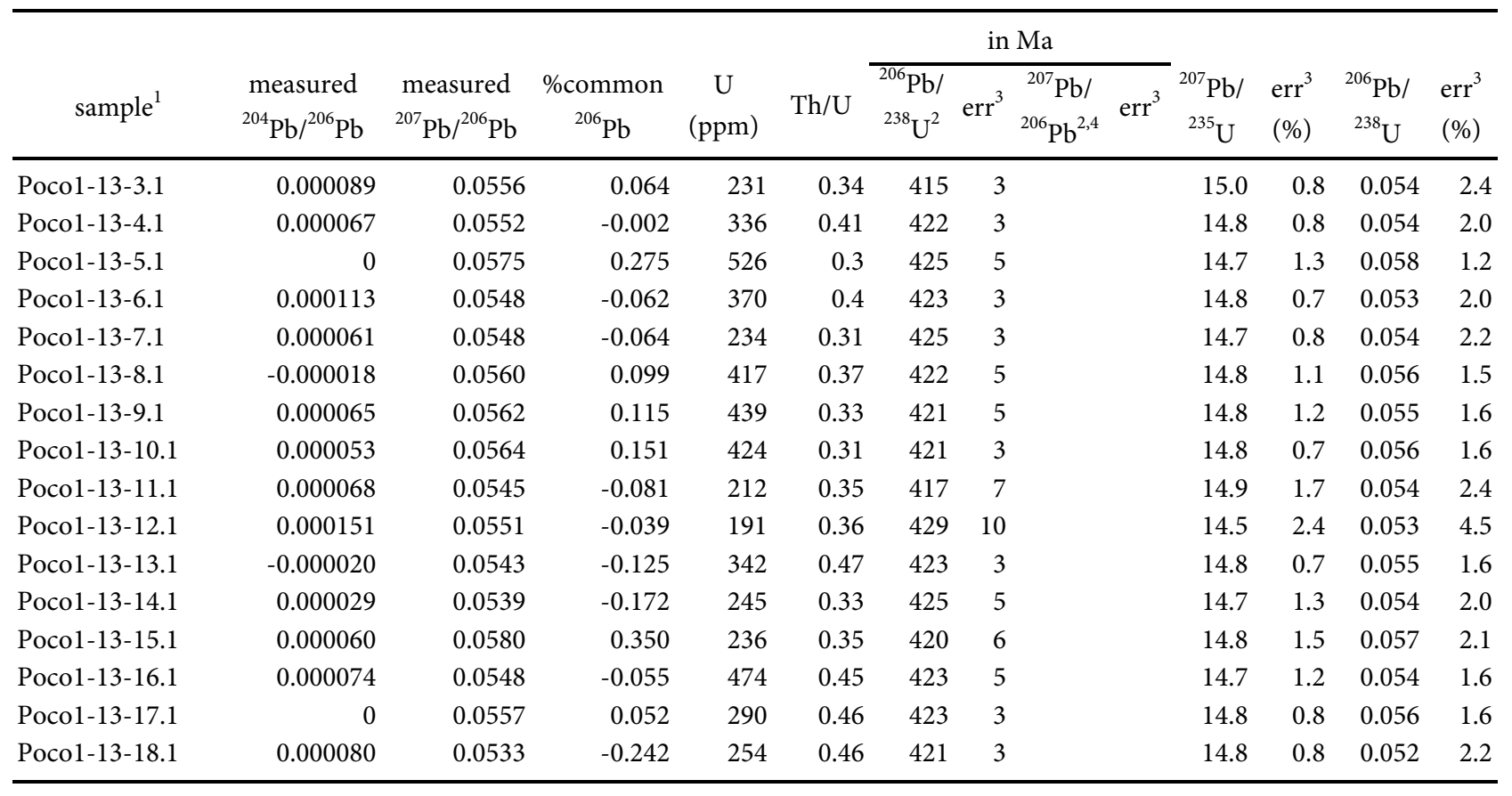

Notes: ${ }^{1}$ All detrital zircon samples analyzed on USGS/Stanford SHRIMP-RG, Stanford University; ${ }^{206} \mathrm{~Pb} /{ }^{238} \mathrm{U}$ and ${ }^{207} \mathrm{~Pb} /{ }^{206} \mathrm{~Pb}$ ages corrected for common $\mathrm{Pb}$ using the ${ }^{204} \mathrm{~Pb}$-correction method. Decay constants from Steiger and Jäger (1977); ${ }^{3} 1$-sigma errors; ${ }^{4}$ Listed only for ages $>1.0 \mathrm{Ga}$. 